\title{
EVALUATION OF SLURRY INJECTION TECHNOLOGY FOR MANAGEMENT OF DRILLING WASTES
}

\author{
JOHN A. VEIL AND \\ MAURICE B. DUSSEAULT \\ ARGONNE NATIONAL LABORATORY
}

\author{
PREPARED FOR: \\ U.S. DEPARTMENT OF ENERGY
}

National Petroleum Technology Office UNDER CONTRACT W-3 1-1 09-ENG-38

MAY 2003 


\section{TABLE OF CONTENTS}

Executive Summary

Chapter 1 - Introduction

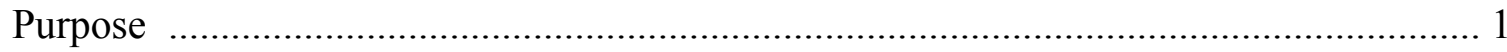

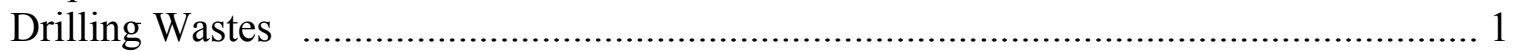

Management of Drilling Wastes .......................................................................... 8

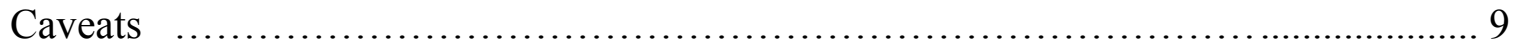

Chapter 2 - Underground Injection of Drilling Wastes ..........................................................11

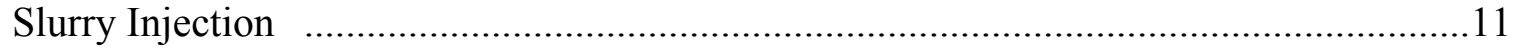

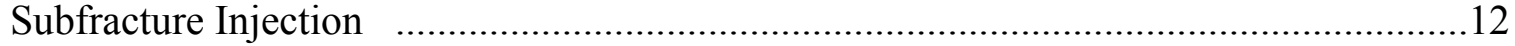

Plugging and Abandonment ………………………........................................12

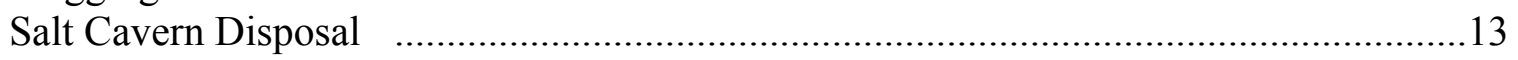

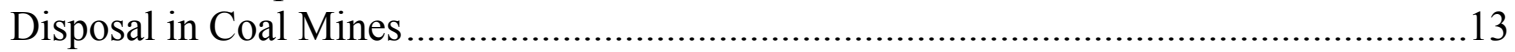

Chapter 3 - Slurry Injection Technology ………..............................................................14

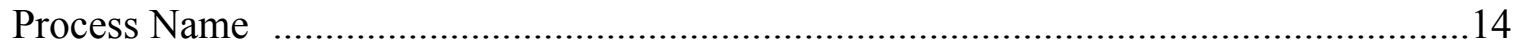

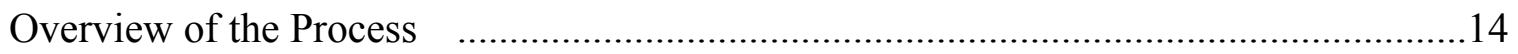

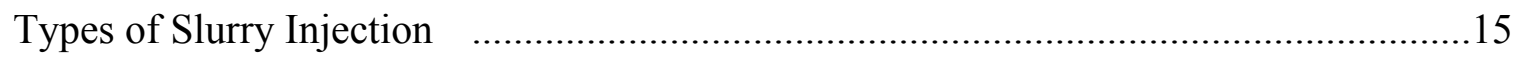

Solids Handling and Preparation of the Slurry …………............................................16

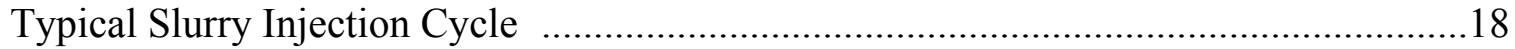

Long-Term Injection Processes ………………………........................................ 22

Slurry Injection of Wastes Other Than Drilling Wastes ................................................23

Feasibility of Slurry Injection Technology ......................................................................24

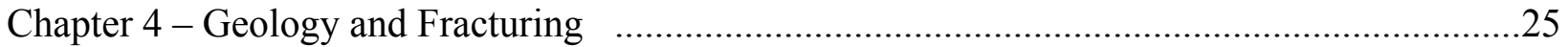

Desirable Characteristics for Injection Formations ……….........................................25

Introduction to Fracturing ………………………….............................................2.

Fracture Growth and Shape …………………………........................................2

Prediction of Fracture Geometry ……………………............................................29

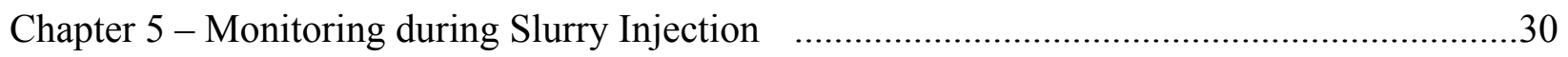

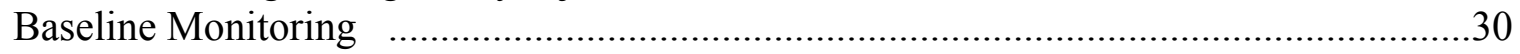

Logging Methods Applicable to Slurry Injection ………............................................31

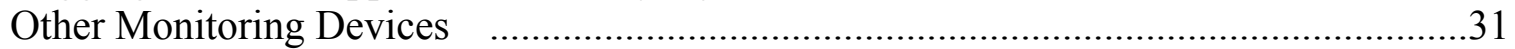

Deep Well Treatment and Injection Program ……………..............................................33

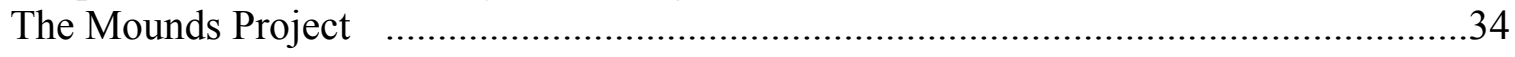

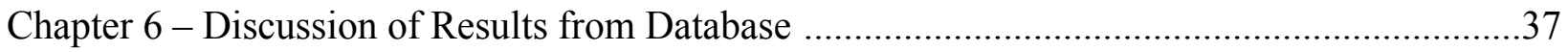

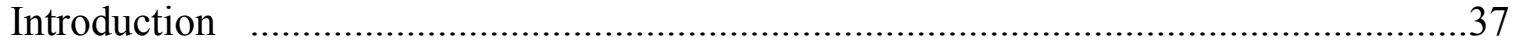

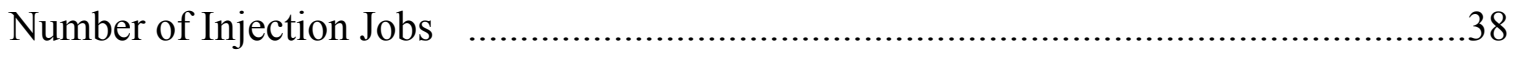

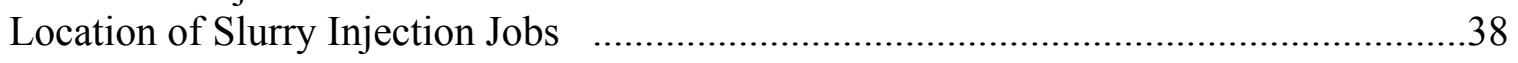




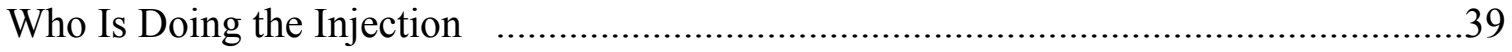

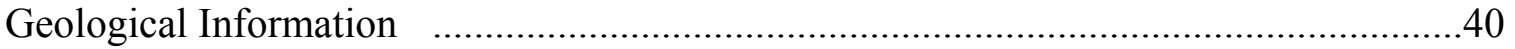

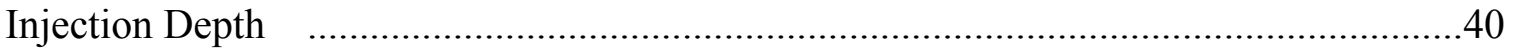

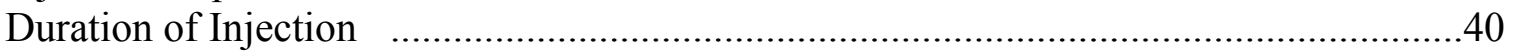

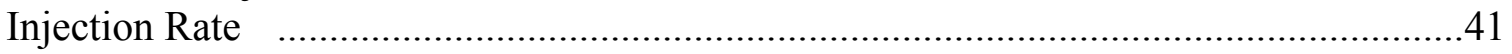

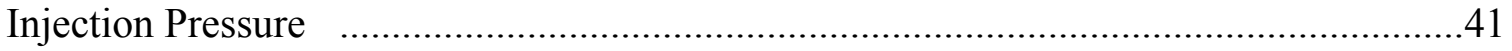

Type and Volume of Material Injected

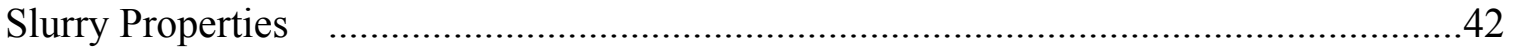

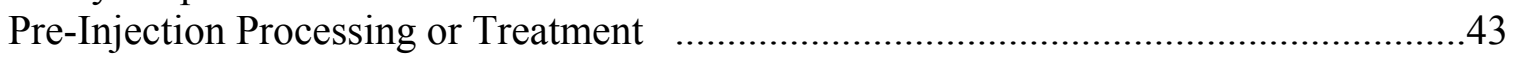

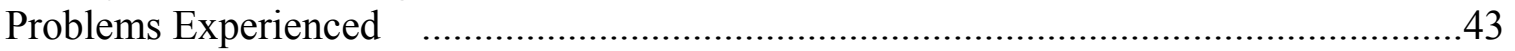

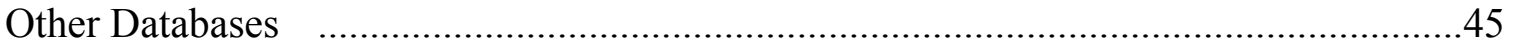

Chapter 7 - Economic Considerations ............................................................................46

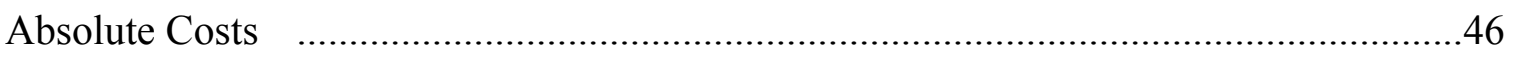

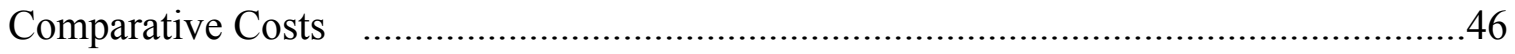

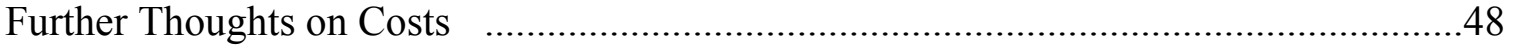

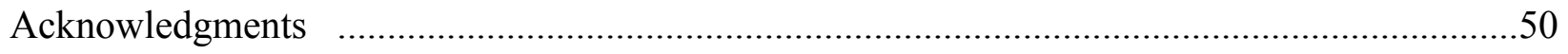

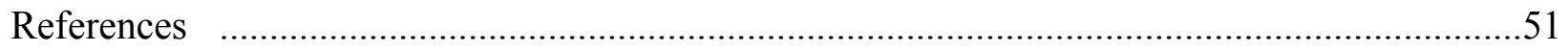

Figures

Figure 1: Annular Injection into Wells with Multiple Casing Strings

Figure 2: Injection into Dedicated Injection Well

Figure 3: Pressure vs. Time Plot for Two Daily Cycles of Slurry Injection

Figure 4: Long-Term Solids Injection Approach

Figure 5: Screening out of Injected Particles at Fracture Tip

Figure 6: Stress Definition and Fracture Orientations

Figure 7: Series of Vertical Plane Fractures with Different Azimuths Depicting the Disposal Domain Concept

Appendix A: Data on Waste Injection Events 


\section{EXECUTIVE SUMMARY}

Each year, thousands of new oil and gas wells are drilled in the United States and around the world. The drilling process generates millions of barrels of drilling waste each year, primarily used drilling fluids (also known as muds) and drill cuttings. The drilling wastes from most onshore U.S. wells are disposed of by removing the liquids from the drilling or reserve pits and then burying the remaining solids in place (called pit burial). This practice has low cost and the approval of most regulatory agencies. However, there are some environmental settings in which pit burial is not allowed, such as areas with high water tables. In the U.S. offshore environment, many water-based and synthetic-based muds and cuttings can be discharged to the ocean if discharge permit requirements are met, but oil-based muds cannot be discharged at all. At some offshore facilities, drilling wastes must be either hauled back to shore for disposal or disposed of onsite through an injection process.

\section{Underground Injection of Drilling Wastes}

This report describes several ways in which drilling wastes have been injected into underground formations for permanent disposal. Examples of these methods include waste injection into salt caverns, injection during plugging and abandonment of wells, injection to formations at pressures lower than the formation's fracture pressure (subfracture injection), and injection at pressures exceeding the fracture pressure (referred to as slurry injection in this report). The report focuses on slurry injection technology, how it is conducted and monitored, the geological conditions that favor slurry injection, and its costs. A database describing more than 330 actual slurry injection jobs is included as an appendix to this report. The following paragraphs summarize the report's findings.

\section{Slurry Injection Technology}

Slurry injection involves processing solid materials to make particles of suitable size and blending them with a fluid (often seawater, collected stormwater, other fresh water, used drilling muds, or produced water, as approved by the regulatory agency) to create a slurry. The slurry is injected into a suitable confined formation at a pressure high enough to continuously fracture the formation receiving the slurry. When injection ceases, the pressure declines as the fluid bleeds off into the formation, and the solids are trapped in place in the induced fractures. The most common forms of slurry injection involve: (1) annular injection, in which the waste slurry is injected through the annular space between two casing strings into the receiving strata, and (2) a dedicated disposal well, completed with tubing and packer giving access to either an open hole or a perforated casing interval at the depth of an injection formation. The casing must be cemented below, through, and above the proposed injection zone to ensure the waste is confined to the intended receiving zone. Figures 1 and 2 are schematic drawings of the two slurry injection types. 
Slurry injection can be conducted as a single continuous process or as a series of smaller-volume intermittent cycles. On some offshore platforms, where drilling occurs continuously and storage space is inadequate to operate in a daily batch manner, injection must occur continuously as new wells are drilled. In these cases, injection pressures are carefully monitored so operators can be aware of changes in formation injectivity and identify incipient problems. Most other injection jobs are designed to inject intermittently (i.e., inject for several hours each day, allow the injected fluids to dissipate into the formation overnight, and then repeat the cycle on the following day or a few days later). Figure 3 shows two daily injection cycles. The frequency of intermittent injection cycles is dependent on the rate of drilling waste generation. The intermittent approach can help to induce new fractures each day rather than lengthening the original fracture. This approach minimizes the likelihood that fractures will extend outside of the targeted formation and may allow for fracture storage of a larger volume of solid material.

Many annular injection jobs are designed to receive wastes from just one well. On multiwell platforms or onshore well pads, the first well drilled may receive wastes from the second well. Each successive well has its drilling wastes injected into previously drilled wells. In this mode, no single injection well is used for more than a few weeks or months. Other injection programs, particularly those in which a dedicated injection well has been constructed, may operate for months to years.

Although most slurry injection jobs are used to inject drilling wastes, various other oil field wastes have also been disposed in this manner. The report describes literature accounts of injection of produced sands, tank bottoms, oily wastewater, pit contents, naturally occurring radioactive material (NORM), produced water, oily sand, seawater, brine, sewage, crude oil, spent acid, diesel, contaminated snow, methanol, line pigging wastes, boiler water, sulfur slurry that is produced during processing of gas and condensates, mercury-contaminated sludge, and soil contaminated by crude oil spills.

\section{Geology and Fracturing}

Most annular injection jobs inject into shales or other low-permeability formation. However, the vertical section of formation between the shoe of the outer casing and the top of cement behind the inner casing may include a lengthy sequence of sands or other high permeability layers located not far below the casing shoe, which can affect slurry injection. Most dedicated injection wells inject into high-permeability sand layers. Regardless of which type of rock is selected for the injection formation, preferred sites will be overlain by formations having the opposite permeability characteristics (high vs. low). When available, alternating sequences of sand and shales are good candidates, with injection taking place into one of the lower layers, so that the upper layers serve both as containment barriers (low permeability) and rapid leak off zones (high permeability) to arrest upward fracture growth. In the absence of such a sequence of sand and shales, annular injection may not be good candidate technology for waste disposal.

An optimal target formation will be thick, relatively level, and extend for a large distance laterally. A larger formation, in both vertical and lateral extent, will be able to store a greater quantity of waste material and will also dissipate injection pressures more effectively. Slurry 
injection jobs should be designed to ensure that fracturing does not allow fluids to migrate to drinking water aquifers, the ground surface, or the sea floor (for offshore locations). Therefore, the target formations should not be located too close to the surface or to sensitive aquifers and should be vertically separated from them by appropriate barriers. Likewise, fractures induced by waste injection should not interfere with formations that are currently producing oil and gas or that may be used for production in the future. Some geological features that could allow undesirable injection consequences include faults, local seismic activity, overlying rocks that are intensely naturally fractured, and steeply dipping formations. Injection into such areas should be avoided or executed only with particularly care and conservatism.

Slurry injection relies on fracturing of the receiving formation, unlike subfracture injection, which is conducted below fracture pressure. The oil and gas industry has more than half a century of experience with fracturing producing formations to stimulate additional production. The process of fracturing involves pumping a fluid into a formation at a rate and pressure that exceed the formation's ability to assimilate the fluid into the rock matrix, therefore the injection pressure must rise. At some point, the rock cracks or fractures in response to the elevated pressures. Depending on the pressure, fluid properties, volume of injected fluid, and length of time the high pressure is applied, the fracture will grow to various lengths and will follow different geometries that are functions of local lithostratigraphy and stresses in the rock layers. The lessons learned from fracturing formations to stimulate production can be applied to slurry injection of wastes.

The mechanics of hydraulically induced fracturing in the earth dictate that fractures will almost always propagate in a direction perpendicular to the direction of least stress. At typical slurry injection depths (generally several thousand feet) and conditions, the fracture resulting from a single injection episode assumes the shape of a single vertical plane. If pressure is continuously kept on the formation, the fracture will continue to grow vertically and horizontally away from the point of injection (Figure 6). However, when injection of slurried wastes is conducted in an intermittent fashion and the formation is allowed to rest after each injection cycle, evidence suggests that a more complicated fracture pattern - the disposal domain - is formed (Figure 7). Subsequent injection cycles would be expected to generate a series of vertical fractures of similar size that have slightly different azimuths (angles around the well bore). Also, as more and more solids are placed into the receiving formation, the fractures will increasingly have components of horizontal fracture orientation. The report describes a variety of numerical models that have been used to predict the geometry of fractures from conventional hydraulic fracturing programs and from slurry injection jobs.

The disposal domain concept suggests that the volume of waste that can be accommodated in a zone near the injection well bore is far larger than what might be predicted by a conventional model or numerical simulation. Instead of disposal taking place in a single planar fracture, the waste materials can be disposed of into numerous sequentially generated fractures. An additional advantage of multiple small fractures over a single large fracture is that no one fracture is likely to grow so high vertically that it may intersect aquifers or surface features, or laterally so that it may interfere with other well bores located some distance away. 


\section{Monitoring During Slurry Injection}

A variety of tools exists for monitoring the size and shape of the fractures. Conventional well bore logging methods (radioactive tracers, temperature logs, and imaging logs) provide some indication of fracture position, but are severely limited in their capacity to give useful information about fracture geometry and extent because the radius of investigation is only a few feet at best. External devices that measure an induced response and are located at the surface or in monitoring wells provide much better information. Induced responses include, for example, the deformation field, microseismic activity, or even changes in an electrical potential field measured through electrodes. Examples of sensors for these fields include tiltmeters for deformations and geophones for microseismic event monitoring. Hydraulic impedance testing has provided useful fracture information in some injection jobs.

The report describes two injection research programs in which materials were injected under highly controlled and monitored conditions. The Deep Well Treatment and Injection Program was conducted by ARCO in Texas in 1993, and an even more ambitious program was undertaken by a consortium of researchers at Mounds, Oklahoma, in 1998. The results of the Mounds test confirmed that intermittent injections create multiple fractures, thereby supporting the disposal domain concept. Both research programs contributed to a better understanding of fracture formation and interpretation of monitoring results.

\section{The Slurry Injection Database}

The slurry injection database contains full or partial information on 334 injection jobs from around the world. The information was distilled from numerous published articles and papers, from unpublished reports, and from data supplied directly by several producers, service companies, and a regulatory agency. The three leading areas in which slurry injection is represented in the database are Alaska (129 records), Gulf of Mexico (66 records), and the North Sea (35 records). There are far more total wells in the Gulf of Mexico than in the other two areas so that the actual proportion of slurry injection jobs for Gulf of Mexico wells is probably much lower than for the other two areas. Slurry injection is being carried out primarily on wells owned by many large multinational companies, but some injection also is being done by medium or large independent companies. Several service companies and consultants may be used by the producers in designing and conducting slurry injection operations. The details of the geology, slurry composition, and injection activities are further described in the report.

Not all slurry injection jobs were trouble-free. Some operational problems were caused by using slurries with inappropriate viscosity, operating at too slow an injection rate, failing to clear the well bore with a clean water flush at the end of an injection cycle, and allowing pressure to drop at the end of an injection cycle so that solids could flow back into the well bore from the formation. Another operational problem arises with excessive erosion of casing, tubing, and other components of the system caused by the abrasive nature of the slurry. In some cases, the injection was unable to keep up with the drilling rate, and cuttings had to be stockpiled. This situation is inconvenient at onshore locations but can force a stop in drilling at offshore locations when insufficient storage capacity is available. Finally, in some cases, onsite personnel added 
inappropriate materials to the waste stockpile. These materials either damaged solids processing equipment or created conditions not conducive to smooth operations.

Although the operational problems are inconvenient and costly to operators that have to stop their normal activities, the environmental problems are of much greater concern. Unanticipated leakage to the environment not only creates a liability to the operator, but it also generally results in a short-term to permanent stoppage of injection at that site. Further, whenever injection jobs result in leakage, the confidence of regulators who must approve the practice will be diminished. Several of the largest injection jobs reported have resulted in leakage. The demonstration phase of the Grind and Inject Project at Prudhoe Bay, Alaska, operated continuously for portions of 3 years. In 1997, fluids were observed broaching to the surface at multiple locations near the injection well. Injection was stopped, and leaked fluids were collected for disposal. The cause of the broaching was believed to be intersection of the injection plume with other nearby uncemented well bores that lead to the surface. The project demonstrated that slurry injection is effective in disposing of large volumes of drilling waste but highlighted the need for guaranteed well bore integrity. The operators of the Grind and Inject Project drilled three new dedicated injection wells designed and constructed to minimize the potential for communication of fluids. No other wells are located within 1 mile of the injection wells. Leakage can occur at offshore sites too. At the North Sea Asgard platform, several wells showed leakage at the sea floor. This leakage was presumed to be due to poor cementing jobs.

\section{Economic Considerations}

The report describes various papers from the literature that provide a range of cost comparisons between using oil-based muds and injecting the cuttings, using synthetic-based muds and discharging the cuttings, and hauling wastes to shore for disposal. Although most of the reviewed papers showed that slurry injection was the most cost-effective option at the studied site, no option was always the least costly nor was any option always the most costly. This points out the importance of conducting a site-specific cost/benefit analysis.

Three factors are critical in determining the cost-effectiveness of slurry injection: (1) The volume of material to be disposed of - the larger the volume, the more attractive injection becomes in many cases. The ability to inject onsite avoids the need to transport materials to an offsite disposal location, and transportation cost becomes important for large volumes of material. In addition, transporting large volumes of waste introduces risks associated with handling, transferring, and shipping. Transportation also consumes more fuel and generates additional air emissions. (2) The regulatory climate - the stricter the discharge requirements, the greater the likelihood that slurry injection will be cost-effective. If cuttings can be discharged at a reasonable treatment cost, then discharging is often attractive. For example, the U.S. Environmental Protection Agency (EPA) allows Gulf of Mexico operators to discharge synthetic-based cuttings as long as certain standards can be met. In the North Sea and in Alaskan waters, heavy restrictions or prohibitions have been placed on discharging synthetic-based cuttings. Regulatory requirements that prohibit or encourage slurry injection play an important role in selection of disposal options. (3) The availability of low-cost onshore disposal infrastructure - several disposal companies have established extensive networks of barge 
terminals along the Louisiana and Texas coasts to collect large volumes of wastes brought to shore from offshore Gulf of Mexico platforms. They subsequently inject them through either subfracture injection or salt cavern disposal at onshore locations. Through the economy of scale, the onshore disposal costs are not high, and much of the offshore waste that cannot be discharged is brought to shore and disposed at these facilities. Most other parts of the world do not have an effective, low-cost onshore infrastructure. Thus, in those locations, onshore disposal is often a more costly alternative.

\section{Conclusions}

In summary, slurry injection has been used successfully in many locations around the world. Although some injection jobs have not worked well, the reasons for these problems are understood and can be overcome by proper siting, design, and operation. When slurry injection is conducted at locations with suitable geological conditions and the injection process is properly monitored, slurry injection can be a very safe disposal method. Because wastes are injected deep into the earth below drinking water zones, properly managed slurry injection operations should pose lower environmental and health risks than more conventional surface disposal methods. The costs for slurry injection can be competitive or more attractive than costs for other disposal methods. Drilling waste management should be assessed for each site individually. Slurry injection will not be the favored management option for drilling wastes in all situations; however, in many locations, it compares favorably with other, more conventional, management options. 


\section{CHAPTER 1 - INTRODUCTION}

\section{Purpose}

Oil and gas wells have been drilled for more than a century. In the early years of the industry, little attention was given to environmental management of drilling wastes. Over time, state and federal regulatory requirements have become stricter, drilling and mud system technologies have advanced, and many companies have voluntarily adopted waste management options with more benign environmental impacts that those used in the past.

The U.S. Department of Energy (DOE) is responsible for ensuring an adequate and affordable supply of energy for the nation. One of DOE's goals is to identify and support technologies that help produce oil and gas at lower cost and with less environmental impact. Among DOE's interests is evaluation of promising technologies for management of drilling wastes. One such technology that has been used for more than a decade, but not frequently in the continental United States, is underground injection of drilling wastes. This report evaluates several technologies used to dispose of drilling wastes in underground formations. The report focuses on a technology referred to here as slurry injection, in which wastes are ground into fine-grained particles if necessary, mixed with a liquid to form a slurry, and then injected underground at a high enough pressure to fracture the rock formation. A related technology, subfracture injection, described in the following chapter, involves injection at pressures less than those needed to fracture the rock formation. When the injection pressure is removed, the solid particles remain trapped in the confined formation and are not in contact with ground water, nor can they react with or affect the surface biosphere.

The purpose of this report is to provide a comprehensive synthesis of the publicly available information on slurry injection technology. Currently, much information exists, but it is scattered throughout dozens of reports and papers, some of which are part of joint industry projects and therefore not available to the general public. The report describes slurry injection technology, how the process is conducted, the geological conditions that allow best performance, and the costs. An extensive database of information from more than 330 slurry injection jobs conducted around the world is included as Appendix A. The important aspect of regulatory requirements imposed by state and federal agencies on slurry injection is described in a separate companion document (Puder et al. 2002).

\section{Drilling Wastes}

A variety of oil field wastes are disposed of through injection; most notably, huge volumes of produced water are reinjected through tens of thousands of wells for enhanced recovery or disposal. Other oil field wastes that are injected at some sites include workover and completion fluids, sludges, sand, scale, contaminated soils, and stormwater, among others. The focus of this report is injection of wastes related to the drilling process. The process of drilling oil and gas wells generates two primary types of wastes - used drilling fluids and drill cuttings. Drilling fluids (also known as muds) are used to aid the drilling process; the fluid phase can be water, 
synthetic or natural oils, air, gas, or a mixture of these components. Muds are circulated through the drill bit to lubricate and cool the bit and to aid in carrying the ground-up rock particles (drill cuttings) to the surface, where the muds and cuttings are separated by mechanical means. Liquid muds are usually recycled into the mud system, which is continuously treated with various additives to maintain the desired properties for effective drilling. The solid cuttings, which are coated with mud, are stockpiled for further processing and final disposition.

Muds consist of a base fluid and various solid and liquid additives to allow for good drilling performance and control of formation fluid pressures. Some of the additives introduce potentially toxic compounds into the fluids (e.g., biocides, anticorrosion chemicals), which must be considered when the resulting wastes are managed. Most onshore wells are drilled with air, foam, water-based muds, or oil-based muds; offshore wells may also use synthetic-based muds, but they almost never use air or foam as drilling fluids. ${ }^{1}$ At the end of a drilling job, oil-based and synthetic-based muds are typically reclaimed for future use, whereas water-based muds are disposed of. Cuttings represent a significant waste that requires subsequent management. The volume of drilling wastes generated for each well that is drilled varies depending on the depth and diameter of the well bore; typically, several thousands of barrels (bbl) ${ }^{2}$ of drilling waste are generated per well. The American Petroleum Institute (API) estimates that about 150 million bbl of drilling waste were generated at U.S. onshore wells in 1995 (API 2000). This contrasts with a similar API survey conducted 10 years earlier that reported about 360 million bbl of drilling waste generated in 1985 (Wakim 1987). The reported volume of solid drilling waste (primarily cuttings) is about the same in the two reports (38 million to 39 million bbl). The largest difference was the liquid drilling wastes, which dropped from 324 million to 109 million bbl, most likely attributable to waste minimization efforts by operators. Both of these surveys were limited to U.S. onshore operations; U.S. offshore and operations and drilling in other countries contribute even more drilling waste.

\section{Management of Drilling Wastes}

A large proportion of the wells drilled at U.S. onshore locations use a recirculating drilling mud system with a reserve pit. Muds and cuttings returning from the well bore are passed through a vibrating screen (shale shaker), the liquid phase is recycled into the mud system, and the cuttings are sent to a nearby uncovered pit (reserve pit) where they accumulate throughout the drilling job. Other, low-volume, wastes are associated with drilling. Some of these are fine-grained solids that are removed from drilling fluids by desanders, desilters, and centrifuges so that the fluids can regain the desired rheological properties. There also may be cement particles that result from cementing of the casings strings in the well. The resulting fine-grained solid particles are also added to the reserve pit.

\footnotetext{
${ }^{1}$ Development documents prepared by the U.S. Environmental Protection Agency (EPA) as part of its rulemakings for oil and gas industry effluent limitations guidelines offer extensive information about the characteristics of drilling wastes (see EPA 1993 for water-based and oil-based muds and EPA 2000 for synthetic-based muds).

${ }^{2}$ A barrel is the standard unit of volume in the oil fields of the United States and many other parts of the world. An oil field barrel has a volume of 42 U.S. gallons or about 0.16 cubic meters. This report expresses volumes in barrels, or bbl.
} 
Some other types of liquid waste and surface runoff accumulate in the pit. In most locations, at the end of the drilling job, operators pump off the liquid layers for disposal through injection wells and then cover and bury the solids in place (pit burial). This is a simple, inexpensive process that has been used for decades and is acceptable to most regulatory agencies. Given the low cost of this process, there is little incentive for onshore operators in most locations to explore alternatives.

There are, however, situations in which the regulatory agencies do not permit burial of pit contents at the end of drilling, and operators must evaluate other onsite or offsite management options. Many alternative management options exist. Veil (2002) describes drilling waste management practices used in the past and the present and suggests some of the technologies or approaches that may be used in the future. An optimal waste management scheme would follow the concept of a waste management hierarchy, under which operators attempt to manage wastes in the most environmentally benign manner first, then progress to the second and third tiers of the hierarchy as necessary. In the first tier (waste minimization), processes are modified, technologies are adapted, or products are substituted so that less waste is generated. When feasible, waste minimization can often save money for operators and can result in greater protection of the environment. For those wastes that remain following waste minimization, operators next move to the second tier, in which wastes are reused or recycled. Some wastes cannot be recycled or reused and must be managed through the third tier (disposal). For some of the disposal options, wastes are treated before disposal to further reduce environmental risk.

Table 1 lists some examples of the approaches that have been used or proposed for managing drilling wastes. Some of these can be accomplished in more than one way, and there are undoubtedly other viable approaches that are not included here. Nevertheless, these examples provide a good idea of the range of management options.

\section{Caveats}

This report is intended to present an unbiased evaluation of slurry injection technology. At various places within the report, company names or products are mentioned. This in no way is intended to represent commercialism or favoritism of one company or product over another. The information is provided to more fully characterize and explain the technology.

This report is not intended to be a best practices guide. At various places in the report, actual or recommended practices based on literature reports and personal communication with practitioners in the field are described. This information is presented to help readers better understand slurry injection technology and not to endorse any particular practice.

Data reported in the slurry injection database and in the text of the report are derived from either published or unpublished literature or from information provided to Argonne by oil and gas operators, service companies, and a regulatory agency, rather than by direct measurements made by Argonne. Because Argonne has not collected the data itself, we are unable to verify its 
accuracy. Nevertheless, the data are presented to more fully describe the extent and range of slurry injection jobs that have been conducted around the world.

Finally, we acknowledge that slurry injection can be conducted in several generic ways with multiple variations on those methods. Different operators or service companies will use their own particular methodologies to accomplish the slurry injection, and different government agencies will impose varying requirements on companies conducting slurry injection. This report does not attempt to detail every possible injection system or option or explain how slurry injection may be practiced differently in all parts of the world. Rather, it endeavors to explain the main principles of slurry injection technology.

Table 1 - Examples of Drilling Waste Management Approaches

\begin{tabular}{|l|l|l|}
\hline \multicolumn{1}{|c|}{$\begin{array}{c}\text { I - Waste Minimization } \\
\text { Approaches }\end{array}$} & \multicolumn{1}{|c|}{$\begin{array}{c}\text { II - Recycle or Reuse } \\
\text { Approaches }\end{array}$} & III - Disposal Approaches \\
\hline $\begin{array}{l}\text { synthetic-based and oil-based } \\
\text { muds generate less cuttings than } \\
\text { water-based muds }\end{array}$ & $\begin{array}{l}\text { road spreading when roads } \\
\text { benefit from application of } \\
\text { waste }\end{array}$ & $\begin{array}{l}\text { land spreading or land } \\
\text { farming }\end{array}$ \\
\hline coiled tubing drilling & $\begin{array}{l}\text { reuse synthetic-based and } \\
\text { oil-based muds }\end{array}$ & road spreading \\
\hline directional/horizontal drilling & $\begin{array}{l}\text { use cleaned cuttings for fill } \\
\text { or cover material }\end{array}$ & $\begin{array}{l}\text { burial in onsite pit or offsite } \\
\text { landfill }\end{array}$ \\
\hline $\begin{array}{l}\text { use of less toxic components and } \\
\text { additives for muds }\end{array}$ & $\begin{array}{l}\text { restoration of wetlands with } \\
\text { clean cuttings }\end{array}$ & discharge to ocean \\
\hline air drilling & $\begin{array}{l}\text { use cuttings as aggregate for } \\
\text { concrete or bricks }\end{array}$ & salt cavern disposal \\
\hline & $\begin{array}{l}\text { thermal treatment with fluid } \\
\text { recovery }\end{array}$ & underground injection \\
\hline & & $\begin{array}{l}\text { thermal treatment } \\
\text { composting, vermiculture) }\end{array}$ \\
\hline
\end{tabular}




\section{CHAPTER 2 - UNDERGROUND INJECTION OF DRILLING WASTES}

Most of the produced water generated from onshore wells is disposed of through injection wells, either for enhanced recovery of oil and gas in reservoirs or for direct disposal. Both operators and regulators are familiar with this long-standing injection practice. In contrast, drilling wastes and many types of solid or semisolid oil field wastes have not routinely been managed through underground injection in most parts of the United States. One of the main purposes of this report is to describe the different ways in which drilling wastes have been injected for disposal. The following sections provide a brief overview of several injection practices. ${ }^{3}$ The practice focused upon by this report - slurry injection - is discussed in more detail in the next few chapters.

\section{Slurry Injection}

Slurry injection involves processing solid materials to make particles of suitable size (if necessary) and blending them with a fluid (often seawater, collected stormwater, other fresh water, used drilling muds, or produced water, as approved by the regulatory agency) to create a slurry. The slurry is injected into a suitable confined formation at a pressure high enough to continuously fracture the formation receiving the slurry. When injection ceases, the pressure declines as the fluid bleeds off into the formation, and the solids are trapped in place in the induced fractures. The most common forms of slurry injection involve: (1) a dedicated disposal well, completed with tubing and packer giving access to either an open hole or a perforated casing interval at the depth of an injection formation, or (2) annular injection, in which the waste slurry is injected through the annular space between two casing strings into the receiving strata. The casing must be cemented below, through, and above the proposed injection zone to ensure the waste is confined to the intended receiving zone.

Many slurry injection wells receive the cuttings from a single well (particularly in annular injection jobs) or a small number of other wells. Typically, annular injection is only allowed as a short-term event, with a permitted disposal window ranging from 30 to 120 days (Puder et al. 2002). A few specially designed dedicated injection wells have received over 1 million bbl of slurried drilling waste or other oil field wastes. For example, a slurry injection well in southern Louisiana was used to dispose of more than 1 million bbl of old drilling pit solids mixed with water into 3 million bbl of slurry. Solids were screened, ground to small and relatively uniform particle size, blended with water, and injected (Baker et al. 1999a,b; Reed et al. 2001). In another impressive example, more than 43 million bbl of slurried drilling wastes excavated from former reserve pits in the Prudhoe Bay Field on Alaska's North Slope was injected at several grind-and-inject facilities(Schmidt et al. 1999; Regg and Maunder 2003).

Slurry injection technology, initiated in the late 1980s, has been used most frequently in the United States in regions that exhibit environmental, geological, or hydrogeological circumstances that preclude the disposal of drilling wastes by burial of reserve pits. Examples of this include tundra (Alaska - Schmidt et al. 1999) or shallow water tables (coastal Louisiana Baker et al. 1999a,b; Reed et al. 2001). Slurry injection has been used extensively at offshore

\footnotetext{
${ }^{3}$ Marinello et al. (2001) also offer a good discussion of the same types of injection practices.
} 
platforms in the North Sea (e.g., Minton et al. 1992; Brakel et al. 1997; Van Gils et al. 1995), the THUMS production islands in Long Beach Harbor, California (Hainey et al. 1997, 1999; Keck 1999, 2000), and offshore regions elsewhere in the world (e.g., Reddoch et al. 1995, 1996; Holt et al. 1995). Although many slurry injection jobs have been conducted in the Gulf of Mexico (Apollo Service 2002), they represent the solid wastes from just a small percentage of all the wells drilled there. This reflects the fact that some types of drilling waste discharges are permitted in the Gulf of Mexico whereas they are not always permitted in other areas. Also, the availability of cost-effective onshore disposal facilities in the Gulf of Mexico affects operator choices.

\section{Subfracture Injection}

In certain geological situations, formations may be able to accept waste slurries at an injection pressure below the formation fracture pressure. ${ }^{4}$ This practice is referred to in this report as subfracture injection. Wastes are ground, slurried, and injected as in slurry injection, but the injection pressures are considerably lower.

A commercial disposal company has received authority from the Railroad Commission of Texas (the state's oil and gas regulatory agency) to inject tens of millions of barrels of offshore waste into naturally fractured cap rock on the flanks of a salt dome in eastern Texas. The injection pressures are low, and on some occasions, the waste is drawn into the formation under a vacuum. According to Marinello et al. (2001), as of 2001, more than 22 million bbl of slurried waste had been injected using this mechanism, including more than $80 \%$ of the Gulf of Mexico offshore drilling waste brought back to shore and more than $90 \%$ of the naturally occurring radioactive material (NORM) from U.S. oil fields.

\section{Plugging and Abandonment}

Several U.S. states allow the injection of drilling pit wastes and reserve pit wastes back into the well of origin prior to abandonment (Puder et al. 2002). Some states, including Texas, Oklahoma, and Wyoming, allow injection pressures to surpass the fracture pressure; others use the upper pressure limit allowed for injection of produced water under the Class II Underground Injection Control (UIC) program. No across-the-board standard exists for the maximum allowable pressure; individual state limitations range from 0.5 to $0.9 \mathrm{psi} / \mathrm{ft}$ of depth. In some locations, drilling waste has been inserted into wells as spacer material during the plugging process. Most states consider this category separate from the fracture or subfracture injection processes described above. They view this process as a part of plugging and abandonment rather than injection.

\footnotetext{
${ }^{4}$ The formation fracture pressure (or fracture gradient) is the bottom-hole injection pressure required to open and propagate a hydraulic fracture; it is by definition equal to or slightly greater than the minimum compressive stress in the strata at that depth.
} 
The U.S. Minerals Management Service (MMS), which oversees waste injection activities located more than 3 miles from shore in the Gulf of Mexico, allows drilling waste to be injected into underground formations and to be encapsulated into the well bore of wells being plugged.

\section{Salt Cavern Disposal}

In the United States, disposal of drilling waste into salt caverns is currently permitted only in Texas, although Louisiana is in the process of developing cavern disposal regulations. Through August 2002, Texas had permitted 11 caverns at 7 locations. All of these caverns may receive exploration and production wastes, including drilling wastes, and three of them may also receive NORM. Several disposal caverns are also operated in Alberta and Saskatchewan, Canada, to receive slurried solid wastes, generally produced sand from heavy oil wells.

In the early 1990s, several Texas brine companies obtained permits to receive oil field waste, much of which was drilling waste, for disposal into caverns they had previously developed as part of their brine production operations. Uncertainty about this process led the DOE to fund four baseline studies of the technical feasibility, legality, cost, and risk of cavern disposal. The first study found that disposal of wastes in caverns was technically feasible and that there were no federal or state legal prohibitions against cavern disposal (Veil et al. 1996). A later study found that disposing of NORM - primarily contaminated pipe scale and tank sludges — in salt caverns was also feasible (Veil et al. 1998).

The use of caverns for oil field waste disposal depends on two primary factors - the presence of suitable salt formations and a sufficient volume of oil field wastes to make cavern disposal economical (dependent on transport distance). Salt caverns used for oil field waste disposal are created in salt formations by solution mining. Once solution mining is complete, waste slurries are pumped into the brine-filled cavern under low pressure - far below fracture pressure. The displaced clear brine is disposed by deep well injection.

Argonne conducted additional baseline studies on the cost and risk of cavern disposal. The cost study (Veil 1997) found that disposal in caverns could compete economically with other types of waste disposal methods used in the same geographic areas. Costs for oil field waste disposal in caverns in Texas were comparable to costs for disposal in other types of commercial disposal facilities. A fourth baseline study (Tomasko et al. 1997) assessed the risks posed by disposing of oil field wastes in salt caverns. That study found that use of disposal caverns posed very low human health risks. Additional information on salt caverns and their use for waste disposal can be found at the Salt Cavern Information Website, developed by Argonne for DOE (www.npto.doe.gov/saltcaverns ).

\section{Disposal in Coal Mines}

Old coal mines have been used in some instances for disposing of solid wastes, such as fly ash. Several states have coal bed methane $(\mathrm{CBM})$ or oil production in the geographical areas with coal deposits. Coal mines have never been used systematically for the disposal of oil field wastes except in Virginia, where the practice has occasionally been approved (Puder et al. 2002). 


\section{CHAPTER 3 - SLURRY INJECTION TECHNOLOGY}

The slurry injection process was briefly described in the previous chapter. In Chapter 3, the technology is described in greater detail. Some of the descriptive information is taken from the numerous slurry injection jobs summarized in the slurry injection database that is described more fully in a later chapter.

\section{Process Name}

The process referred to as slurry injection in this report has been given various other names by different authors. Some of the other names include:

- $\quad$ slurry fracture injection (e.g., Dusseault and Bilak 1998; Sipple-Srinivasan et al. 1998; Terralog, 2002a), [Note: this nicely descriptive term is copyrighted by a company that provides slurry injection services; therefore, Argonne elected to use a different term to avoid copyright issues.]

- $\quad$ fracture slurry injection (Kordzi 1998),

- drill cuttings injection (or reinjection) (e.g., Abou-Sayed and Guo 2002 ),

- $\quad$ cuttings reinjection (e.g., James and Rørvik 2002), and

- $\quad$ grind and inject (Schmidt et al. 1999).

To avoid confusion, these other descriptive names are not used in the remainder of this report.

\section{Overview of the Process}

Slurry injection involves straightforward and well-understood mechanical processes (e.g., grinding, mixing, pumping) and relies on the deployment of conventional oil field equipment. Before starting, the operator must have identified a suitable geological formation and obtained regulatory approval. This section presents an overview of the injection process in qualitative terms. The next section describes some of the types of slurry injection. This is followed by a description of preparation of the slurry, then by a lengthy section describing the phases of the injection process.

The first step involves making the solid waste material into a slurry having properties conducive to injection. The waste material is collected and screened to remove large particles that might cause plugging of pumps or well perforations. Liquid is added to the solids, and the slurry (or the oversize material) may be ground or otherwise processed to reduce particle size. Various additives may be blended into the slurry before injection to improve the viscosity or other physical properties.

Next, the formation is prepared to receive the slurry. Clear water is first injected to pressurize the system and initiate hydraulic fracturing of the formation. When the injection system is fully pressurized, the slurry is introduced into the well. Slurry injection continues until the entire batch of slurried material has been injected. To protect the well, additional water is then injected 
to flush solids from the well bore, and the well is then shut in under pressure. If the formation is somewhat permeable, the pressure will decline as the injected fluids bleed off over the next few hours, leaving the solids in place in the formation. Under the commonly used intermittent injection strategy, the process is then repeated the following day.

\section{Types of Slurry Injection}

There are several different features by which slurry injection operations can be distinguished.

Injection Mechanism - There are three primary mechanisms by which the slurry can enter the formation. The first two mechanisms use injection though the annular space between two casing strings of a well (Figure 1). The well used for annular injection can be one that is being actively drilled (Saasen et al. 2001), and this has been used for single onshore wells, exploratory wells, or for the first well in a development program. By far the most common alternative is to practice annular injection into a well that has previously been drilled and completed. The well may be producing fluids or may be an active water injection well in a water flood. Many of the slurry injection jobs listed in the slurry injection database follow this approach. The third mechanism is injection into a dedicated slurry injection well completed or recompleted specifically for that purpose (Figure 2). Most often, this type of well is completed with a packer, and injection occurs through a tubing string. This mode is generally used when large volumes of waste are to be injected through a single well. In some instances, an older inactive production well may be converted to a slurry injection well. Kunze and Skorve (2000) describe a different approach used on Jotun B, a Norwegian North Sea platform, in which the first well was drilled part way to its target depth but was stopped before oil-based muds were used. The well was temporarily completed as a dedicated injection well to receive the drilling wastes from subsequent wells. The operator intends to complete that well as a production well at the end of its drilling campaign on the platform.

Continuous or Intermittent Injection - On some jobs, the injection process is continuous. The Grind and Inject project on the North Slope was designed to inject continuously, 24 hours per day during the winter months (Schmidt et al. 1999). On some offshore platforms, where drilling occurs continuously and storage space is inadequate to operate in a daily batch manner, injection must occur continuously as new wells are drilled. In these cases, injection pressures are carefully monitored so operators can be aware of changes in formation injectivity and identify incipient problems. Most other injection jobs are designed to inject intermittently (i.e., inject for several hours each day, then allow the injected fluids to dissipate into the formation). The intermittent approach can help to repeatedly induce new fractures each day rather than lengthening the original fracture. This approach minimizes the likelihood that fractures will extend outside of the targeted formation and may allow for fracturestorage of a larger volume of solid material. A more detailed description of the intermittent injection process is given in a later section of this chapter.

Longevity of Injection Program - Many injection jobs are designed to receive wastes from just one well. On multiwell platforms or onshore well pads, the first well drilled may receive wastes from the second well. Each successive well has its drilling wastes injected into 
the previously drilled well (e.g., Minton et al. 1992; Willson et al. 1993). In this mode, no single injection well is utilized for more than a few weeks or months. Puder et al. (2002) note that most states that allow annular injection of drilling wastes also place a 30- to 120-day time limit on the approval to inject into any given well and may restrict the injected wastes to drilling wastes generated at the same well. Some states (particularly Alaska) may place restrictions on the volume of waste that can be injected into specific wells. Other injection programs, particularly those in which a dedicated injection well has been constructed, may operate for months to years. For example, slurried drilling wastes have been injected into several different formations from the dedicated injection well on the THUMS production island in Long Beach, California, for more than 5 years (Hainey et al. 1997, 1999; Keck 1999, 2000).

\section{Solids Handling and Preparation of the Slurry}

In most drilling operations, the mud and cuttings are transported from the drilling bit through the annular space outside the drill pipe, through an atmospheric pressure flow line near the rig floor, to a shale shaker (vibrating screen used to separate muds and cuttings). The mud is returned to the drilling system, and the cuttings, coated with mud, are sent to different destinations, depending on the location and type of waste management system. For onshore wells, cuttings are typically sent to a reserve pit or are stored in tanks if pits are not used. For offshore wells, cuttings may be stored for onshore disposal (skip and ship approach), treated further and discharged, or moved to an injection system.

The aboveground facilities for onshore slurry injection are not complex. Offshore facilities will also require equipment to perform the same activities, but because of space and weight limitations, the equipment will be engineered to fit the available space. Typical handling activities include:

- initial separation of muds and cuttings (shale shakers, cuttings dryers, centrifuges),

- transportation of cuttings to a slurrying system (vacuum systems, conveyors, augers),

- mixing with liquid (usually seawater or produced water; could include deck wash water),

- grinding or reduction of particle size (several options described below),

- $\quad$ storage (tanks), and

- pumping downhole (usually using triplex pumps).

The slurry is formed by mixing the drilling waste with liquid. Depending on the location of the well, seawater, fresh water, used drilling muds, or produced water, as approved by the regulatory agency is used. Other oil field wastes, such as tank bottoms, workover and completion fluids, and stormwater, may be added to the slurry as well. The slurry is processed to reduce or control the particle size. The desired particle size varies depending on the geology, porosity, and permeability of the injection formation, but often is stipulated to be less than 300 microns (micrometers, $\mu \mathrm{m}$ ). This roughly corresponds to particles that can pass through a 50-mesh screen. Several different types of solids processing equipment are described in the literature. The most common type is a centrifugal pump that has hardened edges on the impeller (Malachosky et al. 1991 was one of the earliest papers to describe this system). As the fluids are 
circulated within a tank by the pump, larger particles are ground into smaller ones. Other solids processing approaches that have been used include:

- ball mills (Syed and Cutler 2001; Schmidt et al. 1999; Susich 2002),

- vertical rolling mill (Minton and Secoy 1992),

- crushing mill (Sirevag and Båle 1993,

- grinding mills (Wood et al. 1995; Schuh et al. 1993), and

- ultrasonic processing (Glansbeek et al. 1998; Brockway et al. 2002).

The percentage of solids in the slurry is controlled to achieve the desired density, and viscosifiers can be added to keep the slurry in suspension. Table 2 summarizes data from the slurry injection database that relates to slurry composition. The table also shows the slurry parameters that are recommended as best operating practices in several other reports.

Table 2 - Comparison of Actual vs. Recommended Slurry Parameters

\begin{tabular}{|c|c|c|c|c|c|}
\hline & Actual Performance & \multicolumn{4}{|c|}{ Recommended Values } \\
\hline Parameter & $\begin{array}{c}\text { Data Summarized } \\
\text { from Slurry Injection } \\
\text { Database } \\
\text { (shown as overall } \\
\text { range and, in } \\
\text { parentheses, range } \\
\text { encompassing most } \\
\text { values) }\end{array}$ & $\begin{array}{l}\text { E\&P Forum } \\
\text { (1993) }\end{array}$ & $\begin{array}{l}\text { Buller } \\
(1996)\end{array}$ & $\begin{array}{c}\text { Abou- } \\
\text { Sayed } \\
\text { and Guo } \\
(2002)\end{array}$ & $\begin{array}{c}\text { Crawford and } \\
\text { Lescarboura } \\
\text { (1993) }\end{array}$ \\
\hline Percent solids & $5-70(10-26)$ & $20-40$ & $20-30$ & - & $12-15$ \\
\hline $\begin{array}{l}\text { Specific gravity } \\
\left(\mathrm{g} / \mathrm{cm}^{3}\right)\end{array}$ & $1.03-1.8(1.15-1.5)$ & $1.2-1.6$ & - & - & - \\
\hline Density (lb/gal) & $8.3-13.3(8.6-11.5)$ & $10-13.3$ & $9.5-12$ & - & - \\
\hline $\begin{array}{l}\text { Viscosity - } \\
\text { Marsh Funnel } \\
\text { (sec/quart) }\end{array}$ & $42-110(50-90)$ & $50-100$ & $60-90$ & $>60$ & $50-70$ \\
\hline $\begin{array}{l}\text { Particle size } \\
\text { distribution }\left(\mathrm{D}_{90}\right. \\
\text { in } \mu \mathrm{m})\end{array}$ & - & 300 & 300 & 300 & 300 \\
\hline
\end{tabular}

The actual reported values from the database match up well with the various recommended values. For the most part, the four sources of recommended practices are consistent with one another. One exception is Crawford and Lescarboura (1993), who recommend a lower solids content than the other sources. 


\section{Typical Slurry Injection Cycle}

Figure 3 shows a pressure vs. time plot for 2 days of a typical injection cycle. This is a hypothetical example of a relatively large-scale, land-based, dedicated-well slurry injection operation. A detailed explanation of this diagram helps to clarify the procedure. The following paragraphs, based on co-author Dusseault's experience with slurry injection of oily sands in Canada, explain the stages of the process and refer to stage numbers, which correspond to the numbers on Figure 3. The procedures followed for injection of cuttings at offshore platforms are similar to those used for the onshore operations described here, with some modifications related to rates, slug size, slug composition and density variations, and downhole pressure monitoring. Short-term annular injection operations often are less complex than those described below. Therefore, not all process stages or equipment will necessarily be the same for annular injection operations. The overall process is similar, however, and the following description is instructive for annular injection operations too.

Stage 1: Set-up - The operating crew arrives on site for the daily injection cycle. The injection unit is checked, and all the engines are started and allowed to warm up to reach operating temperature (particularly important in cold weather). Once warm, all engines are checked for oil pressures and temperatures, and water is circulated to ensure that all lines are open. A visual check of all flow lines, including the injection wellhead, is undertaken. Any safety tests mandated by regulatory agencies or recommended because of following proper practices are carried out in an appropriate manner. Such tests may be, for example, of electrical breaker systems, hydraulic systems, or pressure relief valves on the injection pump and highpressure lines.

The fluid levels in the storage tanks are checked to ensure that sufficient water is available for the daily slurry operations. If an external water source is used, such as a flow line from an adjacent tank farm or water pit, sufficient flow rates are verified by partially filling the slurryaveraging tank.

If a stockpile or a hopper storage system for solid waste is used, the supply of cuttings, sand, or other granular wastes is visually verified to ensure that a full day's operation can proceed; usually a minimum of 3,000 - 5,000 bbl is disposed of in a 6- to 10-hour injection period, and as much as 10,000 bbl can be disposed of in a 12- to 14-hour injection period. If solid waste is to be hauled directly to the site with trucks or sent by slurry pipeline from a local facility, these sources are verified to ensure that the solid wastes will be provided as needed.

The data acquisition system is checked to ensure that all parameters are being recorded, and the static bottom-hole pressure is recorded before injection begins (assuming that the well has remained shut-in since the end of the last injection episode). If the bottom-hole pressure shows that there has been very little pressure decay in the injection well bore region during the inactive period since the previous day, the project engineer is contacted before injection begins. 
Stage 2: Injection Initiation - If the slurry injection operations are re-initiated after a period of inactivity in the injection well, such as a shut down period of more than a few days, a series of injectivity tests or tracer tests may be carried out. These may include a step-rate injection test for assessment of the fracture pressure and injectivity and tracer tests to assess if there is any leakage along the casing-rock interface. If it is deemed necessary, or if it is required under the regulatory environment for the facility, a cement-bond log can be lowered down the well on a wireline system to detect the development of microannular space (small separation of the cement from the casing) outside the casing that could impair the flow integrity of the injection well. If there is concern about the near-well bore permeability, a well test involving pressure buildup and decay, or pressure decline then recovery, can be conducted. If special casing inspections are needed (e.g., multi-arm caliper to detect distortion, casing logging to detect corrosion), these are carried out at this time because the formation pressures around the well will be at their lowest point in the slurry injection project. In general, step-rate injection tests and pressure buildup tests should be carried out by the injection facility operator for purposes of general good practice, because these measurements allow changes of fracture pressures and general reservoir response to be tracked over time. More complicated and expensive tests, such as a cement bond log, may be needed only at very long intervals, or if there is other evidence of seal impairment. Decisions on the execution of complex tests should be made only after assessment by a qualified engineer.

If there are pressure relief valves or other safety devices on the injection pump, the hydraulic power system, or other parts of the injection system, these devices should be tested after any shutdown period exceeding a few days. For all safety devices and systems mandated by environmental, health, and safety rules and guidelines, the testing requirements stipulated by the governing regulatory body must be followed.

When the slurry-averaging tank is nearly full of solids-free water, injection is initiated by starting the centrifugal charge pump and the triplex pumps and opening the valve to the wellhead, injecting clear water either from the averaging tank, or from an ancillary tank. As flow is initiated from the averaging tank, the inflow rate of water to the averaging tank water jets is increased to the same as the injection rate to keep the level constant in the averaging tank, approximately two-thirds full.

During this water injection start-up phase, the bottomhole pressure is carefully monitored as it increases above the initial static pressure. There is always a small risk that the well bore has become plugged during the preceding shutdown period. The criterion used to decide whether the well is plugged is the rate of pressure increase as the pump is started: a sudden increase to a value substantially higher than the previous day's injection pressure is an indication that something has changed. The triplex pump is also equipped with a pressure relief valve to prevent damage to the system if a sudden pressure spike occurs, and if this valve opens, it may be assumed that the well is blocked. If the well is plugged with solids, a workover may be necessary. A proper pressure response in a slurry injection well that has been in use through at least several previous cycles is a relatively rapid increase to a bottomhole pressure that is about 15 to $25 \%$ higher than the overburden stress $\left(\sigma_{v}\right.$ - the vertical stress imposed by the mass of the rock overlying that depth), followed by a drop in pressure to a value perhaps 5 to $15 \%$ greater 
than $\sigma_{\mathrm{v}}$. The pressure peak corresponds approximately to what is called the "breakdown pressure" in conventional hydraulic fracturing operations.

Stage 3: Steady Fracture Propagation, No Solids - The pumping rate on the triplex pumps is brought to the value that will be used during the slurry injection period. Depending on the well completion and the design of the slurry injection pumping unit, this value typically ranges from $8-16 \mathrm{bbl} / \mathrm{min}$. Once the system is flowing, the density meter on the exit flow line from the slurry averaging tank is checked to make sure it is recording at the density of water (1.0 $\mathrm{g} / \mathrm{cm}^{3}$ for fresh water, or higher if a briny produced water stream is being used). Flow is continued until the water from the surface has totally flushed the tubing and perforation system. Typically this will involve about $60-100 \mathrm{bbl}$ of water and will take at least 8-10 minutes of pumping time. This not only allows time to ensure that all pumping parameters are correct, it also helps clear the near-well bore environment of solids material and opens up preliminary flow channels (induced fractures) around the well bore. These channels are now full of flowing liquid, so the entire system from the pumps to the formation has momentum.

Stage 4: Initiation of Solids Injection - The solids content of the water being injected is increased over a period of approximately 15 minutes by starting the solids feed system. The density of the triplex pump effluent is monitored continuously as the solids content in the averaging tank gradually approaches a steady-state condition. Water input is adjusted to keep the level in the averaging tank approximately constant. The target for injection density of the slurry depends on the nature of the wastes, the density of the aqueous phase, and the response history of the injection well and the reservoir.

During this phase, the bottomhole pressure will gradually climb to a value that is on the order of $1.15-1.30 \sigma_{\mathrm{v}}$. The pressure vs. time plot shows short-term fluctuations of $2-4 \%$ of the average pressure; this is a response to small fluctuations in the slurry density and to changes in how the formation takes the slurry. If the injection bottomhole pressure is deemed to be too high, the solids content may be reduced or the injection rate altered.

Solid materials should be kept in full turbulent flow throughout the system to avoid the generation of dense slugs. The injection rates should be kept high and the slurry averaging tank kept agitated, particularly if coarse-grained sand is being injected. If clay slurries, such as spent mud and ground shale, are being disposed of, injection can take place at lower rates if it is deemed appropriate by the project engineer.

Phase 5: Steady-State Slurry Injection - The injection rate is usually maintained constant for the entire solids disposal injection period, simply by running the positive displacement pumping system (the triplex pumps) at the same number of strokes per minute. The injection density is kept in the desired range by adjusting the feed rate from the waste loading hopper. Speeding up the feed rate results in a higher density, and slowing down the feed rate reduces the solids content. 
If sand is being injected along with clear water, the pressure vs. time plot will continue to show short-term fluctuations of $2-4 \%$ of the average pressure. The average injection pressure may climb and drop by as much as $10 \%$ over a period of time. However, in some cases it is common for the pressure vs. time plot to show a gradual increase in pressure to close to $1.30-1.35 \sigma_{\mathrm{v}}$ over a period of many hours, then drop off over a relatively short time of perhaps 10 minutes or less. These intermediate-term cycles are characteristic of slurry injection, and are interpreted as fracture orientation changes; once local stresses rise above some value, it becomes energetically more favorable for the fracture to reinitiate at the well bore in a different orientation. In other words, in response to the placement of large amounts of solids in induced fractures, the size and orientation of the fracture zone in the general injection region can change with time and solids input rate.

Phases 6 and 7: Cessation of Slurry Injection - Slurry injection is continued for the desired time, and then the system must be shut down properly to guarantee that the surface equipment and the well bore are free of solids in suspension. The first step is to stop adding solids by turning off the solids feed system (Phase 6). Depending on the technology used, it may take up to 5 minutes for solid matter to stop entering the averaging tank, and another 15-20 minutes until the solids content of the slurry being fed to the pump is reduced to negligible quantities. The averaging tank level can be dropped so that the process is accelerated. Flow line samples can be taken, if desired, to physically examine the solids content of the slurry to verify that it is sensibly solids-free. It is important to have only a minimal amount of solids in the bottom of the averaging tank so that the mixing system can be started again for the next day's injection cycle.

Once solids-free liquid is being injected, pumping is continued to flush the well bore thoroughly (Phase 7); from two to four well bore volumes are injected, on the order of $60 \mathrm{bbl}$ for a typical 3000-foot-deep injection operation using 3-inch tubing. This flushing can be carried out with completely solids-free water from an ancillary flow line that circumvents the averaging tank to make sure that there will be no solids in the well bore to settle out and block the perforations at the bottom of the hole.

Once the cleanout and shutdown procedure has been completed, the valve to the wellhead is closed, and the well is shut-in under pressure. It is important that the well bore not be depressurized at any time, so that sand or other solids material does not flow back into the well bore.

If a site is practicing continuous injection through a series of wells, pumping of slurry can be switched to another injection well at the end of Stage 7 simply by changing the pump outlet manifold valves to direct the clear water to the next injection well. Then, the process starting at Stage 1 is repeated in the same manner.

Stages 8, 9 and 10: Monitoring Reservoir Leak-off - Once the slurry injection well is shut in, the bottomhole pressure and wellhead pressure are monitored continuously. The data acquisition system is usually placed on a fast sampling rate (e.g., once every 5 seconds or faster) just before shut-in because the initial pressure drop-off is quite rapid as the fracture closes. The 
bottomhole pressure will typically drop to a value below $\sigma_{\mathrm{v}}$ quite rapidly (Stage 8 , a few minutes). After the first 20-30 minutes, the data acquisition rate slows down (e.g., once every minute or two) to track the continued slow pressure dissipation (Stages 9 and 10). Typically, the shape of the pressure vs. time plot reflects linear flow away from a fracture during Stage 9, then it transmutes into radial flow as the pressurized region around the well bore gradually dissipates its pressure to the far-field during Stage 10.

The pressure drop rate after injection is controlled by the permeability structure of the large injection region around the well bore. If the injection process involves pure sand and water, with no clay or hydrocarbons, the bottomhole pressure is observed to continue to decay rapidly, usually in a few hours, until it is within $10 \%$ of the far-field pressure $\left(\mathrm{p}_{\mathrm{o}}\right)$. The value of $\mathrm{p}_{\mathrm{o}}$ is assumed to be constant throughout the project because of the large size of the target reservoir. If the injection process included fine-grained mineral matter, such as drilling waste or tank bottom sludge, the permeability of the reservoir around the injection well will be reduced, and the pressure will take longer to drop. If excessive amounts of viscosity-controlling materials are introduced into the slurry, the permeability may become impaired, and the near-well bore region may remain pressurized at values substantially larger than the far-field pressures for days. This is not considered desirable, and operational procedures are implemented in such cases to eliminate or reduce the condition.

During the shut-in period, the pressure data are analyzed qualitatively before the next injection period if there is any concern over the reservoir or well bore region behavior. If the pressure drop is judged to be "insufficient," a function of the well history and the nature of the injected materials, this will affect the nature of the injection process in the next injection period. Also, if any offset wells are pressure instrumented, these data are examined for the entire period of injection and leak-off to see if there is any significant pressure response in the far field. If, for example, there is evidence of formation blocking that inhibits leak-off, pure sand and water may be injected for a long period the next day to generate more permeable paths to help accommodate leak-off more rapidly.

\section{Long-Term Injection Processes}

In typical projects, the injection cycle described above is continued on a daily basis until the entire waste volume is injected, or for 12-20 days if the volume of waste to be disposed of is larger than can be accommodated in less than three weeks. If injection is to continue, the well is placed in a shutdown mode for at least several days to obtain long-term pressure decline data from the reservoir, so that the leak-off rate to the far-field can be determined. This is shown in Figure 4 as a pressure response over time with a 3-day shutdown period. During this shutdown period, the injection well remains closed to allow long-term reservoir response measurement. All data from the previous two or three weeks of injection are plotted and analyzed to make sure that the reservoir response is satisfactory, in order to delineate the best approach for project continuation. As shown in Figure 4, slurry composition can be changed on a day-to-day basis or even a minute-to-minute basis to maintain optimum injection and pressure decay response. 


\section{Slurry Injection of Wastes Other Than Drilling Wastes}

This report focuses on slurry injection of drilling waste, which has been the most commonly type of waste injected. However, in many injection jobs, other types of oil field wastes (e.g., produced sands, tank bottoms, oily wastewater, pit contents, NORM) are commingled with drilling wastes during injection. For example, Lowe (1993) describes the process followed to allow injection of NORM along with other oil field wastes on the North Slope of Alaska, and Hardy and Khatib (1996) describe injection of NORM material in the Gulf of Mexico.

Hagan et al. (2002) describe an onshore facility (Wytch Farm, in the United Kingdom [UK]) and an offshore facility (Valhall platform - Norwegian North Sea) that have interspersed drilling waste injections into wells normally used for produced water injection. There had been concern that injection of solids would plug the water injector, but this has not occurred.

Another example of injection of oil field waste is disposal of oily sands and tank bottoms from western Canadian heavy oil production. Dusseault et al. (1994), Sipple-Srinivasan et al. (1997), Dusseault and Bilak (1998), and Terralog (2001) describe several Canadian injection jobs.

Syed and Cutler (2001) describe a series of injection wells on the North Slope of Alaska that are permitted as Class I UIC wells rather than as Class II wells (typical oil and gas injection wells). Because of that classification, the wells are authorized to dispose of many different types of wastes that are generated in that remote environment. For example, the wells can inject seawater, brine, sewage, crude oil, spent acid, diesel, contaminated snow, methanol, line pigging wastes, and boiler water, among others. Regg and Maunder (2003) report that these Class I wells referred to do not all accept slurry. The three wells at Prudhoe Bay and the one at Alpine only accept "clean" fluids. Solids are specifically screened out. The Badami well was permitted to accept slurry; however, volumes have been minimal so far. The Northstar well is accepting the real-time drilling waste being generated, as well as other waste streams. The Northstar well, unlike most other Class I wells permitted by the EPA, is allowed to exceed the fracture pressure for waste injection only because no underground source of drinking water (USDW) is found near the well.

Omrcen et al. (2001) and Brkic and Omrcen (2002) describe injection activities in Croatia. The first paper discusses disposal of sulfur slurry that is produced during processing of gas and condensates. Three abandoned dry-hole production wells were used to inject sulfur slurry in a $5 \%$ bentonite slurry, along with drilling wastes, workover fluids, and refinery wastes. Omrcen et al. (2001) report that some of the injection was conducted below fracture pressure, while other injection was conducted above fracture pressure. In a more recent paper, Brkic and Omrcen (2002) recommend a rationale for additional injection of activated carbon particles impregnated with mercury sulfide and ash from incineration of hazardous and nonhazardous wastes.

Yod-In-Lom and Doyle (2002) describe a project to dispose of several thousand barrels of mercury-contaminated sludge from a floating storage unit in the Gulf of Thailand. The sludge had accumulated in drums for several years; in 2001, it was slurrified and injected at the Baanpot Alpha 08 offshore platform. 
Sipple-Srinivasan et al. (1998) describe a project in which more than 14,000 bbl of soils contaminated by crude oil spills, along with some drilling muds, was injected over a three-week period at the West Coyote field in La Habra, California. Injection was into a depleted oil sand formation at a depth of approximately 4,100 feet.

One other example of solid waste slurry injection outside of the oil and gas industry is currently under consideration by the EPA in California. The City of Los Angeles proposes to inject a slurry of biosolids (sewage sludge) into a depleted oil and gas formation located just outside of the city (Bruno 2000). The project claims several advantages, in addition to waste disposal. Because the biosolids are biodegradable, they would release carbon dioxide if degraded in an aerobic environment above ground. This would increase the production of greenhouse gases. If the same materials are injected underground into an anoxic zone, biodegradation would yield methane. This offers a dual advantage: less greenhouse gas is emitted to the environment and methane can be recovered and reused as a fuel source.

\section{Feasibility of Slurry Injection Technology}

Slurry injection has been used successfully in many locations around the world to dispose of drilling wastes and other solid materials. Although some injection jobs have not worked well (detailed discussion follows in Chapter 6), the reasons for these problems are understood and can be overcome by proper siting, design, and operation. When slurry injection is conducted at locations with suitable geological conditions and the injection process is properly monitored, slurry injection can be a very safe disposal method. Because wastes are injected deep into the earth below drinking water zones, properly managed slurry injection operations should pose lower environmental and health risks than more conventional surface disposal methods. 


\section{CHAPTER 4 - GEOLOGY AND FRACTURING}

Slurry injection involves injecting material into underground formations at pressures high enough to fracture the rock. To understand how and why slurry injection works and what injection operators must consider, it is useful to examine relevant aspects of the geology of the injection zone and the layers above and near that zone. Likewise, a review of fracture creation and propagation theory is valuable for understanding where the slurry goes when injected. This chapter discusses both of these topics. The literature is extensive in both areas, and frequently the information is highly quantitative. The discussion of these topics in this chapter is intended to evaluate the technology in a qualitative manner that complements the report without delving into the detailed quantitative and computational aspects of those sciences.

One of the earlier papers written on slurry injection (Andersen et al. 1993) poses five questions concerning downhole considerations that set the stage for this chapter's discussion:

1. Into what formation can the slurry be injected?

2. How will the fracture be contained?

3 . In what direction will the fracture propagate?

4. How big will the fracture grow?

5. What impact will injection have on nearby wells?

\section{Desirable Characteristics for Injection Formations}

There are two schools of thought on the most appropriate type of injection formation, primarily based on whether the operator uses annular injection or injection through a dedicated injection well completed with tubing and packer.

Annular Injection - In many cases, annular injection occurs in wells that are currently being drilled, are being used for some other purpose, or will be used for some other purpose in the future. The wells are designed for multiple purposes and are not necessarily designed to optimize injection. Annular injection leads to fracturing beneath the casing shoe of the outer of two adjacent casing strings. Generally, casing shoes are set in shale layers. Thus, annular injection is most often conducted in shales, which have low permeability. However, the vertical section of formation between the shoe of the outer casing and the top of cement behind the inner casing may include a lengthy sequence of sands or other high permeability layers that is located not far below the casing shoe, and that can be used for injection (Ginn 2003).

Injection into shale tends not to "screen out" or clog the fracture tips with solids because the liquid portion of the slurry is unable to bleed off through the low permeability formation. A disadvantage of injection into shales is that the resulting fractures are likely to grow larger and may extend beyond the upper boundary of the shale layer, possibly leading to leakage into inappropriate areas. There is also a chance that remnant high pressures because of the slow bleed-off could impair continuing drilling operations. One approach to mitigating these problem is to select shale layers for shoe placement that are overlain by permeable sand layers. Such 
layers provide a zone to bleed off excess fluids when fractures extend to the top of the shale, and thereby help prevent further vertical extension of the fracture. In the absence of such a sequence of sand and shales, annular injection may not be the best candidate technology for waste disposal and alternatives should be evaluated.

Dedicated Injection Well - When the operator is able to design a dedicated injection well, most often it will be completed to inject into a sand formation with high permeability. Fracturing into sand layers can lead to the rapid leak-off of the slurry liquid, thereby causing solids to screen out at the tips of fractures (see Figure 5). For this reason, Abou-Sayed and Guo (2001) suggest that injection into highly permeable formations is not the best choice when the rate of waste generation is low. Quickly plugged fractures (rapid screenout) limits the length of the fractures but may allow for a larger volume of solids to be disposed of in a formation through creation of multiple fractures. Thus, highly permeable formations make a good choice when large volumes of waste must be disposed.

The sand layer should be overlain by a layer with low permeability, such as shale or mudstone. This containment zone serves to limit further vertical propagation of the liquid phase of the injected slurry.

Other Characteristics - Regardless of which type of rock is selected for the injection formation, preferred sites will be overlain by formations having the opposite permeability characteristics (high vs. low). When available, alternating sequences of sand and shales are good candidates, with injection taking place into one of the lower layers, so that the upper layers serve both as containment barriers (low permeability) and rapid leak-off zones (high permeability) to arrest upward fracture growth.

An optimal target formation for large-volume injection jobs will be thick, relatively level, and extend for a large distance laterally. Terralog (2002a) recommends that formations should be at least 65 feet thick and laterally continuous for more than 10 square miles (about 2 miles in all directions from the injection point). A larger formation, both vertically and laterally, will be able to store a greater quantity of waste material. Smaller volume, short-term annular injection jobs do not need as large a target formation.

Slurry injection jobs should be designed to ensure that fracturing does not allow fluids to migrate to drinking water aquifers, the ground surface, or the sea floor (for offshore locations).

Therefore, the target formations should not be located too close to the surface or to sensitive aquifers and should be vertically separated from them by appropriate barriers. Likewise, fractures should not interfere with formations that are currently producing oil and gas or that may be used for production in the future. Some geological features that could allow undesirable injection consequences include faults, local seismic activity, overlying rocks that are intensely natural fractures, and steeply dipping formations. Injection into such areas should be avoided or studied with care and conservatism before proceeding. 


\section{Introduction to Fracturing}

In 1947, the oil and gas industry began fracturing producing formations to stimulate additional production (Gidley et al. 1989). Since then, many thousands of wells have been hydraulically fractured. The process of fracturing involves pumping a fluid into a formation at a rate and pressure that exceeds the formation's ability to assimilate the fluid into the rock matrix, therefore the injection pressure must rise. At some point, the rock cracks or fractures in response to the elevated pressures. Depending on the pressure, the volume of injected fluid, the slurry characteristics, and the length of time that high pressure is applied, the fracture will grow (propagate outward) and will follow an orientation that depends mainly on the stresses in the rock layers. Local lithostratigraphy and rock properties such as permeability and stiffness may also affect the shape and orientation of the induced fracture..

During the stimulation period, solid particles of selected size and shape (proppants) are introduced into the newly created fracture. When pressure is released, the proppant remains behind to keep the fractures open, creating paths of high permeability through which oil and gas can flow more easily to the well. Many papers and texts have been written on hydraulic fracturing. One recent document that offers a good introductory discussion on the subject is a white paper prepared for DOE (Holditch 2001) and submitted to EPA to use as part of EPA's study on hydraulic fracturing of coal bed methane reservoirs (EPA 2002).

The lessons learned from fracturing formations to stimulate production can be applied for slurry injection, but there are important differences, as pointed out by Keck (2002). Stimulation often uses fluids with high viscosity and high solids content, whereas slurried waste injection always uses lower viscosity fluids with variable solids content. Stimulation typically involves a shortterm injection (generally several hours) of a single batch containing solids, whereas slurry injection (particularly intermittent injection) involves a protracted program involving injection of many batches of solids over weeks or months into the same well.

\section{Fracture Growth and Shape}

A deep underground formation has compressive stresses acting against it in all directions. To distinguish among these, we call the two horizontal stresses $\sigma_{\mathrm{h}-\max }$ and $\sigma_{\mathrm{h} \text {-min }}$ and the vertical stress $\sigma_{\mathrm{v}}$ (Figure 6a). At depths of several thousand feet, where slurry injection occurs most frequently, the overburden weight of the rock $\left(\sigma_{\mathrm{v}}\right)$ is usually the strongest stress, with $\sigma_{\mathrm{h}-\max }$ being intermediate, and $\sigma_{\mathrm{h} \text {-min }}$ being the least stress. The mechanics of fracturing dictate that hydraulically induced fractures will almost always propagate in a direction perpendicular to the direction of least stress. The least stress direction is the $\sigma_{\mathrm{h} \text {-min }}$ direction, and therefore the fracture will propagate as a vertical fracture at about $90^{\circ}$ to the $\sigma_{\mathrm{h} \text {-min }}$ direction (Figure $6 \mathrm{~b}$ ). The resulting fracture assumes the shape of a single vertical plane. If injection is sustained so that pressure in excess of the fracturing pressure is continuously applied to the formation, the fracture will grow outward and upward (Figure 6b) until it intersects a zone of high permeability (which dissipates the pressure), or a zone of higher horizontal stress (the confining layer). If a fracture 
encounters a high permeability zone that can absorb all the injected fluid, growth will cease. If a vertical fracture encounters a stress barrier that stops vertical propagation, the fracture will continue to grow laterally beneath the confining layer.

In some regions of the earth, most commonly at shallow depths and onshore, the least stress is not horizontal but vertical. In these cases, the fracture growth is mainly horizontal, but usually with a shallow rise angle (Figure 6c). Because the least stress in these environments changes with depth, a deep vertical fracture may rise until the point where $\sigma_{\mathrm{v}}$ is no longer the greatest stress. Then, fracture growth in the vertical direction will cease, although the fracture may continue to propagate in the horizontal direction from the top of the vertical fracture section.

The previous paragraphs describe with minimum detail the traditional single-plane hydraulic fracture theory. This could be relevant to some continuous injection episodes; however, evidence is accumulating to suggest that when large-volume waste injection is conducted in an intermittent fashion and the formation is allowed to rest after each injection cycle, a more complicated fracture pattern is formed. In 1993, Moschovidis et al. (1993) proposed a new conceptual model for cuttings disposal known as the "disposal domain". The model predicts that after the first few injection episodes, $\sigma_{\mathrm{h} \text {-max }}$ and $\sigma_{\mathrm{h} \text {-min }}$ in the vicinity of the injection well bore become equal, and there is no longer a single preferred azimuth for the fracture plane (the azimuth is the angular direction from north for the orientation of a vertical planar fracture). Subsequent injections would be expected to create a series of vertical fractures that have slightly different azimuths within an angular range (the disposal domain). These fractures may connect with one another. As long as the injection episodes inject similar volumes of slurry, each fracture will have a similar size. Figure 7 depicts the disposal domain concept. Tiltmeter data from shallow fracturing (-2000 feet) in Alberta (Dusseault and Rothenburg 2002) suggest that in projects involving large waste volume injection into poorly consolidated sandstones, there are also large components of horizontal fracture plane orientations, as well as vertical. Therefore the domain disposal concept can be extended to include sets of fractures at different inclinations as well as different azimuths.

The disposal domain concept suggests that a large volume of waste can be accommodated in a zone near to the injection well bore. Instead of disposal being limited to a single planar fracture, waste materials can be disposed of in numerous fractures at different orientations, forming a complicated waste pod around the well. The advantage of multiple smaller fractures over a single large fracture is that no one fracture is likely to grow so high vertically that it intersects inappropriate aquifers or surface features, or so far laterally that it interferes with other well bores located some distance away. Thus, the solid wastes are kept in a region relatively close to the injection well bore.

A consortium of researchers conducted a carefully designed and heavily monitored series of injection trials in Mounds, Oklahoma, in 1998 (Moschovidis et al. 1999, 2000). The results confirmed that intermittent injections create multiple fractures, thereby supporting the disposal domain concept. The Mounds trial contributed extensive information about slurry injection and some monitoring devices that provide useful information. The results and conclusions of the Mounds experiment are discussed in greater detail in the next chapter. 


\section{Prediction of Fracture Geometry}

Fracturing science relies heavily on modeling to predict the size and shape of fractures. This report does not offer any details on recommended models, how the models are designed, or how they operate. The mention of any model in this section is not an endorsement or recommendation of its merits. There are undoubtedly other models besides those mentioned in this section that have been used to estimate fracture dimensions. The authors have not intentionally excluded those models from discussion but have elected to mention a few models as examples of the types that have been used. Several references that discuss fracture modeling are described below.

Buller (1996) reports on the types of models that had been used by North Sea operators. They include pseudo-three-dimensional models (Gopher, FracPro, and STIMPLAN) and true threedimensional models (TerraFrac and Gyfrac) and some proprietary in-house models developed by the operators themselves.

Several additional recent references describe the current state of injection models. Terralog (2002a) provides a discussion of its efforts to use several types of fracture models to predict fractures from slurry injection projects. Terralog examined a two-dimensional model (the Perkins-Kern-Nordgren model) and a pseudo-three-dimensional model (FracProPT). Both models were modified to allow variation in shear modulus, leak-off coefficient, and closure stress. By varying these inputs, Terralog was able to more accurately mimic actual data. Terralog also developed a coupling process between a continuum flow model (FLAC) and a discrete particle model (PFC) that showed good potential for better simulation of fractures caused by slurry injection, but acknowledged that the new approach requires additional research and development.

Guo et al. (2000) used TerraFrac, a three-dimensional model, to determine the volume of slurry that could be safely injected into two wells at the Panuke Field, off the coast of Nova Scotia. The authors assumed the fracture would be a single, bi-winged fracture, which leads to a conservative estimate of the formation's ability to assimilate the injected slurry. Keck (2002) notes that this approach of conservatively assuming a single bi-polar fracture is little different from the approach used in the early years of slurry injection (e.g., Willson et al. 1993 also used TerraFrac to model fractures at the Gyda platform in the North Sea in the early 1990s), even though there is good evidence today that multiple fractures are developed during an extended injection campaign. Keck (2002) summarizes recent fracture modeling and concludes that although laboratory and field data agree that intermittent batch injection forms multiple fractures, the current models do not have the capability to model multiple fractures.

Hagan et al. (2002) acknowledge that none of the currently available fracturing models adequately addresses the case of drill cuttings injection commingled intermittently with produced water reinjection. 


\section{CHAPTER 5 - MONITORING DURING SLURRY INJECTION}

The size, shape, and orientation of fractures can be predicted through modeling, but it is important to have some indications of what is occurring in the formation to verify that fractures are not extending into inappropriate locations. Many types of monitoring devices can provide useful feedback to operators about what is happening underground. This chapter describes some of the methods that have been used during slurry injection jobs. Two important research projects on monitoring slurry injection - the 1993 Deep Well Treatment and Injection demonstration in Texas, and the 1998 Mounds experiment in Oklahoma - are also described here.

\section{Baseline Monitoring}

At a minimum, injection operators should continuously monitor injection pressure and injection rate. The slurry characteristics (density, composition) should also be frequently monitored.

Pressure - Pressure measurement gives a real-time indication of what is happening underground. Figure 3 shows a typical pressure vs. time plot. Any pressure trends that are notably different from those anticipated suggest that the formation is not behaving in the way predicted. Analysis of pressure behavior allows fracture model predictions to be validated.

Terralog (2002a) suggests that bottomhole pressure is the most important parameter to measure. Sensors should be able to take readings at least every 5 minutes during long periods when injection may not be taking place, and as often as every second during periods of rapid pressure changes. Bottomhole pressure allows for analysis of pressure fall-off or leak-off at the end of each injection cycle and gives good information about the size and shape of the fractures and waste disposal domain. Terralog (2002a) shows examples of how bottomhole pressure is used in step-rate tests to determine the fracture pressure of the formation and in injectivity tests to determine radial flow characteristics of the formation.

Pressure measurements made in other nearby wells (offset wells) gives evidence of changes in formation pressures caused by the injection job. Pressure sensors can be installed to monitor more than one formation, if desired. There is no technical limitation to the depth of installation of a bottom-hole pressure gauge because it is run into the hole along with the injection tubing. Reliable sensors for temperatures less that $225^{\circ} \mathrm{C}$ are widely available.

Rate and Volume - The rate of injection can be determined by counting the strokes per minute of the positive displacement pumping unit and multiplying by the displacement of the pump. Total volume can be determined by multiplying rate times duration.

Slurry Characteristics - Density can be measured manually at frequent intervals or can be continuously monitored with nuclear densimeters. Viscosity, particle size distribution, and solids content can be directly measured at intervals through flowline sampling. 


\section{Logging Methods Applicable to Slurry Injection}

After one or more injection episodes, an operator can attempt to learn the extent of the fractures by conducting several types of well bore logging.

Radioactive Tracer Logging - The injected solid material is tagged with a radioactive tracer having a short half-life. The tagged material can be located using a gamma-ray logging tool if the vertical fracture plane intersects the well bore axis. However, this gives just a rough approximation of the fracture location behind the injection well bore because the tagged material may only enter a portion of the fractured zone. In addition, this method is of little use if the injection well is inclined or if the fracture plane is largely horizontal.

Temperature Logging - Digital temperature gauges can be run downhole on a wire line. A $\log$ is run before injection is started to serve as a baseline and again after injection. The temperature of the slurry is close to ambient atmospheric temperatures, which are generally cooler than the formation temperatures. Where the temperature log indicates cooler zones downhole, there is a likelihood that slurry is nearby. This can also lead to an approximation of the fracture height adjacent to the well bore. Similarly to radioactive tracer logging, this method is ineffective if the injection well is inclined or if the fracture plane is horizontal. Furthermore, if there is a wide annular space between the casing and the rock that is not sealed with cement, liquids can propagate upward along the well axis even if there is no intersecting fracture.

Imaging Logs — Formations can be assessed by various imaging tools that are lowered on wire lines. One tool that was used in the Mounds Project (described below) is a Formation Micro Imaging log that measures changes in resistivity as the tool passes a fracture (Moschovidis et al. 2000). Another advantage of this tool is that it has directional survey capabilities to determine its location in three dimensions. However, it does require a non-cased borehole, and all that the tool can determine is the fracture geometry at the well bore wall: it can determine nothing about the propagation of the fracture beyond this small region.

\section{Other Monitoring Devices}

Several types of monitoring devices can be placed in separate monitoring wells or other locations surrounding the injection well. These devices offer a great deal of additional information about the way in which a fracture propagates.

Tiltmeters - Great precision in measurements, either at the surface or at depth, is provided by a tiltmeter, a geophysical inclinometer device that gives readouts with accuracy of approximately $5 \times 10^{-9}$ radians for tilt, and also gives the direction of the tilt (i.e., a tilt vector is provided by each tiltmeter site). If about 12 to 16 surface tiltmeter sites are available, the shape of the injected zone can be analyzed on a frequent basis (Dusseault et al. 1998). It is even possible to verify fracture orientation changes that are correlated to sudden changes in bottom hole pressure during continuous injection. Tiltmeters must be set up in a proper array to determine fracture geometry, and an array will cost approximately $\$ 4,800$ per tiltmeter, including remote data transmission capability (i.e., $\sim \$ 60,000$ to $\$ 100,000$ for a long-term array). In 
contrast to level survey arrays, readout from tiltmeters is electronic and "instantaneous", therefore as many data sets can be collected as is warranted by analysis needs. Each analysis of the changes of tilt between two times costs on the order of $\$ 500$.

Although precision tiltmeter measurements are the best method of determining the shape and general geometry of the fractures and the evolution of the region that is affected by the injection process, analysis results must be viewed as a statistical approximation. Because of the statistical nature of the method used to analyze the data, it is possible to separate the deformation shape into vertical and horizontal components. Also, the fracture length can be estimated, giving some information about the extent of the affected zone. Analysis of deformation data can give information about the distribution of volume changes and shear distortion (Dusseault and Rothenburg 2002), but cannot be used to give explicit information about the shear rupture of bedding planes; this requires microseismic monitoring. Surface tiltmeters have been used since the 1970s (Warpinski and Engler 2001). They offer good information on the azimuth and dip of fractures; however, they do not give precise information on the height and length of fractures. Also, the deeper the induced fracture, the smaller the magnitude of the surface signal, so there are practical limitations as to the depth of a process that can be monitored using only surface tiltmeters (this depth is on the order of 7,000 to 10,000 feet).

Downhole tiltmeters can accurately describe the heights and lengths of fractures (Branagan et al. 1996). Fixed-position downhole tiltmeters have been used since 1993 (Wright et al. 1999), and wireline-mounted arrays have been used since 1998 (Warpinski and Engler 2001). Wright et al. (1999) suggest that the resolution of fracture height and length is sensitive to the distance that the observation well is offset from the injection well (typically about 5-10\% of the distance to the offset well). Downhole tiltmeters are less accurate than surface tiltmeters for determining the azimuth of the fractures.

Microseismic Monitoring - A microseism is a small seismic shear event that occurs in a medium as the result of the changes in stresses. When the shear stress exceeds the shear strength, sudden failure takes place as a "stick-slip" movement, similar to an earthquake but of much lower magnitude. Changes in shear stress around the injection well at depth arise because of the volume changes that take place during slurry injection. Collection and localization of the events in a long-term operation can help determine general injection shape and the evolution of the process with time. If there is an accumulation of shearing displacements that are occurring on a specific bedding plane that could potentially lead to casing rupture, this can usually be detected well in advance of the actual casing failure. Microseismic monitoring cannot give information about the volume changes that occur in the medium.

A microseismic array consists of a group of four or more triaxial accelerometers or geophones installed in offset wells or as behind-the-casing sensors in injection wells. Surface installation is usually unproductive because of the small magnitude of the events and the refraction and attenuation that take place during seismic wave transit through heterogeneous layered media. Multiple receivers allow the location of the microseism to be determined, as well as the magnitude, the orientation of the slip plane, and the direction of movement. The accumulation of 
these data over time allows "clouds" of seismic data to be collected and analyzed, and the density and location of these "clouds" over time are related to fracture dimensions and growth.

Depending on the number of sensors and the availability of wells, a microseismic array, including the associated computer and the hardware, can be installed for about $\$ 80,000$ to $\$ 130,000$ (much more if wells have to be drilled). To install two triaxial sensors behind casing while cementing a 3,000-foot-deep slurry injection well will cost approximately $\$ 20,000$. Analysis and interpretation is an "ongoing" process that requires the dedicated activity of a trained person, and the incremental cost to a project of this may be on the order of $\$ 50,000$ per year.

Abou-Sayed et al. (2002) suggest that microseismic monitoring has the ability to detect multiple fractures and the extent of those fractures. Disadvantages of the technique include the relatively high cost, the accuracy, and the uncertainty of the angle of azimuth. In order to get excellent results from microseismic monitoring, it is necessary to employ a multi-well approach so that microseismic event locations and magnitudes can be determined using triangulation methods.

Hydraulic Impedance Testing - This technique has not been used as often as the two other techniques discussed above in slurry injection jobs. Abou-Sayed et al. (2002) describe the process as sending a pressure pulse down the well from the surface and then measuring the resulting series of waves that return to the surface. The pressure oscillation may make more than one circuit from surface to bottom to surface before the oscillation is fully dampened. The pressure pulses are sent before and after injection. Analysis of the changes in wave pattern gives an indication of the size of the fractures that have been created. Paige et al. $(1992,1993)$ provide more detailed information on this technique. This technique is less likely to give useful results in the case of waste injection, as compared to its use in conventional hydraulic fractures kept open with coarse-grained proppant. Ductile waste material such as shale cuttings tend to block the fracture flow paths as fracture closure occurs, and hydraulic impedance tests would reflect that, giving fracture lengths far smaller than the actual lengths. Also, fracture flow impedance tests can give no information about orientation and shape of the fracture.

\section{Deep Well Treatment and Injection Program}

ARCO (1994) and Keck and Withers (1994) describe the 1993 Deep Well Treatment and Injection field research program, designed to demonstrate that hydraulic fracturing could be used for disposing of solid wastes underground. The primary goals of the project were to demonstrate the slurry injection technique, monitor fracture growth in real time during the injection cycles, and compare the predicted to actual fracture dimensions.

Rather than using any specific waste, ARCO prepared an inert simulated waste consisting of 4 million pounds of sand and bentonite clay mixed with $50,000 \mathrm{bbl}$ of water. The slurry was injected into a sand layer between 4,426 and 4,614 feet deep at a site in eastern Texas. Injection occurred in four cycles: a 3-hour water-only injection cycle to collect data, and three waste slurry injection cycles operating continuously for 20 to 28 hours each. 
The monitoring devices used in the project included radioactive and temperature tracers, tiltmeters, microseismic monitoring, and hydraulic impedance testing. Different radioactive tracers were added to each of the three waste injection batches. Logs were run following each injection cycle, and then again after the well bore was cleaned out at the end of the project. Each logging run showed the presence of the tracer, but no measurable tracer materials were found above the perforated interval in any of the runs. It was noted, however, that because only the last $10 \%$ of sand in each batch was tagged, it is possible that the fracture extended vertically into areas not indicated by the tracer.

Temperature logs were run before injection began and after each injection cycle. The results suggested that the fracture is present throughout the perforated interval but do not allow calculation of the top or bottom of the fracture.

Twenty-six 15-foot-deep tiltmeter holes were drilled at distances from 800 to 2,100 feet from the injection well. The depth of injection ( $\sim 4,500$ feet) was at the outer limits of the signal strength that a surface tiltmeter could detect at that time. Tiltmeter performance was further confounded because the first large rainstorm in many days occurred just before the first injection cycle, resulting in significant background noise. These factors limited the success of the results to estimating the fracture azimuth. The height and length of the fracture could not be determined accurately.

Hydraulic impedance data were collected six times during the project, and 21 different pressure pulses were generated. The results predicted fractures that were much smaller than would have been necessary to accommodate the large volume of injected material. Therefore, these results were not considered to be accurate.

The microseismic monitoring system consisted of two dedicated monitoring wells located on the predicted azimuth axis. Each well contained a string of 75 geophones that covered a vertical range of about 700 feet. During the injection cycles, approximately 2,400 microseismic events were recorded. These data provided very good information about the length and height of the fractures and represented the most accurate of the monitoring devices used in this project.

Predictions of the fracture dimensions were modeled with two pseudo-three-dimensional models: STIMPLAN and WasteFrac. Both models showed similar results and both agreed reasonably well with the data collected from the microseismic monitoring system. The project met the three goals described earlier and provided substantial useful information on slurry fracture monitoring.

\section{The Mounds Project}

In 1998, a group of organizations undertook a joint research project to document what happens underground during a series of intermittent slurry injection cycles. The goal of the project was to verify or disprove the disposal domain concept. The results of the project, the Mounds Drill Cuttings Injection Field Experiment, provide the best publicly available set of data on fracturing resulting from slurry injection. The results have been published in a variety of venues, including 
a compact disk (CD) available from the Gas Technology Institute (known then as the Gas Research Institute, or GRI - [GRI 1999]), a series of papers at the $37^{\text {th }}$ Rock Mechanics Symposium in 1999 (Moschovidis et al. 1999; Griffin et al. 1999; Warpinski et al. 1999; Wright et al. 1999) and other publications (Moschovidis et al. 2000; Griffin et al. 2000; Warpinski and Engler 2001).

The Mounds site is located about 24 miles south of Tulsa, Oklahoma. The project began by drilling three wells, one for injection and two for monitoring. The injection well was completed into two target formations: the Atoka shale and the Wilcox sand. A series of small-volume batches (about $50 \mathrm{bbl}$ each) of water, mud, and cuttings slurry was first injected into the Wilcox sand through open-hole injection at 2,720- to 2,785-foot depth. Injection lasted from 10 to 20 minutes and was followed by an 80- to 100-minute resting period to allow the fractures to close. After 17 batches had been injected into the Wilcox sand, the lower completion was plugged, and perforations were made at 1,940 to 1,960 feet into the Atoka shale. An additional 20 batches of slurry were injected into the Atoka shale.

The injection trials were heavily monitored. Some of the slurry batches were tagged with a variety of tracers (radioactive, colored dyes, solid glass microspheres, and isotope markers). Radioactive and imaging logs were run. Following completion of the injection trials, the researchers collected cores through the injection formations. These cores were analyzed for the presence of the other types of tracers. An array of 20 surface tiltmeters was positioned around the injection well at about a 30-foot depth. An array of 8 downhole tiltmeters bracketing the formation receiving the injection batches was installed in one of the monitoring wells. An array of 5 microseismic monitors bracketing the formation receiving the injection batches was installed in the other monitoring wells.

The results (as described in Moschovidis et al. 2000) are summarized below:

1. Multiple fractures were created and observed in the core samples.

2. The length and height of fractures were reduced by following an intermittent injection regime.

3. The injection pressure remained stable and repeatable, suggesting that fractures were confined to a limited area (the disposal domain).

4. When larger injection batches were tried, the injection pressure decreased, suggesting that those individual fractures had extended outside of the disposal domain.

5. The core samples showed evidence of multiple fractures. The fractures could be related to hydraulic fracturing during injection and not to other types of rock stress. Some of the fractures in the cores had thin layers of slurry that lined the walls. 
6. Microseismic and tiltmeter (surface and downhole) monitoring gave evidence consistent with the fractures observed in the cores. These monitoring devices proved to be effective in mapping the fractures associated with even small batches of slurry.

7. Formation micro-imager logs correlated well with the fractures observed in the cores. They aided in fracture assessment in some areas where the cores had been damaged during collection.

8. The various types of tracers provided only limited useful information.

9. The fracture simulation models predicted fracture dimensions within an acceptable range of accuracy for waste disposal operations.

10. The project met its goals and demonstrated that intermittent injection can create a disposal domain. 


\section{CHAPTER 6 - DISCUSSION OF RESULTS FROM DATABASE}

\section{Introduction}

One of the goals of Argonne's evaluation of slurry injection technology was to identify as many examples of slurry injection jobs as possible and to compile information about them into a database where they could be readily compared and analyzed. The data were collected through extensive literature review and through correspondence with oil and gas producers, service companies, and a regulatory agency. It is possible that some of the injection jobs included in the database involved injection below fracture pressure, although they were not specifically identified as such by the sources of our information (Ginn 2003). The full database is included as Appendix A. This chapter discusses and summarizes the results of the data in the database. The database includes the following information:

- site name and location,

- name of operator and service company performing the injection,

- geology of the injection formation and confining layers,

- type of injection process,

- depth of injection formation and injection perforations/annular injection depth,

- dates and duration of injection,

- injection rate and pressure,

- types and volumes of materials injected,

- slurry properties,

- preinjection treatment or processing,

- problems experienced,

- costs,

- other comments, and

- sources of information.

Information is not available for each data element for all injection jobs, because most literature references and the large number of entries received from the Alaska Oil and Gas Conservation Commission (Regg and Maunder 2003) only included some of the desired data elements. Much of the unpublished information received directly from companies also did not include all desired data elements. Jobs with incomplete information and potentially some subfracture injection jobs were included nevertheless, because the greatest value of the database is the accumulated total weight of evidence contained therein. Even though the database is incomplete, it is believed to represent the most comprehensive publicly available source of information on the drilling waste slurry injection jobs that have been conducted around the world. As noted in the opening chapter, none of the data included in the database were directly measured or verified by the authors. Information was used as received from companies or as reported in the literature. 


\section{Number of Injection Jobs}

Ideally this database would include information on all injection jobs that have ever been undertaken. However, that is not practical because much of the information is either no longer available in company records, or the companies holding the data are unwilling to share it publicly. Obtaining much of this information was a significant challenge involving several years of urging companies to share their data. Data were welcomed in almost any form as long as they contributed to the knowledge pool in the database.

The database has 334 records. Not every record carries equal weight. While this property of the database is undesirable, it is an unavoidable artifact of the original data sources. For example, there are 37 separate records for annular injection jobs in the Alpine field and 78 more annular injection jobs in the Kuparuk field on the North Slope of Alaska, with each record reflecting a single well that was used to inject cuttings for a period of several weeks to several months. This is an ongoing process, with more such wells anticipated as long as drilling continues in those areas. In comparison, the single record for Statoil's injection at the Asgard platform in the North Sea represented a composite of information from nine injection wells. This information was obtained from a published paper and did not distinguish the results of each well individually. Numerous other records for offshore platforms also summarize the injection that has taken place sequentially into a series of wells.

Most of the injection jobs included in the database used annular injection (296 jobs, or more than $88 \%$ ), while $36(11 \%)$ of the jobs used dedicated injection wells with tubing and packer. These figures reflect the large number of annular injection jobs reported for Alaska (121 jobs, or more than one-third of all the reported jobs).

Although the database includes just a portion of all the injection jobs ever conducted, it offers sufficient data to inform readers of the trends in slurry injection practices and demonstrates that slurry injection is a worldwide waste management practice.

\section{Location of Slurry Injection Jobs}

The database lists the injection jobs alphabetically by location. Locations are summarized in Table 3. The areas with the most representation in the database are the North Slope of Alaska (129 records), the Gulf of Mexico (66 records), , and the North Sea (35 records). This distribution gives a good indication of where slurry injection is being practiced. However, keep in mind that only published data or data supplied by companies are included in the database. The observed distribution does not necessarily indicate that areas not listed or areas showing weak representation do not use slurry injection. All that can be concluded is that no information was available on injection in those areas. For example, some of the major oil producing regions or countries (e.g., Middle East, Nigeria, Far East, Australia) are not represented at all or are poorly represented. 


\section{Who is Doing the Injection?}

Most slurry injection jobs have been conducted by large oil and gas companies and international service companies. The operators of the wells listed in the database include many of the major international companies, or for injection jobs conducted prior to corporate mergers, their premerger component companies. Ten large multi-national companies (Arco, BP, Chevron, ExxonMobil, Conoco, Marathon, Mobil, Phillips, Shell, and Unocal or their pre-or post-merger versions) account for $236(70 \%)$ of the entries. Slurry injection has also been practiced by smaller companies in selected parts of the world.

Table 3 - Locations of Slurry Injection Jobs Based on Records in Database

\begin{tabular}{|l|l|}
\hline Location & Number of Records in Database \\
\hline Alaska & 136 (North Slope 129, other 7) \\
\hline Gulf of Mexico & 66 \\
\hline California & 18 \\
\hline Other U.S. onshore & 28 (Louisiana - 20, Texas - 6, Oklahoma - 1, North Carolina - 1) \\
\hline North Sea & 35 \\
\hline Canada & 9 (Alberta - 4, Saskatchewan - 3, Nova Scotia offshore - 2) \\
\hline Latin America & 4 (Argentina - 1, Mexico - 2, Venezuela - 1) \\
\hline Asia & 20 (India - 17, Indonesia - 1, Russia/Sakhalin - 1, Thailand - 1) \\
\hline Africa & 17 (Tunisia - 14, Egypt - 2, Chad - 1) \\
\hline U.K. onshore & 1 \\
\hline Total & 334 \\
\hline
\end{tabular}

Many of the records obtained from literature reports did not mention the service companies that worked with the operators to do the slurry injection. Only a few current service companies work extensively in the slurry injection field. Although the authors attempted to contact all qualified service companies to obtain data on injection jobs, only three companies - Apollo Services, $\mathrm{MI} / \mathrm{SWACO}$, and Terralog Technologies - supplied data that were used in the database.

Other operators and service companies are probably involved with slurry injection. However, they are not included in the database because they did not make any information available to Argonne or have not published information in the readily available literature. 


\section{Geological Information}

Many of the records were weak on geological information. One general rule of thumb was discussed in an earlier chapter: most annular disposal wells inject into low permeability shale or mudstone formations and most dedicated completed injection wells inject into high permeability sands or sandstones. There are some examples that do not follow that general trend. For example, the injection at two North Sea platforms (Eldfisk and Ekofisk) used a tubing and packer configuration yet injected into a Hordaland Group sequence of shales and claystones.

Conversely, operators at another North Sea platform, Brent, used annular injection to inject into the Hutton sand layer.

Many of the records that included geological information indicated a mixed geological profile of alternating sand and shale layers. This is an ideal situation that allows for better vertical control of fracture growth.

\section{Injection Depth}

Only about 70 of the records indicated the depth at which the slurry was injected. To the extent possible, the true vertical depth was expressed. Table 4 shows the number of injection jobs done in different depth ranges. Most injection jobs were done at depths shallower than 5,000 feet, with many falling between 2,501 and 5,000 feet. The shallowest injection depth reported was 1,246 to 1,276 feet at Duri, Sumatra in Indonesia and the deepest was 15,300 feet at an onshore well at Duson, Louisiana.

Table 4 - Distribution of Injection Depths in Database

\begin{tabular}{|l|c|}
\hline $\begin{array}{l}\text { Depth Range } \\
(\mathrm{ft})\end{array}$ & $\begin{array}{c}\text { Number of Records } \\
\text { in Database }\end{array}$ \\
\hline$<2,500$ & 14 \\
\hline $2,501-5,000$ & 36 \\
\hline $5,001-7,500$ & 8 \\
\hline $7,501-10,000$ & 2 \\
\hline$>10,000$ & 3 \\
\hline
\end{tabular}

\section{Duration of Injection}

It is very difficult to generalize this type of information, partly because there is a wide range in duration of an injection campaign, but also because of the manner in which the data were reported. As noted above, some records clearly describe short-term injection into a single well, 
while others offer a composite view of multiple injection wells at a single platform or location. A few of the records list only a single month in the duration column. Presumably, this means that the total injection campaign described in that record was completed within the month. Many other records list a duration of several months to several years. The longest duration reported in the database for the same well is at the THUMS man-made island off the coast of Long Beach, California. The database reports that the injection began in 1994 and is ongoing. Regg and Maunder (2003) report that annular disposal through a series of wells in Alaska's Kuparuk Field began as early as 1984 and continues today. Dedicated grind and inject operations have been conducted since at least 1990 for real-time drilling waste disposal (well CC-02A in western Prudhoe Bay).

\section{Injection Rate}

The injection rate was reported in only about 90 of the records. Many of these reported a range of injection rates. Nearly all of these records indicated that the lower end of the injection range was $5 \mathrm{bbl} / \mathrm{min}$ or less, and more than half were $2 \mathrm{bbl} / \mathrm{min}$ or less. The lowest reported lower end of a range was $0.3 \mathrm{bbl} / \mathrm{min}$ at the North Sea Asgard platform, while the highest reported lower end of a range was $16.7 \mathrm{bbl} / \mathrm{min}$ at the North Slope Grind and Inject Plant at Prudhoe Bay. Most of the upper ends of the range of injection rates were less than $4 \mathrm{bbl} / \mathrm{min}$. The lowest reported upper end of a range was $1.9 \mathrm{bbl} / \mathrm{min}$ at the Cook Inlet, Alaska, NCIU facility, while the highest reported upper end of a range was $44 \mathrm{bbl} / \mathrm{min}$ at the North Slope Grind and Inject Plant at Prudhoe Bay, Alaska.

\section{Injection Pressure}

Nearly 100 of the records include injection pressure data. About half of all the records showing injection pressure were provided by Apollo Services. All of those pressure data represent surface pressures. The other pressure values reported in the database are not necessarily consistent. In some cases the reported values are surface pressures, while in other cases they are bottomhole pressures. These values will be different for the same well. Unfortunately, for much of the rest of the data entered into the database, which pressure being reported was not identified. If the injection depth is given, a calculation correcting for the hydrostatic head of the waste slurry in the hole can usually be used to decide if the reported injection pressure is bottom-hole or surface.

Like the injection rate, many of the records are expressed as ranges. Nearly all of these records indicated that the lower end of the injection range was 2,000 pounds per square inch (psi) or less, and more than half were 1,200 psi or less. The lowest reported lower end of a range was 50 psi at an onshore well at Duson, Louisiana, while the highest reported lower end of a range was about 3,000 psi at the North Sea Valhall platform.

Most of the upper ends of the range of injection pressures were less than 2,500 psi. The lowest reported upper end of a range was 650 psi at the North Sea Block 22/25 facility, while the highest reported upper end of a range was 5,431 psi at the North Slope Grind and Inject Plant at Prudhoe Bay. This value is a bottomhole pressure. 
In general, if the depth of injection is known, it is usually possible to decide if bottomhole pressure or surface pressure was reported by correcting for the static head in the injection tubing of the injected slurry $(\sim 0.5-0.7 \mathrm{psi} / \mathrm{ft})$ and noting that the fracture gradient is on the order of 0.8 $0.9 \mathrm{psi} / \mathrm{ft}$ in most deep environments (greater than 5,000 feet), and 1.0-1.2 psi/ft in shallow (less than 5,000 feet) long-term injection operations. One would expect the bottom hole injection pressure to be equivalent to a fluid density of from 14 to $18 \mathrm{ppg}$, assuming that fracturing was taking place.

Ginn (2003) notes that 5 of the 6 injection jobs reported for onshore Texas may be injecting below fracture pressure. The original source of data for those wells (Apollo Services 2002) did not provide any pressure data.

\section{Type and Volume of Material Injected}

Most of the wells in the database injected drill cuttings. Many also injected other types of wastes; these are discussed at the end of Chapter 3.

Injected volume was one of the data fields that was best reported in the database. All but two of the records indicated the volume of material injected, although volume was reported in different, and not always consistent, ways. Some records indicated the daily or monthly volume, while others reported the total volume going into that well. Many of the injection jobs described in the database were still ongoing at the time the information was either published or sent to Argonne; therefore, the volume reported is an underestimate of the final total volume. Another way in which the reported data varies is in whether the value is total slurry or just the solids used to make a slurry. Often the reported data were not clearly indicated as one or the other of these options.

Table 5 shows the number of records that reported volumes within specified ranges. For the purpose of this table, data are assumed to represent total slurry volume. The data show that more than $83 \%$ of the injection jobs in the database involved less than $50,000 \mathrm{bbl}$ of slurry. The largest job reported in the database is more than 43 million bbl of slurry injected in several North Slope Grind and Inject projects at Prudhoe Bay.

\section{Slurry Properties}

Table 2 in Chapter 3 summarizes the slurry properties reported in the database. The percentage of solids ranged from 5 to $70 \%$, with most values lying between 10 and $26 \%$. The specific gravity ranged from 1.03 to $1.8 \mathrm{~g} / \mathrm{cm}^{3}$, but the majority of values were in the range of 1.15 to 1.5 $\mathrm{g} / \mathrm{cm}^{3}$. The density ranged from 8.3 to 13.3 pounds per gallon (lb/gal), although most values fell within the range of 8.6 to $11.5 \mathrm{lb} / \mathrm{gal}$. (Note that the density of water is about $8.3 \mathrm{lb} / \mathrm{gal}$ [0.43 $\mathrm{psi} / \mathrm{ft}$ of pressure head in the tubing]). The viscosity ranged from $42-110$ seconds/quart (Marsh Funnel viscosity), with most values falling in the range of 50-90 seconds/quart. 
Table 5 - Distribution of Total Slurry Volume in Database

\begin{tabular}{|l|l|}
\hline \multicolumn{1}{|c|}{ Total Reported Slurry Volume (bbl) } & Number of Records in Database \\
\hline$<10,000$ & 87 \\
\hline $10,000-50,000$ & 206 \\
\hline $50,001-100,000$ & 9 \\
\hline $100,001-500,000$ & 13 \\
\hline $500,001-1,000,000$ & 5 \\
\hline$>1,000,000$ & 12 \\
\hline Total & 332 \\
\hline
\end{tabular}

\section{Pre-Injection Processing or Treatment}

Chapter 3 discusses the types of processing that must take place. First muds and cuttings are separated and the cuttings are transported to the slurrying system. The cuttings are mixed with a liquid to make a slurry. At offshore locations, seawater is typically used and at onshore locations, a water supply must be available. The slurry is processed through various particle-size reduction devices, and viscosifiers are added as needed to generate a slurry with the desired characteristics. For those records that describe the solids processing, centrifugal pumps with hardened edges on the impeller are the most common means of reducing the particle size and blending the slurry. In some cold weather operations, like the North Slope Grind and Inject Plant at Prudhoe Bay, solids have to be thawed before they can be ground and slurried.

\section{Problems Experienced}

Problems were reported in only about 30 of the records. Some of the problems were operational ones that caused the injection process to slow or stop, while others were environmental problems that led to leakage of fluids to the ground surface or the sea floor (also referred to in some records as broaching or breeching).

The most common operational problem was plugging of the casing or tubing because solids had settled out. The causes of this problem included:

- using slurries with inappropriate viscosity,

- operating at too slow an injection rate,

- failing to clear the well bore with a clean water flush at the end of an injection cycle,

- power failures that interrupted injection cycles, and

- allowing pressure to drop at the end of an injection cycle so that solids could flow back into the well bore from the formation. 
By avoiding these situations, operators were able to eliminate this type of problem.

Another important operational problem was excessive erosion of casing, tubing, and other components of the system. It is not surprising that metal components show wear at higher than normal rates when solid slurries are pumped through them at high pressure. Operators learned from this experience and were able to substitute tubulars with high burst strength and to use specially hardened alloys for critical parts in the pumping system.

Two other operational problems dealt with surface handling issues. In some cases, the injection was unable to keep up with the drilling rate and cuttings had to be stockpiled. This situation is merely inconvenient at onshore locations, but can cause drilling to stop at offshore locations when insufficient storage capacity is available. Finally, in some cases, onsite personnel added inappropriate materials to the waste stockpile. These materials either damaged solids processing equipment or created conditions not conducive to smooth operations. For example, shredded solid wastes (presumably trash or debris) clogged screens at a Gulf of Mexico rig (East Cameron 56 JB-3).

Although the operational problems are inconvenient and costly to operators who have to stop their normal activities, environmental problems are of much greater concern. Unanticipated leakage to the environment not only creates a liability to the operator, but it also generally results in a short-term to permanent stoppage of injection at that site. Further, whenever injection jobs result in leakage, the confidence of regulators who must approve the practice will be diminished. Several of the largest injection jobs reported have resulted in leakage. During the pilot phase, the large Grind and Inject Plant at Prudhoe Bay operated continuously for portions of 3 years. In 1997, fluids were observed broaching to the surface at multiple locations near the injection well. Injection was stopped and leaked fluids were collected for disposal. After 4 days and a total volume of 18,000 bbl, flow to the surface stopped. Several days later, low-rate injection was started to clean up the Grind and Inject Plant. No additional broaching was observed at this point. The cause of the broaching was believed to be intersection of the injection plume with other nearby uncemented well bores that lead to the surface. The project demonstrated that slurry injection is effective in disposing of large volumes of drilling waste but also highlighted the need for absolute well bore integrity. The incident occurred during the demonstration phase of the technology. The operators of the Grind and Inject Plant drilled three new dedicated injection wells designed and constructed to minimize the potential for communication of fluids. No other wells are located within 1 mile of the injection wells. No similar problems have been experienced with the new wells.

Leakage can occur at offshore sites too. At the North Sea Asgard platform, several wells showed leakage at the sea floor. This leakage was presumed to be due to poor cementing jobs. In some wells, the leakage stopped after fractures were allowed to heal, but in other wells, injection was discontinued.

Although not included in the database because no specific data are available, the Louisiana Department of Natural Resources has reported that since 1997 they have received 13 reports of small onshore annular injection jobs that have leaked to the surface (Wascom 2002). Although 
most of the reported breaches occurred near the wellhead, one case involved leakage of $500 \mathrm{bbl}$ of material to the surface about 4,000 feet from the wellhead. The most likely cause of these leakage events and those described in the previous paragraph is that the fracture reaches a well bore that has not been properly cemented. Under the high downhole pressure, the fluids will seek out the pathway of least resistance. If cracks in the cement job or geological faults are available, the fluids can preferentially migrate upward and may reach the land surface or the sea floor. Needless to say, if there is a breach in the casing where annular injection is occurring, the slurry, or some portion of it, will go out the breach, rather than be fractured into the rocks at the greater depth of the shoe.

The long-term injection program at the THUMS island in California has experienced pressure increases in the injection zone. Fortuitously, the injection well was planned for injection into a series of sand layers. When the pressure rose to unacceptable levels, the operators closed in the lowermost perforations, moved up the well to the next lowest sand formation, and recompleted the well.

\section{Other Databases}

It is possible that some of the operators and service companies maintain detailed proprietary databases of their previous and ongoing injection jobs. With one exception, Argonne was unable to obtain any detailed databases, but did receive some summary tables from several service companies. The exception is an extremely detailed database of eight injection jobs prepared by Terralog Technologies for the DOE (Terralog 2002b). Those eight jobs included more than 700 individual injection cycles. Data were compiled continuously at intervals of 5 seconds to 5 minutes. The information is available in a Microsoft Access database format and includes utilities for graphing and plotting the data. The level of detail in the Terralog database is many times greater than the Argonne database, but the Argonne database contains summary information on many more facilities. Both databases are useful in helping to understand the slurry injection process.

One other reference obtained during preparation of this report, while not a true database, provides useful information on slurry injection (Buller 1996). That report compiles the responses of numerous industry slurry injection practitioners in the mid-1990s to an extensive questionnaire on how slurry injection operations were conducted. The report is apparently the product of a joint industry project. Portions of the useful information it contains have been published in public venues, but much of its information has not. The value of that report is its compilation of information from various industry sources. 


\section{CHAPTER 7 - ECONOMIC CONSIDERATIONS}

The previous chapters describe slurry injection technology and demonstrate that it works well in many applications. However, no technology will be used widely unless it is cost-effective. Cost information is quite useful, but only a few of the records in the database report any cost data. All but one of these are literature citations; typically companies that provided data to Argonne were reluctant to share cost information. Some of the cost data describe the absolute costs of injection, while other records provide a comparison of injection costs with the costs of other disposal methods.

Ideally, costs would be compared on an equal footing. But costs escalate over time such that a dollar spent in 1990 is more valuable today than a dollar spent today. The data discussed here were not itemized by year and could not be adjusted to a common baseline year. Therefore, comparisons are approximate.

\section{Absolute Costs}

At the North Sea Brent platform, the field average disposal cost for injected slurry is about $£ 17 / \mathrm{bbl}$ (Brakel et al. 1997). The year in which the expenditures were made was not available, so precise conversion of currencies is not possible. Just for the sake of discussion, the exchange rate as of January 1,1997 , was $£ 1=\$ 1.71$. At Marathon's mobile grind and inject plant in the Kenai region of Alaska, disposal costs range from $\$ 3 / \mathrm{bbl}$ to $\$ 20 / \mathrm{bbl}$ during the year. This range is the result of higher costs associated with winter operations (heating, labor, and reduced efficiency). Marathon has reduced its average injection costs by $73 \%$ from $\$ 53.62 / \mathrm{bbl}$ in 1995 to $\$ 14.73 / \mathrm{bbl}$ in 2002 . Since the inception of the injection program, disposal costs have totaled $\$ 9.0$ million (Susich 2002).

Hardy and Khatib (1996) report on the first injection of NORM wastes permitted in the Gulf of Mexico in 1992. Shell's costs for disposing of NORM waste at an onshore commercial disposal facility ran as high as $\$ 350 / \mathrm{bbl}$. Shell investigated three increasingly cost-effective methods for slurry injection of NORM wastes into a depleted well bore in the Eugene Island field. Although Hardy and Khatib do not provide actual costs, a recent communication from Shell indicates that over a 4-year period, about 4,200 bbl of NORM waste was injected, and the cost declined from $\$ 1,200 /$ bbl to $\$ 125 /$ bbl (Satterlee 2003).

\section{Comparative Costs}

Most of the cost reports provide injection costs relative to other disposal costs - typically the costs of collecting the drilling wastes at offshore facilities and hauling them to shore. Most of these comparisons favor slurry injection, but others suggest that slurry injection is more costly than other methods. The cost comparisons can be only approximations because they do not necessarily include the same types of costs. Slurry injection has certain fixed costs, but also can avoid costs for items like rental of cuttings boxes and work boat time. Examples favoring slurry injection include: 
- Kunze and Skorve (2000) indicate that at the Jotun B platform in the North Sea, a dedicated injection well would cost $\$ 3.5$ million, annular injection would cost $\$ 3.0$ million, onshore disposal would cost $\$ 7.7$ million, and using synthetic muds and discharging the cuttings to the ocean would cost $\$ 5.9$ million.

- Minton (1996) discusses slurry injection on the Ula platform in the North Sea. The cost of fabricating and commissioning the slurry injection unit was about $\$ 270,000$. The cost savings in the first year of injection operations was more than $\$ 3.3$ million compared to using synthetic-based muds.

- Moschovidis et al. (1993) report that slurry injection at the Valhall platform in the North Sea offers a cost savings of $\$ 550,000$ per well over onshore disposal.

- Hainey et al. $(1997,1999)$ offer detailed cost projections relating to the THUMS facility in California. They project that slurry injection of drilling wastes saves $\$ 450,000$ per year over landfill disposal. Assuming that a recompletion of the injection well is needed each year at $\$ 200,000$, the net savings is still $\$ 250,000$ per year.

- Hagan et al. (2002) reported that waste disposal costs at the Wytch Farm site in the United Kingdom were reduced from $\$ 600,000$ per well to $\$ 270,000$ per well when slurry injection was used.

- Malachosky et al (1991) report waste disposal cost savings of $\$ 75,000$ to $\$ 225,000$ per well for four Gulf of Mexico wells. These were some of the earliest slurry injection jobs reported in the literature.

To confound the cost-effectiveness picture, several other references reported that slurry injection was more costly than other disposal methods, although their conclusions need to be examined in the context of each individual situation. Examples are listed below:

- Louviere and Reddoch (1993) describe a slurry injection job in the East Cameron field in the Gulf of Mexico. The operator had estimated that injection costs would be $\$ 112,000$ compared to onshore disposal costs of $\$ 19,510$. However, the drilling process took longer than anticipated, and the delays resulted in more equipment rental time than projected. The final total injection cost was $\$ 294,625$, with an estimated cost for onshore disposal of the wastes from the extended drilling period of $\$ 46,067$. The authors of that paper offer additional justification for the higher cost of the injection option: fewer cuttings boxes must be handled, thereby avoiding boat loading and transport delays associated with bad weather.

- Schuh et al. (1993) offer comparative costs for the Murdoch platform in the North Sea. The cost for injection was $£ 859,000$, while the cost for cleaning and discharging cuttings was $£ 630,000$. Just for the sake of discussion, the exchange rate as of January 1,1993 , was $£ 1=$ $\$ 1.52$. Schuh et al. (1993) suggest that injection costs could have been reduced because they 
believe the facility was over-engineered and that the number of personnel used for this trial was higher than would be needed for long-term operations. With more experience, the injection option could become the more cost-effective option.

- Holt et al. (1995) describe a slurry injection program in the Gulf of Suez in Egypt. The average injection costs were $\$ 24 / \mathrm{bbl}$. At this location, the cost for onshore disposal was quite low, about $\$ 8 / \mathrm{bbl}$.

- Nagel and Strachan (1998) present similar cost comparison data to the Kunze and Skorve (2000) and Minton (1996) papers discussed above. However, Nagel and Strachan find that at the Ekofisk field in the North Sea, using oil-based muds and injecting the cuttings would cost $\$ 39$ million; using synthetic-based muds and discharging the cuttings to the ocean would cost $\$ 37.7$ million; and onshore disposal would cost \$ 94.9 million. In this example, the costs of injecting or discharging are very close, and operational or heath, safety, and environmental factors may tip the balance one direction or the other. As an example of environmental factors related to slurry injection, Saasen et al. (2000) offer evidence that the carbon dioxide emissions from slurry injection of oily cuttings are far lower than the emissions associated with hauling the cuttings back to shore for disposal.

- James and Rørvik (2002) also offer cost comparison data for the Eldfisk Alpha 2/7A platform in the Ekofisk field in the North Sea. They show costs of $\$ 477 /$ metric ton for onshore disposal, and $\$ 1,070 /$ metric ton for slurry injection when the cuttings from just one well are injected. However, within this absolute cost figure, there is a fixed capital cost component and ongoing operational costs. As the volume of wastes that is injected increases, the share per unit of the capital costs declines, thereby reducing the total cost per unit. James and Rørvik show that slurry injection costs decline significantly to $\$ 390 /$ metric ton when the cuttings from three wells are injected. If the wastes from more than three wells are injected, the unit cost of slurry injection would decline even more and show a cost advantage over onshore disposal.

- The important principle of economy of scale is echoed by Sirevåg and Bale (1993). They report that the capital cost of installing the slurry injection unit was about $\$ 900,000$. Injection of the cuttings from one $81 / 2$-inch section of well resulted in a savings of $\$ 233,000$. Assuming that comparable cost savings result from other wells, four additional wells would need to be drilled to make the investment in slurry injection pay off.

\section{Further Thoughts on Costs}

The examples described above show a range of cost comparisons between using lower cost oilbased muds and injecting the cuttings, using synthetic-based muds and discharging the cuttings, and hauling wastes to shore for disposal. No option was always the least costly nor was any option always the most costly. This points out the importance of conducting a site-specific cost/benefit analysis. 
Three critical factors in determining the cost-effectiveness of slurry injection are:

- The volume of material to be disposed of - The larger the volume, the more attractive injection becomes in many cases. The ability to inject onsite avoids the need to transport materials to an offsite disposal location. The transportation cost component can be very important for large volumes of material. In addition, transporting large volumes of waste introduces risks associated with handling, transferring, and shipping. Transportation also consumes more fuel and generates additional air emissions.

- The regulatory climate - If cuttings can be discharged at a reasonable treatment cost, then discharging is often attractive. For example, the EPA allows Gulf of Mexico operators to discharge synthetic-based cuttings as long as certain standards can be met. In the North Sea and in Alaskan waters, heavy restrictions or prohibitions have been placed on discharging synthetic-based cuttings. Regulatory requirements that prohibit or encourage slurry injection play an important role in selection of disposal options. North Sea locations predominate the examples listed above, showing that injection has been evaluated seriously at many North Sea locations.

- The availability of low-cost onshore disposal infrastructure - Several disposal companies have established extensive networks of barge terminals along the Louisiana and Texas coasts to collect large volumes of wastes brought to shore from offshore Gulf of Mexico platforms and subsequently inject them using either subfracture injection or salt cavern disposal at onshore locations. Through the economy of scale, the onshore disposal costs are not high. Much of the offshore waste that cannot be discharged is brought to shore and disposed at these facilities. Most other parts of the world (the Gulf of Suez example above notwithstanding) do not have an effective, low-cost onshore infrastructure. Thus, in those locations, onshore disposal is often a more costly alternative. 


\section{ACKNOWLEDGMENTS}

The funding to support this project was provided by the U.S. Department of Energy, Office of Fossil Energy, National Petroleum Technology Office (NPTO), under Contract W-31-109-Eng38. John Ford is the NPTO project manager for this work. We acknowledge his support of our efforts.

Many persons and companies contributed information to the database. We particularly thank Mike Bruno of Terralog Technologies, Joel Sogne of Apollo Services, Reg Minton and Steve Simmons of MI-SWACO, Mark Susich of Marathon Oil, Lisa Pekich of ConocoPhillips, Richard Keck of Natchiq Technical Services, and Stuart Wittenbach of Kerr-McGee. We appreciate the extensive comments on the draft report and additional entries for the database provided by Jim Regg and Tom Maunder of the Alaska Oil and Gas Conservation Commission.

This report and the companion regulatory compendium are part of a larger project on exploration and production waste management that is being coordinated through the Petroleum Environmental Research Forum (PERF). PERF was instrumental in advocating that DOE should support this work.

Co-author Maurice Dusseault is an extended-staff, part-time employee of Argonne National Laboratory. 


\section{REFERENCES}

Abou-Sayed, A.S., and Q. Guo, 2001, "Design Considerations in Drill Cuttings Re-Injection Through Downhole Fracturing," IADC/SPE 72308, presented at the IADC/SPE Middle East Drilling Technology Conference, Bahrain, October 22-24.

Abou-Sayed, A.S., and Q. Guo, 2002, "Drilling and Production Waste Injection in Subsea Operations - Challenges and Recommendations," OTC 14288, presented at the 2002 Offshore Technology Conference, Houston, TX, May 6-9.

Abou-Sayed, A.S., Q. Guo, G. Wang, J.D. McLennan, and K. Zaki, 2002, “Challenges for Monitoring and Verification of Drill Cuttings Reinjection Performance," presented at the SPE/ISRM Rock Mechanics Conference, Irving, TX, October 20-23.

Andersen, E.E., R.J. Louviere, and D.E. Witt, 1993, “Guidelines for Designing Safe, Environmentally Acceptable Downhole Injection Operations," SPE 25964, presented at SPE/EPA Exploration \& Production Environmental Conference, San Antonio, TX, March 7-10.

API, 2000, "Overview of Exploration and Production Waste Volumes and Waste Management Practices in the United States," prepared by ICF Consulting for the American Petroleum Institute, Washington, DC, May.

Apollo Services, 2002, information on selected Apollo slurry injection projects, provided by J. Songne, Apollo Services, Lafayette, LA, a subsidiary of Baker Hughes Inteq, to J.A. Veil, Argonne National Laboratory, June 28 and December 12.

ARCO, 1994, "The Deep Well Treatment and Injection Program - Fracture Technology Field Demonstration Project," prepared by the Atlantic Richfield Corporation, 84 pp., April 22.

Baker, B.D., J.M. Englehardt, and J.D. Reid, 1999a, "Large Scale NOW/NORM Disposal Through Slurry Waste Injection," SPE 53821, presented at the 1999 Latin American and Caribbean Petroleum Engineering Conference, Caracas, Venezuela, April 21-23.

Baker, B.D., J.M. Englehardt, and J.D. Reid, 1999b, "Large Scale NORM/NOW Disposal Through Slurry Waste Injection: Data Analysis and Modeling," SPE 56491, presented at the SPE Annual Technical Conference and Exhibition, Houston, TX, October 3-6.

Bilak, R.A., M.A. Parsons, and I. Januar, 2002, "Implementation of a Deep Well Disposal Technology for E\&P Wastes in Indonesia,” SPE 73842, presented at the SPE International Conference on Health, Safety and Environment in Oil and Gas Exploration and Production, Kuala Lumpur, Malaysia, March 20-22. 
Brakel, J.D., J.B. Davies, G.K Yule, and J.T.O. Thornton, 1997, "Cuttings Re-Injection in Brent Reduces Drilled Cuttings Discharge to Sea," SPE 37864, presented at the 1997 SPE/UKOOA European Environmental Conference, Aberdeen, Scotland, April 15-16.

Branagan, P.T., N.R. Warpinski, B.P. Engler, and R. Wilmer, 1996, "Measuring the Hydraulic Fracture-Induced Deformation of Reservoir and Adjacent Rocks Employing a Deeply Buried Inclinometer Array: GRI/DOE Multi-Site Project," SPE 36451, SPE Annual Technical Conference and Exhibition, Denver, CO, October 6-9.

Brkic, V., and I. Omrcen, 2002, "Disposal of Mercury-Sulfide and Residual Ash by Deep Well Injection," presented at the 2002 Annual Forum of the Ground Water Protection Council, San Francisco, CA, September 22-25.

Brockway, T.A., L. Andrews, S. Caza, and D. Simpson, 2002, "Implementation of an Ultrasonic Cuttings Processing System for Drilling Operations at the Meltwater Field, North Slope Alaska," SPE 76761, presented at the SPE Western Regional/AAPG Pacific Section Joint Meeting, Anchorage, AK, May 20-22.

Bruno, M.S., 2000, “Converting Biosolids to Energy by Deep Well Injection and Biodegradation," presented at the Canadian National Residuals and Biosolids Management Conference, Toronto, Ontario, September 24-26.

Buller, D.C., 1996, “Cuttings Re-Injection: Study of Operation Practice,” prepared by Well Performance Technology, Yately, Hampshire, UK, for British Petroleum as part of a Joint Industry Project, October 31.

Crawford, H.R., and J.A. Lescarboura, 1993, "Drill Cuttings Reinjection for Heidrun: A Study," SPE 26382, presented at SPE Annual Technical Conference and Exhibition, Houston, TX, October 3-6.

Dusseault, M.B., and R.A. Bilak, 1997, "Slurry Fracture Injection for the Disposal of Large Volumes of Low-Toxicity Wastes," Proceedings of the 1st Asian Rock Mechanics Symposium, vol.1, 25-32, Seoul, South Korea, October 13-15.

Dusseault, M.B., and R.A. Bilak, 1998, "Mitigation of Heavy Oil Production Environmental Impact through Large-Scale Slurry Fracture Injection of Wastes," SPE 47217, presented at the SPE/ISRM Eurock '98, Trondheim, Norway, July 8-10.

Dusseault, M.B. and L. Rothenburg, 2002, "Deformation Analysis for Reservoir Management," Oil \& Gas Science and Technology - Revue de l'Institut Français du Pétrole, v 57, N ${ }^{\circ}$ 5, pp 539554.

Dusseault, M.B., R.A. Bilak, M.S. Bruno, and L. Rothenburg, 1994, L., "Disposal of Granular Solid Wastes in the Western Canadian Sedimentary Basin by Slurry Fracture Injection," 
presented at the International Symposium of Scientific and Engineering Aspects of Deep Injection Disposal of Hazardous and Industrial Wastes, Berkeley, CA, May 10-13.

Dusseault, M.B., P.G. Danyluk, and R.A. Bilak, 1998, "Slurry Fracture Injection of Solid and Liquid Heavy Oil Wastes," SPE 46823, presented at the SPE International Conference of Health, Safety and Environment in Oil and Gas Exploration and Production, Caracas, Venezuela, June 710 .

E\&P Forum, 1993, "E\&P Forum Guidelines for the Planning of Downhole Injection Programmes for Oil Based Mud Wastes and Associated Cuttings from Offshore Wells," prepared by the E\&P Forum, London, UK, October.

EPA, 1993, "Development Document for Effluent Limitations Guidelines and New Source Performance Standards for the Offshore Subcategory of the Oil and Gas Extraction Point Source Category,” EPA 821-R-93-003, U.S. Environmental Protection Agency, Washington, DC, January.

EPA, 2000, "Development Document for Final Effluent Limitations Guidelines and New Source Performance Standards for Synthetic-Based Drilling Fluids and Other Non-Aqueous Drilling Fluids in the Oil and Gas Extraction Point Source Category," EPA 821-B-00-013, U.S. Environmental Protection Agency, Washington, DC, December.

EPA, 2002, "Evaluation of Impacts to Underground Sources of Drinking Water by Hydraulic Fracturing of Coalbed Methane Reservoirs," draft EPA 816-D-02-006, U.S. Environmental Protection Agency, Washington, DC, August.

Ferguson, G.C., R.C. Minton, S. Cow, and B.W. Secoy, 1993, "Subsea Cuttings Injection Guide Base Trial," SPE 26681, presented at the Offshore European Conference, Aberdeen, Scotland, September 7-10.

Gidley, J.L., S.A. Holditch, D.E. Nierode, and R.W. Veatch, 1989, "Recent Advances in Hydraulic Fracturing," Monograph Vol. 12, Society of Petroleum Engineers, Richardson, TX.

Ginn, R.F., 2003, electronic mail message containing comments on February 6, 2003, draft version of this report from Ginn, Railroad Commission of Texas, Austin, TX, to J. Veil, Argonne National Laboratory, Washington, DC, March 7.

Glansbeek, J.H.B., N.R. Avern, and D.T. Simpson, 1998, "Ultrasonic Technology: Creating a New Approach to Drill Cuttings Disposal," SPE 48983, presented at the SPE Annual Technical Conference and Exhibition, New Orleans, LA, September 27-30.

GRI, 1999, "Mounds Drill Cuttings Injection Project," CD containing information about the Mounds project, GRI-99/0173, Gas Research Institute, June. 
Griffin, G.L., C.A. Wright, E.J. Davis, L. Weijers, and Z.A. Moschovidis, 1999, "Tiltmeter Mapping to Monitor Drill Cuttings Disposal," presented at the $37^{\text {th }}$ U.S. Rock Mechanics Symposium, Vail, CO, June 6-9.

Griffin, G.L., C.A. Wright, E.J. Davis, S.L. Wolhart, and Z.A. Moschovidis, 2000, "Surface and Downhole Tiltmeter Mapping: An Effective Tool for Monitoring Drill Cuttings Disposal," SPE 63032, presented at the 2000 SPE Annual Technical Conference and Exhibition, Dallas, TX, October 1-4.

Guo, Q., L.J. Dutel, G.B. Wheatley, J.D. McLennan, and A.D. Black, 2000, “Assurance Increased for Drill Cuttings Re-Injection in the Panuke Field Canada: Case Study of Improved Design," IADC/SPE 59118, presented at the IADC/SPE Drilling Conference, New Orleans, LA, February 23-25.

Hagan, J.T., L.R. Murray, T. Meling, Q. Guo, J.D. McLennan, A.S. Abou-Sayed, and T.G. Kristiansen, 2002, "Engineering and Operational Issues Associated with Commingled Drill Cuttings and Produced Water Re-Injection Schemes," SPE 73918, presented at SPE International Conference on Health, Safety and Environment in Oil and Gas Exploration and Production, Kuala Lumpur, Malaysia, March 20-22.

Hainey, B.W., R.G. Keck, M.B. Smith, K.W. Lynch, and J.W. Barth, 1997, "On-site Fracturing Disposal of Oilfield Waste Solids in Wilmington Field, Long Beach Unit, CA," SPE 38255, presented at the 1997 SPE Western Regional Meeting, Long Beach, CA, June 25-27.

Hainey, B.W., R.G. Keck, M.B. Smith, K.W. Lynch, and J.W. Barth, 1999, "On-site Fracturing Disposal of Oilfield Waste Solids in Wilmington Field, California," SPE 56070, SPE Production and Facilities 14(2) 88-93, May.

Hardy, G.H., and Z.I. Khatib, 1996, "Treatment and Disposal Options for NORM Oil Field Waste," SPE 36586, presented at the SPE Annual Technical Conference and Exhibition, Denver, CO, October 6-9.

Holditch, S.A., 2001, “Hydraulic Fracturing," unpublished white paper prepared for U.S. Department of Energy, National Energy Technology Laboratory, and included as Appendix A of EPA (2002).

Holt, C.A., Jr., H. Prewett, and S. Mansour, 1995, "Oily Drilled Cuttings - A Pro-Active Approach to Protecting the Environment," SPE 29794, presented at the SPE Middle East Oil Show, Bahrain, March 11-14.

James, R.W., and B. Rørvik, 2002, “Total Energy Consumption: A Comparative Case Study of Two Alternative North Sea Cuttings Handling Processes Associated with the Use of Oil Based Drilling Fluids," SPE 73919, presented at the SPE International Conference on Health, Safety and Environment in Oil and Gas Exploration and Production, Kuala Lumpur, Malaysia, March $20-22$. 
Keck, R.G., 1999, presentation made at SPE Cuttings Injection School, slides dated September 9.

Keck, R.G., 2000, “Drill Cuttings and Solid Waste Injection,” lecture used as part of SPE Distinguished Lecturer Program, Powerpoint slides dated April 17.

Keck, R.G., 2002, "Drill Cuttings Injection: A Review of Major Operations and Technical Issues," SPE 77553, presented at the SPE Annual Technical Conference and Exhibition, San Antonio, TX, September 29 - October 2.

Keck, R.G., and R.J. Withers, 1994, "A Field Demonstration of Hydraulic Fracturing for Solids Waste Injection with Real-Time Passive Seismic Monitoring," SPE 28495, presented at the SPE $69^{\text {th }}$ Annual Technical Conference and Exhibition, New Orleans, LA, September 25-28.

Kordzi, J., 1998, “Class I Fracture Slurry Injection - A Summary of the Technology and Recommendation for Implementation," Report No. 1, prepared by the USEPA National Underground Injection Control Technical Work Group, February 26.

Kunze, K.R., and H. Skorve, 2000, "Merits of Suspending the First Platform Well as a Cuttings Injector," SPE 63124, presented at the 2000 SPE Annual Technical Conference and Exhibition, Dallas, TX, October 1-4.

Louviere, R.J., and J.A. Reddoch, 1993, “Onsite Disposal of Rig-Generated Waste via Slurrification and Annular Injection,” SPE/IADC 25755, presented at SPE/IADC Drilling Conference, Amsterdam, Netherlands, February 28-March 2.

Lowe, D.J., 1993, "NORM Cleaning and Disposal Using Closed-Loop Hydroblasting or Solvent Bath and Underground Injection System," SPE 25935, presented at SPE/EPA Exploration \& Production Environmental Conference, San Antonio, TX, March 7-10.

Malachosky, E., B.E. Shannon, and J.E. Jackson, 1991, “Offshore Disposal of Oil-Based Drilling Fluid Waste: An Environmentally Acceptable Solution," SPE 23372, presented at the First International Conference on Health, Safety and Environment, The Hague, Netherlands, November 10-14.

Marinello, S.A., F.L. Lyon, and W.T. Ballantine, 2001, "Disposal of E\&P Waste by Injection: An Assessment of Technology and Regulatory Impacts," SPE 66521, presented at the SPE/EPA/DOE Exploration \& Production Environmental Conference, San Antonio, TX, February 26-28.

MI/SWACO, 2002, data on 22 slurry injection trials, provided by S. Simmons, MI/SWACO, Houston, TX, to J. Veil, Argonne National Laboratory, Washington, DC, October. 
Minton, R.C., 1996, “A Novel Retrofit Solution for Oily Cuttings Slurrying,” SPE 35951, presented at the SPE International Conference on Health, Safety and Environment in Oil and Gas Exploration and Production, New Orleans, LA, June 9-12.

Minton, R.C., and B. Secoy, 1992, “Annular Re-injection of Drilling Wastes,” SPE 25042, presented at the European Petroleum Conference, Cannes, France, November 16-18.

Minton, R.C., A. Meader, and S.M. Willson, 1992, "Downhole Cuttings Injection Allows Use of Oil-Based Muds," World Oil, pp. 47-52, October.

Moschovidis, Z.A., D.C. Gardner, G.V. Sund, and R.W. Veatch, Jr., 1993, "Disposal of Oily Cuttings by Downhole Periodic Fracturing Injections in Valhall-North Sea: A Case Study and Modelling Concepts," SPE/IADC 25757, presented at SPE/IADC Drilling Conference, Amsterdam, Netherlands, February 23-25.

Moschovidis, Z., R. Steiger, X. Weng, M. Frank1, A. Abou-Sayed, C. Fleming, S. Wolhart, B. McDaniel, A. Sinor, S. Ottesen, T. Herbert, C. Wright, N. Warpinski, R. Beecher, J. Dudley, D. Zinno, and O. Akhmedov, 1999, "The Mounds Drill Cuttings Injection Field Experiment," presented at the $37^{\text {th }}$ U.S. Rock Mechanics Symposium, Vail, CO, June 6-9.

Moschovidis, Z., R. Steiger, R. Peterson, N. Warpinski, C. Wright, E. Chesney, J. Hagan, A. Abou-Sayed, R. Keck, M. Frankl, C. Fleming, S. Wolhart, B. McDaniel, A. Sinor, S. Ottesen, L. Miller, R. Beecher, J. Dudley, D. Zinno, and O. Akhmedov, 2000, “The Mounds Drill-Cuttings Injection Field Experiment: Final Results and Conclusions," IADC/SPE 59115, presented at the IADC/SPE Drilling Conference, New Orleans, LA, February 23-25.

Nagel, N.B., and K.J. Strachan, 1998, "Implementation of Cuttings Reinjection at the Ecofisk Field," SPE/ISRM 47218, presented at the SPE/ISRM Eurock '98, Trondheim, Norway, July 810.

Omrcen, B., B. Loncaric, and V. Brkic, 2001, "Waste Disposal by Injection into Deep Wells," ETCE 2001-17093, Proceedings of the ETCE 2001 Engineering Technology Conference on Energy, Houston, TX, February 5-7.

Paige, R.W., J.D.M Roberts, L.R. Murray, and D.W. Mellor, 1992, "Fracture Measurement Using Hydraulic Impedance Testing," SPE 24824, presented at SPE Annual Technical Conference and Exhibition, Washington, DC, October 4-7.

Paige, R.W., L.R. Murray, and J.D.M. Roberts, 1993, "Field Application of Hydraulic Impedance Testing for Fracture Measurement," SPE 26525, presented at the SPE Annual Technical Conference and Exhibition, Houston, TX, October 3-6.

Pekich, L.L., 2002, letter on injection technology for disposing of solid exploration and production wastes from Pekich, Phillips Alaska, Inc., Anchorage, AK, to J. Veil, Argonne National Laboratory, Washington, DC, September 10. 
Puder, M.G., B. Bryson, and J.A. Veil, 2002, "Compendium of Regulatory Requirements Governing Underground Injection of Drilling Wastes," draft prepared by Argonne National Laboratory for the U.S. Department of Energy, Office of Fossil Energy, National Petroleum Technology Office, November.

Reddoch, J., C. Taylor, and R. Smith, 1995, "Successful Drill Cuttings Reinjection (CRI) Case History on a Subsea Template Utilizing Low Cost Natural Oil Based Mud," SPE 30433, presented at Offshore Europe Conference, Aberdeen Scotland, September 5-8.

Reddoch, J., C. Taylor, and R. Smith, 1996, "Successful Drill Cuttings Reinjection (CRI) Case History with Multiple Producing Wells on a Subsea Template Utilizing Low Cost Natural Oil Based Mud," SPE 35328, presented at International Petroleum Conference and Exhibition, Villahermosa, Mexico, March 5-7.

Reed, A.C., J.L. Mathews, M.S. Bruno, and S.E. Olmstead, 2001, “Chevron Safely Disposes One Million Barrels of NORM in Louisiana through Slurry Fracture Injection," SPE 71434, presented at 2001 SPE Annual Technical Conference and Exhibition, New Orleans, LA, September 30 October 3.

Regg, J.B., and T.E. Maunder, 2003, letter and electronic mail containing comments on February 6, 2003, draft version of this report from Regg and Maunder, Alaska Oil and Gas Conservation Commission, Anchorage, AK, to J. Veil, Argonne National Laboratory, Washington, DC, April 2 and 18.

Saasen, A., A. Bale, R. Corneliussen, and P.B. Kristiansen, 1998, "The First Cuttings Injection Operation Worldwide in a Subsea Annulus: Equipment and Operational Experience," SPE 48985, presented at the 1998 SPE Annual Technical Conference and Exhibition, New Orleans, LA, September 27-30.

Saasen, A., J.E. Paulsen, and K. Holthe, 2000, "Environmental Priorities of Re-Injection and Land Based Handling of Drilled Cuttings and Affiliated Fluids," SPE 61262, presented at the SPE International Conference on Health, Safety and the Environment in Oil and Gas Exploration and Production, Stavanger, Norway.

Saasen, A., T.N. Tran, H. Joranson, E. Meyer, G. Gabrielsen, and A.E. Tronstad, 2001, "Subsea Re-Injection of Drilled Cuttings - Operational Experience," SPE/IADC 67733, presented at the SPE/IADC Drilling Conference, Amsterdam, Netherlands, February 27-March 1.

Satterlee, K.S., III, 2003, electronic mail message containing comments on February 6, 2003, draft version of this report from Satterlee, Shell Exploration and Production Company, New Orleans, LA, to J. Veil, Argonne National Laboratory, Washington, DC, March 18. 
Schuh, P.R., B.W. Secoy, and E. Sorrie, 1993, "Case History: Cuttings Reinjection on the Murdoch Development Project in the Southern Sector of the North Sea," SPE 26680, presented at the Offshore European Conference, Aberdeen, Scotland, September 7-10.

Schmidt, J.H., W.L. Friar, M.L. Bill, and G.D. Cooper, 1999, "Large-Scale Injection of North Slope Drilling Cuttings," SPE 52738, presented at the 1999 SPE/EPA Exploration and Production Environmental Conference, Austin, TX, February 28-March 3.

Sipple-Srinivasan, M.M., M.S. Bruno, R.A. Bilak, and P.G. Danyluk, 1997, "Field Experiences with Oilfield Waste Disposal through Slurry Fracture Injection," SPE 38254, presented at the SPE Western Regional Meeting, Long Beach, CA, June 23-27.

Sipple-Srinivasan, M.M., M.S. Bruno, K.A. Hejl, P.G. Danyluk, and S.E. Olmstead, 1998, "Disposal of Crude Contaminated Soil through Slurry Fracture Injection at the West Coyote Field in California," SPE 46239, presented at the SPE Western Regional Meeting, Bakersfield, CA, May 10-13.

Sirevåg, G., and A. Bale, 1993, "An Improved Method for Grinding and Reinjecting of Drill Cuttings," SPE/IADC 25758, presented at SPE/IADC Drilling Conference, Amsterdam, Netherlands, February 23-25.

Susich, M. L., 2002, email message with attached file describing Marathon's slurry injection project, from Susich, Marathon Oil - Alaska Business Unit, Anchorage, AK, to J.A. Veil, Argonne National Laboratory, Washington, DC, November 6.

Syed, T., and T. Cutler, 2001, "Review of Class I Injection Wells - North Slope of Alaska," presented at Ground Water Protection Council Annual Forum, Reno, NV, September 22-26.

Terralog, 2001, information on Terralog slurry injection projects, provided by M.S. Bruno, Terralog Technologies, Inc., Arcadia, CA, to J.A. Veil, Argonne National Laboratory, Washington, DC, December 3.

Terralog, 2002a, "Development of Improved Oil Field Waste Injection Disposal Techniques," prepared by Terralog Technologies USA, Inc., Arcadia, CA, for U.S. Department of Energy, National Petroleum Technology Office, March 31.

Terralog, 2002b, Access database of slurry fracture injection data collected by Terralog Technologies Inc., Arcadia, CA, database accompanies Terralog (2002a) and was submitted to U.S. Department of Energy, National Petroleum Technology Office.

Tomasko, D., D. Elcock, J. Veil, and D. Caudle, 1997, "Risk Analyses for Disposing Nonhazardous Oil Field Wastes in Salt Caverns," prepared by Argonne National Laboratory for DOE Office of Fossil Energy, December. 
Van Gils, J.M.I, T.J.O Thornton, M. Kece, W. Bennet, and G.K. Yule, 1995, "Cuttings Reinjection on Mature Platforms: a Case History," SPE 29377, presented at SPE/IADC Drilling Conference, Amsterdam, Netherlands, February 28-March 2.

Veil, J.A., 1997, “Costs for Offsite Disposal of Nonhazardous Oil Field Wastes: Salt Caverns versus Other Disposal Methods," prepared by Argonne National Laboratory for DOE Office of Fossil Energy (April 1997); also published by DOE - National Petroleum Technology Office as DOE/BC/W-31-109-ENG-38-3, DE97008692, September.

Veil, J., D. Elcock, M. Raivel, D. Caudle, R. Ayers, and B. Grunewald, 1996, "Preliminary Technical and Legal Evaluation of Disposing of Nonhazardous Oil Field Waste into Salt Caverns," prepared by Argonne National Laboratory for DOE Office of Fossil Energy, June.

Veil, J.A., K.P. Smith, D. Tomasko, D. Elcock, D.L. Blunt, and G.P. Williams, 1998, "Disposal of NORM-Contaminated Oil Field Waste in Salt Caverns," prepared by Argonne National Laboratory for DOE National Petroleum Technology Office, August.

Veil, J.A., 2002, “Drilling Waste Management," Journal of Petroleum Technology, pp. 50-52 November.

Wakim, P.G., 1987, “API 1985 Production Waste Survey, Statistical Analysis and Survey Results," American Petroleum Institute, Washington, DC, October.

Warpinski, N.R., and B.P. Engler, 2001, “Assessment of Downhole-Tiltmeter Fracture Monitoring at the Mounds Drill Cuttings Test," SAND2001-1054, prepared by Sandia National Laboratories for the U.S. Department of Energy, April.

Warpinski, N.R., P.T. Branagan, S.L. Wolhart, Z.A. Moschovidis, and K.D. Mahrer, 1999, "Microseismic Monitoring of the Mounds Drill Cuttings Injection Tests," presented at the $37^{\text {th }}$ U.S. Rock Mechanics Symposium, Vail, CO, June 6-9.

Wascom, C.D., 2002, “Annular Disposal of Exploration and Production Wastes," presented at the Ground Water Protection Council Annual Forum, San Francisco, CA, September 22-25.

Willson, S.M., M. Rylance, and N.C. Last, 1993, "Fracture Mechanics Issues Relating to Cuttings Re-Injection at Shallow Depth," SPE/IADC 25756, presented at SPE/IADC Drilling Conference, Amsterdam, Netherlands, February 28-March 2.

Wittenbach, S.A., 2002, table including information on North Sea cuttings reinjection (data compiled by D. Smith, MGA Consultancy Service, Aberdeen, Scotland, UK), provided by Wittenbach, Kerr-McGee Oil and Gas Corporation, Houston, TX, to J. Veil, Argonne National Laboratory, Washington, DC, December 4. 
Wood, G.L., G. Hulbert, and D. Cocking, 1995, "Drill Cuttings Disposal into a Producing Sandstone Formation," SPE 30432, presented at the Offshore Europe Conference, Aberdeen, Scotland, September 5-8.

Wright, C.A., E.J. Davis, G. Wang, and L. Weijers, 1999, "Downhole Tiltmeter Fracture Mapping: A New Tool for Direct Measurement of Hydraulic Fracture Growth," presented at the $37^{\text {th }}$ U.S. Rock Mechanics Symposium, Vail, CO, June 6-9.

Yod-In-Lom, W., and B.A. Doyle, 2002, "Deep Well Injection of Mercury Contaminated Sludge in the Gulf of Thailand," SPE 73964, presented at the SPE International Conference on Health, Safety and Environment in Oil and Gas Exploration and Production, Kuala Lumpur, Malaysia, March 20-22. 


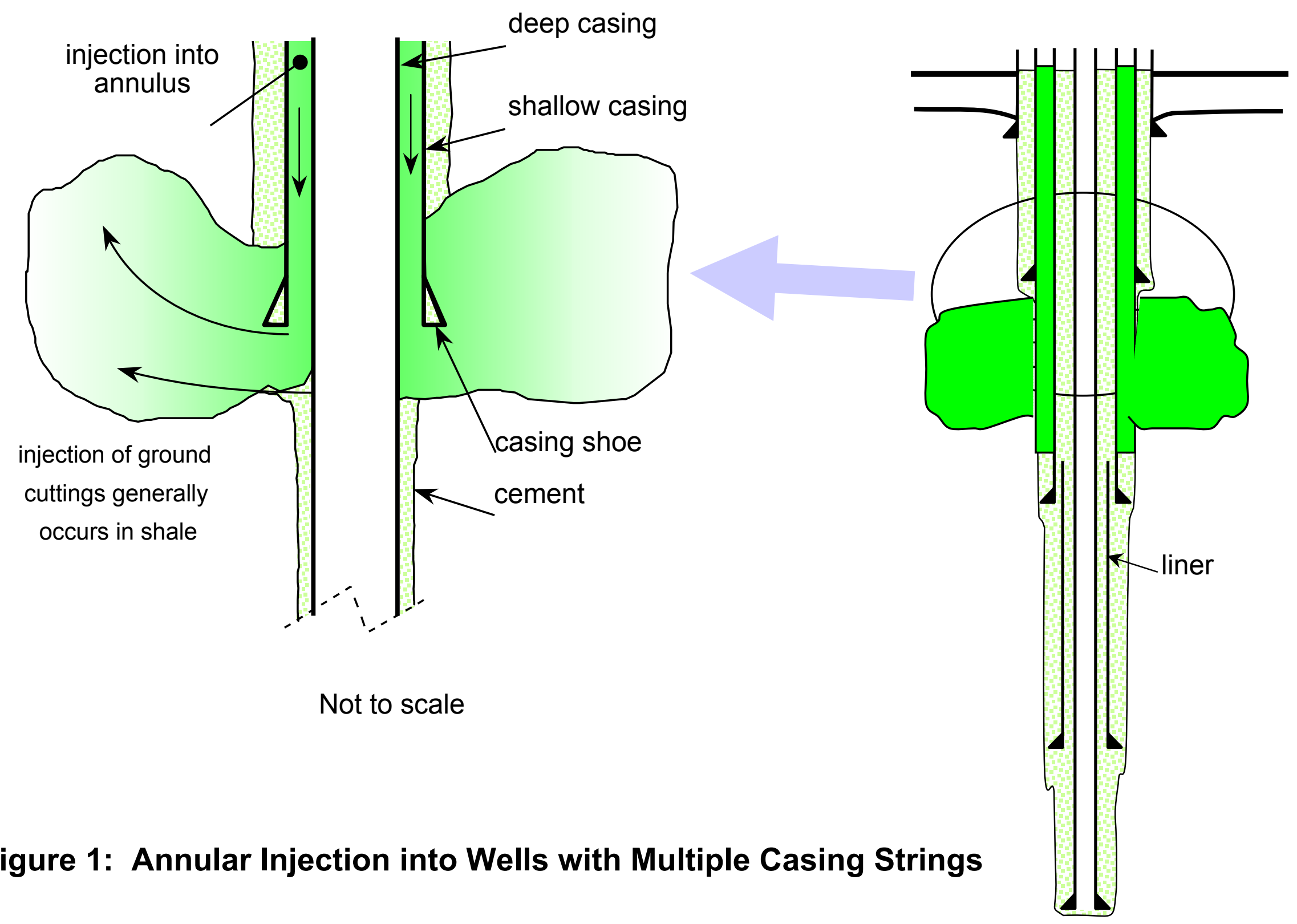




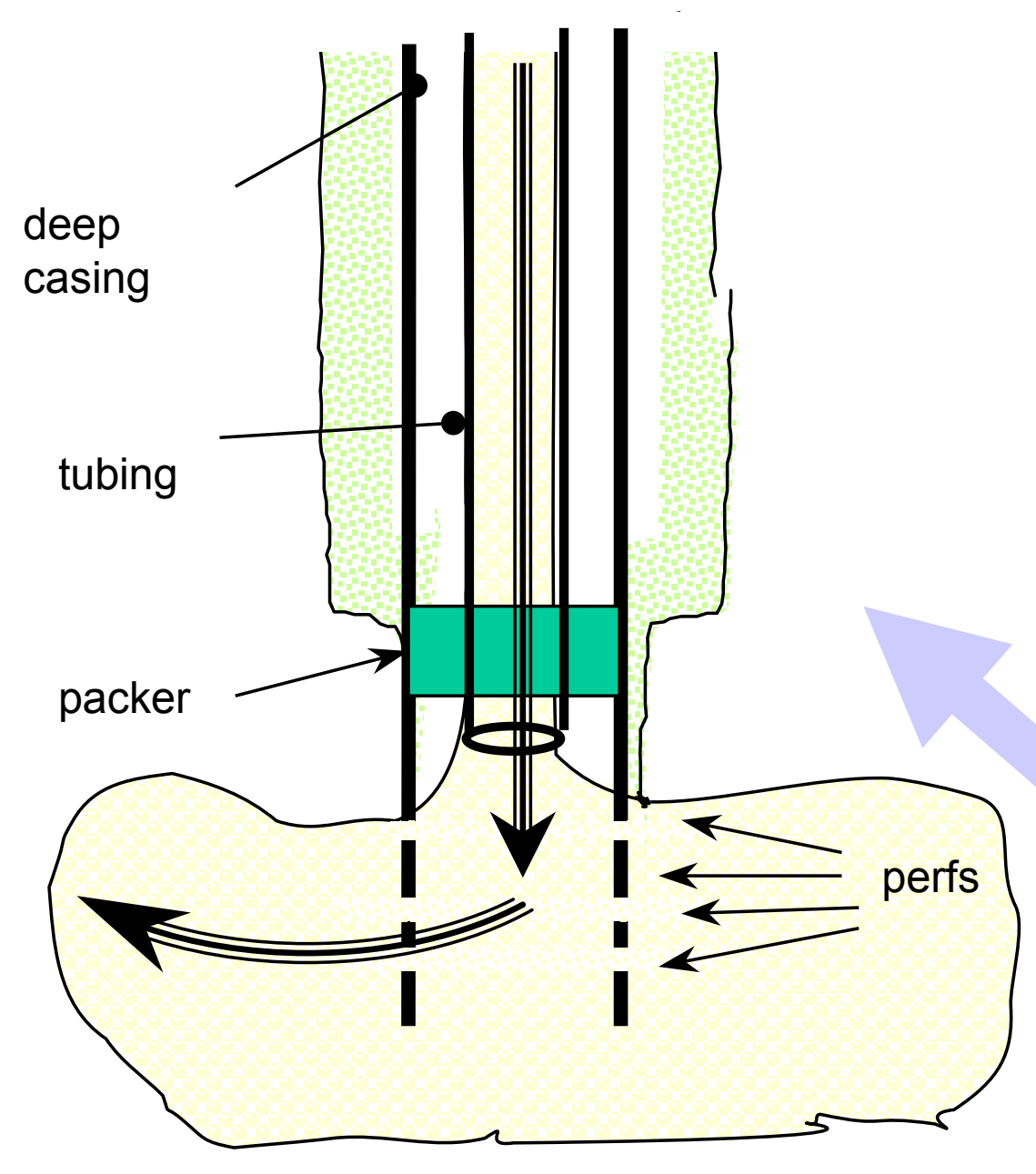

Not to scale

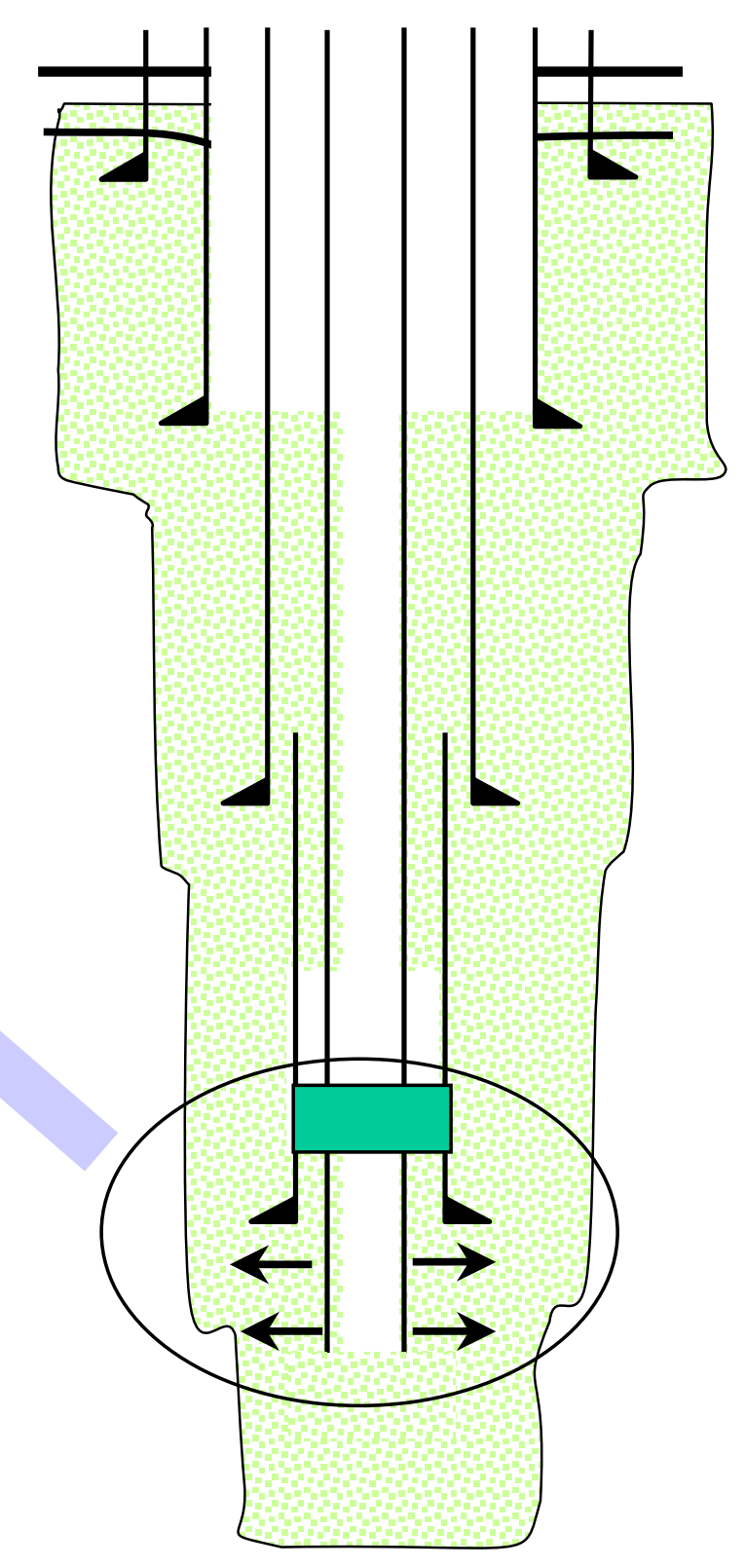

Figure 2: Injection into Dedicated injection Well 


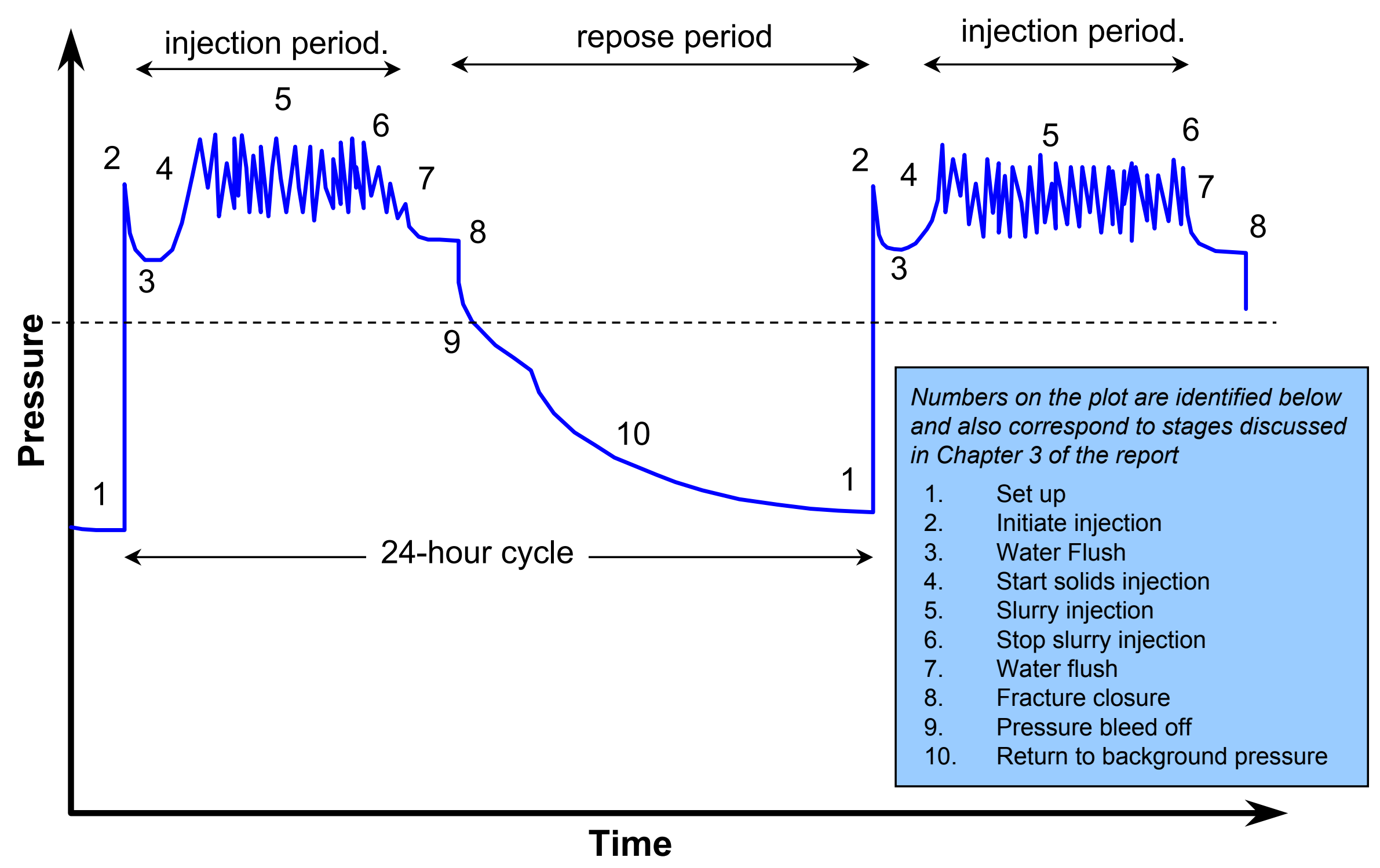

Figure 3: Pressure vs. Time Plot for Two Daily Cycles of Slurry Injection 


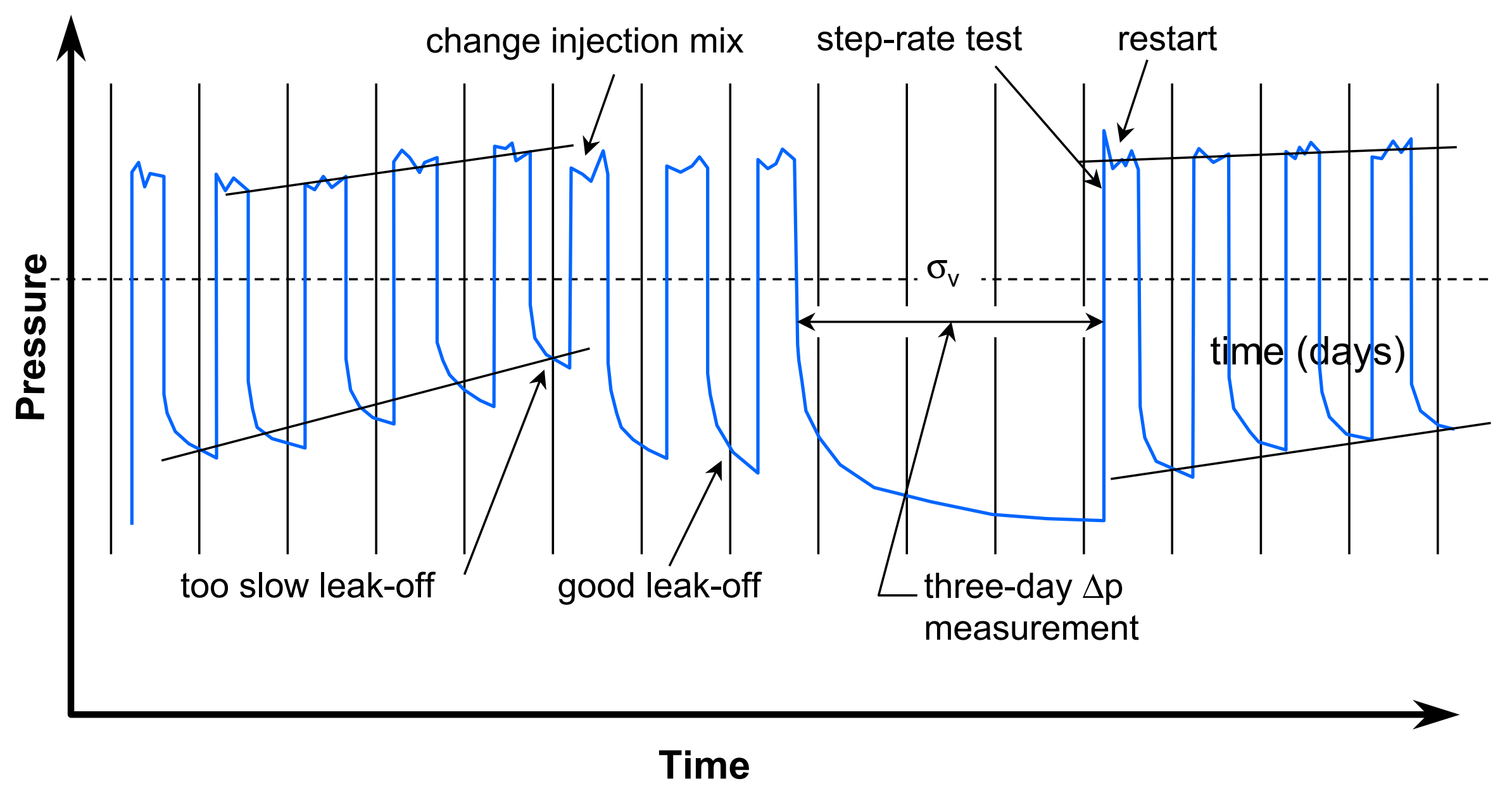

Figure 4: Long-Term Solids Injection Approach 


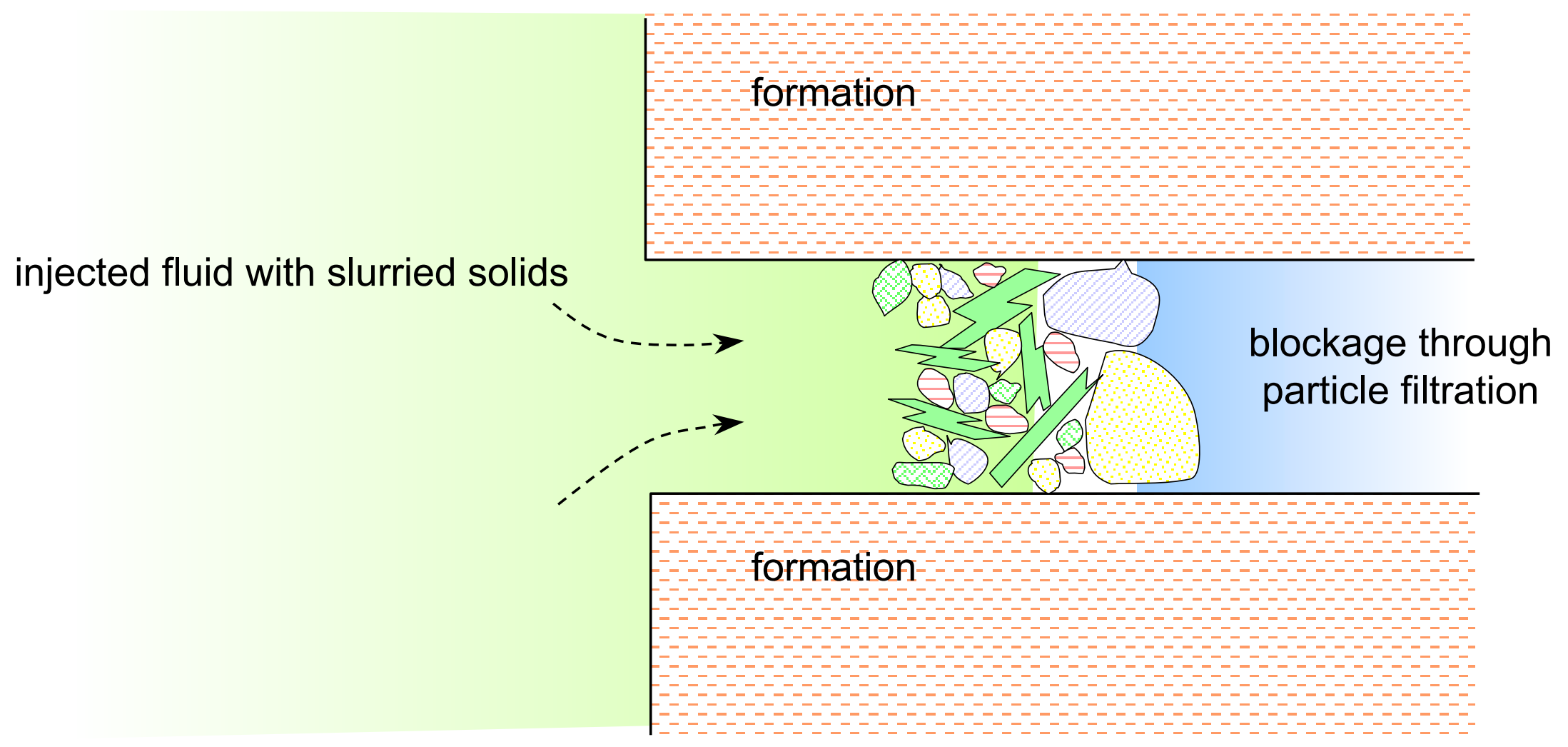

Figure 5: Screening Out of Injected Particles at Fracture Tip 


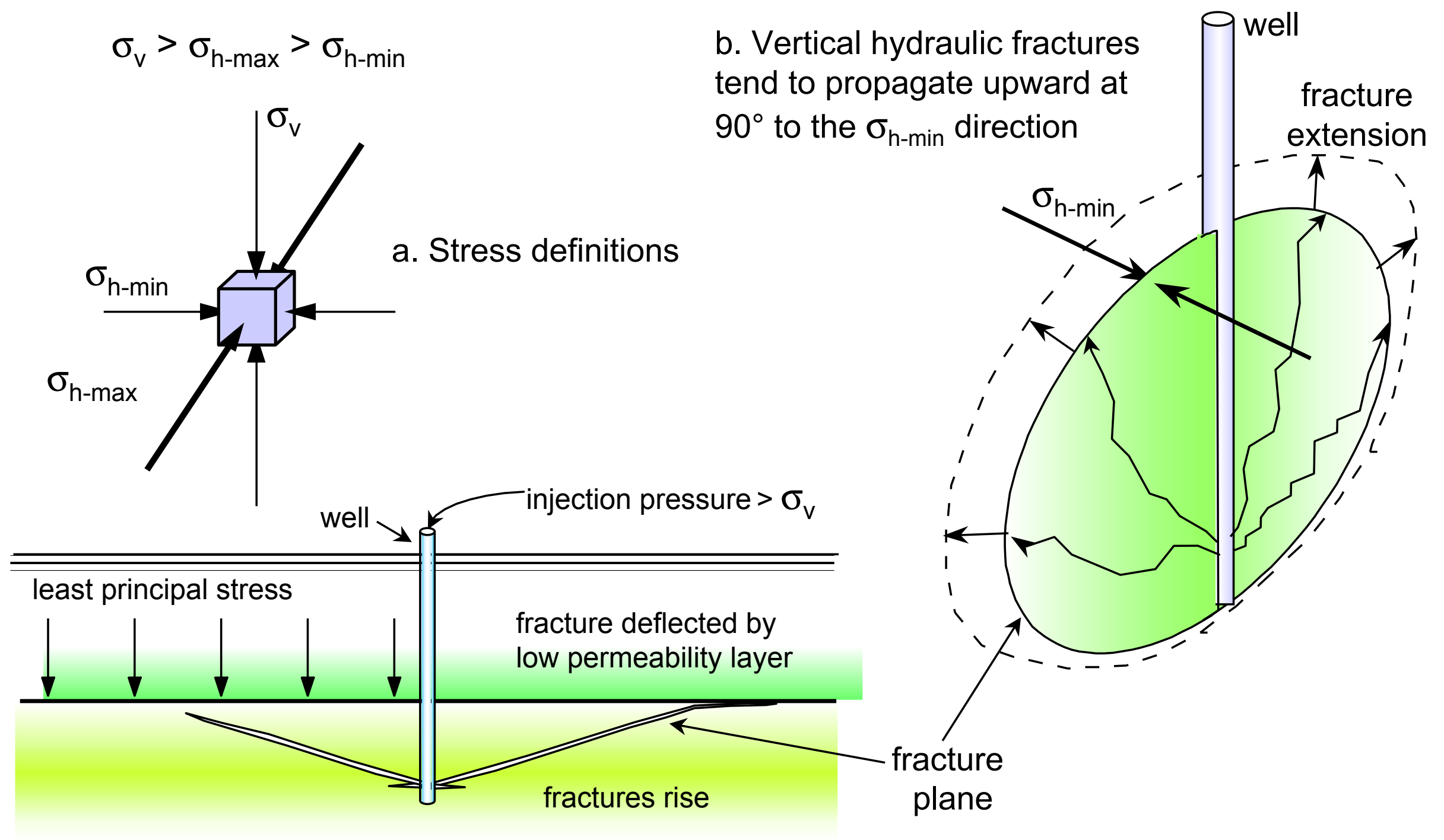

c. If $\sigma_{v}$ is the least stress, fractures will tend to be close to horizontal, rising at a gentle angle 


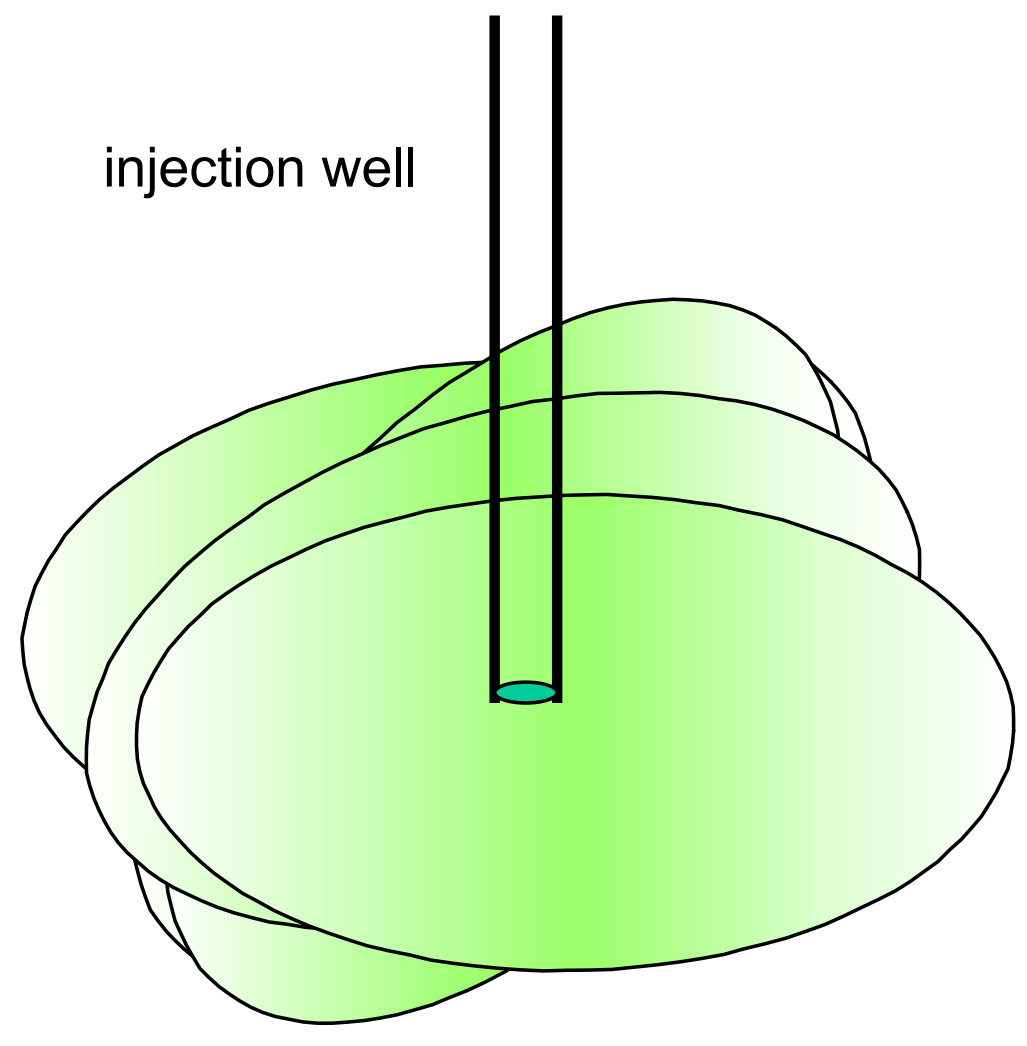

side view

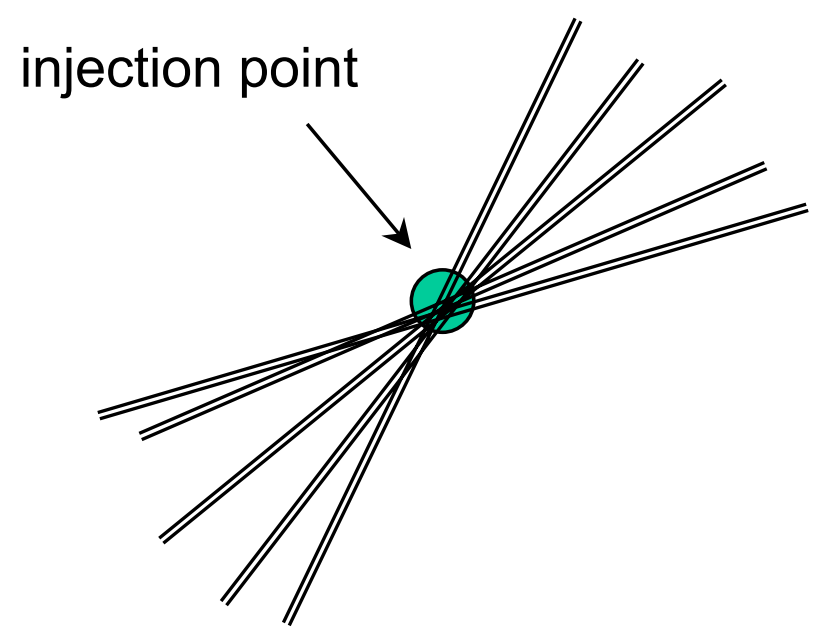

plan view

Figure 7: Series of Vertical Planar Fractures with Different Azimuths Depicting the Disposal Domain Concept (based on Moschovidis et al. 1993) 


\begin{tabular}{|c|c|c|c|c|c|c|c|c|c|c|c|c|}
\hline Site Location/Name & $\begin{array}{l}\text { Operator } \\
\text { Generating } \\
\text { Wastes } \\
\end{array}$ & Source of Information & $\begin{array}{l}\text { Service } \\
\text { Company } \\
\text { Doing } \\
\text { Injection } \\
\end{array}$ & $\begin{array}{l}\text { Geology of Injection } \\
\text { Zone (type of rock, } \\
\text { porosity, permeability) }\end{array}$ & $\begin{array}{l}\text { Depth of } \\
\text { Injection Zone }\end{array}$ & \begin{tabular}{|l} 
Depth of \\
Perforations/ \\
annular \\
Injection
\end{tabular} & $\begin{array}{l}\text { Geology and } \\
\text { Depth of } \\
\text { Confining } \\
\text { Layer } \\
\end{array}$ & $\begin{array}{l}\text { Other } \\
\text { Geological } \\
\text { Information }\end{array}$ & $\begin{array}{l}\text { Dates and Duration } \\
\text { of Injection }\end{array}$ & Injection Rate & $\begin{array}{l}\text { Injection } \\
\text { Pressure }\end{array}$ & $\begin{array}{l}\text { Type of } \\
\text { Injection }\end{array}$ \\
\hline $\begin{array}{l}\text { Alaska/Cook Inlet } \\
\text { onshore/lvan River }\end{array}$ & Unocal & MI/SWACO (2002) & MI/SWACO & & $9,700^{\prime}$ & & & & & $3.0 \mathrm{bbl} / \mathrm{min}$ & $1,875 \mathrm{psi}$ & $\begin{array}{l}\text { dedicated } \\
\text { well, tubing } \\
\text { and packer }\end{array}$ \\
\hline $\begin{array}{l}\text { Alaska/Cook Inlet/King } \\
\text { Salmon }\end{array}$ & Unocal & MI/SWACO (2002) & MI/SWACO & & & & & & $3 / 01-8 / 01$ & & & annular \\
\hline Alaska/Cook Inlet/Osprey & Forest & MI/SWACO (2002) & MI/SWACO & & & & & & $8 / 01-9 / 02$ & $2-4 \mathrm{bbl} / \mathrm{min}$ & & $\begin{array}{l}\text { dedicated } \\
\text { well, tubing } \\
\text { and packer }\end{array}$ \\
\hline Alaska/Cook Inlet/NCIU B-1 & Phillips & $\begin{array}{l}\text { Apollo Services (2002); } \\
\text { Regg \& Maunder (2003) }\end{array}$ & $\begin{array}{l}\text { Apollo } \\
\text { Services }\end{array}$ & & & $11,761^{\prime}$ & & & 7/15/97 - 1/19/99 & $1.0-2.0 \mathrm{bbl} / \mathrm{min}$ & $\begin{array}{l}1,000-2,000 \\
\text { psi }\end{array}$ & annular \\
\hline $\begin{array}{l}\text { Alaska/Kenai/Anchor } \\
\text { Point//Hansen\#1 }\end{array}$ & Phillips & $\begin{array}{l}\text { MI/SWACO (2002); Regg \& } \\
\text { Maunder (2003) }\end{array}$ & MI/SWACO & & $5,500^{\prime}$ & & & & & $2.5 \mathrm{bbl} / \mathrm{min}$ & $1,150 \mathrm{psi}$ & annular \\
\hline $\begin{array}{l}\text { Alaska/Kenai/mobile grind } \\
\text { and inject (G\&I) plant (3 } \\
\text { wells) }\end{array}$ & Marathon & Susich (2002) & & $\begin{array}{l}\text { Sterling sandstone, which } \\
\text { becomes discontinuous } \\
\text { laterally into nonpermeable } \\
\text { shales with top and bottom } \\
\text { seals made up of } \\
\text { embedded shale lenses; } \\
\text { porosity: } 25 \text { - } 30 \% \text {; } \\
\text { thicknesses averaging 20- } \\
40 \text { '; permeability: } 300 \text { - } \\
1,000 \text { md. }\end{array}$ & $4,410^{\prime}-5,152^{\prime}$ & $\begin{array}{l}\text { A-10 (4,410' - } \\
\left.4,490^{\prime}\right) ; A-11 \\
\left(4,525^{\prime}-4,560^{\prime}\right) ; \\
\text { C1 }\left(5,106^{\prime}-\right. \\
\left.5,152^{\prime}\right)\end{array}$ & & $\begin{array}{l}\text { | } \\
\\
\text { G\&I plant is } \\
\text { located in } \\
\text { wetlands and } \\
\text { day-to-day } \\
\text { operations are } \\
\text { conducted on } \\
\text { gravel roads and } \\
\text { pads } \\
\end{array}$ & $\begin{array}{l}\text { Injection operations } \\
\text { began in } 1995 . \\
\text { Injection can occur } \\
\text { anytime of the year } \\
\text { and coincides with } \\
\text { drilling operations. } \\
\text { Daylight "batch" jobs } \\
\text { are performed and } \\
\text { can last up 10-12 } \\
\text { hours. An injection } \\
\text { period is comprised } \\
\text { of several days of } \\
\text { activity and its } \\
\text { duration is directly } \\
\text { tied to the amount of } \\
\text { material stored } \\
\text { onsite, as well as } \\
\text { supporting drilling } \\
\text { and production } \\
\text { operations. Typical } \\
\text { injection periods run } \\
2-5 \text { days a week and } \\
\text { each drilled well may } \\
\text { require 3-5 injection } \\
\text { periods }\end{array}$ & $\begin{array}{l}3-6 \mathrm{bbl} / \mathrm{min} ; \\
\text { average } \sim 5 \\
\text { bbl/min }\end{array}$ & $\begin{array}{l}2,132- \\
2,252 \mathrm{psi}\end{array}$ & $\begin{array}{l}\text { tubing and } \\
\text { packer }\end{array}$ \\
\hline $\begin{array}{l}\text { Alaska/Kenai/Ninilchik/NNA } \\
\# 1\end{array}$ & Unocal & $\begin{array}{l}\text { MI/SWACO (2002); Regg \& } \\
\text { Maunder \& Maunder (2003) }\end{array}$ & MI/SWACO & & $3,300^{\prime}$ & & & & & $3.3 \mathrm{bbl} / \mathrm{min}$ & $285 \mathrm{psi}$ & annular \\
\hline $\begin{array}{l}\text { Alaska/North } \\
\text { Slope/Alpine/CD1-01 }\end{array}$ & Phillips Alaska & $\begin{array}{l}\text { Regg \& Maunder \& Maunder } \\
(2003)\end{array}$ & & & & & & & & & & annular \\
\hline \begin{tabular}{|l|} 
Alaska/North \\
Slope/Alpine/CD1-03
\end{tabular} & Phillips Alaska & $\begin{array}{l}\text { Regg \& Maunder \& Maunder } \\
\text { (2003) }\end{array}$ & & & & & & & $8 / 00-9 / 00$ & & & annular \\
\hline
\end{tabular}




\begin{tabular}{|c|c|c|c|c|c|c|c|}
\hline Site Location/Name & Type of Waste Injected & $\begin{array}{l}\text { Volume of } \\
\text { Material } \\
\text { Injected } \\
\end{array}$ & $\begin{array}{l}\text { Slurry } \\
\text { Properties } \\
\text { (fluid, } \\
\text { density) } \\
\end{array}$ & $\begin{array}{l}\text { Pre-Injection } \\
\text { Processing/ } \\
\text { Treatment }\end{array}$ & Problems Experienced & Costs & Other Comments \\
\hline \begin{tabular}{|l} 
Alaska/Cook Inlet \\
onshore/lvan River
\end{tabular} & $\begin{array}{l}\text { water-based cuttings (very } \\
\text { large particle size) }\end{array}$ & 20,000 bbl slurry & $9.5-10.5 \mathrm{lb} / \mathrm{gal}$ & $\begin{array}{l}\text { gel/extender and } \\
\text { defoamer }\end{array}$ & $\begin{array}{l}\text { injection period restricted to } \\
\text { 30-day window; large } \\
\text { particle size impeded } \\
\text { injection }\end{array}$ & & \\
\hline \multicolumn{8}{|l|}{$\begin{array}{l}\text { Alaska/Cook Inlet/King } \\
\text { Salmon }\end{array}$} \\
\hline Alaska/Cook Inlet/Osprey & oil-based cuttings & $22,633 \mathrm{bbl}$ & & & & & $\begin{array}{l}\text { same as } \\
\text { Alaska/North } \\
\text { Slope/Alpine }\end{array}$ \\
\hline Alaska/Cook Inlet/NCIU B-1 & cuttings & $\begin{array}{l}221,400 \text { bbl } \\
\text { slurry (Apollo); } \\
134,325 \text { bbl } \\
\text { (Regg \& } \\
\text { Maunder) }\end{array}$ & $8.8-14.5 \mathrm{lb} / \mathrm{gal}$ & & & & $\begin{array}{l}\text { limited data provided } \\
\text { for this job }\end{array}$ \\
\hline $\begin{array}{l}\text { Alaska/Kenai/Anchor } \\
\text { Point/Hansen \#1 }\end{array}$ & $\begin{array}{l}\text { oil-based and water- } \\
\text { based cuttings; rain water }\end{array}$ & $67,224 \mathrm{bbl}$ & $9.8-11.0 \mathrm{lb} / \mathrm{gal}$ & $\begin{array}{l}\text { gel/extender and } \\
\text { defoamer }\end{array}$ & $\begin{array}{l}\text { dredge could not keep up } \\
\text { with real-time drilling rate; } \\
\text { cuttings placed in pit to be } \\
\text { removed later by dredge }\end{array}$ & & $\begin{array}{l}\text { hope to return to real } \\
\text { time injection by } \\
12 / 02 \text {; approval } \\
\text { given to dispose up } \\
\text { to } 140,000 \mathrm{bbl} \\
\end{array}$ \\
\hline $\begin{array}{l}\text { Alaska/Kenai/mobile grind } \\
\text { and inject (G\&I) plant (3 } \\
\text { wells) }\end{array}$ & $\begin{array}{l}\text { from 1995-1997, injected } \\
\text { E\&P exempt drilling } \\
\text { reserve pit muds, oil and } \\
\text { water based muds and } \\
\text { cuttings, NORM scale \& } \\
\text { sludges, NORM } \\
\text { contaminated gravels } \\
\text { (pipe yard), frac sands, } \\
\text { tank bottoms, } \\
\text { contaminated gravels } \\
\text { (E\&P Spills) and produced } \\
\text { water. From } 1998 \text { to the } \\
\text { present, inject water } \\
\text { based mud and cuttings } \\
\text { with periodic "Grind \& } \\
\text { Inject" activities to process } \\
\text { frac sands, tank bottoms } \\
\text { and contaminated gravels } \\
\text { (E\&P Spills). The G\&I } \\
\text { plant supplements } \\
\text { produced water disposal } \\
\text { requirements for } \\
\text { production operations on } \\
\text { an as-needed basis. }\end{array}$ & $\begin{array}{l}\text { daily volume } \\
3,000-3,500 \\
\text { bbl/day; to date, } \\
\text { have injected } 1.2 \\
\text { millions bbl } \\
\text { slurry comprised } \\
\text { of } 335,000 \text { bbl of } \\
\text { solid waste } \\
\text { material. }\end{array}$ & $\begin{array}{l}\text { slurry is made } \\
\text { up of water, } \\
\text { gel and caustic } \\
\text { soda; density: } \\
\text { mud weight } \\
\text { ranges in the } \\
9.0-9.5 \mathrm{lb} / \mathrm{gal} ; \\
\text { solids loading: } \\
10-20 \% \text { by } \\
\text { volume }\end{array}$ & $\begin{array}{l}\text { standard operating } \\
\text { procedure is to } \\
\text { preload the well } \\
\text { with } 3 \text { tubing } \\
\text { volumes ( } 175 \mathrm{bbl} \text { ) } \\
\text { of water and then } \\
\text { continuously pump } \\
\text { the slurry over a } \\
\text { series of shale } \\
\text { shakers. The fines } \\
\text { are injected at } 5 \\
\text { bbl/min for } 10-12 \\
\text { hours. The } \\
\text { oversize water } \\
\text { based drill mud } \\
\text { cuttings are } \\
\text { screened off and } \\
\text { stockpiled. At the } \\
\text { end of each day, } \\
\text { the well is flushed } \\
\text { with } 3 \text { tubing } \\
\text { volumes (175 bbl) } \\
\text {; of water. Grinding, } \\
\text { when required, is } \\
\text { performed by a } \\
\text { rotating ball mill. }\end{array}$ & & $\begin{array}{l}\text { Marathon has } \\
\text { reduced its } \\
\text { injection costs by } \\
73 \% \text { from } \\
\$ 53.62 / b b l \text { in } \\
1995 \text { to } \\
\$ 14.73 / \mathrm{bbl} \text { in } \\
2002 \text {. Since the } \\
\text { inception of the } \\
\text { injection } \\
\text { program, } \\
\text { disposal costs } \\
\text { have totaled } \$ 9.0 \\
\text { million. The } \\
\text { disposal costs } \\
\text { may range from } \\
\$ 3.00 / \text { bbl to } \\
\$ 20.00 / b b l \text { during } \\
\text { the year. This } \\
\text { range is the } \\
\text { result of higher } \\
\text { costs associated } \\
\text { with winter } \\
\text { operations } \\
\text { (heating, labor } \\
\text { and reduced } \\
\text { efficiency). }\end{array}$ & $\begin{array}{l} \\
\\
\\
\\
\text { third party laboratory } \\
\text { results confirm } \\
\text { whether or not the } \\
\text { oversized cuttings } \\
\text { are acceptable for } \\
\text { beneficial reuse. } \\
\text { The "clean" cuttings } \\
\text { are then used on } \\
\text { Marathon's road and } \\
\text { pad networks. } \\
\text { Marathon's Beneficial } \\
\text { Reuse program has } \\
\text { eliminated the need } \\
\text { to "process/treat" the } \\
\text { oversize drill well } \\
\text { cuttings (50 mesh - } \\
0.0117 \text { inches - 279 } \\
\text { microns.) } \\
\end{array}$ \\
\hline $\begin{array}{l}\text { Alaska/Kenai/Ninilchik/NNA } \\
\# 1\end{array}$ & $\begin{array}{l}\text { water-based cuttings and } \\
\text { other reserve pit contents }\end{array}$ & $\begin{array}{l}16,500 \mathrm{bbl} \text { water } \\
\text { and } 21,500 \mathrm{bbl} \\
\text { slurry }\end{array}$ & $9.3-10.5 \mathrm{lb} / \mathrm{gal}$ & $\begin{array}{l}\text { gel/extender and } \\
\text { defoamer }\end{array}$ & $\begin{array}{l}\text { Used SWACO Vacuum to } \\
\text { retrieve cuttings from } \\
\text { reserve pit }\end{array}$ & & $\begin{array}{l}\text { approval given to } \\
\text { dispose up to } \\
155,000 \mathrm{bbl} \\
\end{array}$ \\
\hline $\begin{array}{l}\text { Alaska/North } \\
\text { Slope/Alpine/CD1-01 }\end{array}$ & $\begin{array}{l}\text { mud, cuttings, reserve pit } \\
\text { fluids, cement- } \\
\text { contaminated mud, } \\
\text { completion fluids, } \\
\text { formation fluids, rig wash } \\
\text { water, and domestic waste }\end{array}$ & $5,221 \mathrm{bbl}$ & & & & & $\begin{array}{l}\text { well received } \\
\text { cuttings from } 1 \text { or } \\
\text { more other wells }\end{array}$ \\
\hline $\begin{array}{l}\text { Alaska/North } \\
\text { Slope/Alpine/CD1-03 }\end{array}$ & same as Alpine CD1-01 & $33,990 \mathrm{bbl}$ & & & & & $\begin{array}{l}\text { same as Alpine CD1- } \\
01\end{array}$ \\
\hline
\end{tabular}




\begin{tabular}{|c|c|c|c|c|c|c|c|c|c|c|c|c|}
\hline Site Location/Name & $\begin{array}{l}\text { Operator } \\
\text { Generating } \\
\text { Wastes } \\
\end{array}$ & Source of Information & $\begin{array}{l}\text { Service } \\
\text { Company } \\
\text { Doing } \\
\text { Injection } \\
\end{array}$ & $\begin{array}{l}\text { Geology of Injection } \\
\text { Zone (type of rock, } \\
\text { porosity, permeability) }\end{array}$ & $\begin{array}{l}\text { Depth of } \\
\text { Injection Zone }\end{array}$ & $\begin{array}{l}\text { Depth of } \\
\text { Perforations/ } \\
\text { annular } \\
\text { Injection }\end{array}$ & $\begin{array}{l}\text { Geology and } \\
\text { Depth of } \\
\text { Confining } \\
\text { Layer }\end{array}$ & $\begin{array}{l}\text { Other } \\
\text { Geological } \\
\text { Information }\end{array}$ & $\begin{array}{l}\text { Dates and Duration } \\
\text { of Injection }\end{array}$ & Injection Rate & $\begin{array}{l}\text { Injection } \\
\text { Pressure }\end{array}$ & $\begin{array}{l}\text { Type of } \\
\text { Injection }\end{array}$ \\
\hline \begin{tabular}{|l|} 
Alaska/North \\
Slope/Alpine/CD1-05
\end{tabular} & Phillips Alaska & $\begin{array}{l}\text { Regg \& Maunder \& Maunder } \\
(2003)\end{array}$ & & & & & & & $1 / 00$ & & & annular \\
\hline \begin{tabular}{|l|} 
Alaska/North \\
Slope/Alpine/CD1-13
\end{tabular} & Phillips Alaska & $\begin{array}{l}\text { Regg \& Maunder \& Maunder } \\
(2003)\end{array}$ & & & & & & & & & & annular \\
\hline $\begin{array}{l}\text { Alaska/North } \\
\text { Slope/Alpine/CD1-16 }\end{array}$ & Phillips Alaska & $\begin{array}{l}\text { Regg \& Maunder \& Maunder } \\
\text { (2003) }\end{array}$ & & & & & & & & & & annular \\
\hline \begin{tabular}{|l|} 
Alaska/North \\
Slope/Alpine/CD1-19 \\
\end{tabular} & Phillips Alaska & $\begin{array}{l}\text { Regg \& Maunder \& Maunder } \\
(2003)\end{array}$ & & & & & & & & & & annular \\
\hline $\begin{array}{l}\text { Alaska/North } \\
\text { Slope/Alpine/CD1-23 }\end{array}$ & Phillips Alaska & $\begin{array}{l}\text { Regg \& Maunder \& Maunder } \\
(2003)\end{array}$ & & & & & & & & & & annular \\
\hline $\begin{array}{l}\text { Alaska/North } \\
\text { Slope/Alpine/CD1-24 }\end{array}$ & Phillips Alaska & $\begin{array}{l}\text { Regg \& Maunder \& Maunder } \\
\text { (2003) }\end{array}$ & & & & & & & & & & annular \\
\hline \begin{tabular}{|l} 
Alaska/North \\
Slope/Alpine/CD1-25
\end{tabular} & Phillips Alaska & $\begin{array}{l}\text { Regg \& Maunder \& Maunder } \\
\text { (2003) }\end{array}$ & & & & & & & $6 / 00-8 / 00$ & & & annular \\
\hline $\begin{array}{l}\text { Alaska/North } \\
\text { Slope/Alpine/CD1-27 }\end{array}$ & Phillips Alaska & $\begin{array}{l}\text { Regg \& Maunder \& Maunder } \\
(2003)\end{array}$ & & & & & & & & & & annular \\
\hline $\begin{array}{l}\text { Alaska/North } \\
\text { Slope/Alpine/CD1-31 }\end{array}$ & Phillips Alaska & $\begin{array}{l}\text { Regg \& Maunder \& Maunder } \\
(2003)\end{array}$ & & & & & & & $2 / 01-3 / 01$ & & & annular \\
\hline \begin{tabular}{|l|} 
Alaska/North \\
Slope/Alpine/CD1-32
\end{tabular} & Phillips Alaska & $\begin{array}{l}\text { Regg \& Maunder \& Maunder } \\
\text { (2003) }\end{array}$ & & & & & & & & & & annular \\
\hline $\begin{array}{l}\text { Alaska/North } \\
\text { Slope/Alpine/CD1-34 }\end{array}$ & Phillips Alaska & $\begin{array}{l}\text { Regg \& Maunder \& Maunder } \\
\text { (2003) }\end{array}$ & & & & & & & $5 / 00$ & & & annular \\
\hline \begin{tabular}{|l|} 
Alaska/North \\
Slope/Alpine/CD1-35
\end{tabular} & Phillips Alaska & $\begin{array}{l}\text { Regg \& Maunder \& Maunder } \\
\text { (2003) }\end{array}$ & & & & & & & & & & annular \\
\hline \begin{tabular}{|l|} 
Alaska/North \\
Slope/Alpine/CD1-36
\end{tabular} & Phillips Alaska & $\begin{array}{l}\text { Regg \& Maunder \& Maunder } \\
\text { (2003) }\end{array}$ & & & & & & & & & & annular \\
\hline $\begin{array}{l}\text { Alaska/North } \\
\text { Slope/Alpine/CD1-37 }\end{array}$ & Phillips Alaska & $\begin{array}{l}\text { Regg \& Maunder \& Maunder } \\
\text { (2003) }\end{array}$ & & & & & & & & & & annular \\
\hline $\begin{array}{l}\text { Alaska/North } \\
\text { Slope/Alpine/CD1-38 }\end{array}$ & Phillips Alaska & $\begin{array}{l}\text { Regg \& Maunder \& Maunder } \\
(2003)\end{array}$ & & & & & & & $3 / 00-5 / 00$ & & & annular \\
\hline \begin{tabular}{|l|} 
Alaska/North \\
Slope/Alpine/CD1-39
\end{tabular} & Phillips Alaska & $\begin{array}{l}\text { Regg \& Maunder \& Maunder } \\
(2003)\end{array}$ & & & & & & & & & & annular \\
\hline $\begin{array}{l}\text { Alaska/North } \\
\text { Slope/Alpine/CD1-40 }\end{array}$ & Phillips Alaska & $\begin{array}{l}\text { Regg \& Maunder \& Maunder } \\
\text { (2003) }\end{array}$ & & & & & & & & & & annular \\
\hline \begin{tabular}{|l|} 
Alaska/North \\
Slope/Alpine/CD1-41
\end{tabular} & Phillips Alaska & $\begin{array}{l}\text { Regg \& Maunder \& Maunder } \\
(2003)\end{array}$ & & & & & & & $3 / 00$ & & & annular \\
\hline $\begin{array}{l}\text { Alaska/North } \\
\text { Slope/Alpine/CD1-42 }\end{array}$ & Phillips Alaska & $\begin{array}{l}\text { Regg \& Maunder \& Maunder } \\
\text { (2003) }\end{array}$ & & & & & & & & & & annular \\
\hline $\begin{array}{l}\text { Alaska/North } \\
\text { Slope/Alpine/CD1-43 }\end{array}$ & Phillips Alaska & $\begin{array}{l}\text { Regg \& Maunder \& Maunder } \\
\text { (2003) }\end{array}$ & & & & & & & $1 / 01-2 / 01$ & & & annular \\
\hline $\begin{array}{l}\text { Alaska/North } \\
\text { Slope/Alpine/CD1-44 }\end{array}$ & Phillips Alaska & $\begin{array}{l}\text { Regg \& Maunder \& Maunder } \\
(2003)\end{array}$ & & & & & & & $12 / 00-1 / 01$ & & & annular \\
\hline $\begin{array}{l}\text { Alaska/North } \\
\text { Slope/Alpine/CD1-45 }\end{array}$ & Phillips Alaska & $\begin{array}{l}\text { Regg \& Maunder \& Maunder } \\
\text { (2003) }\end{array}$ & & & & & & & & & & annular \\
\hline $\begin{array}{l}\text { Alaska/North } \\
\text { Slope/Alpine/CD2-14 }\end{array}$ & Phillips Alaska & $\begin{array}{l}\text { Regg \& Maunder \& Maunder } \\
\text { (2003) }\end{array}$ & & & & & & & & & & annular \\
\hline \begin{tabular}{|l|} 
Alaska/North \\
Slope/Alpine/CD2-15
\end{tabular} & Phillips Alaska & $\begin{array}{l}\text { Regg \& Maunder \& Maunder } \\
(2003)\end{array}$ & & & & & & & & & & annular \\
\hline \begin{tabular}{|l|} 
Alaska/North \\
Slope/Alpine/CD2-17
\end{tabular} & Phillips Alaska & $\begin{array}{l}\text { Regg \& Maunder \& Maunder } \\
\text { (2003) }\end{array}$ & & & & & & & & & & annular \\
\hline \begin{tabular}{|l|} 
Alaska/North \\
Slope/Alpine/CD2-24
\end{tabular} & Phillips Alaska & $\begin{array}{l}\text { Regg \& Maunder \& Maunder } \\
\text { (2003) }\end{array}$ & & & & & & & & & & annular \\
\hline $\begin{array}{l}\text { Alaska/North } \\
\text { Slope/Alpine/CD2-26 }\end{array}$ & Phillips Alaska & $\begin{array}{l}\text { Regg \& Maunder \& Maunder } \\
(2003)\end{array}$ & & & & & & & & & & annular \\
\hline $\begin{array}{l}\text { Alaska/North } \\
\text { Slope/Alpine/CD2-32 }\end{array}$ & Phillips Alaska & $\begin{array}{l}\text { Regg \& Maunder \& Maunder } \\
\text { (2003) }\end{array}$ & & & & & & & & & & annular \\
\hline \begin{tabular}{|l|} 
Alaska/North \\
Slope/Alpine/CD2-34
\end{tabular} & Phillips Alaska & $\begin{array}{l}\text { Regg \& Maunder \& Maunder } \\
\text { (2003) }\end{array}$ & & & & & & & & & & annular \\
\hline $\begin{array}{l}\text { Alaska/North } \\
\text { Slope/Alpine/CD2-39 }\end{array}$ & Phillips Alaska & $\begin{array}{l}\text { Regg \& Maunder \& Maunder } \\
\text { (2003) }\end{array}$ & & & & & & & & & & annular \\
\hline \begin{tabular}{|l|} 
Alaska/North \\
Slope/Alpine/CD2-42
\end{tabular} & Phillips Alaska & $\begin{array}{l}\text { Regg \& Maunder \& Maunder } \\
\text { (2003) }\end{array}$ & & & & & & & & & & annular \\
\hline
\end{tabular}




\begin{tabular}{|c|c|c|c|c|c|c|c|}
\hline Site Location/Name & Type of Waste Injected & $\begin{array}{l}\text { Volume of } \\
\text { Material } \\
\text { Injected }\end{array}$ & $\begin{array}{l}\text { Slurry } \\
\text { Properties } \\
\text { (fluid, } \\
\text { density) }\end{array}$ & $\begin{array}{l}\text { Pre-Injection } \\
\text { Processing/ } \\
\text { Treatment }\end{array}$ & Problems Experienced & Costs & Other Comments \\
\hline \begin{tabular}{|l} 
Alaska/North \\
Slope/Alpine/CD1-05
\end{tabular} & same as Alpine CD1-01 & $386 \mathrm{bbl}$ & & & & & $\begin{array}{l}\text { same as Alpine CD1- } \\
01\end{array}$ \\
\hline $\begin{array}{l}\text { Alaska/North } \\
\text { Slope/Alpine/CD1-13 }\end{array}$ & same as Alpine CD1-01 & $189 \mathrm{bbl}$ & & & & & $\begin{array}{l}\text { same as Alpine CD1- } \\
01\end{array}$ \\
\hline \begin{tabular}{|l} 
Alaska/North \\
Slope/Alpine/CD1-16
\end{tabular} & same as Alpine CD1-01 & $29,050 \mathrm{bbl}$ & & & & & $\begin{array}{l}\text { same as Alpine CD1- } \\
01\end{array}$ \\
\hline $\begin{array}{l}\text { llaska/North } \\
\text { Slope/Alpine/CD1-19 }\end{array}$ & same as Alpine CD1-01 & $34,033 \mathrm{bbl}$ & & & & & $\begin{array}{l}\text { same as Alpine CD1- } \\
01\end{array}$ \\
\hline \begin{tabular}{|l} 
llaska/North \\
Slope/Alpine/CD1-23
\end{tabular} & same as Alpine CD1-01 & $33,986 \mathrm{bbl}$ & & & & & $\begin{array}{l}\text { same as Alpine CD1- } \\
01\end{array}$ \\
\hline $\begin{array}{l}\text { Alaska/North } \\
\text { Slope/Alpine/CD1-24 }\end{array}$ & same as Alpine CD1-01 & $3,098 \mathrm{bbl}$ & & & & & $\begin{array}{l}\text { same as Alpine CD1- } \\
01\end{array}$ \\
\hline $\begin{array}{l}\text { Alaska/North } \\
\text { Slope/Alpine/CD1-25 }\end{array}$ & same as Alpine CD1-01 & $33,587 \mathrm{bbl}$ & & & & & $\begin{array}{l}\text { same as Alpine CD1- } \\
01\end{array}$ \\
\hline \begin{tabular}{|l} 
Alaska/North \\
Slope/Alpine/CD1-27
\end{tabular} & same as Alpine CD1-01 & $32,814 \mathrm{bbl}$ & & & & & $\begin{array}{l}\text { same as Alpine CD1- } \\
01\end{array}$ \\
\hline $\begin{array}{l}\text { Alaska/North } \\
\text { Slope/Alpine/CD1-31 }\end{array}$ & same as Alpine CD1-01 & $7,190 \mathrm{bbl}$ & & & & & $\begin{array}{l}\text { same as Alpine CD1- } \\
01\end{array}$ \\
\hline \begin{tabular}{|l} 
Alaska/North \\
Slope/Alpine/CD1-32
\end{tabular} & same as Alpine CD1-01 & $33,513 \mathrm{bbl}$ & & & & & $\begin{array}{l}\text { same as Alpine CD1- } \\
01\end{array}$ \\
\hline \begin{tabular}{|l} 
Alaska/North \\
Slope/Alpine/CD1-34
\end{tabular} & same as Alpine CD1-01 & $378 \mathrm{bbl}$ & & & & & $\begin{array}{l}\text { same as Alpine CD1- } \\
01\end{array}$ \\
\hline \begin{tabular}{|l} 
Alaska/North \\
Slope/Alpine/CD1-35
\end{tabular} & same as Alpine CD1-01 & $317 \mathrm{bbl}$ & & & & & $\begin{array}{l}\text { same as Alpine CD1- } \\
01\end{array}$ \\
\hline \begin{tabular}{|l} 
Alaska/North \\
Slope/Alpine/CD1-36
\end{tabular} & same as Alpine CD1-01 & $33,667 \mathrm{bbl}$ & & & & & $\begin{array}{l}\text { same as Alpine CD1- } \\
01\end{array}$ \\
\hline \begin{tabular}{|l} 
Alaska/North \\
Slope/Alpine/CD1-37
\end{tabular} & same as Alpine CD1-01 & $32,587 \mathrm{bbl}$ & & & & & $\begin{array}{l}\text { same as Alpine CD1- } \\
01\end{array}$ \\
\hline \begin{tabular}{|l|l|l|l} 
llaska/North \\
Slope/Alpine/CD1-38
\end{tabular} & same as Alpine CD1-01 & $20,320 \mathrm{bbl}$ & & & & & $\begin{array}{l}\text { same as Alpine CD1- } \\
01\end{array}$ \\
\hline \begin{tabular}{|l} 
Alaska/North \\
Slope/Alpine/CD1-39
\end{tabular} & same as Alpine CD1-01 & $31,508 \mathrm{bbl}$ & & & & & $\begin{array}{l}\text { same as Alpine CD1- } \\
01\end{array}$ \\
\hline \begin{tabular}{|l|} 
Alaska/North \\
Slope/Alpine/CD1-40
\end{tabular} & same as Alpine CD1-01 & $32,877 \mathrm{bbl}$ & & & & & $\begin{array}{l}\text { same as Alpine CD1- } \\
01\end{array}$ \\
\hline \begin{tabular}{|l} 
Alaska/North \\
Slope/Alpine/CD1-41
\end{tabular} & same as Alpine CD1-01 & $380 \mathrm{bbl}$ & & & & & $\begin{array}{l}\text { same as Alpine CD1- } \\
01\end{array}$ \\
\hline \begin{tabular}{l|} 
Alaska/North \\
Slope/Alpine/CD1-42
\end{tabular} & same as Alpine CD1-01 & $31,334 \mathrm{bbl}$ & & & & & $\begin{array}{l}\text { same as Alpine CD1- } \\
01\end{array}$ \\
\hline $\begin{array}{l}\text { Alaska/North } \\
\text { Slope/Alpine/CD1-43 }\end{array}$ & same as Alpine CD1-01 & $31,037 \mathrm{bbl}$ & & & & & $\begin{array}{l}\text { same as Alpine CD1- } \\
01\end{array}$ \\
\hline \begin{tabular}{|l} 
Alaska/North \\
Slope/Alpine/CD1-44
\end{tabular} & same as Alpine CD1-01 & $31,928 \mathrm{bbl}$ & & & & & $\begin{array}{l}\text { same as Alpine CD1- } \\
01\end{array}$ \\
\hline \begin{tabular}{|l} 
Alaska/North \\
Slope/Alpine/CD1-45
\end{tabular} & same as Alpine CD1-01 & $32,336 \mathrm{bbl}$ & & & & & $\begin{array}{l}\text { same as Alpine CD1- } \\
01\end{array}$ \\
\hline $\begin{array}{l}\text { Alaska/North } \\
\text { Slope/Alpine/CD2-14 }\end{array}$ & same as Alpine CD1-01 & $31,073 \mathrm{bbl}$ & & & & & $\begin{array}{l}\text { same as Alpine CD1- } \\
01\end{array}$ \\
\hline \begin{tabular}{|l} 
Alaska/North \\
Slope/Alpine/CD2-15
\end{tabular} & same as Alpine CD1-01 & $31,652 \mathrm{bbl}$ & & & & & $\begin{array}{l}\text { same as Alpine CD1- } \\
01\end{array}$ \\
\hline \begin{tabular}{|l} 
Alaska/North \\
Slope/Alpine/CD2-17
\end{tabular} & same as Alpine CD1-01 & $15,354 \mathrm{bbl}$ & & & & & $\begin{array}{l}\text { same as Alpine CD1- } \\
01\end{array}$ \\
\hline \begin{tabular}{|l} 
Alaska/North \\
Slope/Alpine/CD2-24
\end{tabular} & same as Alpine CD1-01 & $33,999 \mathrm{bbl}$ & & & & & $\begin{array}{l}\text { same as Alpine CD1- } \\
01\end{array}$ \\
\hline \begin{tabular}{|l} 
Alaska/North \\
Slope/Alpine/CD2-26
\end{tabular} & same as Alpine CD1-01 & $29,626 \mathrm{bbl}$ & & & & & $\begin{array}{l}\text { same as Alpine CD1- } \\
01\end{array}$ \\
\hline \begin{tabular}{|l} 
Alaska/North \\
Slope/Alpine/CD2-32
\end{tabular} & same as Alpine CD1-01 & $31,816 \mathrm{bbl}$ & & & & & $\begin{array}{l}\text { same as Alpine CD1- } \\
01\end{array}$ \\
\hline \begin{tabular}{|l} 
Alaska/North \\
Slope/Alpine/CD2-34
\end{tabular} & same as Alpine CD1-01 & $23,367 \mathrm{bbl}$ & & & & & $\begin{array}{l}\text { same as Alpine CD1- } \\
01\end{array}$ \\
\hline \begin{tabular}{|l} 
Alaska/North \\
Slope/Alpine/CD2-39
\end{tabular} & same as Alpine CD1-01 & $29,945 \mathrm{bbl}$ & & & & & $\begin{array}{l}\text { same as Alpine CD1- } \\
01\end{array}$ \\
\hline \begin{tabular}{|l} 
Alaska/North \\
Slope/Alpine/CD2-42
\end{tabular} & same as Alpine CD1-01 & $33,992 \mathrm{bbl}$ & & & & & $\begin{array}{l}\text { same as Alpine CD1- } \\
01\end{array}$ \\
\hline
\end{tabular}




\begin{tabular}{|c|c|c|c|c|c|c|c|c|c|c|c|c|}
\hline Site Location/Name & $\begin{array}{l}\text { Operator } \\
\text { Generating } \\
\text { Wastes } \\
\end{array}$ & Source of Information & $\begin{array}{l}\text { Service } \\
\text { Company } \\
\text { Doing } \\
\text { Injection } \\
\end{array}$ & $\begin{array}{l}\text { Geology of Injection } \\
\text { Zone (type of rock, } \\
\text { porosity, permeability) }\end{array}$ & $\begin{array}{l}\text { Depth of } \\
\text { Injection Zone }\end{array}$ & $\begin{array}{l}\text { Depth of } \\
\text { Perforations/ } \\
\text { annular } \\
\text { Injection }\end{array}$ & $\begin{array}{l}\text { Geology and } \\
\text { Depth of } \\
\text { Confining } \\
\text { Layer } \\
\end{array}$ & $\begin{array}{l}\text { Other } \\
\text { Geological } \\
\text { Information }\end{array}$ & $\begin{array}{l}\text { Dates and Duration } \\
\text { of Injection }\end{array}$ & Injection Rate & $\begin{array}{l}\text { Injection } \\
\text { Pressure }\end{array}$ & $\begin{array}{l}\text { Type of } \\
\text { Injection }\end{array}$ \\
\hline \begin{tabular}{|l|} 
Alaska/North \\
Slope/Alpine/CD2-45
\end{tabular} & Phillips Alaska & $\begin{array}{l}\text { Regg \& Maunder \& Maunder } \\
(2003)\end{array}$ & & & & & & & & & & annular \\
\hline \begin{tabular}{|l|} 
Alaska/North \\
Slope/Alpine/CD2-47
\end{tabular} & Phillips Alaska & $\begin{array}{l}\text { Regg \& Maunder \& Maunder } \\
(2003)\end{array}$ & & & & & & & & & & annular \\
\hline $\begin{array}{l}\text { Alaska/North } \\
\text { Slope/Alpine/CD2-48 }\end{array}$ & Phillips Alaska & $\begin{array}{l}\text { Regg \& Maunder \& Maunder } \\
\text { (2003) }\end{array}$ & & & & & & & & & & annular \\
\hline $\begin{array}{l}\text { Alaska/North } \\
\text { Slope/Alpine/CD2-49 }\end{array}$ & Phillips Alaska & $\begin{array}{l}\text { Regg \& Maunder \& Maunder } \\
\text { (2003) }\end{array}$ & & & & & & & & & & annular \\
\hline $\begin{array}{l}\text { Alaska/North } \\
\text { Slope/Alpine/CD2-50 }\end{array}$ & Phillips Alaska & $\begin{array}{l}\text { Regg \& Maunder \& Maunder } \\
\text { (2003) }\end{array}$ & & & & & & & & & & annular \\
\hline Alaska/North Slope/Alpine & Phillips Alaska & MI/SWACO (2002) & MI/SWACO & & & & & & $1 / 00-9 / 02$ & $2-4 \mathrm{bbl} / \mathrm{min}$ & & $\begin{array}{l}\text { dedicated } \\
\text { well, tubing } \\
\text { and packer }\end{array}$ \\
\hline Alaska/North Slope/Badami & BPXA & $\begin{array}{l}\text { Syed and Cutler (2001); } \\
\text { Regg \& Maunder \& Maunder } \\
(2003)\end{array}$ & & & $\begin{array}{l}\text { Ugnu formation; } \\
7,000^{\prime} ; \\
\text { permafrost } \\
\text { extends to } 1,835^{\prime}\end{array}$ & $8,390^{\prime}-8,420^{\prime}$ & $\begin{array}{l}\text { Sagavanirktok } \\
\text { formation (see } \\
\text { Pad 3 NW) }\end{array}$ & & $\begin{array}{l}\text { UIC permit granted } \\
8 / 97\end{array}$ & $\begin{array}{l}600 \mathrm{bbl} / \mathrm{day} \\
\text { avg. }\end{array}$ & $\begin{array}{l}\text { typically } \\
1,350-1,450 \\
\text { psi; } 2,150 \\
\text { psi max. }\end{array}$ & $\begin{array}{l}\text { tubing and } \\
\text { packer }\end{array}$ \\
\hline $\begin{array}{l}\text { Alaska/North Slope/Colville } \\
\text { River/\#WD-02 }\end{array}$ & Phillips Alaska & $\begin{array}{l}\text { Syed and Cutler (2001); } \\
\text { Pekich (2002); Regg \& } \\
\text { Maunder \& Maunder (2003) }\end{array}$ & & $\begin{array}{l}\text { upper injection zone is Sag } \\
\text { River formation (fine- } \\
\text { grained, glauconitic } \\
\text { sandstones), avg. } \\
\text { permeability of } 120 \mathrm{md} \text {; } \\
\text { lower injection zone is } \\
\text { Ivishak formation (thick- } \\
\text { bedded conglomerates, } \\
\text { siltstones and mudstones); } \\
\text { separated by Shublick } \\
\text { formation (shale, siltstone, } \\
\text { limestone) }\end{array}$ & $\begin{array}{l}\text {; } \\
\text { Sag River - 8,937' } \\
\text { 8,979'; Ivishak - } \\
\text { 9,446'-10,132' } \\
\end{array}$ & $\begin{array}{l}\text { 'total of 191' } \\
\text { between 9,459'- } \\
10,047 \text { ' }\end{array}$ & $\begin{array}{l}\text { Upper and } \\
\text { Lower Kingak } \\
\text { formation } 7,680^{\prime}- \\
8,938 \text { '; shales } \\
\text { and siltstones }\end{array}$ & $\begin{array}{l}\text { - base of } \\
\text { permafrost is at } \\
900^{\prime}\end{array}$ & $\begin{array}{l}\text { first placed in service } \\
\text { in 5/99 }\end{array}$ & & $\begin{array}{l}\text { 1,450-1,800 } \\
\text { psi (Syed } \\
\text { and Cutler); } \\
\sim 1,100 \text { psi } \\
\text { avg. and } \\
3,774 \text { psi } \\
\text { max. in 1st } \\
\text { Q of 2002 } \\
\text { (Pekich) }\end{array}$ & $\begin{array}{l}\text { tubing and } \\
\text { packer }\end{array}$ \\
\hline $\begin{array}{l}\text { Alaska/North } \\
\text { Slope/Kuparuk/\#1C-11 }\end{array}$ & Phillips Alaska & $\begin{array}{l}\text { Regg \& Maunder \& Maunder } \\
(2003)\end{array}$ & & & & & & & & & & annular \\
\hline $\begin{array}{l}\text { Alaska/North } \\
\text { Slope/Kuparuk/\#1C-12 }\end{array}$ & Phillips Alaska & Pekich (2002) & $\begin{array}{l}\text { Nabors } \\
\text { Alaska } \\
\text { Drilling or } \\
\text { Doyon } \\
\text { Drilling } \\
\end{array}$ & & & & & & $1998-1999$ & & & annular \\
\hline $\begin{array}{l}\text { Alaska/North } \\
\text { Slope/Kuparuk/\#1C-13 }\end{array}$ & Phillips Alaska & Pekich (2002) & \begin{tabular}{|l|} 
same as \\
Kuparuk \#1C- \\
12
\end{tabular} & & & & & & $1998-999$ & & & annular \\
\hline \begin{tabular}{|l|} 
Alaska/North \\
Slope/Kuparuk/\#1C-14
\end{tabular} & Phillips Alaska & $\begin{array}{l}\text { Regg \& Maunder \& Maunder } \\
\text { (2003) }\end{array}$ & & & & & & & & & & \\
\hline $\begin{array}{l}\text { Alaska/North } \\
\text { Slope/Kuparuk/\#1C-15 }\end{array}$ & Phillips Alaska & $\begin{array}{l}\text { Regg \& Maunder \& Maunder } \\
\text { (2003) }\end{array}$ & & & & & & & & & & \\
\hline $\begin{array}{l}\text { Alaska/North } \\
\text { Slope/Kuparuk/\#1C-16 }\end{array}$ & Phillips Alaska & $\begin{array}{l}\text { Regg \& Maunder \& Maunder } \\
\text { (2003) }\end{array}$ & & & & & & & & & & \\
\hline $\begin{array}{l}\text { Alaska/North } \\
\text { Slope/Kuparuk/\#1C-17 }\end{array}$ & Phillips Alaska & $\begin{array}{l}\text { Regg \& Maunder \& Maunder } \\
\text { (2003) }\end{array}$ & & & & & & & & & & \\
\hline \begin{tabular}{|l|} 
Alaska/North \\
Slope/Kuparuk/\#1C-18
\end{tabular} & Phillips Alaska & $\begin{array}{l}\text { Regg \& Maunder \& Maunder } \\
\text { (2003) }\end{array}$ & & & & & & & & & & \\
\hline $\begin{array}{l}\text { Alaska/North } \\
\text { Slope/Kuparuk/\#1C-23 }\end{array}$ & Phillips Alaska & $\begin{array}{l}\text { Regg \& Maunder \& Maunder } \\
\text { (2003) }\end{array}$ & & & & & & & & & & \\
\hline \begin{tabular}{|l|} 
Alaska/North \\
Slope/Kuparuk/\#1C-25
\end{tabular} & Phillips Alaska & $\begin{array}{l}\text { Regg \& Maunder \& Maunder } \\
\text { (2003) }\end{array}$ & & & & & & & & & & \\
\hline
\end{tabular}




\begin{tabular}{|c|c|c|c|c|c|c|c|}
\hline Site Location/Name & Type of Waste Injected & $\begin{array}{l}\text { Volume of } \\
\text { Material } \\
\text { Injected }\end{array}$ & $\begin{array}{l}\text { Slurry } \\
\text { Properties } \\
\text { (fluid, } \\
\text { density) }\end{array}$ & $\begin{array}{l}\text { Pre-Injection } \\
\text { Processing/ } \\
\text { Treatment }\end{array}$ & Problems Experienced & Costs & Other Comments \\
\hline $\begin{array}{l}\text { Alaska/North } \\
\text { Slope/Alpine/CD2-45 }\end{array}$ & same as Alpine CD1-01 & $22,991 \mathrm{bbl}$ & & & & & $\begin{array}{l}\text { same as Alpine CD1- } \\
01\end{array}$ \\
\hline $\begin{array}{l}\text { Alaska/North } \\
\text { Slope/Alpine/CD2-47 }\end{array}$ & same as Alpine CD1-01 & $27,349 \mathrm{bbl}$ & & & & & $\begin{array}{l}\text { same as Alpine CD1- } \\
01\end{array}$ \\
\hline $\begin{array}{l}\text { Alaska/North } \\
\text { Slope/Alpine/CD2-48 }\end{array}$ & same as Alpine CD1-01 & $11,756 \mathrm{bbl}$ & & & & & $\begin{array}{l}\text { same as Alpine CD1- } \\
01\end{array}$ \\
\hline $\begin{array}{l}\text { Alaska/North } \\
\text { Slope/Alpine/CD2-49 }\end{array}$ & same as Alpine CD1-01 & $27,960 \mathrm{bbl}$ & & & & & $\begin{array}{l}\text { same as Alpine CD1- } \\
01\end{array}$ \\
\hline $\begin{array}{l}\text { Alaska/North } \\
\text { Slope/Alpine/CD2-50 }\end{array}$ & same as Alpine CD1-01 & $32,000 \mathrm{bbl}$ & & & & & $\begin{array}{l}\text { same as Alpine CD1- } \\
01\end{array}$ \\
\hline Alaska/North Slope/Alpine & water-based cuttings & $>558,959 \mathrm{bbl}$ & & gel \& extender & & & $\begin{array}{l}\text { same as } \\
\text { Alaska/North } \\
\text { Slope/Alpine }\end{array}$ \\
\hline Alaska/North Slope/Badami & $\begin{array}{l}\text { seawater and brine, fresh } \\
\text { water, sewage, workover } \\
\text { fluids, crude oil, spent } \\
\text { acid, vessel sludge/sand, } \\
\text { methanol, frac sand, } \\
\text { cement, snow melt, drilling } \\
\text { muds and cuttings }\end{array}$ & $\begin{array}{l}71,634 \text { bbl } \\
\text { during 2001- } \\
2002\end{array}$ & & $\begin{array}{l}\text { solids are ground } \\
\text { in ball mill }\end{array}$ & & & $\begin{array}{l}<0.1 \% \text { of total } \\
\text { injected volume is } \\
\text { solids - mostly } \\
\text { liquids; permitted as } \\
\text { a Class I } \\
\text { nonhazardous well }\end{array}$ \\
\hline $\begin{array}{l}\text { Alaska/North Slope/Colville } \\
\text { River/\#WD-02 }\end{array}$ & $\begin{array}{l}\text { authorized for production, } \\
\text { maintenance, sewage, } \\
\text { and drilling wastes; in 3rd } \\
\text { Q of } 1999, \text { over } 99 \% \text { of } \\
\text { volume was camp } \\
\text { wastewater (very little } \\
\text { drilling waste) }\end{array}$ & $\begin{array}{l}15,000 \\
\text { bbl/month (Syed } \\
\text { and Cutler); } \\
\text { 23,000 } \\
\text { bbl/month in 1st } \\
\text { Q of } 2002 \\
\text { (Pekich) }\end{array}$ & & & & & \begin{tabular}{l|} 
very little solid \\
drilling waste \\
injected into this well; \\
permitted as a Class \\
I nonhazardous well
\end{tabular} \\
\hline $\begin{array}{l}\text { Alaska/North } \\
\text { Slope/Kuparuk/\#1C-11 }\end{array}$ & & $34,985 \mathrm{bbl}$ & & $\begin{array}{l}\text { pumped directly } \\
\text { from rig mud } \\
\text { system to annulus } \\
\text { of most recently } \\
\text { drilled well }\end{array}$ & & & $\begin{array}{l}\text { well received } \\
\text { cuttings from } 1 \text { or } \\
\text { more other wells }\end{array}$ \\
\hline $\begin{array}{l}\text { Alaska/North } \\
\text { Slope/Kuparuk/\#1C-12 }\end{array}$ & same as Alpine CD1-01 & $\begin{array}{l}\text { a) } 34,995 \mathrm{bbl} \text {; b) } \\
100 \mathrm{bbl}\end{array}$ & & & & & $\begin{array}{l}\text { same as Alpine CD1- } \\
01\end{array}$ \\
\hline $\begin{array}{l}\text { Alaska/North } \\
\text { Slope/Kuparuk/\#1C-13 }\end{array}$ & same as Alpine CD1-01 & $\begin{array}{l}\text { a) } 26,800 \mathrm{bbl} \text {; b) } \\
100 \mathrm{bbl}\end{array}$ & & $\begin{array}{l}\text { same as Kuparuk } \\
\# 1 \mathrm{C}-11\end{array}$ & & & $\begin{array}{l}\text { same as Alpine CD1- } \\
01\end{array}$ \\
\hline $\begin{array}{l}\text { Alaska/North } \\
\text { Slope/Kuparuk/\#1C-14 }\end{array}$ & same as Alpine CD1-01 & $32,215 \mathrm{bbl}$ & & & & & $\begin{array}{l}\text { same as Alpine CD1- } \\
01\end{array}$ \\
\hline $\begin{array}{l}\text { Alaska/North } \\
\text { Slope/Kuparuk/\#1C-15 }\end{array}$ & same as Alpine CD1-01 & $48,990 \mathrm{bbl}$ & & & & & $\begin{array}{l}\text { same as Alpine CD1- } \\
01\end{array}$ \\
\hline $\begin{array}{l}\text { Alaska/North } \\
\text { Slope/Kuparuk/\#1C-16 }\end{array}$ & same as Alpine CD1-01 & $32,117 \mathrm{bbl}$ & & & & & $\begin{array}{l}\text { same as Alpine CD1- } \\
01\end{array}$ \\
\hline $\begin{array}{l}\text { Alaska/North } \\
\text { Slope/Kuparuk/\#1C-17 }\end{array}$ & same as Alpine CD1-01 & $33,399 \mathrm{bbl}$ & & & & & $\begin{array}{l}\text { same as Alpine CD1- } \\
01\end{array}$ \\
\hline $\begin{array}{l}\text { Alaska/North } \\
\text { Slope/Kuparuk/\#1C-18 }\end{array}$ & same as Alpine CD1-01 & $32,724 \mathrm{bbl}$ & & & & & $\begin{array}{l}\text { same as Alpine CD1- } \\
01\end{array}$ \\
\hline $\begin{array}{l}\text { Alaska/North } \\
\text { Slope/Kuparuk/\#1C-23 }\end{array}$ & same as Alpine CD1-01 & $34,570 \mathrm{bbl}$ & & & & & $\begin{array}{l}\text { same as Alpine CD1- } \\
01\end{array}$ \\
\hline $\begin{array}{l}\text { Alaska/North } \\
\text { Slope/Kuparuk/\#1C-25 }\end{array}$ & same as Alpine CD1-01 & $34,936 \mathrm{bbl}$ & & & & & $\begin{array}{l}\text { same as Alpine CD1- } \\
01\end{array}$ \\
\hline
\end{tabular}




\begin{tabular}{|c|c|c|c|c|c|c|c|c|c|c|c|c|}
\hline Site Location/Name & $\begin{array}{l}\text { Operator } \\
\text { Generating } \\
\text { Wastes }\end{array}$ & Source of Information & $\begin{array}{l}\text { Service } \\
\text { Company } \\
\text { Doing } \\
\text { Injection }\end{array}$ & $\begin{array}{l}\text { Geology of Injection } \\
\text { Zone (type of rock, } \\
\text { porosity, permeability) }\end{array}$ & $\begin{array}{l}\text { Depth of } \\
\text { Injection Zone }\end{array}$ & $\begin{array}{l}\text { Depth of } \\
\text { Perforations/ } \\
\text { annular } \\
\text { Injection }\end{array}$ & $\begin{array}{l}\text { Geology and } \\
\text { Depth of } \\
\text { Confining } \\
\text { Layer }\end{array}$ & $\begin{array}{l}\text { Other } \\
\text { Geological } \\
\text { Information }\end{array}$ & $\begin{array}{l}\text { Dates and Duration } \\
\text { of Injection }\end{array}$ & Injection Rate & $\begin{array}{l}\text { Injection } \\
\text { Pressure }\end{array}$ & $\begin{array}{l}\text { Type of } \\
\text { Injection }\end{array}$ \\
\hline $\begin{array}{l}\begin{array}{l}\text { Alaska/North } \\
\text { Slope/Kuparuk/\#1C-26 }\end{array} \\
\end{array}$ & Phillips Alaska & $\begin{array}{l}\text { Regg \& Maunder \& Maunder } \\
(2003)\end{array}$ & & & & & & & & & & \\
\hline \begin{tabular}{|l|} 
Alaska/North \\
Slope/Kuparuk/\#1C-27
\end{tabular} & Phillips Alaska & $\begin{array}{l}\text { Regg \& Maunder \& Maunder } \\
(2003)\end{array}$ & & & & & & & & & & \\
\hline \begin{tabular}{|l} 
Alaska/North \\
Slope/Kuparuk/\#CD1-27
\end{tabular} & Phillips Alaska & Pekich (2002) & $\begin{array}{l}\text { same as } \\
\text { Kuparuk \#1C- } \\
12\end{array}$ & & & & & & $5 / 00-6 / 00$ & & & annular \\
\hline $\begin{array}{l}\text { Alaska/North } \\
\text { Slope/Kuparuk/\#1D-10 }\end{array}$ & Phillips Alaska & Pekich (2002) & $\begin{array}{l}\text { same as } \\
\text { Kuparuk \#1C- } \\
12\end{array}$ & & & & & & $1998-1999$ & & & annular \\
\hline $\begin{array}{l}\text { Alaska/North } \\
\text { Slope/Kuparuk/\#1D-11 }\end{array}$ & Phillips Alaska & Pekich (2002) & $\begin{array}{l}\text { same as } \\
\text { Kuparuk \#1C- } \\
12\end{array}$ & & & & & & $6 / 00$ & & & annular \\
\hline $\begin{array}{l}\text { Alaska/North } \\
\text { Slope/Kuparuk/\#1D-12 }\end{array}$ & Phillips Alaska & $\begin{array}{l}\text { Regg \& Maunder \& Maunder } \\
\text { (2003) }\end{array}$ & & & & & & & & & & annular \\
\hline $\begin{array}{l}\text { Alaska/North } \\
\text { Slope/Kuparuk/\#1D-14 }\end{array}$ & Phillips Alaska & Pekich (2002) & $\begin{array}{l}\text { same as } \\
\text { Kuparuk \#1C- } \\
12\end{array}$ & & & & & & $6 / 00-7 / 00$ & & & annular \\
\hline $\begin{array}{l}\text { Alaska/North } \\
\text { Slope/Kuparuk/\#1D-30 }\end{array}$ & Phillips Alaska & Pekich (2002) & $\begin{array}{l}\text { same as } \\
\text { Kuparuk \#1C- } \\
12\end{array}$ & & & & & & $9 / 00-10 / 00$ & & & annular \\
\hline $\begin{array}{l}\text { Alaska/North } \\
\text { Slope/Kuparuk/\#1D-32 }\end{array}$ & Phillips Alaska & Pekich (2002) & $\begin{array}{l}\text { same as } \\
\text { Kuparuk \#1C- } \\
12\end{array}$ & & & & & & $1 / 01-2 / 01$ & & & annular \\
\hline $\begin{array}{l}\text { Alaska/North } \\
\text { Slope/Kuparuk/\#1D-34 }\end{array}$ & Phillips Alaska & Pekich (2002) & $\begin{array}{l}\text { same as } \\
\text { Kuparuk \#1C- } \\
12\end{array}$ & & & & & & $11 / 00-12 / 00$ & & & annular \\
\hline $\begin{array}{l}\text { Alaska/North } \\
\text { Slope/Kuparuk/\#1D-36 }\end{array}$ & Phillips Alaska & Pekich (2002) & $\begin{array}{l}\text { same as } \\
\text { Kuparuk \#1C- } \\
12\end{array}$ & & & & & & $10 / 00-11 / 00$ & & & annular \\
\hline $\begin{array}{l}\text { Alaska/North } \\
\text { Slope/Kuparuk/\#1D-38 }\end{array}$ & Phillips Alaska & Pekich (2002) & $\begin{array}{l}\text { same as } \\
\text { Kuparuk \#1C- } \\
12\end{array}$ & & & & & & $7 / 00-9 / 00$ & & & annular \\
\hline $\begin{array}{l}\text { Alaska/North } \\
\text { Slope/Kuparuk/\#1D-42 }\end{array}$ & Phillips Alaska & Pekich (2002) & \begin{tabular}{|l|} 
same as \\
Kuparuk \#1C- \\
12
\end{tabular} & & & & & & $12 / 00-1 / 01$ & & & annular \\
\hline \begin{tabular}{|l|} 
Alaska/North \\
Slope/Kuparuk/\#1E-31
\end{tabular} & Phillips Alaska & $\begin{array}{l}\text { Regg \& Maunder \& Maunder } \\
(2003)\end{array}$ & & & & & & & & & & annular \\
\hline \begin{tabular}{|l|} 
Alaska/North \\
Slope/Kuparuk/\#1E-32
\end{tabular} & Phillips Alaska & $\begin{array}{l}\text { Regg \& Maunder \& Maunder } \\
\text { (2003) }\end{array}$ & & & & & & & & & & annular \\
\hline $\begin{array}{l}\text { Alaska/North } \\
\text { Slope/Kuparuk/\#1F-18 }\end{array}$ & Phillips Alaska & $\begin{array}{l}\text { Regg \& Maunder \& Maunder } \\
\text { (2003) }\end{array}$ & & & & & & & & & & annular \\
\hline $\begin{array}{l}\text { Alaska/North } \\
\text { Slope/Kuparuk/\#1F-19 }\end{array}$ & Phillips Alaska & $\begin{array}{l}\text { Regg \& Maunder \& Maunder } \\
(2003)\end{array}$ & & & & & & & & & & annular \\
\hline $\begin{array}{l}\text { Alaska/North } \\
\text { Slope/Kuparuk/\#1J-03 }\end{array}$ & Phillips Alaska & Pekich (2002) & $\begin{array}{l}\text { same as } \\
\# 1 C-12\end{array}$ & & & & & & $3 / 01-5 / 01$ & & & annular \\
\hline $\begin{array}{l}\text { Alaska/North } \\
\text { Slope/Kuparuk/\#1J-09 }\end{array}$ & Phillips Alaska & $\begin{array}{l}\text { Regg \& Maunder \& Maunder } \\
\text { (2003) }\end{array}$ & & & & & & & & & & annular \\
\hline $\begin{array}{l}\text { Alaska/North } \\
\text { Slope/Kuparuk/\#1L-28 }\end{array}$ & Phillips Alaska & Pekich (2002) & $\begin{array}{l}\text { same as } \\
\# 1 C-12\end{array}$ & & & & & & $3 / 00-4 / 00$ & & & annular \\
\hline \begin{tabular}{|l|} 
Alaska/North \\
Slope/Kuparuk/\#1Q-24
\end{tabular} & Phillips Alaska & $\begin{array}{l}\text { Regg \& Maunder \& Maunder } \\
(2003)\end{array}$ & & & & & & & & & & annular \\
\hline $\begin{array}{l}\text { Alaska/North } \\
\text { Slope/Kuparuk/\#1Q-26 }\end{array}$ & Phillips Alaska & $\begin{array}{l}\text { Regg \& Maunder \& Maunder } \\
\text { (2003) }\end{array}$ & & & & & & & & & & annular \\
\hline $\begin{array}{l}\text { Alaska/North } \\
\text { Slope/Kuparuk/\#2A-18 }\end{array}$ & Phillips Alaska & $\begin{array}{l}\text { Regg \& Maunder \& Maunder } \\
(2003)\end{array}$ & & & & & & & & & & annular \\
\hline \begin{tabular}{|l|} 
Alaska/North \\
Slope/Kuparuk/\#2A-22
\end{tabular} & Phillips Alaska & $\begin{array}{l}\text { Regg \& Maunder \& Maunder } \\
\text { (2003) }\end{array}$ & & & & & & & & & & annular \\
\hline $\begin{array}{l}\text { Alaska/North } \\
\text { Slope/Kuparuk/\#2F-05X }\end{array}$ & Phillips Alaska & $\begin{array}{l}\text { Regg \& Maunder \& Maunder } \\
\text { (2003) }\end{array}$ & & & & & & & & & & annular \\
\hline \begin{tabular}{|l|} 
Alaska/North \\
Slope/Kuparuk/\#2F-18
\end{tabular} & Phillips Alaska & $\begin{array}{l}\text { Regg \& Maunder \& Maunder } \\
\text { (2003) }\end{array}$ & & & & & & & & & & annular \\
\hline
\end{tabular}




\begin{tabular}{|c|c|c|c|c|c|c|c|}
\hline Site Location/Name & Type of Waste Injected & $\begin{array}{l}\text { Volume of } \\
\text { Material } \\
\text { Injected }\end{array}$ & $\begin{array}{l}\text { Slurry } \\
\text { Properties } \\
\text { (fluid, } \\
\text { density) }\end{array}$ & $\begin{array}{l}\text { Pre-Injection } \\
\text { Processing/ } \\
\text { Treatment }\end{array}$ & Problems Experienced & Costs & Other Comments \\
\hline $\begin{array}{l}\text { Alaska/North } \\
\text { Slope/Kuparuk/\#1C-26 }\end{array}$ & same as Alpine CD1-01 & $34,260 \mathrm{bbl}$ & & & & & $\begin{array}{l}\text { same as Alpine CD1- } \\
01\end{array}$ \\
\hline \begin{tabular}{|l|} 
Alaska/North \\
Slope/Kuparuk/\#1C-27
\end{tabular} & same as Alpine CD1-01 & $32,019 \mathrm{bbl}$ & & & & & $\begin{array}{l}\text { same as Alpine CD1- } \\
01\end{array}$ \\
\hline $\begin{array}{l}\text { Alaska/North } \\
\text { Slope/Kuparuk/\#CD1-27 }\end{array}$ & same as Alpine CD1-01 & $\begin{array}{l}\text { a) } 32,714 \mathrm{bbl} \text {; b) } \\
100 \mathrm{bbl}\end{array}$ & & $\begin{array}{l}\text { same as Kuparuk } \\
\# 1 C-11\end{array}$ & & & $\begin{array}{l}\text { same as Alpine CD1- } \\
01\end{array}$ \\
\hline $\begin{array}{l}\text { Alaska/North } \\
\text { Slope/Kuparuk/\#1D-10 }\end{array}$ & same as Alpine CD1-01 & $\begin{array}{l}\text { a) } 35,473 \mathrm{bbl} \text {; b) } \\
100 \mathrm{bbl}\end{array}$ & & $\begin{array}{l}\text { same as Kuparuk } \\
\# 1 \mathrm{C}-11\end{array}$ & & & $\begin{array}{l}\text { same as Alpine CD1- } \\
01\end{array}$ \\
\hline $\begin{array}{l}\text { Alaska/North } \\
\text { Slope/Kuparuk/\#1D-11 }\end{array}$ & same as Alpine CD1-01 & $\begin{array}{l}\text { a) } 135 \mathrm{bbl} \text {; b) } \\
100 \mathrm{bbl}\end{array}$ & & $\begin{array}{l}\text { same as Kuparuk } \\
\# 1 \mathrm{C}-11\end{array}$ & & & $\begin{array}{l}\text { same as Alpine CD1- } \\
01\end{array}$ \\
\hline $\begin{array}{l}\text { Alaska/North } \\
\text { Slope/Kuparuk/\#1D-12 }\end{array}$ & same as Alpine CD1-01 & $32,891 \mathrm{bbl}$ & & & & & $\begin{array}{l}\text { same as Alpine CD1- } \\
01\end{array}$ \\
\hline $\begin{array}{l}\text { Alaska/North } \\
\text { Slope/Kuparuk/\#1D-14 }\end{array}$ & same as Alpine CD1-01 & $\begin{array}{l}\text { a) } 35,404 \mathrm{bbl} \text {; b) } \\
100 \mathrm{bbl}\end{array}$ & & $\begin{array}{l}\text { same as Kuparuk } \\
\# 1 \mathrm{C}-11\end{array}$ & & & $\begin{array}{l}\text { same as Alpine CD1- } \\
01\end{array}$ \\
\hline \begin{tabular}{|l} 
Alaska/North \\
Slope/Kuparuk/\#1D-30
\end{tabular} & same as Alpine CD1-01 & $\begin{array}{l}\text { a) } 31,622 \mathrm{bbl} \text {; b) } \\
100 \mathrm{bbl}\end{array}$ & & $\begin{array}{l}\text { same as Kuparuk } \\
\# 1 \mathrm{C}-11\end{array}$ & & & $\begin{array}{l}\text { same as Alpine CD1- } \\
01\end{array}$ \\
\hline \begin{tabular}{|l} 
Alaska/North \\
Slope/Kuparuk/\#1D-32
\end{tabular} & same as Alpine CD1-01 & $\begin{array}{l}\text { a) } 23,162 \mathrm{bbl} ; \mathrm{b}) \\
100 \mathrm{bbl}\end{array}$ & & $\begin{array}{l}\text { same as Kuparuk } \\
\# 1 \mathrm{C}-11\end{array}$ & & & $\begin{array}{l}\text { same as Alpine CD1- } \\
01\end{array}$ \\
\hline $\begin{array}{l}\text { Alaska/North } \\
\text { Slope/Kuparuk/\#1D-34 }\end{array}$ & same as Alpine CD1-01 & $\begin{array}{l}\text { a) } 31,915 \mathrm{bbl} \text {; b) } \\
100 \mathrm{bbl}\end{array}$ & & $\begin{array}{l}\text { same as Kuparuk } \\
\# 1 C-11\end{array}$ & & & $\begin{array}{l}\text { same as Alpine CD1- } \\
01\end{array}$ \\
\hline $\begin{array}{l}\text { Alaska/North } \\
\text { Slope/Kuparuk/\#1D-36 }\end{array}$ & same as Alpine CD1-01 & $\begin{array}{l}\text { a) } 30,104 \mathrm{bbl} ; \mathrm{b}) \\
100 \mathrm{bbl}\end{array}$ & & $\begin{array}{l}\text { same as Kuparuk } \\
\# 1 \mathrm{C}-11\end{array}$ & & & $\begin{array}{l}\text { same as Alpine CD1- } \\
01\end{array}$ \\
\hline $\begin{array}{l}\text { Alaska/North } \\
\text { Slope/Kuparuk/\#1D-38 }\end{array}$ & same as Alpine CD1-01 & $\begin{array}{l}\text { a) } 33,907 \mathrm{bbl} \text {; b) } \\
100 \mathrm{bbl}\end{array}$ & & $\begin{array}{l}\text { same as Kuparuk } \\
\# 1 \mathrm{C}-11\end{array}$ & & & $\begin{array}{l}\text { same as Alpine CD1- } \\
01\end{array}$ \\
\hline $\begin{array}{l}\text { Alaska/North } \\
\text { Slope/Kuparuk/\#1D-42 }\end{array}$ & same as Alpine CD1-01 & $\begin{array}{l}\text { a) } 32,040 \mathrm{bbl} ; \mathrm{b}) \\
100 \mathrm{bbl}\end{array}$ & & $\begin{array}{l}\text { same as Kuparuk } \\
\# 1 \mathrm{C}-11\end{array}$ & & & $\begin{array}{l}\text { same as Alpine CD1- } \\
01\end{array}$ \\
\hline $\begin{array}{l}\text { Alaska/North } \\
\text { Slope/Kuparuk/\#1E-31 }\end{array}$ & same as Alpine CD1-01 & $33,745 \mathrm{bbl}$ & & & & & $\begin{array}{l}\text { same as Alpine CD1- } \\
01\end{array}$ \\
\hline \begin{tabular}{|l} 
Alaska/North \\
Slope/Kuparuk/\#1E-32
\end{tabular} & same as Alpine CD1-01 & $45,305 \mathrm{bbl}$ & & & & & $\begin{array}{l}\text { same as Alpine CD1- } \\
01\end{array}$ \\
\hline $\begin{array}{l}\text { Alaska/North } \\
\text { Slope/Kuparuk/\#1F-18 }\end{array}$ & same as Alpine CD1-01 & $24,777 \mathrm{bbl}$ & & & & & $\begin{array}{l}\text { same as Alpine CD1- } \\
01\end{array}$ \\
\hline \begin{tabular}{|l|} 
Alaska/North \\
Slope/Kuparuk/\#1F-19
\end{tabular} & same as Alpine CD1-01 & $5,040 \mathrm{bbl}$ & & & & & $\begin{array}{l}\text { same as Alpine CD1- } \\
01\end{array}$ \\
\hline $\begin{array}{l}\text { Alaska/North } \\
\text { Slope/Kuparuk/\#1J-03 }\end{array}$ & same as Alpine CD1-01 & $\begin{array}{l}\text { a) } 30,024 \mathrm{bbl} ; \mathrm{b}) \\
100 \mathrm{bbl}\end{array}$ & & $\begin{array}{l}\text { same as Kuparuk } \\
\# 1 \mathrm{C}-11\end{array}$ & & & $\begin{array}{l}\text { same as Alpine CD1- } \\
01\end{array}$ \\
\hline $\begin{array}{l}\text { Alaska/North } \\
\text { Slope/Kuparuk/\#1J-09 }\end{array}$ & same as Alpine CD1-01 & $24,632 \mathrm{bbl}$ & & & & & $\begin{array}{l}\text { same as Alpine CD1- } \\
01\end{array}$ \\
\hline \begin{tabular}{|l|} 
Alaska/North \\
Slope/Kuparuk/\#1L-28
\end{tabular} & same as Alpine CD1-01 & $\begin{array}{l}\text { a) } 9,837 \mathrm{bbl} ; \mathrm{b}) \\
100 \mathrm{bbl}\end{array}$ & & $\begin{array}{l}\text { same as Kuparuk } \\
\# 1 C-11\end{array}$ & & & $\begin{array}{l}\text { same as Alpine CD1- } \\
01\end{array}$ \\
\hline $\begin{array}{l}\text { Alaska/North } \\
\text { Slope/Kuparuk/\#1Q-24 }\end{array}$ & same as Alpine CD1-01 & $23,258 \mathrm{bbl}$ & & & & & $\begin{array}{l}\text { same as Alpine CD1- } \\
01\end{array}$ \\
\hline \begin{tabular}{|l|} 
Alaska/North \\
Slope/Kuparuk/\#1Q-26
\end{tabular} & same as Alpine CD1-01 & $26,031 \mathrm{bbl}$ & & & & & $\begin{array}{l}\text { same as Alpine CD1- } \\
01\end{array}$ \\
\hline \begin{tabular}{|l|} 
Alaska/North \\
Slope/Kuparuk/\#2A-18
\end{tabular} & same as Alpine CD1-01 & $16,284 \mathrm{bbl}$ & & & & & $\begin{array}{l}\text { same as Alpine CD1- } \\
01\end{array}$ \\
\hline $\begin{array}{l}\text { Alaska/North } \\
\text { Slope/Kuparuk/\#2A-22 }\end{array}$ & same as Alpine CD1-01 & $16,849 \mathrm{bbl}$ & & & & & $\begin{array}{l}\text { same as Alpine CD1- } \\
01\end{array}$ \\
\hline \begin{tabular}{|l} 
Alaska/North \\
Slope/Kuparuk/\#2F-05X
\end{tabular} & same as Alpine CD1-01 & $13,840 \mathrm{bbl}$ & & & & & $\begin{array}{l}\text { same as Alpine CD1- } \\
01\end{array}$ \\
\hline \begin{tabular}{|l|}
$\begin{array}{l}\text { Alaska/North } \\
\text { Slope/Kuparuk/\#2F-18 }\end{array}$ \\
\end{tabular} & same as Alpine CD1-01 & $26,356 \mathrm{bbl}$ & & & & & $\begin{array}{l}\text { same as Alpine CD1- } \\
01\end{array}$ \\
\hline
\end{tabular}




\begin{tabular}{|c|c|c|c|c|c|c|c|c|c|c|c|c|}
\hline Site Location/Name & $\begin{array}{l}\text { Operator } \\
\text { Generating } \\
\text { Wastes }\end{array}$ & Source of Information & $\begin{array}{l}\text { Service } \\
\text { Company } \\
\text { Doing } \\
\text { Injection }\end{array}$ & $\begin{array}{l}\text { Geology of Injection } \\
\text { Zone (type of rock, } \\
\text { porosity, permeability) }\end{array}$ & $\begin{array}{l}\text { Depth of } \\
\text { Injection Zone }\end{array}$ & $\begin{array}{l}\text { Depth of } \\
\text { Perforations/ } \\
\text { annular } \\
\text { Injection }\end{array}$ & $\begin{array}{l}\text { Geology and } \\
\text { Depth of } \\
\text { Confining } \\
\text { Layer }\end{array}$ & $\begin{array}{l}\text { Other } \\
\text { Geological } \\
\text { Information }\end{array}$ & $\begin{array}{l}\text { Dates and Duration } \\
\text { of Injection }\end{array}$ & Injection Rate & $\begin{array}{l}\text { Injection } \\
\text { Pressure }\end{array}$ & $\begin{array}{l}\text { Type of } \\
\text { Injection }\end{array}$ \\
\hline $\begin{array}{l}\text { Alaska/North } \\
\text { Slope/Kuparuk/\#2F-19 }\end{array}$ & Phillips Alaska & $\begin{array}{l}\text { Regg \& Maunder \& Maunder } \\
\text { (2003) }\end{array}$ & & & & & & & & & & annular \\
\hline $\begin{array}{l}\text { Alaska/North } \\
\text { Slope/Kuparuk/\#2L-313 }\end{array}$ & Phillips Alaska & Pekich (2002) & $\begin{array}{l}\text { same as } \\
\# 1 C-12\end{array}$ & & & & & & $3 / 99-12 / 00$ & & & annular \\
\hline $\begin{array}{l}\text { Alaska/North } \\
\text { Slope/Kuparuk/\#2L-325 }\end{array}$ & Phillips Alaska & $\begin{array}{l}\text { Regg \& Maunder \& Maunder } \\
\text { (2003) }\end{array}$ & & & & & & & & & & annular \\
\hline \begin{tabular}{|l|} 
Alaska/North \\
Slope/Kuparuk/\#2L-329A
\end{tabular} & Phillips Alaska & $\begin{array}{l}\text { Regg \& Maunder \& Maunder } \\
\text { (2003) }\end{array}$ & & & & & & & & & & annular \\
\hline $\begin{array}{l}\text { Alaska/North } \\
\text { Slope/Kuparuk/\#2M-31 }\end{array}$ & Phillips Alaska & $\begin{array}{l}\text { Regg \& Maunder \& Maunder } \\
\text { (2003) }\end{array}$ & & & & & & & & & & annular \\
\hline \begin{tabular}{|l|} 
Alaska/North \\
Slope/Kuparuk/\#2M-33
\end{tabular} & Phillips Alaska & $\begin{array}{l}\text { Regg \& Maunder \& Maunder } \\
(2003)\end{array}$ & & & & & & & & & & annular \\
\hline $\begin{array}{l}\text { Alaska/North } \\
\text { Slope/Kuparuk/\#2N-305 }\end{array}$ & Phillips Alaska & $\begin{array}{l}\text { Regg \& Maunder \& Maunder } \\
(2003)\end{array}$ & & & & & & & & & & annular \\
\hline \begin{tabular}{|l|} 
Alaska/North \\
Slope/Kuparuk/\#2N-313
\end{tabular} & Phillips Alaska & $\begin{array}{l}\text { Regg \& Maunder \& Maunder } \\
\text { (2003) }\end{array}$ & & & & & & & & & & annular \\
\hline $\begin{array}{l}\text { Alaska/North } \\
\text { Slope/Kuparuk/\#2N-315 }\end{array}$ & Phillips Alaska & $\begin{array}{l}\text { Regg \& Maunder \& Maunder } \\
\text { (2003) }\end{array}$ & & & & & & & & & & annular \\
\hline \begin{tabular}{|l|} 
Alaska/North \\
Slope/Kuparuk/\#2N-316
\end{tabular} & Phillips Alaska & Pekich (2002) & $\begin{array}{l}\text { same as } \\
\# 1 \mathrm{C}-12\end{array}$ & & & & & & $8 / 00$ & & & annular \\
\hline $\begin{array}{l}\text { Alaska/North } \\
\text { Slope/Kuparuk/\#2N-318 }\end{array}$ & Phillips Alaska & Pekich (2002) & $\begin{array}{l}\text { same as } \\
\# 1 C-12\end{array}$ & & & & & & $12 / 00-7 / 01$ & & & annular \\
\hline $\begin{array}{l}\text { Alaska/North } \\
\text { Slope/Kuparuk/\#2N-321A }\end{array}$ & Phillips Alaska & $\begin{array}{l}\text { Regg \& Maunder \& Maunder } \\
(2003)\end{array}$ & & & & & & & & & & annular \\
\hline $\begin{array}{l}\begin{array}{l}\text { Alaska/North } \\
\text { Slope/Kuparuk/\#2N-323 }\end{array} \\
\end{array}$ & Phillips Alaska & Pekich (2002) & $\begin{array}{l}\text { same as } \\
\# 1 C-12\end{array}$ & & & & & & $1998-1999$ & & & annular \\
\hline $\begin{array}{l}\text { Alaska/North } \\
\text { Slope/Kuparuk/\#2N-329 }\end{array}$ & Phillips Alaska & Pekich (2002) & $\begin{array}{l}\text { same as } \\
\# 1 C-12\end{array}$ & & & & & & $1998-1999$ & & & annular \\
\hline $\begin{array}{l}\text { Alaska/North } \\
\text { Slope/Kuparuk/\#2N-332 }\end{array}$ & Phillips Alaska & Pekich (2002) & $\begin{array}{l}\text { same as } \\
\# 1 C-12\end{array}$ & & & & & & $7 / 00$ & & & annular \\
\hline \begin{tabular}{|l|l|l|l|l} 
Alaska/North \\
Slope/Kuparuk/\#2N-335
\end{tabular} & Phillips Alaska & Regg \& Maunder (2003) & & & & & & & & & & annular \\
\hline \begin{tabular}{|l|} 
Alaska/North \\
Slope/Kuparuk/\#2N-337A
\end{tabular} & Phillips Alaska & Regg \& Maunder (2003) & & & & & & & & & & annular \\
\hline $\begin{array}{l}\text { Alaska/North } \\
\text { Slope/Kuparuk/\#2N-341 }\end{array}$ & Phillips Alaska & Regg \& Maunder (2003) & & & & & & & & & & annular \\
\hline \begin{tabular}{|l|} 
Alaska/North \\
Slope/Kuparuk/\#2N-343
\end{tabular} & Phillips Alaska & Pekich (2002) & $\begin{array}{l}\text { same as } \\
\# 1 C-12\end{array}$ & & & & & & $1998-1999$ & & & annular \\
\hline $\begin{array}{l}\text { Alaska/North } \\
\text { Slope/Kuparuk/\#2N-347 }\end{array}$ & Phillips Alaska & Pekich (2002) & $\begin{array}{l}\text { same as } \\
\# 1 C-12\end{array}$ & & & & & & $9 / 00-9 / 01$ & & & annular \\
\hline $\begin{array}{l}\text { Alaska/North } \\
\text { Slope/Kuparuk/\#2P-415A }\end{array}$ & Phillips Alaska & Regg \& Maunder (2003) & & & & & & & & & & annular \\
\hline \begin{tabular}{|l|} 
Alaska/North \\
Slope/Kuparuk/\#2P-417
\end{tabular} & Phillips Alaska & Regg \& Maunder (2003) & & & & & & & & & & annular \\
\hline \begin{tabular}{|l|} 
Alaska/North \\
Slope/Kuparuk/\#2P-420
\end{tabular} & Phillips Alaska & Regg \& Maunder (2003) & & & & & & & & & & annular \\
\hline $\begin{array}{l}\text { Alaska/North } \\
\text { Slope/Kuparuk/\#2P-438 }\end{array}$ & Phillips Alaska & Regg \& Maunder (2003) & & & & & & & & & & annular \\
\hline \begin{tabular}{|l|} 
Alaska/North \\
Slope/Kuparuk/\#2T-21
\end{tabular} & Phillips Alaska & Regg \& Maunder (2003) & & & & & & & & & & annular \\
\hline $\begin{array}{l}\text { Alaska/North } \\
\text { Slope/Kuparuk/\#2T-32 }\end{array}$ & Phillips Alaska & Regg \& Maunder (2003) & & & & & & & & & & annular \\
\hline $\begin{array}{l}\begin{array}{l}\text { Alaska/North } \\
\text { Slope/Kuparuk/\#2X-17 }\end{array} \\
\end{array}$ & Phillips Alaska & Regg \& Maunder (2003) & & & & & & & & & & annular \\
\hline $\begin{array}{l}\text { Alaska/North } \\
\text { Slope/Kuparuk/\#2X-18 }\end{array}$ & Phillips Alaska & Regg \& Maunder (2003) & & & & & & & & & & annular \\
\hline $\begin{array}{l}\text { Alaska/North } \\
\text { Slope/Kuparuk/\#2Z-22 }\end{array}$ & Phillips Alaska & Regg \& Maunder (2003) & & & & & & & & & & annular \\
\hline $\begin{array}{l}\text { Alaska/North } \\
\text { Slope/Kuparuk/\#3A-17 }\end{array}$ & Phillips Alaska & Regg \& Maunder (2003) & & & & & & & & & & annular \\
\hline $\begin{array}{l}\text { Alaska/North } \\
\text { Slope/Kuparuk/\#3F-19 }\end{array}$ & Phillips Alaska & Regg \& Maunder (2003) & & & & & & & & & & annular \\
\hline
\end{tabular}




\begin{tabular}{|c|c|c|c|c|c|c|c|}
\hline Site Location/Name & Type of Waste Injected & $\begin{array}{l}\text { Volume of } \\
\text { Material } \\
\text { Injected }\end{array}$ & $\begin{array}{l}\text { Slurry } \\
\text { Properties } \\
\text { (fluid, } \\
\text { density) }\end{array}$ & $\begin{array}{l}\text { Pre-Injection } \\
\text { Processing/ } \\
\text { Treatment }\end{array}$ & Problems Experienced & Costs & Other Comments \\
\hline $\begin{array}{l}\text { Alaska/North } \\
\text { Slope/Kuparuk/\#2F-19 }\end{array}$ & same as Alpine CD1-01 & $20,825 \mathrm{bbl}$ & & & & & $\begin{array}{l}\text { same as Alpine CD1- } \\
01\end{array}$ \\
\hline \begin{tabular}{|l|} 
Alaska/North \\
Slope/Kuparuk/\#2L-313
\end{tabular} & same as Alpine CD1-01 & $\begin{array}{l}\text { a) } 26,290 \mathrm{bbl} \text {; b) } \\
100 \mathrm{bbl}\end{array}$ & & $\begin{array}{l}\text { same as Kuparuk } \\
\# 1 \mathrm{C}-11\end{array}$ & & & $\begin{array}{l}\text { same as Alpine CD1- } \\
01\end{array}$ \\
\hline $\begin{array}{l}\text { Alaska/North } \\
\text { Slope/Kuparuk/\#2L-325 }\end{array}$ & same as Alpine CD1-01 & $20,380 \mathrm{bbl}$ & & & & & $\begin{array}{l}\text { same as Alpine CD1- } \\
01\end{array}$ \\
\hline $\begin{array}{l}\text { Alaska/North } \\
\text { Slope/Kuparuk/\#2L-329A }\end{array}$ & same as Alpine CD1-01 & $34,071 \mathrm{bbl}$ & & & & & $\begin{array}{l}\text { same as Alpine CD1- } \\
01\end{array}$ \\
\hline \begin{tabular}{|l|l|} 
Alaska/North \\
Slope/Kuparuk/\#2M-31
\end{tabular} & same as Alpine CD1-01 & $25,088 \mathrm{bbl}$ & & & & & $\begin{array}{l}\text { same as Alpine CD1- } \\
01\end{array}$ \\
\hline $\begin{array}{l}\text { Alaska/North } \\
\text { Slope/Kuparuk/\#2M-33 }\end{array}$ & same as Alpine CD1-01 & $30,201 \mathrm{bbl}$ & & & & & $\begin{array}{l}\text { same as Alpine CD1- } \\
01\end{array}$ \\
\hline $\begin{array}{l}\text { Alaska/North } \\
\text { Slope/Kuparuk/\#2N-305 }\end{array}$ & same as Alpine CD1-01 & $380 \mathrm{bbl}$ & & & & & $\begin{array}{l}\text { same as Alpine CD1- } \\
01\end{array}$ \\
\hline $\begin{array}{l}\text { Alaska/North } \\
\text { Slope/Kuparuk/\#2N-313 }\end{array}$ & same as Alpine CD1-01 & $32,858 \mathrm{bbl}$ & & & & & $\begin{array}{l}\text { same as Alpine CD1- } \\
01\end{array}$ \\
\hline $\begin{array}{l}\text { Alaska/North } \\
\text { Slope/Kuparuk/\#2N-315 }\end{array}$ & same as Alpine CD1-01 & $25,426 \mathrm{bbl}$ & & & & & $\begin{array}{l}\text { same as Alpine CD1- } \\
01\end{array}$ \\
\hline $\begin{array}{l}\text { Alaska/North } \\
\text { Slope/Kuparuk/\#2N-316 }\end{array}$ & same as Alpine CD1-01 & $\begin{array}{l}\text { a) } 240 \mathrm{bbl} \text {; b) } \\
100 \mathrm{bbl}\end{array}$ & & $\begin{array}{l}\text { same as Kuparuk } \\
\# 1 \mathrm{C}-11\end{array}$ & & & $\begin{array}{l}\text { same as Alpine CD1- } \\
01\end{array}$ \\
\hline $\begin{array}{l}\text { Alaska/North } \\
\text { Slope/Kuparuk/\#2N-318 }\end{array}$ & same as Alpine CD1-01 & $\begin{array}{l}\text { a) } 17,498 \mathrm{bbl} \text {; b) } \\
100 \mathrm{bbl}\end{array}$ & & $\begin{array}{l}\text { same as Kuparuk } \\
\# 1 C-11\end{array}$ & & & $\begin{array}{l}\text { same as Alpine CD1- } \\
01\end{array}$ \\
\hline $\begin{array}{l}\text { Alaska/North } \\
\text { Slope/Kuparuk/\#2N-321A }\end{array}$ & same as Alpine CD1-01 & $27,607 \mathrm{bbl}$ & & & & & $\begin{array}{l}\text { same as Alpine CD1- } \\
01\end{array}$ \\
\hline $\begin{array}{l}\text { Alaska/North } \\
\text { Slope/Kuparuk/\#2N-323 }\end{array}$ & same as Alpine CD1-01 & $\begin{array}{l}\text { a) } 32,696 \mathrm{bbl} ; \mathrm{b}) \\
100 \mathrm{bbl}\end{array}$ & & $\begin{array}{l}\text { same as Kuparuk } \\
\# 1 \mathrm{C}-11\end{array}$ & & & $\begin{array}{l}\text { same as Alpine CD1- } \\
01\end{array}$ \\
\hline \begin{tabular}{l|} 
Alaska/North \\
Slope/Kuparuk/\#2N-329
\end{tabular} & same as Alpine CD1-01 & $\begin{array}{l}\text { a) } 9 \text { bbl; b) } 100 \\
\text { bbl }\end{array}$ & & $\begin{array}{l}\text { same as Kuparuk } \\
\# 1 C-11\end{array}$ & & & $\begin{array}{l}\text { same as Alpine CD1- } \\
01\end{array}$ \\
\hline $\begin{array}{l}\text { Alaska/North } \\
\text { Slope/Kuparuk/\#2N-332 }\end{array}$ & same as Alpine CD1-01 & $\begin{array}{l}\text { a) } 225 \mathrm{bbl} \text {; b) } \\
100 \mathrm{bbl}\end{array}$ & & $\begin{array}{l}\text { same as Kuparuk } \\
\# 1 \mathrm{C}-11\end{array}$ & & & $\begin{array}{l}\text { same as Alpine CD1- } \\
01\end{array}$ \\
\hline $\begin{array}{l}\text { Alaska/North } \\
\text { Slope/Kuparuk/\#2N-335 }\end{array}$ & same as Alpine CD1-01 & $25,495 \mathrm{bbl}$ & & & & & $\begin{array}{l}\text { same as Alpine CD1- } \\
01\end{array}$ \\
\hline $\begin{array}{l}\text { Alaska/North } \\
\text { Slope/Kuparuk/\#2N-337A }\end{array}$ & same as Alpine CD1-01 & $30,639 \mathrm{bbl}$ & & & & & $\begin{array}{l}\text { same as Alpine CD1- } \\
01\end{array}$ \\
\hline $\begin{array}{l}\text { Alaska/North } \\
\text { Slope/Kuparuk/\#2N-341 }\end{array}$ & same as Alpine CD1-01 & $34,150 \mathrm{bbl}$ & & & & & $\begin{array}{l}\text { same as Alpine CD1- } \\
01\end{array}$ \\
\hline $\begin{array}{l}\text { Alaska/North } \\
\text { Slope/Kuparuk/\#2N-343 }\end{array}$ & same as Alpine CD1-01 & $\begin{array}{l}\text { a) } 17,895 \mathrm{bbl} ; \mathrm{b}) \\
100 \mathrm{bbl}\end{array}$ & & $\begin{array}{l}\text { same as Kuparuk } \\
\# 1 C-11\end{array}$ & & & $\begin{array}{l}\text { same as Alpine CD1- } \\
01\end{array}$ \\
\hline $\begin{array}{l}\text { Alaska/North } \\
\text { Slope/Kuparuk/\#2N-347 }\end{array}$ & same as Alpine CD1-01 & $\begin{array}{l}\text { a) } 31,540 \mathrm{bbl} ; \mathrm{b}) \\
100 \mathrm{bbl}\end{array}$ & & $\begin{array}{l}\text { same as Kuparuk } \\
\# 1 C-11\end{array}$ & & & $\begin{array}{l}\text { same as Alpine CD1- } \\
01\end{array}$ \\
\hline $\begin{array}{l}\text { Alaska/North } \\
\text { Slope/Kuparuk/\#2P-415A }\end{array}$ & same as Alpine CD1-01 & $31,333 \mathrm{bbl}$ & & & & & $\begin{array}{l}\text { same as Alpine CD1- } \\
01\end{array}$ \\
\hline $\begin{array}{l}\text { Alaska/North } \\
\text { Slope/Kuparuk/\#2P-417 }\end{array}$ & same as Alpine CD1-01 & $31,952 \mathrm{bbl}$ & & & & & $\begin{array}{l}\text { same as Alpine CD1- } \\
01\end{array}$ \\
\hline $\begin{array}{l}\text { Alaska/North } \\
\text { Slope/Kuparuk/\#2P-420 }\end{array}$ & same as Alpine CD1-01 & $9,729 \mathrm{bbl}$ & & & & & $\begin{array}{l}\text { same as Alpine CD1- } \\
01\end{array}$ \\
\hline $\begin{array}{l}\text { Alaska/North } \\
\text { Slope/Kuparuk/\#2P-438 }\end{array}$ & same as Alpine CD1-01 & $30,643 \mathrm{bbl}$ & & & & & $\begin{array}{l}\text { same as Alpine CD1- } \\
01\end{array}$ \\
\hline $\begin{array}{l}\text { Alaska/North } \\
\text { Slope/Kuparuk/\#2T-21 }\end{array}$ & same as Alpine CD1-01 & $91,369 \mathrm{bbl}$ & & & & & $\begin{array}{l}\text { same as Alpine CD1- } \\
01\end{array}$ \\
\hline $\begin{array}{l}\text { Alaska/North } \\
\text { Slope/Kuparuk/\#2T-32 }\end{array}$ & same as Alpine CD1-01 & $111,000 \mathrm{bbl}$ & & & & & $\begin{array}{l}\text { same as Alpine CD1- } \\
01\end{array}$ \\
\hline $\begin{array}{l}\text { Alaska/North } \\
\text { Slope/Kuparuk/\#2X-17 }\end{array}$ & same as Alpine CD1-01 & $495 \mathrm{bbl}$ & & & & & $\begin{array}{l}\text { same as Alpine CD1- } \\
01\end{array}$ \\
\hline \begin{tabular}{|l|} 
Alaska/North \\
Slope/Kuparuk/\#2X-18
\end{tabular} & same as Alpine CD1-01 & $25,079 \mathrm{bbl}$ & & & & & $\begin{array}{l}\text { same as Alpine CD1- } \\
01\end{array}$ \\
\hline $\begin{array}{l}\text { Alaska/North } \\
\text { Slope/Kuparuk/\#2Z-22 }\end{array}$ & same as Alpine CD1-01 & $10,807 \mathrm{bbl}$ & & & & & $\begin{array}{l}\text { same as Alpine CD1- } \\
01\end{array}$ \\
\hline $\begin{array}{l}\text { Alaska/North } \\
\text { Slope/Kuparuk/\#3A-17 }\end{array}$ & same as Alpine CD1-01 & $13,320 \mathrm{bbl}$ & & & & & $\begin{array}{l}\text { same as Alpine CD1- } \\
01\end{array}$ \\
\hline $\begin{array}{l}\text { Alaska/North } \\
\text { Slope/Kuparuk/\#3F-19 }\end{array}$ & same as Alpine CD1-01 & $15,394 \mathrm{bbl}$ & & & & & $\begin{array}{l}\text { same as Alpine CD1- } \\
01\end{array}$ \\
\hline
\end{tabular}




\begin{tabular}{|c|c|c|c|c|c|c|c|c|c|c|c|c|}
\hline Site Location/Name & $\begin{array}{l}\text { Operator } \\
\text { Generating } \\
\text { Wastes } \\
\end{array}$ & Source of Information & $\begin{array}{l}\text { Service } \\
\text { Company } \\
\text { Doing } \\
\text { Injection } \\
\end{array}$ & $\begin{array}{l}\text { Geology of Injection } \\
\text { Zone (type of rock, } \\
\text { porosity, permeability) }\end{array}$ & $\begin{array}{l}\text { Depth of } \\
\text { Injection Zone }\end{array}$ & $\begin{array}{l}\text { Depth of } \\
\text { Perforations/ } \\
\text { annular } \\
\text { Injection }\end{array}$ & $\begin{array}{l}\text { Geology and } \\
\text { Depth of } \\
\text { Confining } \\
\text { Layer } \\
\end{array}$ & $\begin{array}{l}\text { Other } \\
\text { Geological } \\
\text { Information }\end{array}$ & $\begin{array}{l}\text { Dates and Duration } \\
\text { of Injection }\end{array}$ & Injection Rate & $\begin{array}{l}\text { Injection } \\
\text { Pressure }\end{array}$ & $\begin{array}{l}\text { Type of } \\
\text { Injection }\end{array}$ \\
\hline \begin{tabular}{|l}
$\begin{array}{l}\text { Alaska/North } \\
\text { Slope/Kuparuk/\#3G-03 }\end{array}$ \\
\end{tabular} & Phillips Alaska & Regg \& Maunder (2003) & & & & & & & & & & annular \\
\hline \begin{tabular}{|l|} 
Alaska/North \\
Slope/Kuparuk/\#3H-24
\end{tabular} & Phillips Alaska & Regg \& Maunder (2003) & & & & & & & & & & annular \\
\hline $\begin{array}{l}\text { Alaska/North } \\
\text { Slope/Kuparuk/\#3J-19 }\end{array}$ & Phillips Alaska & Regg \& Maunder (2003) & & & & & & & & & & annular \\
\hline $\begin{array}{l}\text { Alaska/North } \\
\text { Slope/Kuparuk/\#3K-25 }\end{array}$ & Phillips Alaska & Regg \& Maunder (2003) & & & & & & & & & & annular \\
\hline $\begin{array}{l}\text { Alaska/North } \\
\text { Slope/Kuparuk/\#3K-26 }\end{array}$ & Phillips Alaska & Regg \& Maunder (2003) & & & & & & & & & & annular \\
\hline $\begin{array}{l}\text { Alaska/North } \\
\text { Slope/Kuparuk/\#3K-27 }\end{array}$ & Phillips Alaska & Regg \& Maunder (2003) & & & & & & & & & & annular \\
\hline $\begin{array}{l}\text { Alaska/North } \\
\text { Slope/Kuparuk/\#3K-32 }\end{array}$ & Phillips Alaska & Regg \& Maunder (2003) & & & & & & & & & & annular \\
\hline \begin{tabular}{|l|} 
Alaska/North \\
Slope/Kuparuk/\#3M-27
\end{tabular} & Phillips Alaska & Regg \& Maunder (2003) & & & & & & & & & & annular \\
\hline \begin{tabular}{|l|} 
Alaska/North \\
Slope/Kuparuk/\#3O-20
\end{tabular} & Phillips Alaska & Regg \& Maunder (2003) & & & & & & & & & & annular \\
\hline $\begin{array}{l}\text { Alaska/North } \\
\text { Slope/Kuparuk/\#3Q-22 }\end{array}$ & Phillips Alaska & Regg \& Maunder (2003) & & & & & & & & & & annular \\
\hline \begin{tabular}{|l|} 
Alaska/North \\
Slope/Kuparuk/\#3S-07
\end{tabular} & Phillips Alaska & Regg \& Maunder (2003) & & & & & & & & & & annular \\
\hline \begin{tabular}{|l|}
$\begin{array}{l}\text { Alaska/North } \\
\text { Slope/Kuparuk/\#3S-18 }\end{array}$ \\
\end{tabular} & Phillips Alaska & Regg \& Maunder (2003) & & & & & & & & & & annular \\
\hline $\begin{array}{l}\text { Alaska/North } \\
\text { Slope/Northstar/NS-10 }\end{array}$ & BPXA & $\begin{array}{l}\text { Syed and Cutler (2001); } \\
\text { Regg \& Maunder (2003) }\end{array}$ & & $\begin{array}{l}\text { upper injection zone is } \\
\text { Upper Brookian age } \\
\text { (sandstone and shale), } \\
\text { porosity } 29-34 \% \text {, } \\
\text { permeability } 250-4,500 \\
\text { md; lower injection zone is } \\
\text { Schrader Bluff formation, } \\
\text { porosity } 26-32 \% \text {, } \\
\text { permeability } 150-2,500 \mathrm{md}\end{array}$ & $\begin{array}{l}\text { upper - } 5,0077^{\prime}- \\
5,741^{\prime} ; \text { lower } \\
6,140^{\prime}-8,246^{\prime}\end{array}$ & $\begin{array}{l}\text { open hole 8,029'- } \\
8,246^{\prime}\end{array}$ & & $\begin{array}{l}\text { base of } \\
\text { permafrost is at } \\
1,512^{\prime}\end{array}$ & $\begin{array}{l}\text { well completed 1/01; } \\
\text { injection is ongoing } \\
\text { as of } 1 / 03\end{array}$ & & $\begin{array}{l}3,000 \text { psig } \\
\text { max. } \\
\text { allowable } \\
\text { pressure }\end{array}$ & $\begin{array}{l}\text { tubing and } \\
\text { packer }\end{array}$ \\
\hline $\begin{array}{l}\text { Alaska/North Slope/Pad } 3 \\
\text { NW }\end{array}$ & BPXA & $\begin{array}{l}\text { Syed and Cutler (2001); } \\
\text { Regg \& Maunder (2003) }\end{array}$ & & Sagavanirktok formation & $\begin{array}{l}\text { near surface to } \\
\sim 4,000^{\prime} ; \\
\text { permafrost } \\
\text { extends to } 1,835^{\prime}\end{array}$ & $\begin{array}{l}1,980^{\prime}-2,005^{\prime} \\
2,032^{\prime}-2,062 \\
2,073^{\prime}-2,093^{\prime}\end{array}$ & $\begin{array}{l}\text { interbedded } \\
\text { sands, silts, and } \\
\text { shaly } \\
\text { mudstones; } \\
\text { extends from } \\
\text { surface to } 132^{\prime}\end{array}$ & $\begin{array}{l}\text { injection zone } \\
\text { underlain by } \\
\text { approx. 2,000' of } \\
\text { interbedded } \\
\text { sands and } \\
\text { shales in the } \\
\text { Ugnu and West } \\
\text { Sak formations } \\
\end{array}$ & $\begin{array}{l}\text { first placed in service } \\
\text { in } 1 / 76 ; \text { completed } \\
\text { with tubing } 1 / 85 ; \\
\text { ongoing as of } 1 / 03\end{array}$ & $\begin{array}{l}3,500 \text { to } 4,000 \\
\text { bbl/day } \\
\text { maximum }\end{array}$ & $\begin{array}{l}900 \text { to } 1,100 \\
\text { psi } \\
\text { wellhead } \\
\text { pressure }\end{array}$ & $\begin{array}{l}\text { tubing and } \\
\text { packer }\end{array}$ \\
\hline $\begin{array}{l}\text { Alaska/North Slope/Pad } 3 \\
\text { SE }\end{array}$ & BPXA & $\begin{array}{l}\text { Syed and Cutler (2001); } \\
\text { Regg \& Maunder (2003) }\end{array}$ & & same as Pad $3 \mathrm{NW}$ & $\begin{array}{l}\text { same as Pad } 3 \\
\text { NW }\end{array}$ & $1,978^{\prime}-2,003^{\prime}$ & $\begin{array}{l}\text { same as Pad } 3 \\
\text { NW }\end{array}$ & $\begin{array}{l}\text { same as Pad } 3 \\
\text { NW }\end{array}$ & $\begin{array}{l}\text { first placed in service } \\
\text { in } 3 / 78 ; \text { completed } \\
\text { with tubing } 4 / 85 ; \\
\text { ongoing as of } 1 / 03\end{array}$ & $\begin{array}{l}\text { same as Pad } 3 \\
\text { NW }\end{array}$ & $\begin{array}{l}\text { same as } \\
\text { Pad } 3 \text { NW }\end{array}$ & $\begin{array}{l}\text { tubing and } \\
\text { packer }\end{array}$ \\
\hline $\begin{array}{l}\text { Alaska/North Slope/Pad } 3 \\
\text { SW }\end{array}$ & BPXA & $\begin{array}{l}\text { Syed and Cutler (2001); } \\
\text { Regg \& Maunder (2003) }\end{array}$ & & same as Pad 3 NW & $\begin{array}{l}\text { same as Pad } 3 \\
\text { NW }\end{array}$ & $1,980^{\prime}-2,005^{\prime}$ & $\begin{array}{l}\text { same as Pad } 3 \\
\text { NW }\end{array}$ & $\begin{array}{l}\text { same as Pad } 3 \\
\text { NW }\end{array}$ & $\begin{array}{l}\text { first placed in service } \\
\text { in } 1 / 85 \text {; ongoing as of } \\
1 / 03\end{array}$ & $\begin{array}{l}\text { f same as Pad } 3 \\
\text { NW }\end{array}$ & $\begin{array}{l}\text { same as } \\
\text { Pad } 3 \text { NW }\end{array}$ & $\begin{array}{l}\text { tubing and } \\
\text { packer }\end{array}$ \\
\hline
\end{tabular}




\begin{tabular}{|c|c|c|c|c|c|c|c|}
\hline Site Location/Name & Type of Waste Injected & $\begin{array}{l}\text { Volume of } \\
\text { Material } \\
\text { Injected } \\
\end{array}$ & $\begin{array}{l}\text { Slurry } \\
\text { Properties } \\
\text { (fluid, } \\
\text { density) } \\
\end{array}$ & $\begin{array}{l}\text { Pre-Injection } \\
\text { Processing/ } \\
\text { Treatment }\end{array}$ & Problems Experienced & Costs & Other Comments \\
\hline $\begin{array}{l}\text { Alaska/North } \\
\text { Slope/Kuparuk/\#3G-03 }\end{array}$ & same as Alpine CD1-01 & $6,473 \mathrm{bbl}$ & & & & & $\begin{array}{l}\text { same as Alpine CD1- } \\
01\end{array}$ \\
\hline $\begin{array}{l}\text { Alaska/North } \\
\text { Slope/Kuparuk/\#3H-24 }\end{array}$ & same as Alpine CD1-01 & $27,117 \mathrm{bbl}$ & & & & & $\begin{array}{l}\text { same as Alpine CD1- } \\
01\end{array}$ \\
\hline $\begin{array}{l}\text { Alaska/North } \\
\text { Slope/Kuparuk/\#3J-19 }\end{array}$ & same as Alpine CD1-01 & $21,235 \mathrm{bbl}$ & & & & & $\begin{array}{l}\text { same as Alpine CD1- } \\
01\end{array}$ \\
\hline $\begin{array}{l}\text { Alaska/North } \\
\text { Slope/Kuparuk/\#3K-25 }\end{array}$ & same as Alpine CD1-01 & $4,302 \mathrm{bbl}$ & & & & & $\begin{array}{l}\text { same as Alpine CD1- } \\
01\end{array}$ \\
\hline $\begin{array}{l}\text { Alaska/North } \\
\text { Slope/Kuparuk/\#3K-26 }\end{array}$ & same as Alpine CD1-01 & $34,070 \mathrm{bbl}$ & & & & & $\begin{array}{l}\text { same as Alpine CD1- } \\
01\end{array}$ \\
\hline $\begin{array}{l}\text { Alaska/North } \\
\text { Slope/Kuparuk/\#3K-27 }\end{array}$ & same as Alpine CD1-01 & $37,273 \mathrm{bbl}$ & & & & & $\begin{array}{l}\text { same as Alpine CD1- } \\
01\end{array}$ \\
\hline $\begin{array}{l}\text { Alaska/North } \\
\text { Slope/Kuparuk/\#3K-32 }\end{array}$ & same as Alpine CD1-01 & $33,480 \mathrm{bbl}$ & & & & & $\begin{array}{l}\text { same as Alpine CD1- } \\
01\end{array}$ \\
\hline $\begin{array}{l}\text { Alaska/North } \\
\text { Slope/Kuparuk/\#3M-27 }\end{array}$ & same as Alpine CD1-01 & $15,428 \mathrm{bbl}$ & & & & & $\begin{array}{l}\text { same as Alpine CD1- } \\
01\end{array}$ \\
\hline $\begin{array}{l}\text { Alaska/North } \\
\text { Slope/Kuparuk/\#3O-20 }\end{array}$ & same as Alpine CD1-01 & $11,905 \mathrm{bbl}$ & & & & & $\begin{array}{l}\text { same as Alpine CD1- } \\
01\end{array}$ \\
\hline $\begin{array}{l}\text { Alaska/North } \\
\text { Slope/Kuparuk/\#3Q-22 }\end{array}$ & same as Alpine CD1-01 & $6,345 \mathrm{bbl}$ & & & & & $\begin{array}{l}\text { same as Alpine CD1- } \\
01\end{array}$ \\
\hline $\begin{array}{l}\text { Alaska/North } \\
\text { Slope/Kuparuk/\#3S-07 }\end{array}$ & same as Alpine CD1-01 & $18,471 \mathrm{bbl}$ & & & & & $\begin{array}{l}\text { same as Alpine CD1- } \\
01\end{array}$ \\
\hline $\begin{array}{l}\text { Alaska/North } \\
\text { Slope/Kuparuk/\#3S-18 }\end{array}$ & same as Alpine CD1-01 & $306 \mathrm{bbl}$ & & & & & $\begin{array}{l}\text { same as Alpine CD1- } \\
01\end{array}$ \\
\hline $\begin{array}{l}\text { Alaska/North } \\
\text { Slope/Northstar/NS-10 }\end{array}$ & $\begin{array}{l}\text { all nonhazardous liquid } \\
\text { and solid wastes from } \\
\text { Northstar platform }\end{array}$ & $\begin{array}{l}1,307,229 \mathrm{bbl} \\
\text { through } 1 / 03\end{array}$ & & & & & $\begin{array}{l}\text { permitted as a Class } \\
\text { I nonhazardous well; }\end{array}$ \\
\hline $\begin{array}{l}\text { Alaska/North Slope/Pad } 3 \\
\text { NW }\end{array}$ & $\begin{array}{l}\text { seawater and brine, fresh } \\
\text { water, drilling mud, gel, } \\
\text { crude oil, produced water } \\
\text { stimulation fluids, cement } \\
\text { contaminate, diesel, } \\
\text { contaminated snow, } \\
\text { methanol, line pigging } \\
\text { materials, boiler water }\end{array}$ & $\begin{array}{l}6,283,038 \mathrm{bbl} \\
\text { through } 1 / 03\end{array}$ & & & & & $\begin{array}{l}\text { permitted as a Class } \\
\text { I nonhazardous well }\end{array}$ \\
\hline $\begin{array}{l}\text { Alaska/North Slope/Pad } 3 \\
\text { SE }\end{array}$ & same as Pad 3 NW & $\begin{array}{l}1,803,817 \mathrm{bbl} \\
\text { through } 1 / 03\end{array}$ & & & & & same as Pad 3 NW \\
\hline $\begin{array}{l}\text { Alaska/North Slope/Pad } 3 \\
\text { SW }\end{array}$ & same as Pad $3 \mathrm{NW}$ & $\begin{array}{l}5,478,335 \mathrm{bbl} \\
\text { through } 1 / 03\end{array}$ & & & & & same as Pad 3 NW \\
\hline
\end{tabular}




\begin{tabular}{|c|c|c|c|c|c|c|c|c|c|c|c|c|}
\hline Site Location/Name & $\begin{array}{l}\text { Operator } \\
\text { Generating } \\
\text { Wastes } \\
\end{array}$ & Source of Information & $\begin{array}{l}\text { Service } \\
\text { Company } \\
\text { Doing } \\
\text { Injection } \\
\end{array}$ & $\begin{array}{l}\text { Geology of Injection } \\
\text { Zone (type of rock, } \\
\text { porosity, permeability) }\end{array}$ & $\begin{array}{l}\text { Depth of } \\
\text { Injection Zone }\end{array}$ & $\begin{array}{l}\text { Depth of } \\
\text { Perforations/ } \\
\text { annular } \\
\text { Injection } \\
\end{array}$ & $\begin{array}{l}\text { Geology and } \\
\text { Depth of } \\
\text { Confining } \\
\text { Layer } \\
\end{array}$ & $\begin{array}{l}\text { Other } \\
\text { Geological } \\
\text { Information }\end{array}$ & $\begin{array}{l}\text { Dates and Duration } \\
\text { of Injection }\end{array}$ & Injection Rate & $\begin{array}{l}\text { Injection } \\
\text { Pressure }\end{array}$ & $\begin{array}{l}\text { Type of } \\
\text { Injection }\end{array}$ \\
\hline $\begin{array}{l}\text { Alaska/North Slope/Prudhoe } \\
\text { Bay/DS 4-19 (Grind and } \\
\text { Inject project) }\end{array}$ & Arco & $\begin{array}{l}\text { Schmidt et al. (1999); Regg } \\
\text { \& Maunder (2003) }\end{array}$ & & $\begin{array}{l}\text { Lower Tertiary Ugnu } \\
\text { formation - mixed sands } \\
\text { and shales; porosity: } 20- \\
42 \%\end{array}$ & & $5,930^{\prime}-6,598^{\prime}$ & & & $\begin{array}{l} \\
4 / 95-5 / 95 ; 12 / 95- \\
5 / 96 ; 12 / 96-3 / 97\end{array}$ & \begin{tabular}{|l|} 
\\
\\
\\
\\
average for 3 \\
injection periods \\
ranged from \\
$16.7-22$ bbl/min; \\
maximum rate - \\
44 bbl/min \\
\end{tabular} & \begin{tabular}{|l|} 
average \\
surface \\
pressure for \\
3 injection \\
periods \\
ranged from \\
$1,195-1,702$ \\
psi; \\
maximum \\
2,622 psi; \\
average \\
BHP for 3 \\
injection \\
periods \\
ranged from \\
$3,636-4,013$ \\
$;$ psi; \\
maximum \\
5,431 psi \\
\end{tabular} & $\begin{array}{l}\text { dedicated } \\
\text { injection } \\
\text { well; } \\
\text { converted } \\
\text { from water } \\
\text { disposal } \\
\text { well; } \\
\text { operator } \\
\text { squeezed } \\
70 \text { ' of } \\
\text { cement to } \\
\text { seal zone of } \\
\text { poor } \\
\text { bonding } \\
\end{array}$ \\
\hline $\begin{array}{l}\text { Alaska/North Slope/Prudhoe } \\
\text { Bay/G\&l } 1\end{array}$ & $B P$ & Regg \& Maunder (2003) & & & & & & & 4/98 - ongoing & & & \\
\hline $\begin{array}{l}\text { Alaska/North Slope/Prudhoe } \\
\text { Bay/G\&l } 2\end{array}$ & BP & Regg \& Maunder (2003) & & & & & & & 5/98 - ongoing & & & \\
\hline $\begin{array}{l}\text { Alaska/North Slope/Prudhoe } \\
\text { Bay/G\&l } 3\end{array}$ & $\mathrm{BP}$ & Regg \& Maunder (2003) & & & & & & & 3/98 - ongoing & & & \\
\hline $\begin{array}{l}\text { Alaska/North Slope/Prudhoe } \\
\text { Bay/CC-02A }\end{array}$ & Arco & Regg \& Maunder (2003) & & & & & & & $7 / 90-6 / 99$ & & & \\
\hline Argentina/Acumbuco Field $\mathrm{F}$ & Pan American & MI/SWACO (2002) & MI/SWACO & & & & & & $10 / 01-11 / 01$ & & & annular \\
\hline California/D-5, ST-2 & Unocal & Apollo Services (2002) & $\begin{array}{l}\text { Apollo } \\
\text { Services }\end{array}$ & & & $4,420^{\prime}$ & & & $12 / 2 / 99-1 / 23 / 00$ & $1.5-3.0 \mathrm{bbl} / \mathrm{min}$ & $\begin{array}{l}1,100-1,700 \\
\text { psi }\end{array}$ & annular \\
\hline California/Harmony/HA-22 & ExxonMobil & Apollo Services (2002) & $\begin{array}{l}\text { Apollo } \\
\text { Services }\end{array}$ & & & $5,200^{\prime}$ & & & $4 / 7 / 00-9 / 12 / 00$ & 2.0-3.1 bbl/min & $\begin{array}{l}1,000-1,350 \\
\text { psi }\end{array}$ & annular \\
\hline California/Harmony/HA-27 & ExxonMobil & Apollo Services (2002) & $\begin{array}{l}\text { Apollo } \\
\text { Services }\end{array}$ & & & $4,420^{\prime}$ & & & $10 / 1 / 00-1 / 11 / 00$ & $1.0-4.0 \mathrm{bbl} / \mathrm{min}$ & $\begin{array}{l}700-2,700 \\
\text { psi }\end{array}$ & annular \\
\hline $\begin{array}{l}\text { California/Heritage Platform/ } \\
\text { OCSG 193/\#HE-26 }\end{array}$ & E & Apollo Services (2002) & $\begin{array}{l}\text { Apollo } \\
\text { Services }\end{array}$ & & & & & & & & $\begin{array}{l}900-1770 \\
\text { psi }\end{array}$ & \\
\hline
\end{tabular}




\begin{tabular}{|c|c|c|c|c|c|c|c|}
\hline Site Location/Name & Type of Waste Injected & $\begin{array}{l}\text { Volume of } \\
\text { Material } \\
\text { Injected } \\
\end{array}$ & $\begin{array}{l}\text { Slurry } \\
\text { Properties } \\
\text { (fluid, } \\
\text { density) } \\
\end{array}$ & $\begin{array}{l}\text { Pre-Injection } \\
\text { Processing/ } \\
\text { Treatment }\end{array}$ & Problems Experienced & Costs & Other Comments \\
\hline $\begin{array}{l}\text { Alaska/North Slope/Prudhoe } \\
\text { Bay/DS 4-19 (Grind and } \\
\text { Inject project) }\end{array}$ & $\begin{array}{l}\text { frozen muds and cuttings } \\
\text { from numerous reserve } \\
\text { pits }\end{array}$ & $\begin{array}{l}\sim 87,000 \text { bbl pit } \\
\text { solids and } 7.6 \\
\text { million bbl total } \\
\text { slurry (Schmidt } \\
\text { et al. 1999); } 11 \\
\text { million bbl } \\
\text { drilling waste in } \\
50.3 \text { million bbl } \\
\text { of total slurry } \\
\text { (Regg \& } \\
\text { Maunder 2003) }\end{array}$ & & $\begin{array}{l}\text { pit contents were } \\
\text { thawed with } \\
\text { heated seawater } \\
\text { and the resulting } \\
\text { slurry was ground } \\
\text { in a ball mill }\end{array}$ & $\begin{array}{l}\text { on } 3 / 17 / 97 \text {, fluids began to } \\
\text { broach to the surface at } \\
\text { multiple locations near the } \\
\text { injection well; injection was } \\
\text { stopped and leaked fluids } \\
\text { were collected for disposal; } \\
\text { after } 4 \text { days and a total } \\
\text { volume of } 18,000 \text { bbl, flow } \\
\text { to the surface stopped; } \\
\text { several days later, low-rate } \\
\text { injection was started to } \\
\text { clean up the grind and inject } \\
\text { plant; no additional } \\
\text { broaching was observed; } \\
\text { the cause of the broaching } \\
\text { was believed to be } \\
\text { intersection of the injection } \\
\text { plume with other nearby } \\
\text { uncemented well bores that } \\
\text { lead to the surface. }\end{array}$ & & $\begin{array}{l}\text { in addition to } \\
\text { conventional } \\
\text { pressure, } \\
\text { temperature, and } \\
\text { rate monitoring, the } \\
\text { well was monitored } \\
\text { with microseismic } \\
\text { devices suspended } \\
\text { in a nearby well }\end{array}$ \\
\hline $\begin{array}{l}\text { Alaska/North Slope/Prudhoe } \\
\text { Bay/G\&l } 1\end{array}$ & $\begin{array}{l}\text { frozen muds and cuttings } \\
\text { from numerous reserve } \\
\text { pits }\end{array}$ & $15,683,000 \mathrm{bbl}$ & & $\begin{array}{l}\text { pit contents were } \\
\text { thawed with } \\
\text { heated seawater } \\
\text { and the resulting } \\
\text { slurry was ground } \\
\text { in a ball mill }\end{array}$ & & & $\begin{array}{l}\text { this is } 1 \text { of } 3 \text { new } \\
\text { wells created to } \\
\text { replace DS 4-19; } \\
\text { spaced } 300^{\prime} \text { apart at } \\
\text { surface and } 2,000^{\prime} \\
\text { apart at disposal } \\
\text { interval }\end{array}$ \\
\hline $\begin{array}{l}\text { Alaska/North Slope/Prudhoe } \\
\text { Bay/G\&l } 2\end{array}$ & $\begin{array}{l}\text { frozen muds and cuttings } \\
\text { from numerous reserve } \\
\text { pits }\end{array}$ & $15,802,000 \mathrm{bbl}$ & & $\begin{array}{l}\text { pit contents were } \\
\text { thawed with } \\
\text { heated seawater } \\
\text { and the resulting } \\
\text { slurry was ground } \\
\text { in a ball mill } \\
\end{array}$ & & & $\begin{array}{l}\text { this is } 1 \text { of } 3 \text { new } \\
\text { wells created to } \\
\text { replace DS 4-19; } \\
\text { spaced } 300^{\prime} \text { apart at } \\
\text { surface and 2,000' } \\
\text { apart at disposal } \\
\text { interval }\end{array}$ \\
\hline $\begin{array}{l}\text { Alaska/North Slope/Prudhoe } \\
\text { Bay/G\&l } 3\end{array}$ & $\begin{array}{l}\text { frozen muds and cuttings } \\
\text { from numerous reserve } \\
\text { pits }\end{array}$ & $12,075,000 \mathrm{bbl}$ & & $\begin{array}{l}\text { pit contents were } \\
\text { thawed with } \\
\text { heated seawater } \\
\text { and the resulting } \\
\text { slurry was ground } \\
\text { in a ball mill } \\
\end{array}$ & & & $\begin{array}{l}\text { this is } 1 \text { of } 3 \text { new } \\
\text { wells created to } \\
\text { replace DS 4-19; } \\
\text { spaced } 300^{\prime} \text { apart at } \\
\text { surface and 2,000' } \\
\text { apart at disposal } \\
\text { interval }\end{array}$ \\
\hline $\begin{array}{l}\text { Alaska/North Slope/Prudhoe } \\
\text { Bay/CC-02A }\end{array}$ & drilling waste & $>12$ million bbl & $\begin{array}{l}\text { stormwater } \\
\text { and fresh } \\
\text { water used as } \\
\text { liquid }\end{array}$ & processing mill & & & \\
\hline Argentina/Acumbuco Field & oil-based cuttings & $89,338 \mathrm{bbl}$ & & gel & & & $\begin{array}{l}\text { same as } \\
\text { Alaska/North } \\
\text { Slope/Alpine }\end{array}$ \\
\hline California/D-5, ST-2 & cuttings & 11,941 bbl slurry & $8.6-10.4 \mathrm{lb} / \mathrm{gal}$ & & & & $\begin{array}{l}\text { limited data provided } \\
\text { for this job }\end{array}$ \\
\hline California/Harmony/HA-22 & cuttings & 12,780 bbl slurry & $8.6-9.8 \mathrm{lb} / \mathrm{gal}$ & & & & $\begin{array}{l}\text { limited data provided } \\
\text { for this job }\end{array}$ \\
\hline California/Harmony/HA-27 & cuttings & 54,295 bbl slurry & $8.6-10.4 \mathrm{lb} / \mathrm{gal}$ & $\begin{array}{l}\text { Prologic } \\
\text { (viscosifer) }\end{array}$ & & & $\begin{array}{l}\text { limited data provided } \\
\text { for this job }\end{array}$ \\
\hline $\begin{array}{l}\text { California/Heritage Platform/ } \\
\text { OCSG 193/\#HE-26 }\end{array}$ & cuttings & $36,721 \mathrm{bbl}$ & $\begin{array}{l}8.6-11.3 \\
\mathrm{lb} / \mathrm{gal}\end{array}$ & $\begin{array}{l}\text { Prologic } \\
\text { (viscosifer) }\end{array}$ & & & $\begin{array}{l}\text { when not injecting, } \\
\text { slurry, need to inject } \\
\text { water every } 4-6 \\
\text { hours to maintain } \\
\text { hole integrity } \\
\end{array}$ \\
\hline
\end{tabular}




\begin{tabular}{|c|c|c|c|c|c|c|c|c|c|c|c|c|}
\hline Site Location/Name & $\begin{array}{l}\text { Operator } \\
\text { Generating } \\
\text { Wastes } \\
\end{array}$ & Source of Information & $\begin{array}{l}\text { Service } \\
\text { Company } \\
\text { Doing } \\
\text { Injection } \\
\end{array}$ & $\begin{array}{l}\text { Geology of Injection } \\
\text { Zone (type of rock, } \\
\text { porosity, permeability) }\end{array}$ & $\begin{array}{l}\text { Depth of } \\
\text { Injection Zone }\end{array}$ & $\begin{array}{l}\text { Depth of } \\
\text { Perforations/ } \\
\text { annular } \\
\text { Injection }\end{array}$ & $\begin{array}{l}\text { Geology and } \\
\text { Depth of } \\
\text { Confining } \\
\text { Layer } \\
\end{array}$ & $\begin{array}{l}\text { Other } \\
\text { Geological } \\
\text { Information }\end{array}$ & $\begin{array}{l}\text { Dates and Duration } \\
\text { of Injection }\end{array}$ & Injection Rate & $\begin{array}{l}\text { Injection } \\
\text { Pressure }\end{array}$ & $\begin{array}{l}\text { Type of } \\
\text { Injection }\end{array}$ \\
\hline $\begin{array}{l}\text { California/Heritage } \\
\text { Platform/OCSG 193/\#HE-2 }\end{array}$ & ExxonMobil & Apollo Services (2002) & $\begin{array}{l}\text { Apollo } \\
\text { Services }\end{array}$ & & & & & & $2 / 27 / 00-6 / 25 / 00$ & $1.5-3.2 \mathrm{bbl} / \mathrm{min}$ & $\begin{array}{l}790-1770 \\
\text { psi }\end{array}$ & annular \\
\hline $\begin{array}{l}\text { California/Heritage/HE-25, } \\
\text { ST-3 }\end{array}$ & ExxonMobil & Apollo Services (2002) & $\begin{array}{l}\text { Apollo } \\
\text { Services }\end{array}$ & & & $4,613^{\prime}$ & & & $2 / 26 / 02-3 / 20 / 02$ & $1.0-3.3 \mathrm{bbl} / \mathrm{min}$ & $\begin{array}{l}1,175-1,575 \\
\text { psi }\end{array}$ & annular \\
\hline California/Heritage/HE-30 & ExxonMobil & Apollo Services (2002) & $\begin{array}{l}\text { Apollo } \\
\text { Services }\end{array}$ & & & $5,415^{\prime}$ & & & 6/17/02 - 7/26/02 & $2.0-3.3 \mathrm{bbl} / \mathrm{min}$ & $\begin{array}{l}1,000-1,647 \\
\text { psi }\end{array}$ & annular \\
\hline California/Heritage/SA-1 & ExxonMobil & Apollo Services (2002) & $\begin{array}{l}\text { Apollo } \\
\text { Services }\end{array}$ & & & $4,320^{\prime}$ & & & $8 / 8 / 99-9 / 15 / 99$ & $1.1-3.3 \mathrm{bbl} / \mathrm{min}$ & $\begin{array}{l}800-1,700 \\
\text { psi }\end{array}$ & annular \\
\hline California/Heritage/SA-2 & ExxonMobil & Apollo Services (2002) & $\begin{array}{l}\text { Apollo } \\
\text { Services }\end{array}$ & & & $4,537^{\prime}$ & & & $2 / 27 / 00-6 / 25 / 00$ & $1.5-3.2 \mathrm{bbl} / \mathrm{min}$ & $\begin{array}{l}\text { 680-1,750 } \\
\text { psi }\end{array}$ & annular \\
\hline California/Heritage/SA-3 & ExxonMobil & Apollo Services (2002) & $\begin{array}{l}\text { Apollo } \\
\text { Services }\end{array}$ & & & $4,613^{\prime}$ & & & $7 / 10 / 00-2 / 14 / 01$ & $1.3-3.3 \mathrm{bbl} / \mathrm{min}$ & $\begin{array}{l}\text { 600-1,550 } \\
\text { psi }\end{array}$ & annular \\
\hline California/Heritage/SA-5 & ExxonMobil & Apollo Services (2002) & $\begin{array}{l}\text { Apollo } \\
\text { Services }\end{array}$ & & & $4,513^{\prime}$ & & & $5 / 7 / 01-7 / 21 / 01$ & $1.0-3.6 \mathrm{bbl} / \mathrm{min}$ & $\begin{array}{l}900-1,481 \\
\text { psi }\end{array}$ & annular \\
\hline California/Heritage/SA-6 & ExxonMobil & Apollo Services (2002) & $\begin{array}{l}\text { Apollo } \\
\text { Services }\end{array}$ & & & $4,613^{\prime}$ & & & $8 / 24 / 02-9 / 28 / 02$ & $2.0-3.3 \mathrm{bbl} / \mathrm{min}$ & $\begin{array}{l}900-1,538 \\
\text { psi }\end{array}$ & annular \\
\hline California/Holly & Veneco & MI/SWACO (2002) & MI/SWACO & & & & & & $4 / 02-9 / 02$ & & & $\begin{array}{l}\text { dedicated } \\
\text { well, tubing } \\
\text { and packer }\end{array}$ \\
\hline California/Hondo/HO-22 & ExxonMobil & Apollo Services (2002) & $\begin{array}{l}\text { Apollo } \\
\text { Services }\end{array}$ & & & $5,200^{\prime}$ & & & $4 / 10 / 00-8 / 3 / 00$ & $2.0-2.6 \mathrm{bbl} / \mathrm{min}$ & $\begin{array}{l}700-1,600 \\
\text { psi }\end{array}$ & annular \\
\hline $\begin{array}{l}\text { California/Hondo/OCSG } \\
188 / \# \mathrm{HO}-13\end{array}$ & ExxonMobil & Apollo Services (2002) & $\begin{array}{l}\text { Apollo } \\
\text { Services }\end{array}$ & & & & & & $4 / 10 / 00-5 / 14 / 00$ & $2.0 \mathrm{bbl} / \mathrm{min}$ & $\begin{array}{l}940-1600 \\
\text { psi }\end{array}$ & annular \\
\hline $\begin{array}{l}\text { California/Hondo/OCSG } \\
\text { 188/\#HO-4 }\end{array}$ & ExxonMobil & Apollo Services (2002) & $\begin{array}{l}\text { Apollo } \\
\text { Services }\end{array}$ & & & & & & $5 / 14 / 00-8 / 3 / 00$ & $2.0-2.6 \mathrm{bbl} / \mathrm{min}$ & $\begin{array}{l}700-1350 \\
\text { psi }\end{array}$ & annular \\
\hline $\begin{array}{l}\text { California/Long } \\
\text { Beach/THUMS }\end{array}$ & $\begin{array}{l}\text { ARCO/ } \\
\text { THUMS Long } \\
\text { Beach } \\
\text { Company } \\
\end{array}$ & $\begin{array}{l}\text { Hainey et al. (1997, 1999); } \\
\text { Keck (1999, 2000); Terralog } \\
\text { (2001) }\end{array}$ & & $\begin{array}{l}\text { terminal sands (four large } \\
\text { multiple sand-shale } \\
\text { sequences); porosity: } 23- \\
26 \% \text {; permeability: } 220 \text { - } \\
280 \text { md }\end{array}$ & $4,600^{\prime}-5,300^{\prime}$ & \begin{tabular}{|l|} 
AA sands at \\
$4,670^{\prime}-4,680^{\prime} ; A B$ \\
sands at $4,710^{\prime}-$ \\
$4,810^{\prime} ;$ AC sands \\
at $4,842^{\prime}-4,985^{\prime} ;$ \\
AD sands at \\
$5,090^{\prime}-5,218^{\prime}$ \\
\end{tabular} & & $\begin{array}{l}\text { upper sand layer } \\
\text { (Ranger sands) } \\
\text { and its overlying } \\
\text { shale layer did } \\
\text { not offer enough } \\
\text { protection for } \\
\text { fracture } \\
\text { containment } \\
\end{array}$ & $\begin{array}{l}\text { began in } 1994 \text { and is } \\
\text { ongoing; injection } \\
\text { occurs for several } \\
\text { hours each day then } \\
\text { stops in the afternoon }\end{array}$ & $\begin{array}{l}2-6 \mathrm{bbl} / \mathrm{min} ; \\
220,000- \\
25,000 \\
\text { bbl/month }\end{array}$ & $\begin{array}{l}\text { 1,800-2,700 } \\
\text { psi (Hainey, } \\
\text { Keck); } \\
2,534-2,905 \\
\text { psi } \\
\text { (Terralog) }\end{array}$ & $\begin{array}{l}0 \\
\text { tubing and } \\
\text { packer }\end{array}$ \\
\hline $\begin{array}{l}\text { California/onshore/West } \\
\text { Coyote }\end{array}$ & Chevron & $\begin{array}{l}\text { Sipple-Srinivasan et al. } \\
\text { (1998); Terralog (2001, } \\
\text { 2002b); Dusseault and Bilak } \\
\text { (1998) }\end{array}$ & Terralog & $\begin{array}{l}\text { not specified; permeability: } \\
400 \mathrm{md} \text { near perfs and up } \\
\text { to } 1,000 \mathrm{md} \text { elsewhere in } \\
\text { the formation; porosity } \\
28 \%\end{array}$ & $3,900^{\prime}-4,237^{\prime}$ & $4,110^{\prime}-4,150^{\prime}$ & $\begin{array}{l}\text { shale barrier at } \\
\text { about } 3,900^{\prime}\end{array}$ & & $\begin{array}{l}8 / 97-9 / 97 \text { (18 } \\
\text { injection episodes) }\end{array}$ & $\begin{array}{l}10-12 \mathrm{bbl} / \mathrm{min} ; \\
\sim 2,500 \mathrm{bbl} / \mathrm{day}\end{array}$ & $\begin{array}{l}2,800- \\
3,300 \text { psi } \\
\text { bottom hole } \\
\text { pressure }\end{array}$ & $\begin{array}{l}\text { tubing and } \\
\text { packer }\end{array}$ \\
\hline Canada/Alberta/Bonnyville & Koch & $\begin{array}{l}\text { Terralog (2001, 2002b); } \\
\text { Dusseault and Bilak (1998) }\end{array}$ & Terralog & $\begin{array}{l}\text { Clearwater and } \\
\text { Lloydminster formations; } \\
\text { permeability: 1,000 md; } \\
\text { porosity: } 27-30 \% \\
\end{array}$ & $\begin{array}{l}\text { Clearwater: } \\
\text { 1,348'-1,542'; } \\
\text { Lloydminster: } \\
1,224^{\prime}-1,316^{\prime} \\
\end{array}$ & $\begin{array}{l}\text { Clearwater: } \\
\text { 1,440'-1,473'; } \\
\text { Lloydminster: } \\
\text { 1,265'-1,298' } \\
\end{array}$ & & & $3 / 97-11 / 97$ & $8-9 \mathrm{bbl} / \mathrm{min}$ & $\begin{array}{l}1,450-1,900 \\
\text { psi BHP }\end{array}$ & $\begin{array}{l}0 \text { tubing and } \\
\text { packer }\end{array}$ \\
\hline
\end{tabular}




\begin{tabular}{|c|c|c|c|c|c|c|c|}
\hline Site Location/Name & Type of Waste Injected & $\begin{array}{l}\text { Volume of } \\
\text { Material } \\
\text { Injected } \\
\end{array}$ & $\begin{array}{l}\text { Slurry } \\
\text { Properties } \\
\text { (fluid, } \\
\text { density) } \\
\end{array}$ & $\begin{array}{l}\text { Pre-Injection } \\
\text { Processing/ } \\
\text { Treatment }\end{array}$ & Problems Experienced & Costs & Other Comments \\
\hline $\begin{array}{l}\text { California/Heritage } \\
\text { Platform/OCSG 193/\#HE-21 }\end{array}$ & cuttings & $36,721 \mathrm{bbl}$ & $4.5-11.3 \mathrm{lb} / \mathrm{gal}$ & $\begin{array}{l}\text { Prologic } \\
\text { (viscosifer) }\end{array}$ & & & $\begin{array}{l}\text { when not injecting, } \\
\text { slurry, need to inject } \\
\text { water every } 4-6 \\
\text { hours to maintain } \\
\text { hole integrity }\end{array}$ \\
\hline $\begin{array}{l}\text { California/Heritage/HE-25, } \\
\text { ST-3 }\end{array}$ & cuttings & $16,771 \mathrm{bbl}$ slurry & $8.7-10.3 \mathrm{lb} / \mathrm{gal}$ & & & & $\begin{array}{l}\text { limited data provided } \\
\text { for this job }\end{array}$ \\
\hline California/Heritage/HE-30 & cuttings & 24,731 bbl slurry & $8.6-10.0 \mathrm{lb} / \mathrm{gal}$ & & & & $\begin{array}{l}\text { limited data provided } \\
\text { for this job }\end{array}$ \\
\hline California/Heritage/SA-1 & cuttings & $21,320 \mathrm{bbl}$ slurry & $8.4-10.1 \mathrm{lb} / \mathrm{gal}$ & & & & $\begin{array}{l}\text { limited data provided } \\
\text { for this job }\end{array}$ \\
\hline California/Heritage/SA-2 & cuttings & 39,015 bbl slurry & $8.6-11.3 \mathrm{lb} / \mathrm{gal}$ & & & & $\begin{array}{l}\text { limited data provided } \\
\text { for this job }\end{array}$ \\
\hline California/Heritage/SA-3 & cuttings & $15,251 \mathrm{bbl}$ slurry & $8.7-9.9 \mathrm{lb} / \mathrm{gal}$ & & & & $\begin{array}{l}\text { limited data provided } \\
\text { for this job }\end{array}$ \\
\hline California/Heritage/SA-5 & cuttings & 21,016 bbl slurry & $8.7-10.2 \mathrm{lb} / \mathrm{gal}$ & & & & $\begin{array}{l}\text { limited data provided } \\
\text { for this job }\end{array}$ \\
\hline California/Heritage/SA-6 & cuttings & $28,514 \mathrm{bbl}$ slurry & $8.5-9.8 \mathrm{lb} / \mathrm{gal}$ & & & & $\begin{array}{l}\text { limited data provided } \\
\text { for this job }\end{array}$ \\
\hline California/Holly & & $2,885 \mathrm{bbl}$ & & & & & $\begin{array}{l}\text { same as } \\
\text { Alaska/North } \\
\text { Slope/Alpine }\end{array}$ \\
\hline California/Hondo/HO-22 & cuttings & $31,640 \mathrm{bbl}$ slurry & $8.6-11.5 \mathrm{lb} / \mathrm{gal}$ & $\begin{array}{l}\text { Prologic } \\
\text { (viscosifer) }\end{array}$ & & & $\begin{array}{l}\text { limited data provided } \\
\text { for this job }\end{array}$ \\
\hline $\begin{array}{l}\text { California/Hondo/OCSG } \\
188 / \# \mathrm{HO}-13\end{array}$ & cuttings & $14,919 \mathrm{bbl}$ & $\begin{array}{l}8.7-10.5 \\
\text { lb/gal }\end{array}$ & $\begin{array}{l}\text { Prologic } \\
\text { (viscosifer) }\end{array}$ & & & $\begin{array}{l}\text { when not injecting, } \\
\text { slurry, need to inject } \\
\text { water every } 4-6 \\
\text { hours to maintain } \\
\text { hole integrity }\end{array}$ \\
\hline $\begin{array}{l}\text { California/Hondo/OCSG } \\
\text { 188/\#HO-4 }\end{array}$ & cuttings & $16,415 \mathrm{bbl}$ & $\begin{array}{l}8.6-11.5 \\
\mathrm{lb} / \mathrm{gal}\end{array}$ & $\begin{array}{l}\text { Prologic } \\
\text { (viscosifer) }\end{array}$ & & & $\begin{array}{l}\text { when not injecting, } \\
\text { slurry, need to inject } \\
\text { water every } 4-6 \\
\text { hours to maintain } \\
\text { hole integrity }\end{array}$ \\
\hline $\begin{array}{l}\text { California/Long } \\
\text { Beach/THUMS }\end{array}$ & $\begin{array}{l}\text { cuttings, tank bottoms, } \\
\text { and clay waste }\end{array}$ & $\begin{array}{l}1.6 \text { million bbl } \\
\text { slurry and } \\
34,000 \text { cu. yd } \\
\text { solids (Hainey, } \\
\text { Keck); } \sim 175,000 \\
\text { bbl cuttings, } \sim 1 \\
\text { million bbl clay } \\
\text { waste, } \sim 585,000 \\
\text { bbl tank } \\
\text { bottoms, } \\
\sim 230,000 \text { bbl } \\
\text { water through } \\
2001 \text { (Terralog) }\end{array}$ & $\begin{array}{l}\text { density: 8.3- } \\
11.2 \text { lb/gal; } \\
\text { viscosity: } 70- \\
90 \text { sec/qt; } \\
\text { solids content: } \\
\text { 18-25\%; water } \\
\text { used as fluid }\end{array}$ & $\begin{array}{l}\text { centrifugal pump } \\
\text { used to break } \\
\text { solids into smaller } \\
\text { particles; slurry is } \\
\text { circulated until } \\
\text { proper viscosity is } \\
\text { reached }\end{array}$ & $\begin{array}{l}\text { after about a year of } \\
\text { injection into AD sands, } \\
\text { increased pressure and flow } \\
\text { was discovered in another } \\
\text { well about } 1,600^{\prime} \text { away; } A D \\
\text { layer was abandoned and } \\
\text { injection began again in } \\
\text { next layer up (AC sand); } \\
\text { later, injection shifted to AB } \\
\text { sand }\end{array}$ & $\begin{array}{l}\text { injection saves } \\
\$ 450,000 / y r \text { over } \\
\text { landfill disposal; } \\
\text { assuming that a } \\
\text { recompletion of } \\
\text { the injection well } \\
\text { is needed each } \\
\text { year at } \$ 200,000, \\
\text { the net saving is } \\
\$ 250,000 / \mathrm{yr}\end{array}$ & \\
\hline $\begin{array}{l}\text { California/onshore/West } \\
\text { Coyote }\end{array}$ & $\begin{array}{l}\text { oil-contaminated soil; } \\
\text { waste mud }\end{array}$ & $\begin{array}{l}15,993 \mathrm{bbl} \\
\text { waste; } 50,408 \\
\text { bbl total slurry }\end{array}$ & solids $10-35 \%$ & & & $\begin{array}{l}\text { target cost of } \\
\$ 8 / \mathrm{bbl} ; \text { no data } \\
\text { provided on } \\
\text { actual cost }\end{array}$ & $\begin{array}{l}\text { listed in Terralog } \\
\text { (2002b) as project } \\
\text { TTI9; listed in } \\
\text { Dusseault and Bilak } \\
\text { (1998) as project } 4\end{array}$ \\
\hline Canada/Alberta/Bonnyville & oily produced sand & $\begin{array}{l}157,000 \mathrm{bbl} \\
\text { waste and } \\
400,000 \mathrm{bbl} \text { total } \\
\text { slurry }\end{array}$ & & & $\begin{array}{l}\text { over four months of injection } \\
\text { into the Clearwater } \\
\text { formation resulted in an } \\
\text { increase in injection } \\
\text { pressure; wellbore } \\
\text { complications required a } \\
\text { switch to the Lloydminster } \\
\text { formation }\end{array}$ & & $\begin{array}{l}\text { listed in Terralog } \\
\text { (2002b) as projects } \\
\text { TTI5 (Clearwater) } \\
\text { and TT17 } \\
\text { (Lloydminster); listed } \\
\text { in Dusseault and } \\
\text { Bilak (1998) as } \\
\text { project 1 }\end{array}$ \\
\hline
\end{tabular}




\begin{tabular}{|c|c|c|c|c|c|c|c|c|c|c|c|c|}
\hline Site Location/Name & $\begin{array}{l}\text { Operator } \\
\text { Generating } \\
\text { Wastes }\end{array}$ & Source of Information & \begin{tabular}{|l|} 
Service \\
Company \\
Doing \\
Injection \\
\end{tabular} & $\begin{array}{l}\text { Geology of Injection } \\
\text { Zone (type of rock, } \\
\text { porosity, permeability) }\end{array}$ & $\begin{array}{l}\text { Depth of } \\
\text { Injection Zone }\end{array}$ & $\begin{array}{l}\text { Depth of } \\
\text { Perforations/ } \\
\text { annular } \\
\text { Injection } \\
\end{array}$ & $\begin{array}{l}\text { Geology and } \\
\text { Depth of } \\
\text { Confining } \\
\text { Layer }\end{array}$ & $\begin{array}{l}\text { Other } \\
\text { Geological } \\
\text { Information }\end{array}$ & $\begin{array}{l}\text { Dates and Duration } \\
\text { of Injection }\end{array}$ & Injection Rate & $\begin{array}{l}\text { Injection } \\
\text { Pressure }\end{array}$ & $\begin{array}{l}\text { Type of } \\
\text { Injection }\end{array}$ \\
\hline Canada/Alberta/Lindbergh & Norcen & $\begin{array}{l}\text { Sipple-Srinivasan (1997); } \\
\text { Terralog }(2001,2002 b)\end{array}$ & Terralog & $\begin{array}{l}\text { Rex formation; } \\
\text { permeability: } 1,000 \mathrm{md} \text {; } \\
\text { porosity: } 27-30 \%\end{array}$ & & $1,955-1,981$ & & & $\begin{array}{l}72 \text { injection episodes } \\
\text { during } 9 / 96-11 / 96 \\
\text { and } 6 / 97-7 / 97\end{array}$ & $9-12 \mathrm{bbl} / \mathrm{min}$ & $\begin{array}{l}2,000-2,500 \\
\text { psi BHP }\end{array}$ & $\begin{array}{l}\text { tubing and } \\
\text { packer }\end{array}$ \\
\hline Canada/Alberta/Lindbergh & Elan & Terralog (2002b) & Terralog & $\begin{array}{l}\text { Clearwater formation: } \\
\text { permeability: 1,000 md; } \\
\text { porosity: } 27-30 \%\end{array}$ & $1,696^{\prime}-2,057^{\prime}$ & $1,955^{\prime}-1,985^{\prime}$ & & & $8 / 97-9 / 97$ & $1.8-11.3 \mathrm{bbl} / \mathrm{min}$ & $\begin{array}{l}740-2,075 \\
\mathrm{psi}\end{array}$ & $\begin{array}{l}\text { tubing and } \\
\text { packer }\end{array}$ \\
\hline Canada/Alberta/Wolf Lake & Amoco & Terralog $(2001,2002 \mathrm{~b})$ & Terralog & $\begin{array}{l}\text { Mannville formation; } \\
\text { permeability: } 209 \mathrm{md} ; \\
\text { porosity: } 27-30 \%\end{array}$ & $1,378^{\prime}-1,446^{\prime}$ & $1,386^{\prime}-1,446^{\prime}$ & & & $\begin{array}{l}38 \text { injection episodes } \\
\text { during 4/96 - } 6 / 96 \text { and } \\
\text { in 10/97 }\end{array}$ & $9-12 \mathrm{bbl} / \mathrm{min}$ & $\begin{array}{l}1,600-1,800 \\
\text { psi BHP }\end{array}$ & $\begin{array}{l}\text { tubing and } \\
\text { packer }\end{array}$ \\
\hline $\begin{array}{l}\text { Canada/Nova } \\
\text { Scotia/Panuke P1-1 }\end{array}$ & PanCanadian & Guo et al. (2000) & & sandstone layer & -3,800'-4,500' & $4,245^{\prime}-4,265^{\prime}$ & \begin{tabular}{|l|} 
Petrel \\
limestone, \\
Logan Canyon \\
sandy-shale \\
from $3,800^{\prime}-$ \\
$4,200^{\prime}$; Petrel \\
Limestone from \\
$3,700^{\prime}-3,800^{\prime}$ \\
\end{tabular} & $\begin{array}{l}\text { layers nearer } \\
\text { surface } \\
\text { described for } \\
\text { well PP3C } \\
\end{array}$ & $\begin{array}{l}\text { not specified, but } \\
\text { before early } 1999\end{array}$ & not specified & $\begin{array}{l}\text { not } \\
\text { specified }\end{array}$ & $\begin{array}{l}\text { tubing and } \\
\text { packer }\end{array}$ \\
\hline $\begin{array}{l}\text { Canada/Nova } \\
\text { Scotia/Panuke PP3C }\end{array}$ & PanCanadian & Guo et al. (2000) & & $\begin{array}{l}\text { Dawson Canyon sandy } \\
\text { shale formation }\end{array}$ & below 3,500' & \begin{tabular}{l|} 
injection is into \\
the $11-3 / 4 "$ by $9^{\prime \prime}$ \\
annulus; $11-3 / 4^{\prime \prime}$ \\
casing shoe is \\
set at $\sim 3,500^{\prime}$ \\
\end{tabular} & $\begin{array}{l}\text { Wyandott Chalk } \\
\text { from } 2,900^{\prime}- \\
3,500^{\prime} \text {; shale } \\
\text { layer from } 2,000^{\prime} \\
2,900^{\prime} ; \text { nearly } \\
2,000^{\prime} \text { of sand } \\
\text { and sandy shale } \\
\text { to surface }\end{array}$ & $\begin{array}{l}\text { Dawson Canyon } \\
\text { formation } \\
\text { underlain by } \\
\text { Petrel limestone, } \\
\text { Logan Canyon } \\
\text { sandy-shale, and } \\
\text { a thick sand layer }\end{array}$ & $\begin{array}{l}\text { 9/16/99 - 10/18/99; } \\
\text { slurry injected in } \\
\text { batches of } 19-31 \text { bbl; } \\
\text { if slurry was not } \\
\text { available for more } \\
\text { than } 3 \text { hours, } \\
\text { seawater was } \\
\text { injected }\end{array}$ & $1.9-3.1 \mathrm{bbl} / \mathrm{min}$ & $\begin{array}{l}\text { not } \\
\text { specified }\end{array}$ & annular \\
\hline Canada/Saskatchewan & Mobil & Dusseault and Bilak (1997) & & $\begin{array}{l}\text { quartzose sandstone; } \\
\text { porosity: } 30 \%\end{array}$ & & $\sim 2,260^{\prime}$ & & & $1998-1990$ & & & \\
\hline $\begin{array}{l}\text { Canada/Saskatchewan/ } \\
\text { Edam }\end{array}$ & Wascana & $\begin{array}{l}\text { Sipple-Srinivasan } \\
\text { (1997);Terralog (2001; } \\
\text { 2002b); Dusseault and Bilak } \\
\text { (1998) }\end{array}$ & Terralog & $\begin{array}{l}\text { Dina formation; massive } \\
\text { sands; permeability: } 3,000 \\
\text { md; porosity: } 27-30 \%\end{array}$ & $1,811^{\prime}-1,975^{\prime}$ & 1,880'-1942' & & & $\begin{array}{l}101 \text { injection } \\
\text { episodes between } \\
1 / 97-6 / 97\end{array}$ & $9-12 \mathrm{bbl} / \mathrm{min}$ & $\begin{array}{l}1,450-1,750 \\
\text { psi BHP }\end{array}$ & $\begin{array}{l}\text { tubing and } \\
\text { packer }\end{array}$ \\
\hline $\begin{array}{l}\text { Canada/Saskatchewan/ } \\
\text { Edam }\end{array}$ & Anderson & $\begin{array}{l}\text { Terralog }(2001,2002 b) ; \\
\text { Dusseault and Bilak (1998) }\end{array}$ & Terralog & $\begin{array}{l}\text { Dina formation; massive } \\
\text { sands; permeability: } 1,800 \\
\text { md; porosity: } 27-30 \%\end{array}$ & $1,847^{\prime}-2,051^{\prime}$ & $1,942^{\prime}-1,975^{\prime}$ & & & $\begin{array}{l}132 \text { injection } \\
\text { episodes between } \\
5 / 97-10 / 97\end{array}$ & $9-12 \mathrm{bbl} / \mathrm{min}$ & $\begin{array}{l}1,900-2,350 \\
\text { psi BHP }\end{array}$ & $\begin{array}{l}\text { tubing and } \\
\text { packer }\end{array}$ \\
\hline Chad/M-501 & Esso & Apollo Services (2002) & $\begin{array}{l}\text { Apollo } \\
\text { Services }\end{array}$ & & & $5,916^{\prime}$ & & & $3 / 6 / 02-12 / 3 / 02$ & $3.7 \mathrm{bbl} / \mathrm{min}$ & $900 \mathrm{psi}$ & annular \\
\hline $\begin{array}{l}\text { Egypt/Gulf of } \\
\text { Suez/Ramadan 6-55 }\end{array}$ & GUPCO & Holt et al. (1995) & & $\begin{array}{l}\text { formation not specified; } \\
\text { fracture modeling } \\
\text { assumed } 5 \% \text { porosity and } \\
0.005 \mathrm{md} \text { permeability }\end{array}$ & not specified & $\begin{array}{l}\text { injection is into } \\
\text { the } 13-3 / 8 " \text { × } 9- \\
5 / 8 " \text { annulus }\end{array}$ & & & $\begin{array}{l}\text { not specified; } \\
\text { believed to be during } \\
1994\end{array}$ & $2 \mathrm{bbl} / \mathrm{min}$ & $\begin{array}{l}1,600 \mathrm{psi} \\
\text { average }\end{array}$ & annular \\
\hline
\end{tabular}




\begin{tabular}{|c|c|c|c|c|c|c|c|}
\hline Site Location/Name & Type of Waste Injected & $\begin{array}{l}\text { Volume of } \\
\text { Material } \\
\text { Injected } \\
\end{array}$ & $\begin{array}{l}\text { Slurry } \\
\text { Properties } \\
\text { (fluid, } \\
\text { density) } \\
\end{array}$ & $\begin{array}{l}\text { Pre-Injection } \\
\text { Processing/ } \\
\text { Treatment }\end{array}$ & Problems Experienced & Costs & Other Comments \\
\hline Canada/Alberta/Lindbergh & oily produced sand & $\begin{array}{l}80,000 \mathrm{bbl} \text { sand } \\
\text { and } 347,000 \mathrm{bbl} \\
\text { total slurry }\end{array}$ & & & & & $\begin{array}{l}\text { listed in Terralog } \\
\text { (2002b) as project } \\
\text { TTI3; listed in Sipple- } \\
\text { Srinivasan (1997) as } \\
\text { case study A }\end{array}$ \\
\hline Canada/Alberta/Lindbergh & sand and tank bottoms & $\begin{array}{l}3,160 \mathrm{bbl} \text { waste } \\
\text { and } 23,860 \mathrm{bbl} \\
\text { total slurry }\end{array}$ & & & & & $\begin{array}{l}\text { listed in Terralog } \\
(2002 \mathrm{~b}) \text { as project } \\
\text { TT/8 }\end{array}$ \\
\hline Canada/Alberta/Wolf Lake & $\begin{array}{l}\text { tank bottoms and pit } \\
\text { material }\end{array}$ & $\begin{array}{l}32,421 \mathrm{bbl} \text { waste } \\
\text { and } 109,000 \mathrm{bbl} \\
\text { total slurry }\end{array}$ & & & & & $\begin{array}{l}\text { listed in Terralog } \\
(2002 b) \text { as project } \\
\text { TTI1 }\end{array}$ \\
\hline $\begin{array}{l}\text { Canada/Nova } \\
\text { Scotia/Panuke P1-1 }\end{array}$ & oily cuttings & 96,000 bbl slurry & $\begin{array}{l}\text { estimate: } \\
\text { density } 1.26 \\
\text { SG; viscosity } \\
161 \mathrm{cP} ; \\
\text { seawater used } \\
\text { as fluid }\end{array}$ & $\begin{array}{l}\text { cuttings are } \\
\text { ground }\end{array}$ & & & \\
\hline $\begin{array}{l}\text { Canada/Nova } \\
\text { Scotia/Panuke PP3C }\end{array}$ & oily cuttings & 19,476 bbl slurry & $\begin{array}{l}\text { estimate: } \\
\text { density } 1.26 \\
\text { SG; viscosity } \\
161 \mathrm{CP} \\
\text { seawater used } \\
\text { as fluid }\end{array}$ & $\begin{array}{l}\text { cuttings are } \\
\text { ground }\end{array}$ & & & \\
\hline Canada/Saskatchewan & oily sand & $\sim 63,000 \mathrm{bbl}$ & $\begin{array}{l}\text { density: } 1.08- \\
1.12\end{array}$ & & & & \\
\hline $\begin{array}{l}\text { Canada/Saskatchewan/ } \\
\text { Edam }\end{array}$ & $\begin{array}{l}\text { oily produced sand and } \\
\text { tank bottoms }\end{array}$ & $\begin{array}{l}85,000 \mathrm{bbl} \text { waste } \\
\text { and } 437,000 \mathrm{bbl} \\
\text { total slurry }\end{array}$ & & & $\begin{array}{l}\text { the well had previously } \\
\text { been perforated uphole and } \\
\text { was patched for use as an } \\
\text { injector; a poor cement } \\
\text { bond, large daily pressure } \\
\text { variations, and casing } \\
\text { deformation allowed fluids } \\
\text { to migrate to the patched } \\
\text { zone and leak out; the well } \\
\text { was then discontinued as an } \\
\text { injector }\end{array}$ & & $\begin{array}{l}\text { listed in Terralog } \\
\text { (2002b) as project } \\
\text { TT14; listed in } \\
\text { Dusseault and Bilak } \\
\text { (1998) as project 3; } \\
\text { listed in Sipple- } \\
\text { Srinivasan (1997) as } \\
\text { case study B }\end{array}$ \\
\hline $\begin{array}{l}\text { Canada/Saskatchewan/ } \\
\text { Edam }\end{array}$ & $\begin{array}{l}\text { sand, tank bottoms, } \\
\text { drilling mud }\end{array}$ & $\begin{array}{l}100,000 \mathrm{bbl} \\
\text { waste and } \\
556,000 \mathrm{bbl} \text { total } \\
\text { slurry }\end{array}$ & & & $\begin{array}{l}\text { to handle wastes with a } \\
\text { large range of } \\
\text { characteristics, materials } \\
\text { with different characteristics } \\
\text { were injected alternately }\end{array}$ & & $\begin{array}{l}\text { listed in Terralog } \\
\text { (2002b) as project } \\
\text { TTI6; listed in } \\
\text { Dusseault and Bilak } \\
\text { (1998) as project } 2 \\
\end{array}$ \\
\hline Chad/M-501 & cuttings & $\begin{array}{l}155,101 \mathrm{bbl} \\
\text { slurry }\end{array}$ & $8.3 \mathrm{lb} / \mathrm{gal}$ & & & & $\begin{array}{l}\text { limited data provided } \\
\text { for this job }\end{array}$ \\
\hline $\begin{array}{l}\text { Egypt/Gulf of } \\
\text { Suez/Ramadan 6-55 }\end{array}$ & $\begin{array}{l}\text { oily cuttings and } \\
\text { wastewater }\end{array}$ & $\begin{array}{l}200 \mathrm{bbl} \text { slurry } \\
\text { and } 400 \mathrm{bbl} \\
\text { wastewater }\end{array}$ & $\begin{array}{l}\text { density } 12.5 \\
\text { Ib/gal; } \\
\text { seawater used } \\
\text { for fluid }\end{array}$ & $\begin{array}{l}\text { centrifugal pump } \\
\text { used to break } \\
\text { solids into smaller } \\
\text { particles } \\
\end{array}$ & & & \\
\hline
\end{tabular}




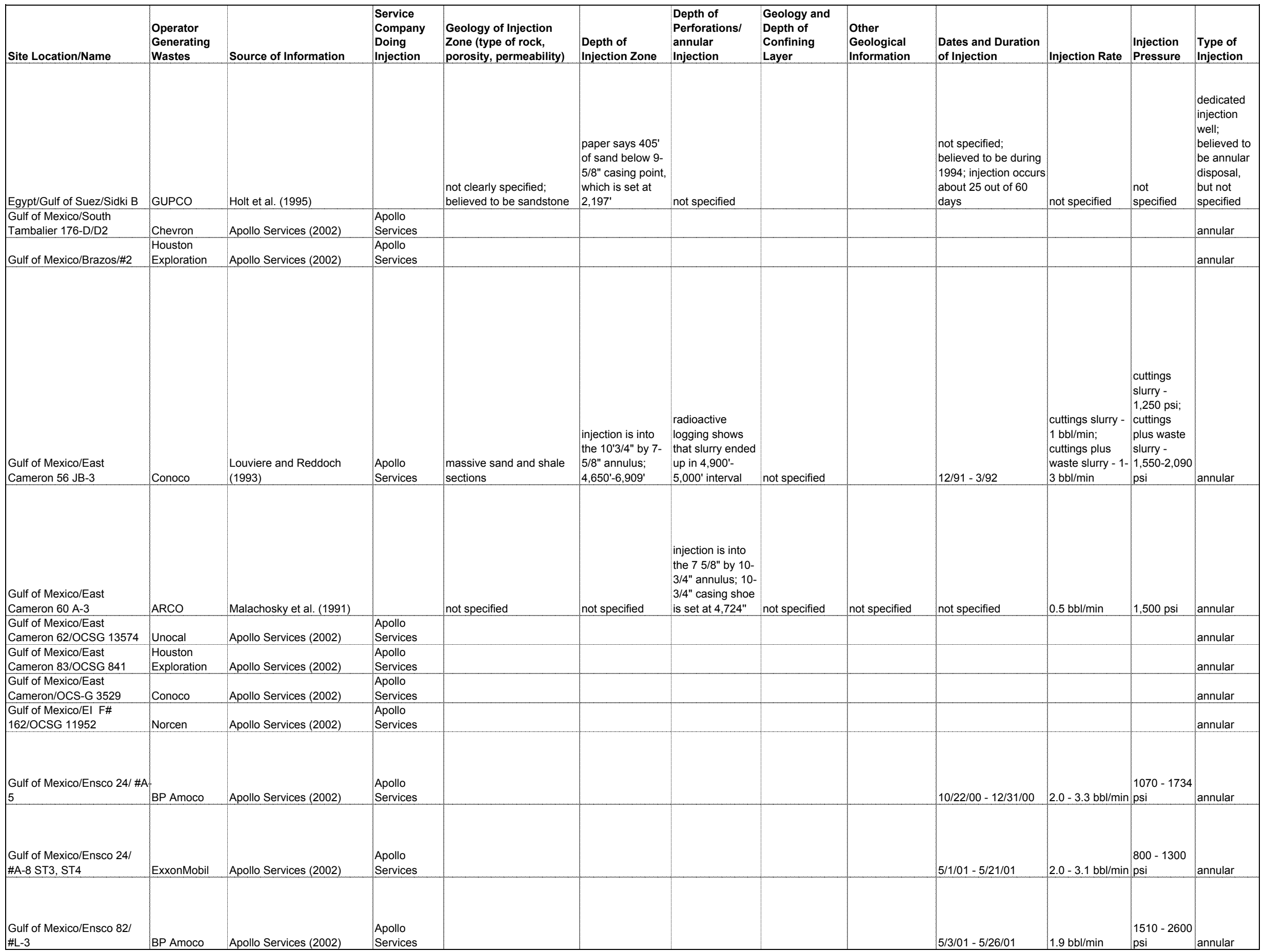




\begin{tabular}{|c|c|c|c|c|c|c|c|}
\hline Site Location/Name & Type of Waste Injected & $\begin{array}{l}\text { Volume of } \\
\text { Material } \\
\text { Injected } \\
\end{array}$ & $\begin{array}{l}\text { Slurry } \\
\text { Properties } \\
\text { (fluid, } \\
\text { density) } \\
\end{array}$ & $\begin{array}{l}\text { Pre-Injection } \\
\text { Processing/ } \\
\text { Treatment }\end{array}$ & Problems Experienced & Costs & Other Comments \\
\hline Egypt/Gulf of Suez/Sidki B & $\begin{array}{l}\text { oily cuttings, contaminated } \\
\text { mud, wastewater }\end{array}$ & $\begin{array}{l}3,150 \text { bbl } \\
\text { cuttings slurry; } \\
4,232 \text { bbl } \\
\text { contaminated } \\
\text { mud; } 13,514 \text { bbl } \\
\text { wastewater }\end{array}$ & $\begin{array}{l}\text { seawater used } \\
\text { as fluid }\end{array}$ & $\begin{array}{l}\text { centrifugal pump } \\
\text { used to break } \\
\text { solids into smaller } \\
\text { particles }\end{array}$ & $\begin{array}{l}\text { well plugged after injecting } \\
\text { - 7,200 bbl; solids were } \\
\text { cleaned out; problem solved } \\
\text { by pumping more seawater } \\
\text { after slurry injection batch to } \\
\text { flush the well }\end{array}$ & $\begin{array}{l}\text { estimated overall } \\
\text { cost for } \\
\text { construction and } \\
\text { O\&M of injection } \\
\text { system is } \\
\$ 24 / \text { bbl; onshore } \\
\text { land disposal at } \\
\text { company pit } \\
\text { costs about } \\
\$ 8 / \text { bbl }\end{array}$ & $\begin{array}{l}\text { this was a dedicated } \\
\text { injection well for the } \\
\text { Sidki redevelopment } \\
\text { program }\end{array}$ \\
\hline \begin{tabular}{|l|} 
Gulf of Mexico/South \\
Tambalier 176-D/D2 \\
\end{tabular} & cuttings & 13,639 bbl slurry & & & & & $\begin{array}{l}\text { limited data provided } \\
\text { for this job }\end{array}$ \\
\hline Gulf of Mexico/Brazos/\#2 & cuttings & 11,326 bbl slurry & & & & & $\begin{array}{l}\text { limited data provided } \\
\text { for this job }\end{array}$ \\
\hline $\begin{array}{l}\text { Gulf of Mexico/East } \\
\text { Cameron } 56 \mathrm{JB}-3 \\
\end{array}$ & $\begin{array}{l}\text { cuttings; some shredded } \\
\text { solid wastes; zinc bromide } \\
\text { completion fluid; } \\
\text { washwater }\end{array}$ & $\begin{array}{l}3,804 \text { bbl } \\
\text { cuttings; } 2,040 \\
\text { bbl slurry; } 5,043 \\
\text { bbl wastewater; } \\
13,330 \text { bbl } \\
\text { seawater; } 29,150 \\
\text { Ib shredded } \\
\text { waste; } 9,120 \mathrm{lb} \\
\text { food waste }\end{array}$ & $\begin{array}{l}\text { cuttings slurry: } \\
\text { density 10.29- } \\
10.39 \text { lb/gal; } \\
26.9-28.9 \% \\
\text { solids; cuttings } \\
\text { plus shredded } \\
\text { waste: density } \\
9.87-10.08 \\
\text { lb/gal }\end{array}$ & $\begin{array}{l}\text { cuttings are mixed } \\
\text { with water and } \\
\text { circulated through } \\
\text { a centrifugal pump } \\
\text { with hardened } \\
\text { cutters to reduce } \\
\text { particle size; } \\
\text { mixture is further } \\
\text { mixed in a second } \\
\text { blender where } \\
\text { shredded } \\
\text { nonhazardous } \\
\text { solid wastes are } \\
\text { added }\end{array}$ & $\begin{array}{l}\text { waste shredding generated } \\
\text { considerable dust; food } \\
\text { waste introduced moisture, } \\
\text { causing shredded waste to } \\
\text { swell and clog screens; } \\
\text { regular triplex injection } \\
\text { pump did not work well for } \\
\text { slurries containing } \\
\text { shredded waste }\end{array}$ & $\begin{array}{l}\text { \$295,000 for } \\
\text { injection of } \\
\text { cuttings and } \\
\text { other solid } \\
\text { wastes; } \\
\text { estimated cost to } \\
\text { haul the same } \\
\text { wastes onshore } \\
\text { for disposal is } \\
-\$ 46,000 \\
\end{array}$ & $\begin{array}{l}\text { project lasted longer } \\
\text { than projected due to } \\
\text { delays in drilling } \\
\text { (unrelated to } \\
\text { injection); this job } \\
\text { handled low rates of } \\
\text { cuttings generation }\end{array}$ \\
\hline $\begin{array}{l}\text { Gulf of Mexico/East } \\
\text { Cameron } 60 \mathrm{~A}-3 \\
\end{array}$ & oily cuttings & 1,270 bbl slurry & $\begin{array}{l}\text { typical } \\
\text { properties: } \\
\text { density } 11.2 \\
\text { Ib/gal; viscosity } \\
9 \mathrm{cps} \text {; solids } \\
22 \% \text {; seawater } \\
\text { used as fluid } \\
\end{array}$ & $\begin{array}{l}\text { cuttings are mixed } \\
\text { with water and } \\
\text { circulated through } \\
\text { a centrifugal pump } \\
\text { with hardened } \\
\text { cutters to reduce } \\
\text { particle size }\end{array}$ & & $\begin{array}{l}\text { savings of } \\
\$ 75,000-, \\
\$ 225,000 \text { per } \\
\text { well in waste } \\
\text { disposal costs; } \\
\text { no data provided } \\
\text { on capital and } \\
\text { operating costs }\end{array}$ & \\
\hline $\begin{array}{l}\text { Gulf of Mexico/East } \\
\text { Cameron 62/OCSG } 13574\end{array}$ & cuttings & 7,205 bbl slurry & & & & & $\begin{array}{l}\text { limited data provided } \\
\text { for this job }\end{array}$ \\
\hline $\begin{array}{l}\text { Gulf of Mexico/East } \\
\text { Cameron } 83 / \text { OCSG } 841\end{array}$ & cuttings & 2,120 bbl slurry & & & & & $\begin{array}{l}\text { limited data provided } \\
\text { for this job }\end{array}$ \\
\hline $\begin{array}{l}\text { Gulf of Mexico/East } \\
\text { Cameron/OCS-G } 3529\end{array}$ & cuttings & 21,842 bbl slurry & & & & & $\begin{array}{l}\text { limited data provided } \\
\text { for this job }\end{array}$ \\
\hline $\begin{array}{l}\text { Gulf of Mexico/El F\# } \\
\text { 162/OCSG 11952 }\end{array}$ & cuttings & 17,595 bbl slurry & & & & & $\begin{array}{l}\text { limited data provided } \\
\text { for this job }\end{array}$ \\
\hline $\begin{array}{l}\text { Gulf of Mexico/Ensco 24/ \# } \\
5\end{array}$ & $\begin{array}{l}\text {-cuttings, seawater, } \\
\text { prologic }\end{array}$ & $30,007 \mathrm{bbl}$ & $\begin{array}{l}8.8-11.5 \\
\text { lb/gal }\end{array}$ & $\begin{array}{l}\text { Prologic } \\
\text { (viscosifer) }\end{array}$ & & & $\begin{array}{l}\text { when not injecting, } \\
\text { slurry, need to inject } \\
\text { water every 4-6 } \\
\text { hours to maintain } \\
\text { hole integrity }\end{array}$ \\
\hline $\begin{array}{l}\text { Gulf of Mexico/Ensco 24/ } \\
\text { \#A-8 ST3, ST4 }\end{array}$ & $\begin{array}{l}\text { cuttings, seawater, } \\
\text { prologic }\end{array}$ & $4779 \mathrm{bbl}$ & $8.6-9.0 \mathrm{lb} / \mathrm{gal}$ & $\begin{array}{l}\text { Prologic } \\
\text { (viscosifer) }\end{array}$ & & & $\begin{array}{l}\text { when not injecting, } \\
\text { slurry, need to inject } \\
\text { water every 4-6 } \\
\text { hours to maintain } \\
\text { hole integrity } \\
\end{array}$ \\
\hline $\begin{array}{l}\text { Gulf of Mexico/Ensco 82/ } \\
\# \mathrm{HL}-3\end{array}$ & $\begin{array}{l}\text { washwater, centrifuge } \\
\text { discharge, cuttings } \\
\text { rainwater, prologic, } \\
\text { seawater }\end{array}$ & $11,318 \mathrm{bbl}$ & $\begin{array}{l}8.6-10.3 \\
\text { lb/gal }\end{array}$ & $\begin{array}{l}\text { Prologic } \\
\text { (viscosifer) }\end{array}$ & & & $\begin{array}{l}\text { when not injecting, } \\
\text { slurry, need to inject } \\
\text { water every 4-6 } \\
\text { hours to maintain } \\
\text { hole integrity }\end{array}$ \\
\hline
\end{tabular}




\begin{tabular}{|c|c|c|c|c|c|c|c|c|c|c|c|c|}
\hline Site Location/Name & $\begin{array}{l}\text { Operator } \\
\text { Generating } \\
\text { Wastes } \\
\end{array}$ & Source of Information & $\begin{array}{l}\text { Service } \\
\text { Company } \\
\text { Doing } \\
\text { Injection } \\
\end{array}$ & $\begin{array}{l}\text { Geology of Injection } \\
\text { Zone (type of rock, } \\
\text { porosity, permeability) }\end{array}$ & $\begin{array}{l}\text { Depth of } \\
\text { Injection Zone }\end{array}$ & $\begin{array}{l}\text { Depth of } \\
\text { Perforations/ } \\
\text { annular } \\
\text { Injection } \\
\end{array}$ & $\begin{array}{l}\text { Geology and } \\
\text { Depth of } \\
\text { Confining } \\
\text { Layer } \\
\end{array}$ & $\begin{array}{l}\text { Other } \\
\text { Geological } \\
\text { Information }\end{array}$ & $\begin{array}{l}\text { Dates and Duration } \\
\text { of Injection }\end{array}$ & Injection Rate & $\begin{array}{l}\text { Injection } \\
\text { Pressure }\end{array}$ & $\begin{array}{l}\text { Type of } \\
\text { Injection }\end{array}$ \\
\hline $\begin{array}{l}\text { Gulf of Mexico/Eugene } \\
\text { Island 158/NORM injection } \\
\text { well }\end{array}$ & Shell & $\begin{array}{l}\text { Hardy and Khatib (1996); } \\
\text { Satterlee (2003) }\end{array}$ & & permeable sand formation & $5,200^{\prime}$ & $5,200^{\prime}$ & $\begin{array}{l}\text { shale zones } \\
\text { above and } \\
\text { below sand layer }\end{array}$ & & $\begin{array}{l}4 \text { years beginning in } \\
1993\end{array}$ & $\begin{array}{l}\text { Phase I - 20 } \\
\text { bbl/min; Phases } \\
\text { II and III - } 4 \\
\text { bbl/min }\end{array}$ & $\begin{array}{l}\text { Phase I- } \\
5,000 \text { psi; } \\
\text { Phases II } \\
\text { and III - } \\
<2,000 \text { psi }\end{array}$ & annular \\
\hline $\begin{array}{l}\text { Gulf of Mexico/Eugene } \\
\text { Island } 158 / \# 30\end{array}$ & Shell & Apollo Services (2002) & $\begin{array}{l}\text { Apollo } \\
\text { Services }\end{array}$ & & & & & & & & & annular \\
\hline $\begin{array}{l}\text { Gulf of Mexico/Eugene } \\
\text { Island } 188 / \# 12\end{array}$ & Shell & Apollo Services (2002) & $\begin{array}{l}\text { Apollo } \\
\text { Services }\end{array}$ & & & & & & & & & annular \\
\hline $\begin{array}{l}\text { Gulf of Mexico/Eugene } \\
\text { Island } 188 / \mathrm{OCSG} 0443 / \# 30\end{array}$ & Shell & Apollo Services (2002) & $\begin{array}{l}\text { Apollo } \\
\text { Services } \\
\end{array}$ & & & & & & & & & annular \\
\hline $\begin{array}{l}\text { Gulf of Mexico/Eugene } \\
\text { Island } 259 \mathrm{C} / \# C 16\end{array}$ & Shell & Apollo Services (2002) & $\begin{array}{l}\text { Apollo } \\
\text { Services }\end{array}$ & & & & & & & & & annular \\
\hline $\begin{array}{l}\text { Gulf of Mexico/Eugene } \\
\text { Island 276/OCSG } 128233\end{array}$ & Unocal & Apollo Services (2002) & $\begin{array}{l}\text { Apollo } \\
\text { Services }\end{array}$ & & & & & & & & & annular \\
\hline $\begin{array}{l}\text { Gulf of Mexico/Eugene } \\
\text { Island } 331 / \# 38\end{array}$ & Shell & Apollo Services (2002) & $\begin{array}{l}\text { Apollo } \\
\text { Services }\end{array}$ & & & & & & & & & annular \\
\hline $\begin{array}{l}\text { Gulf of Mexico/Eugene } \\
\text { Island Block 65/\#1 }\end{array}$ & $\begin{array}{l}\text { Basin } \\
\text { Exploration }\end{array}$ & Apollo Services (2002) & $\begin{array}{l}\text { Apollo } \\
\text { Services }\end{array}$ & & & & & & & & & annular \\
\hline $\begin{array}{l}\text { Gulf of Mexico/Eugene } \\
\text { Island Block 65/\#2 }\end{array}$ & $\begin{array}{l}\text { Basin } \\
\text { Exploration }\end{array}$ & Apollo Services (2002) & $\begin{array}{l}\text { Apollo } \\
\text { Services }\end{array}$ & & & & & & & & & annular \\
\hline $\begin{array}{l}\text { Gulf of Mexico/Galveston } \\
239 / \# 1\end{array}$ & ARCO & Malachosky et al. (1991) & & layers of shale and sand & $\sim 3,600-5,310^{\prime}$ & $\begin{array}{l}\text { injection is into } \\
\text { the } 95 / 8 " \text { by } 13- \\
3 / 8 " \text { annulus; } 13- \\
3 / 8 " 2 " \text { casing } \\
\text { shoe is set at } \\
3,566 "\end{array}$ & & & $\begin{array}{l}\text { daily injections from } \\
5 / 2600-8 / 6 / 90\end{array}$ & $2 \mathrm{bbl} / \mathrm{min}$ & $2,000 \mathrm{psi}$ & annular \\
\hline $\begin{array}{l}\text { Gulf of Mexico/Galveston } \\
239 / \# 2\end{array}$ & ARCO & Malachosky et al. (1991) & & layers of shale and sand & not specified & $\begin{array}{l}\text { injection is into } \\
\text { the } 95 / 8 \text { " by } 13- \\
3 / 8 " \text { annulus; } 13- \\
3 / 8 \text { " casing shoe } \\
\text { is set at } 3,495^{\prime \prime}\end{array}$ & not specified & not specified & not specified & $3.5 \mathrm{bbl} / \mathrm{min}$ & $1,200 \mathrm{psi}$ & annular \\
\hline $\begin{array}{l}\text { Gulf of Mexico/Grand Isle } \\
41 / O C S-G 0130\end{array}$ & Conoco & Apollo Services (2002) & $\begin{array}{l}\text { Apollo } \\
\text { Services }\end{array}$ & & & & & & & & & annular \\
\hline $\begin{array}{l}\text { Gulf of Mexico/Grand Isle } \\
\text { 85/1D }\end{array}$ & Chevron & Apollo Services (2002) & $\begin{array}{l}\text { Apollo } \\
\text { Services } \\
\end{array}$ & & & & & & & & & annular \\
\hline $\begin{array}{l}\text { Gulf of Mexico/Grand Isle } \\
85 / 3 D\end{array}$ & Chevron & Apollo Services (2002) & $\begin{array}{l}\text { Apollo } \\
\text { Services }\end{array}$ & & & & & & & & & annular \\
\hline $\begin{array}{l}\text { Gulf of Mexico/Grand Isle } \\
85 / 11\end{array}$ & Chevron & Apollo Services (2002) & $\begin{array}{l}\text { Apollo } \\
\text { Services }\end{array}$ & & & & & & & & & annular \\
\hline $\begin{array}{l}\text { Gulf of Mexico/Grand Isle } \\
85 / 13\end{array}$ & Chevron & Apollo Services (2002) & $\begin{array}{l}\text { Apollo } \\
\text { Services }\end{array}$ & & & & & & & & & annular \\
\hline $\begin{array}{l}\text { Gulf of Mexico/Grand } \\
\text { Isle/OCS-G } 3413\end{array}$ & Conoco & Apollo Services (2002) & $\begin{array}{l}\text { Apollo } \\
\text { Services }\end{array}$ & & & & & & & & & annular \\
\hline $\begin{array}{l}\text { Gulf of Mexico/High Island } \\
389, \text { Flower Garden/OCSG } \\
2759\end{array}$ & $\begin{array}{l}\text { Mobile } \\
\text { Exploration }\end{array}$ & Apollo Services (2002) & $\begin{array}{l}\text { Apollo } \\
\text { Services }\end{array}$ & & & & & & & & & annular \\
\hline $\begin{array}{l}\text { Gulf of Mexico/Main Pass } \\
\text { 259/A-8 }\end{array}$ & Delmar & Apollo Services (2002) & $\begin{array}{l}\text { Apollo } \\
\text { Services }\end{array}$ & & & & & & & & & annular \\
\hline $\begin{array}{l}\text { Gulf of Mexico/Main Pass } \\
259 / A-9\end{array}$ & Delmar & Apollo Services (2002) & $\begin{array}{l}\text { Apollo } \\
\text { Services } \\
\end{array}$ & & & & & & & & & annular \\
\hline $\begin{array}{l}\text { Gulf of Mexico/Main Pass } \\
\text { Blk 239/\#1 }\end{array}$ & Shell & Apollo Services (2002) & $\begin{array}{l}\text { Apollo } \\
\text { Services } \\
\end{array}$ & & & & & & & & & annular \\
\hline
\end{tabular}




\begin{tabular}{|c|c|c|c|c|c|c|c|}
\hline Site Location/Name & Type of Waste Injected & $\begin{array}{l}\text { Volume of } \\
\text { Material } \\
\text { Injected } \\
\end{array}$ & $\begin{array}{l}\text { Slurry } \\
\text { Properties } \\
\text { (fluid, } \\
\text { density) } \\
\end{array}$ & $\begin{array}{l}\text { Pre-Injection } \\
\text { Processing/ } \\
\text { Treatment }\end{array}$ & Problems Experienced & Costs & Other Comments \\
\hline $\begin{array}{l}\text { Gulf of Mexico/Eugene } \\
\text { Island 158/NORM injection } \\
\text { well }\end{array}$ & NORM & 4,200 bbl NORM & $\begin{array}{l}8.5 \mathrm{lb} / \text { gal; } 40 \% \\
\text { NORM solids }\end{array}$ & $\begin{array}{l}\text { grinding; mixing } \\
\text { with mud gels; } \\
\text { circulated though } \\
\text { centrifugal pump } \\
\text { with hardened } \\
\text { cutters }\end{array}$ & & $\begin{array}{l}\text { costs reduced } \\
\text { from } \$ 1,200 / \mathrm{bbl} \\
\text { to } \$ 125 / \mathrm{bbl}\end{array}$ & $\begin{array}{l}\text { Shell experimented } \\
\text { with three different } \\
\text { methods of mixing } \\
\text { and injecting the } \\
\text { slurry to reduce } \\
\text { costs and improve } \\
\text { effectiveness }\end{array}$ \\
\hline \begin{tabular}{|l} 
Gulf of Mexico/Eugene \\
Island 158/\#30 \\
\end{tabular} & cuttings & 22,773 bbl slurry & & & & & $\begin{array}{l}\text { limited data provided } \\
\text { for this job }\end{array}$ \\
\hline $\begin{array}{l}\text { Gulf of Mexico/Eugene } \\
\text { Island } 188 / \# 12\end{array}$ & cuttings & 17,908 bbl slurry & & & & & $\begin{array}{l}\text { limited data provided } \\
\text { for this job }\end{array}$ \\
\hline \begin{tabular}{|l|} 
Gulf of Mexico/Eugene \\
Island $188 / \mathrm{OCSG} 0443 / \# 30$
\end{tabular} & cuttings & 11,427 bbl slurry & & & & & $\begin{array}{l}\text { limited data provided } \\
\text { for this job }\end{array}$ \\
\hline $\begin{array}{l}\text { Gulf of Mexico/Eugene } \\
\text { Island } 259 \mathrm{C} / \# \mathrm{C} 16\end{array}$ & cuttings & $36,588 \mathrm{bbl}$ slurry & & & & & $\begin{array}{l}\text { limited data provided } \\
\text { for this job }\end{array}$ \\
\hline $\begin{array}{l}\text { Gulf of Mexico/Eugene } \\
\text { Island 276/OCSG } 128233\end{array}$ & cuttings & 12,685 bbl slurry & & & & & $\begin{array}{l}\text { limited data provided } \\
\text { for this job }\end{array}$ \\
\hline $\begin{array}{l}\text { Gulf of Mexico/Eugene } \\
\text { Island } 331 / \# 38\end{array}$ & cuttings & $16,518 \mathrm{bbl}$ slurry & & & & & $\begin{array}{l}\text { limited data provided } \\
\text { for this job }\end{array}$ \\
\hline $\begin{array}{l}\text { Gulf of Mexico/Eugene } \\
\text { Island Block } 65 / \# 1\end{array}$ & cuttings & 12,240 bbl slurry & & & & & $\begin{array}{l}\text { limited data provided } \\
\text { for this job }\end{array}$ \\
\hline $\begin{array}{l}\text { Gulf of Mexico/Eugene } \\
\text { Island Block } 65 / \# 2\end{array}$ & cuttings & 12,240 bbl slurry & & & & & $\begin{array}{l}\text { limited data provided } \\
\text { for this job }\end{array}$ \\
\hline $\begin{array}{l}\text { Gulf of Mexico/Galveston } \\
239 / \# 1\end{array}$ & oily cuttings & 19,579 bbl slurry & \begin{tabular}{l|} 
typical \\
properties: \\
density 11.2 \\
Ib/gal; viscosity \\
$9 \mathrm{cps}$; solids \\
$22 \%$; seawater \\
used as fluid
\end{tabular} & $\begin{array}{l}\text { cuttings are mixed } \\
\text { with water and } \\
\text { circulated through } \\
\text { a centrifugal pump } \\
\text { with hardened } \\
\text { cutters to reduce } \\
\text { particle size }\end{array}$ & & $\begin{array}{l}\text { savings of } \\
\$ 75,000- \\
\$ 225,000 \text { per } \\
\text { well in waste } \\
\text { disposal costs; } \\
\text { no data provided } \\
\text { on capital and } \\
\text { operating costs }\end{array}$ & $\begin{array}{l}\text { paper notes that first } \\
\text { Gulf of Mexico } \\
\text { annular injection } \\
\text { permission was } \\
\text { received from the } \\
\text { MMS in late } 1986 \text { for } \\
\text { Ship Shoal Block } 332 \\
\text { A-3 well (no data } \\
\text { included) }\end{array}$ \\
\hline $\begin{array}{l}\text { Gulf of Mexico/Galveston } \\
239 / \# 2\end{array}$ & oily cuttings & 9,990 bbl slurry & $\begin{array}{l}\text { typical } \\
\text { properties: } \\
\text { density } 11.2 \\
\text { Ib/gal; viscosity } \\
9 \mathrm{cps} \text {; solids } \\
22 \% \text {; seawater } \\
\text { used as fluid }\end{array}$ & $\begin{array}{l}\text { cuttings are mixed } \\
\text { with water and } \\
\text { circulated through } \\
\text { a centrifugal pump } \\
\text { with hardened } \\
\text { cutters to reduce } \\
\text { particle size }\end{array}$ & & $\begin{array}{l}\text { savings of } \\
\$ 75,000- \\
\$ 225,000 \text { per } \\
\text { well in waste } \\
\text { disposal costs; } \\
\text { no data provided } \\
\text { on capital and } \\
\text { operating costs }\end{array}$ & \\
\hline $\begin{array}{l}\text { Gulf of Mexico/Grand Isle } \\
41 / \text { OCS-G } 0130\end{array}$ & cuttings & 6,512 bbl slurry & & & & & $\begin{array}{l}\text { limited data provided } \\
\text { for this job }\end{array}$ \\
\hline $\begin{array}{l}\text { Gulf of Mexico/Grand Isle } \\
\text { 85/1D }\end{array}$ & cuttings & 456 bbl slurry & & & & & $\begin{array}{l}\text { limited data provided } \\
\text { for this job }\end{array}$ \\
\hline $\begin{array}{l}\text { Gulf of Mexico/Grand Isle } \\
85 / 3 D\end{array}$ & cuttings & $559 \mathrm{bbl} \mathrm{slurry}$ & & & & & $\begin{array}{l}\text { limited data provided } \\
\text { for this job }\end{array}$ \\
\hline $\begin{array}{l}\text { Gulf of Mexico/Grand Isle } \\
85 / 11\end{array}$ & cuttings & 873 bbl slurry & & & & & $\begin{array}{l}\text { limited data provided } \\
\text { for this job }\end{array}$ \\
\hline $\begin{array}{l}\text { Gulf of Mexico/Grand Isle } \\
85 / 13\end{array}$ & cuttings & 763 bbl slurry & & & & & $\begin{array}{l}\text { limited data provided } \\
\text { for this job }\end{array}$ \\
\hline $\begin{array}{l}\text { Gulf of Mexico/Grand } \\
\text { Isle/OCS-G } 3413\end{array}$ & cuttings & 23,239 bbl slurry & & & & & $\begin{array}{l}\text { limited data provided } \\
\text { for this job }\end{array}$ \\
\hline $\begin{array}{l}\text { Gulf of Mexico//High Island } \\
389, \text { Flower Garden/OCSG } \\
2759\end{array}$ & cuttings & 8,375 bbl slurry & & & & & $\begin{array}{l}\text { limited data provided } \\
\text { for this job }\end{array}$ \\
\hline $\begin{array}{l}\text { Gulf of Mexico/Main Pass } \\
259 / A-8\end{array}$ & cuttings & 32,436 bbl slurry & & & & & $\begin{array}{l}\text { limited data provided } \\
\text { for this job }\end{array}$ \\
\hline $\begin{array}{l}\text { Gulf of Mexico/Main Pass } \\
259 / A-9\end{array}$ & cuttings & 24,925 bbl slurry & & & & & $\begin{array}{l}\text { limited data provided } \\
\text { for this job }\end{array}$ \\
\hline $\begin{array}{l}\text { Gulf of Mexico/Main Pass } \\
\text { Blk 239/\#1 }\end{array}$ & cuttings & 8,879 bbl slurry & & & & & $\begin{array}{l}\text { limited data provided } \\
\text { for this job }\end{array}$ \\
\hline
\end{tabular}




\begin{tabular}{|c|c|c|c|c|c|c|c|c|c|c|c|c|}
\hline Site Location/Name & $\begin{array}{l}\text { Operator } \\
\text { Generating } \\
\text { Wastes }\end{array}$ & Source of Information & $\begin{array}{l}\text { Service } \\
\text { Company } \\
\text { Doing } \\
\text { Injection } \\
\end{array}$ & $\begin{array}{l}\text { Geology of Injection } \\
\text { Zone (type of rock, } \\
\text { porosity, permeability) }\end{array}$ & $\begin{array}{l}\text { Depth of } \\
\text { Injection Zone }\end{array}$ & $\begin{array}{l}\text { Depth of } \\
\text { Perforations/ } \\
\text { annular } \\
\text { Injection } \\
\end{array}$ & $\begin{array}{l}\text { Geology and } \\
\text { Depth of } \\
\text { Confining } \\
\text { Layer }\end{array}$ & $\begin{array}{l}\text { Other } \\
\text { Geological } \\
\text { Information }\end{array}$ & $\begin{array}{l}\text { Dates and Duration } \\
\text { of Injection }\end{array}$ & Injection Rate & $\begin{array}{l}\text { Injection } \\
\text { Pressure }\end{array}$ & $\begin{array}{l}\text { Type of } \\
\text { Injection }\end{array}$ \\
\hline $\begin{array}{l}\text { Gulf of Mexico/Matagorda } \\
\text { Island } 545 / \# 1\end{array}$ & Walters & Apollo Services (2002) & $\begin{array}{l}\text { Apollo } \\
\text { Services }\end{array}$ & & & & & & & & & annular \\
\hline $\begin{array}{l}\text { Gulf of Mexico/Matagorda } \\
\text { Island 565/OCSG } 4138\end{array}$ & Walters & Apollo Services (2002) & $\begin{array}{l}\text { Apollo } \\
\text { Services }\end{array}$ & & & & & & & & & annular \\
\hline $\begin{array}{l}\text { Gulf of Mexico/Matagorda } \\
\text { Island 591/\#1 }\end{array}$ & ARCO & Malachosky et al. (1991) & & not specified & not specified & \begin{tabular}{|l|} 
injection is into \\
the $95 / 8$ " by $13-$ \\
$3 / 8 "$ annulus; $13-$ \\
$3 / 8 "$ casing shoe \\
is set at $4,490 "$
\end{tabular} & not specified & not specified & not specified & $4 \mathrm{bbl} / \mathrm{min}$ & $1,800 \mathrm{psi}$ & annular \\
\hline $\begin{array}{l}\text { Gulf of Mexico/Mustang } \\
\text { Island } 704 / \# 4\end{array}$ & $\begin{array}{l}\text { Houston } \\
\text { Exploration }\end{array}$ & Apollo Services (2002) & $\begin{array}{l}\text { Apollo } \\
\text { Services }\end{array}$ & & & $4,730^{\prime}$ & & & $1 / 5 / 00-3 / 23 / 00$ & $1.8-2.7 \mathrm{bbl} / \mathrm{min}$ & $\begin{array}{l}700-1,500 \\
\text { psi }\end{array}$ & annular \\
\hline $\begin{array}{l}\text { Gulf of Mexico/Mustang } \\
\text { Island 858/A-4 }\end{array}$ & $\begin{array}{l}\text { Houston } \\
\text { Exploration }\end{array}$ & Apollo Services (2002) & $\begin{array}{l}\text { Apollo } \\
\text { Services }\end{array}$ & & & & & & 12/10/97 - 2/19/98 & $1.5-3.0 \mathrm{bbl} / \mathrm{min}$ & $\begin{array}{l}425-1,600 \\
\text { psi }\end{array}$ & annular \\
\hline $\begin{array}{l}\text { Gulf of Mexico/Mustang } \\
\text { Island 858/OCSG } 12421 \# 2\end{array}$ & $\begin{array}{l}\text { Houston } \\
\text { Exploration }\end{array}$ & Apollo Services (2002) & $\begin{array}{l}\text { Apollo } \\
\text { Services }\end{array}$ & & & & & & $12 / 14 / 97-1 / 2 / 98$ & $2 \mathrm{bbl} / \mathrm{min}$ & $\begin{array}{l}700-1375 \\
\text { psi }\end{array}$ & annular \\
\hline Gulf of Mexico/Nohoch C & Pemex & MI/SWACO (2002) & Ml/SWACO & & & & & & $2 / 01-9 / 02$ & $2-2.5 \mathrm{bbl} / \mathrm{min}$ & & $\begin{array}{l}\text { dedicated } \\
\text { well; inject } \\
\text { though } \\
\text { casing }\end{array}$ \\
\hline $\begin{array}{l}\text { Gulf of Mexico/Ship Shoal } \\
117 / \# 37\end{array}$ & Murphy & Apollo Services (2002) & $\begin{array}{l}\text { Apollo } \\
\text { Services }\end{array}$ & & & & & & & & & annular \\
\hline $\begin{array}{l}\text { Gulf of Mexico/Ship Shoal } \\
\text { 218/B-7s/t }\end{array}$ & Kerr McGee & Apollo Services (2002) & $\begin{array}{l}\text { Apollo } \\
\text { Services }\end{array}$ & & & & & & & & & annular \\
\hline $\begin{array}{l}\text { Gulf of Mexico/Ship Shoal } \\
239 / \mathrm{B}-9\end{array}$ & Kerr McGee & Apollo Services (2002) & $\begin{array}{l}\text { Apollo } \\
\text { Services }\end{array}$ & & & & & & & & & annular \\
\hline $\begin{array}{l}\text { Gulf of Mexico/Ship Shoal } \\
253 / C-12\end{array}$ & Unocal & Apollo Services (2002) & $\begin{array}{l}\text { Apollo } \\
\text { Services }\end{array}$ & & & & & & & & & annular \\
\hline $\begin{array}{l}\text { Gulf of Mexico/Ship Shoal } \\
254 / A-6\end{array}$ & Unocal & Apollo Services (2002) & $\begin{array}{l}\text { Apollo } \\
\text { Services }\end{array}$ & & & & & & & & & annular \\
\hline $\begin{array}{l}\text { Gulf of Mexico/Ship Shoal } \\
93 / \# 9\end{array}$ & Murphy & Apollo Services (2002) & $\begin{array}{l}\text { Apollo } \\
\text { Services }\end{array}$ & & & & & & & & & annular \\
\hline $\begin{array}{l}\text { Gulf of Mexico/South Marsh } \\
\text { Island } 49 / 787\end{array}$ & Unocal & Apollo Services (2002) & $\begin{array}{l}\text { Apollo } \\
\text { Services }\end{array}$ & & & & & & & & & annular \\
\hline $\begin{array}{l}\text { Gulf of Mexico/South Marsh } \\
\text { Island 6/A-29 }\end{array}$ & Unocal & Apollo Services (2002) & $\begin{array}{l}\text { Apollo } \\
\text { Services }\end{array}$ & & & & & & $9 / 3 / 02-10 / 26 / 02$ & $1.6-3.4 \mathrm{bbl} / \mathrm{min}$ & $\begin{array}{l}400-1287 \\
\text { psi }\end{array}$ & annular \\
\hline $\begin{array}{l}\text { Gulf of Mexico/South Pass } \\
\text { 89A, Blk 93/A-11, ST2 }\end{array}$ & ExxonMobil & Apollo Services (2002) & $\begin{array}{l}\text { Apollo } \\
\text { Services }\end{array}$ & & & 3,604 & & & $5 / 1 / 01-5 / 21 / 01$ & $2.0-3.1 \mathrm{bbl} / \mathrm{min}$ & $\begin{array}{l}925-1,273 \\
\text { psi }\end{array}$ & annular \\
\hline $\begin{array}{l}\text { Gulf of Mexico/South Pass } \\
\text { 89A, Blk 93/A-2, ST1 }\end{array}$ & ExxonMobil & Apollo Services (2002) & $\begin{array}{l}\text { Apollo } \\
\text { Services }\end{array}$ & & & & & & $9 / 9 / 00-10 / 22 / 00$ & $2.7-5.3 \mathrm{bbl} / \mathrm{min}$ & $\begin{array}{l}\text { 745-1,295 } \\
\text { psi }\end{array}$ & annular \\
\hline $\begin{array}{l}\text { Gulf of Mexico/South Pass } \\
\text { 89A, Blk 93/A-4 }\end{array}$ & ExxonMobil & Apollo Services (2002) & $\begin{array}{l}\text { Apollo } \\
\text { Services }\end{array}$ & & & $4,613^{\prime}$ & & & $1 / 11 / 01-3 / 5 / 01$ & $1.4-3.8 \mathrm{bbl} / \mathrm{min}$ & $\begin{array}{l}550-1,200 \\
\mathrm{psi}\end{array}$ & annular \\
\hline $\begin{array}{l}\text { Gulf of Mexico/South Pass } \\
\text { 89A, Blk 93/A-8, ST1 }\end{array}$ & ExxonMobil & Apollo Services (2002) & $\begin{array}{l}\text { Apollo } \\
\text { Services }\end{array}$ & & & & & & $10 / 23 / 00-12 / 31 / 00$ & $2.0-3.3 \mathrm{bbl} / \mathrm{min}$ & $\begin{array}{l}926-1,734 \\
\text { psi }\end{array}$ & annular \\
\hline $\begin{array}{l}\text { Gulf of Mexico/South Pass } \\
\text { 89A, Blk 93/A-8, ST4 }\end{array}$ & ExxonMobil & Apollo Services (2002) & $\begin{array}{l}\text { Apollo } \\
\text { Services }\end{array}$ & & & $3,604^{\prime}$ & & & $8 / 7 / 01-8 / 26 / 01$ & $2.0-2.7 \mathrm{bbl} / \mathrm{min}$ & $\begin{array}{l}800-1275 \\
\text { psi }\end{array}$ & annular \\
\hline $\begin{array}{l}\text { Gulf of Mexico/Vermilion Blk. } \\
\text { 255/OCSG } 1152\end{array}$ & Forest Oil & Apollo Services (2002) & $\begin{array}{l}\text { Apollo } \\
\text { Services }\end{array}$ & & & & & & & & & annular \\
\hline $\begin{array}{l}\text { Gulf of Mexico/Vermillion } \\
200 / \# 1\end{array}$ & Shell & Apollo Services (2002) & $\begin{array}{l}\text { Apollo } \\
\text { Services }\end{array}$ & & & & & & & & & annular \\
\hline $\begin{array}{l}\text { Gulf of Mexico/Vermillion } \\
26 / \# 41 \text { ST-2 }\end{array}$ & Unocal & Apollo Services (2002) & $\begin{array}{l}\text { Apollo } \\
\text { Services }\end{array}$ & & & $10,018^{\prime}$ & & & 10/11/98 - 1/5/99 & $1.1-2.8 \mathrm{bbl} / \mathrm{min}$ & $\begin{array}{l}400-1,000 \\
\mathrm{psi}\end{array}$ & annular \\
\hline $\begin{array}{l}\text { Gulf of Mexico/Vermillion } \\
38 / \# 1\end{array}$ & Unocal & Apollo Services (2002) & $\begin{array}{l}\text { Apollo } \\
\text { Services }\end{array}$ & & & & & & & & & annular \\
\hline $\begin{array}{l}\text { Gulf of Mexico/Vermillion } \\
39 / \# 2\end{array}$ & Unocal & Apollo Services (2002) & $\begin{array}{l}\text { Apollo } \\
\text { Services }\end{array}$ & & & & & & & & & annular \\
\hline $\begin{array}{l}\text { Gulf of Mexico/West } \\
\text { Cameron 201/OCS-G } 0764\end{array}$ & Arco & Apollo Services (2002) & $\begin{array}{l}\text { Apollo } \\
\text { Services }\end{array}$ & & & & & & & & & annular \\
\hline
\end{tabular}




\begin{tabular}{|c|c|c|c|c|c|c|c|}
\hline Site Location/Name & Type of Waste Injected & $\begin{array}{l}\text { Volume of } \\
\text { Material } \\
\text { Injected } \\
\end{array}$ & $\begin{array}{l}\text { Slurry } \\
\text { Properties } \\
\text { (fluid, } \\
\text { density) }\end{array}$ & $\begin{array}{l}\text { Pre-Injection } \\
\text { Processing/ } \\
\text { Treatment }\end{array}$ & Problems Experienced & Costs & Other Comments \\
\hline $\begin{array}{l}\text { Gulf of Mexico/Matagorda } \\
\text { Island } 545 / \# 1\end{array}$ & cuttings & 10,832 bbl slurry & & & & & $\begin{array}{l}\text { limited data provided } \\
\text { for this job }\end{array}$ \\
\hline \begin{tabular}{|l|} 
Gulf of Mexico/Matagorda \\
Island 565/OCSG 4138
\end{tabular} & cuttings & 11,348 bbl slurry & & & & & $\begin{array}{l}\text { limited data provided } \\
\text { for this job }\end{array}$ \\
\hline $\begin{array}{l}\text { Gulf of Mexico/Matagorda } \\
\text { Island } 591 / \# 1\end{array}$ & oily cuttings & 9,560 bbl slurry & $\begin{array}{l}\text { typical } \\
\text { properties: } \\
\text { density } 11.2 \\
\text { Ib/gal; viscosity } \\
9 \mathrm{cps} \text {; solids } \\
22 \% \text {; seawater } \\
\text { used as fluid }\end{array}$ & $\begin{array}{l}\text { cuttings are mixed } \\
\text { with water and } \\
\text { circulated through } \\
\text { a centrifugal pump } \\
\text { with hardened } \\
\text { cutters to reduce } \\
\text { particle size }\end{array}$ & & $\begin{array}{l}\text { savings of } \\
\$ 75,000- \\
\$ 225,000 \text { per } \\
\text { well in waste } \\
\text { disposal costs; } \\
\text { no data provided } \\
\text { on capital and } \\
\text { operating costs }\end{array}$ & \\
\hline $\begin{array}{l}\text { Gulf of Mexico/Mustang } \\
\text { Island 704/\#4 }\end{array}$ & cuttings & 3,667 bbl slurry & $9.3-11.3 \mathrm{lb} / \mathrm{gal}$ & & & & $\begin{array}{l}\text { limited data provided } \\
\text { for this job }\end{array}$ \\
\hline $\begin{array}{l}\text { Gulf of Mexico/Mustang } \\
\text { Island 858/A-4 }\end{array}$ & cuttings & 14,172 bbl slurry & $9.1-16.2 \mathrm{lb} / \mathrm{gal}$ & & & & $\begin{array}{l}\text { limited data provided } \\
\text { for this job }\end{array}$ \\
\hline \begin{tabular}{|l|} 
Gulf of Mexico/Mustang \\
Island 858/OCSG 12421 \#2
\end{tabular} & cuttings & 7,350 bbl slurry & $8.6-11.4 \mathrm{lb} / \mathrm{gal}$ & & & & $\begin{array}{l}\text { limited data provided } \\
\text { for this job }\end{array}$ \\
\hline Gulf of Mexico/Nohoch C & oil-based cuttings & $147,072 \mathrm{bbl}$ & & & & & $\begin{array}{l}\text { same as } \\
\text { Alaska/North } \\
\text { Slope/Alpine }\end{array}$ \\
\hline $\begin{array}{l}\text { Gulf of Mexico/Ship Shoal } \\
117 / \# 37\end{array}$ & cuttings & 1,187 bbl slurry & & & & & $\begin{array}{l}\text { limited data provided } \\
\text { for this job }\end{array}$ \\
\hline $\begin{array}{l}\text { Gulf of Mexico/Ship Shoal } \\
218 / \mathrm{B}-7 \mathrm{~s} / \mathrm{t}\end{array}$ & cuttings & 28,913 bbl slurry & & & & & $\begin{array}{l}\text { limited data provided } \\
\text { for this job }\end{array}$ \\
\hline $\begin{array}{l}\text { Gulf of Mexico/Ship Shoal } \\
239 / \text { B-9 }\end{array}$ & cuttings & 25,679 bbl slurry & & & & & $\begin{array}{l}\text { limited data provided } \\
\text { for this job }\end{array}$ \\
\hline $\begin{array}{l}\text { Gulf of Mexico/Ship Shoal } \\
253 / \text { C-12 }\end{array}$ & cuttings & 7,500 bbl slurry & & & & & $\begin{array}{l}\text { limited data provided } \\
\text { for this job }\end{array}$ \\
\hline $\begin{array}{l}\text { Gulf of Mexico/Ship Shoal } \\
254 / A-6\end{array}$ & cuttings & 9,263 bbl slurry & & & & & $\begin{array}{l}\text { limited data provided } \\
\text { for this job }\end{array}$ \\
\hline $\begin{array}{l}\text { Gulf of Mexico/Ship Shoal } \\
\text { 93/\#9 }\end{array}$ & cuttings & 674 bbl slurry & & & & & $\begin{array}{l}\text { limited data provided } \\
\text { for this job }\end{array}$ \\
\hline $\begin{array}{l}\text { Gulf of Mexico/South Marsh } \\
\text { Island 49/787 }\end{array}$ & cuttings & 21,426 bbl slurry & & & & & $\begin{array}{l}\text { limited data provided } \\
\text { for this job }\end{array}$ \\
\hline $\begin{array}{l}\text { Gulf of Mexico/South Marsh } \\
\text { Island 6/A-29 } \\
\text { sla }\end{array}$ & cuttings & 13,66 bbl slurry & $8.6-14.0 \mathrm{lb} / \mathrm{gal}$ & & & & $\begin{array}{l}\text { limited data provided } \\
\text { for this job }\end{array}$ \\
\hline $\begin{array}{l}\text { Gulf of Mexico/South Pass } \\
\text { 89A, Blk 93/A-11, ST2 }\end{array}$ & cuttings & 4,779 bbl slurry & $8.6-9.0 \mathrm{lb} / \mathrm{gal}$ & & & & $\begin{array}{l}\text { limited data provided } \\
\text { for this job }\end{array}$ \\
\hline $\begin{array}{l}\text { Gulf of Mexico/South Pass } \\
\text { 89A, Blk 93/A-2, ST1 }\end{array}$ & cuttings & 15,438 bbl slurry & $9.0-10.2 \mathrm{lb} / \mathrm{gal}$ & & & & $\begin{array}{l}\text { limited data provided } \\
\text { for this job }\end{array}$ \\
\hline $\begin{array}{l}\text { Gulf of Mexico/South Pass } \\
\text { 89A, Blk 93/A-4 }\end{array}$ & cuttings & 29,951 bbl slurry & $8.7-11.5 \mathrm{lb} / \mathrm{gal}$ & & & & $\begin{array}{l}\text { limited data provided } \\
\text { for this job }\end{array}$ \\
\hline $\begin{array}{l}\text { Gulf of Mexico/South Pass } \\
\text { 89A, Blk 93/A-8, ST1 }\end{array}$ & cuttings & 23,960 bbl slurry & $8.8-11.5 \mathrm{lb} / \mathrm{gal}$ & & & & $\begin{array}{l}\text { limited data provided } \\
\text { for this job }\end{array}$ \\
\hline $\begin{array}{l}\text { Gulf of Mexico/South Pass } \\
\text { 89A, Blk 93/A-8, ST4 }\end{array}$ & cuttings & 3,563 bbl slurry & $9.0-11.0 \mathrm{lb} / \mathrm{gal}$ & & & & $\begin{array}{l}\text { limited data provided } \\
\text { for this job }\end{array}$ \\
\hline $\begin{array}{l}\text { Gulf of Mexico/Vermilion Blk. } \\
255 / \text { OCSG } 1152\end{array}$ & cuttings & 5,693 bbl slurry & & & & & $\begin{array}{l}\text { limited data provided } \\
\text { for this job }\end{array}$ \\
\hline $\begin{array}{l}\text { Gulf of Mexico/Vermillion } \\
200 / \# 1\end{array}$ & cuttings & 12,860 bbl slurry & & & & & $\begin{array}{l}\text { limited data provided } \\
\text { for this job }\end{array}$ \\
\hline $\begin{array}{l}\text { Gulf of Mexico/Vermillion } \\
26 / \# 41 \text { ST-2 }\end{array}$ & cuttings & 15,212 bbl slurry & $8.2-12.0 \mathrm{lb} / \mathrm{gal}$ & & & & $\begin{array}{l}\text { limited data provided } \\
\text { for this job }\end{array}$ \\
\hline $\begin{array}{l}\text { Gulf of Mexico/Vermillion } \\
38 / \# 1\end{array}$ & cuttings & 17,822 bbl slurry & & & & & $\begin{array}{l}\text { limited data provided } \\
\text { for this job }\end{array}$ \\
\hline $\begin{array}{l}\text { Gulf of Mexico/Vermillion } \\
39 / \# 2\end{array}$ & cuttings & 17,822 bbl slurry & & & & & $\begin{array}{l}\text { limited data provided } \\
\text { for this job }\end{array}$ \\
\hline \begin{tabular}{|l|} 
Gulf of Mexico/West \\
Cameron 201/OCS-G 0764
\end{tabular} & cuttings & 10,196 bbl slurry & & & & & $\begin{array}{l}\text { limited data provided } \\
\text { for this job }\end{array}$ \\
\hline
\end{tabular}




\begin{tabular}{|c|c|c|c|c|c|c|c|c|c|c|c|c|}
\hline Site Location/Name & $\begin{array}{l}\text { Operator } \\
\text { Generating } \\
\text { Wastes } \\
\end{array}$ & Source of Information & $\begin{array}{l}\text { Service } \\
\text { Company } \\
\text { Doing } \\
\text { Injection } \\
\end{array}$ & $\begin{array}{l}\text { Geology of Injection } \\
\text { Zone (type of rock, } \\
\text { porosity, permeability) }\end{array}$ & $\begin{array}{l}\text { Depth of } \\
\text { Injection Zone }\end{array}$ & $\begin{array}{l}\text { Depth of } \\
\text { Perforations/ } \\
\text { annular } \\
\text { Injection } \\
\end{array}$ & $\begin{array}{l}\text { Geology and } \\
\text { Depth of } \\
\text { Confining } \\
\text { Layer } \\
\end{array}$ & $\begin{array}{l}\text { Other } \\
\text { Geological } \\
\text { Information }\end{array}$ & $\begin{array}{l}\text { Dates and Duration } \\
\text { of Injection }\end{array}$ & Injection Rate & $\begin{array}{l}\text { Injection } \\
\text { Pressure } \\
\end{array}$ & $\begin{array}{l}\text { Type of } \\
\text { Injection }\end{array}$ \\
\hline $\begin{array}{l}\text { Gulf of Mexico/West } \\
\text { Cameron 174/OCSG } 17766\end{array}$ & $\begin{array}{l}\text { Houston } \\
\text { Exploration } \\
\end{array}$ & Apollo Services (2002) & $\begin{array}{l}\text { Apollo } \\
\text { Services }\end{array}$ & & & & & & & & & annular \\
\hline $\begin{array}{l}\text { Gulf of Mexico/West } \\
\text { Cameron } 196 / \mathrm{A}-10\end{array}$ & Unocal & Apollo Services (2002) & $\begin{array}{l}\text { Apollo } \\
\text { Services }\end{array}$ & & & & & & $5 / 10 / 97-5 / 19 / 97$ & $2 \mathrm{bbl} / \mathrm{min}$ & $\begin{array}{l}1,100-1,600 \\
\text { psi }\end{array}$ & annular \\
\hline $\begin{array}{l}\text { Gulf of Mexico/West } \\
\text { Cameron 196/A-11 } \\
\end{array}$ & Unocal & Apollo Services (2002) & $\begin{array}{l}\text { Apollo } \\
\text { Services }\end{array}$ & & & & & & 7/24/98 - 8/9/98 & $0.5-3.3 \mathrm{bbl} / \mathrm{min}$ & $\begin{array}{l}\text { 1,050-1,650 } \\
\text { psi }\end{array}$ & annular \\
\hline $\begin{array}{l}\text { Gulf of Mexico/West } \\
\text { Cameron 196/A-12 }\end{array}$ & Unocal & Apollo Services (2002) & $\begin{array}{l}\text { Apollo } \\
\text { Services }\end{array}$ & & & & & & $8 / 10 / 98-8 / 29 / 98$ & $2.0-2.8 \mathrm{bb} / \mathrm{min}$ & & annular \\
\hline $\begin{array}{l}\text { Gulf of Mexico/West } \\
\text { Cameron 196/A-9 }\end{array}$ & Unocal & Apollo Services (2002) & $\begin{array}{l}\text { Apollo } \\
\text { Services }\end{array}$ & & & $4,225^{\prime}$ & & & 5/20/97- 7/29/99 & $1.5-3.0 \mathrm{bbl} / \mathrm{min}$ & $\begin{array}{l}\text { 1,000-1,550 } \\
\text { psi }\end{array}$ & annular \\
\hline $\begin{array}{l}\text { Gulf of Mexico/West } \\
\text { Cameron 280/B-5 }\end{array}$ & Unocal & Apollo Services (2002) & $\begin{array}{l}\text { Apollo } \\
\text { Services }\end{array}$ & & & & & & $1 / 29 / 98-3 / 27 / 98$ & $2.0-4.0 \mathrm{bbl} / \mathrm{min}$ & $\begin{array}{l}450-1,050 \\
\text { psi }\end{array}$ & annular \\
\hline $\begin{array}{l}\text { Gulf of Mexico/West } \\
\text { Cameron 280/OCSG } 15074\end{array}$ & Unocal & Apollo Services (2002) & $\begin{array}{l}\text { Apollo } \\
\text { Services }\end{array}$ & & & & & & & & & annular \\
\hline $\begin{array}{l}\text { Gulf of Mexico/West } \\
\text { Cameron 53/OCSG } 4379\end{array}$ & ZilkHa & Apollo Services (2002) & $\begin{array}{l}\text { Apollo } \\
\text { Services }\end{array}$ & & & & & & & & & annular \\
\hline India/Panna Field/PC4 & $\begin{array}{l}\text { Enron Oil \& } \\
\text { Gas India Ltd. }\end{array}$ & Apollo Services (2002) & $\begin{array}{l}\text { Apollo } \\
\text { Services }\end{array}$ & & & & & & & & & annular \\
\hline India/Panna Field/PC5 & $\begin{array}{l}\text { Enron Oil \& } \\
\text { Gas India Ltd. }\end{array}$ & Apollo Services (2002) & $\begin{array}{l}\text { Apollo } \\
\text { Services }\end{array}$ & & & & & & & & & annular \\
\hline India/Panna Field/PC6 & $\begin{array}{l}\text { Enron Oil \& } \\
\text { Gas India Ltd. }\end{array}$ & Apollo Services (2002) & $\begin{array}{l}\text { Apollo } \\
\text { Services }\end{array}$ & & & & & & $5 / 17 / 98-6 / 4 / 98$ & $2.0-3.0 \mathrm{bb} / \mathrm{min}$ & $\begin{array}{l}1,200-1,600 \\
\text { psi }\end{array}$ & annular \\
\hline India/Panna Field/PC8 & $\begin{array}{l}\text { Enron Oil \& } \\
\text { Gas India Ltd. }\end{array}$ & Apollo Services (2002) & $\begin{array}{l}\text { Apollo } \\
\text { Services }\end{array}$ & & & & & & & & & annular \\
\hline India/Panna Field/PF10 & $\begin{array}{l}\text { Enron Oil \& } \\
\text { Gas India Ltd. }\end{array}$ & Apollo Services (2002) & $\begin{array}{l}\text { Apollo } \\
\text { Services }\end{array}$ & & & & & & 4/6/98 - 4/13/98 & $2.0-3.0 \mathrm{bb} / \mathrm{min}$ & $\begin{array}{l}\text { 100-1,100 } \\
\text { psi }\end{array}$ & annular \\
\hline India/Panna Field/PF11 & $\begin{array}{l}\text { Enron Oil \& } \\
\text { Gas India Ltd. }\end{array}$ & Apollo Services (2002) & $\begin{array}{l}\text { Apollo } \\
\text { Services }\end{array}$ & & & & & & $5 / 4 / 98-5 / 16 / 98$ & $2.0 \mathrm{bbl} / \mathrm{min}$ & $\begin{array}{l}1,300-1,900 \\
\text { psi }\end{array}$ & annular \\
\hline India/Panna Field/PF12 & $\begin{array}{l}\text { Enron Oil \& } \\
\text { Gas India Ltd. }\end{array}$ & Apollo Services (2002) & $\begin{array}{l}\text { Apollo } \\
\text { Services }\end{array}$ & & & & & & $8 / 8 / 98-8 / 15 / 98$ & $1.9-2.0 \mathrm{bbl} / \mathrm{min}$ & $\begin{array}{l}1,250-1,550 \\
\text { psi }\end{array}$ & annular \\
\hline India/Panna Field/PF14-H & $\begin{array}{l}\text { Enron Oil \& } \\
\text { Gas India Ltd. }\end{array}$ & Apollo Services (2002) & $\begin{array}{l}\text { Apollo } \\
\text { Services }\end{array}$ & & & & & & $8 / 26 / 98-9 / 11 / 98$ & $1.9-2.0 \mathrm{bb} / \mathrm{min}$ & $\begin{array}{l}1,200-2,000 \\
\text { psi }\end{array}$ & annular \\
\hline India/Panna Field/PF3 & $\begin{array}{l}\text { Enron Oil \& } \\
\text { Gas India Ltd. }\end{array}$ & Apollo Services (2002) & $\begin{array}{l}\text { Apollo } \\
\text { Services }\end{array}$ & & & & & & $7 / 29 / 98-7 / 31 / 98$ & $1.9 \mathrm{bbl} / \mathrm{min}$ & $\begin{array}{l}1,000-1,350 \\
\text { psi }\end{array}$ & annular \\
\hline India/Panna Field/PF5 & $\begin{array}{l}\text { Enron Oil \& } \\
\text { Gas India Ltd. }\end{array}$ & Apollo Services (2002) & $\begin{array}{l}\text { Apollo } \\
\text { Services }\end{array}$ & & & & & & $4 / 14 / 98-4 / 21 / 98$ & $2.0-3.0 \mathrm{bbl} / \mathrm{min}$ & $\begin{array}{l}950-1,400 \\
\text { psi }\end{array}$ & annular \\
\hline India/Panna Field/PF6 & $\begin{array}{l}\text { Enron Oil \& } \\
\text { Gas India Ltd. }\end{array}$ & Apollo Services (2002) & $\begin{array}{l}\text { Apollo } \\
\text { Services }\end{array}$ & & & & & & $422 / 98-5 / 3 / 98$ & $2.0 \mathrm{bbl} / \mathrm{min}$ & $\begin{array}{l}1,100-1,700 \\
\text { psi }\end{array}$ & annular \\
\hline India/Panna Field/PF8 & $\begin{array}{l}\text { Enron Oil \& } \\
\text { Gas India Ltd. }\end{array}$ & Apollo Services (2002) & $\begin{array}{l}\text { Apollo } \\
\text { Services }\end{array}$ & & & & & & 7/20/98 - 7/28/98 & $1.9-2.0 \mathrm{bb} / \mathrm{min}$ & $1,000-1,400$ & annular \\
\hline India/Panna Field/STC2 & $\begin{array}{l}\text { Enron Oil \& } \\
\text { Gas India Ltd. }\end{array}$ & Apollo Services (2002) & $\begin{array}{l}\text { Apollo } \\
\text { Services } \\
\end{array}$ & & & & & & $12 / 24 / 98-12 / 31 / 98$ & $1.6 \mathrm{bbl} / \mathrm{min}$ & $\begin{array}{l}1,200-1,500 \\
\text { psi }\end{array}$ & annular \\
\hline India/Panna Field/STC3 & $\begin{array}{l}\text { Enron Oil \& } \\
\text { Gas India Ltd. }\end{array}$ & Apollo Services (2002) & $\begin{array}{l}\text { Apollo } \\
\text { Services }\end{array}$ & & & & & & $12 / 1 / 98-12 / 23 / 98$ & $1.6-2.3 \mathrm{bbl} / \mathrm{min}$ & $\begin{array}{l}1,100-1,850 \\
\text { psi }\end{array}$ & annular \\
\hline India/Panna Field/STC4 & $\begin{array}{l}\text { Enron Oil \& } \\
\text { Gas India Ltd. }\end{array}$ & Apollo Services (2002) & $\begin{array}{l}\text { Apollo } \\
\text { Services }\end{array}$ & & & & & & $12 / 7 / 98-12 / 14 / 98$ & $1.6-2.1 \mathrm{bbl} / \mathrm{min}$ & $\begin{array}{l}1,125-1,400 \\
\text { psi }\end{array}$ & annular \\
\hline $\begin{array}{l}\text { India/South Tapia } \\
\text { Field/STB5 }\end{array}$ & $\begin{array}{l}\text { Enron Oil \& } \\
\text { Gas India Ltd. }\end{array}$ & Apollo Services (2002) & $\begin{array}{l}\text { Apollo } \\
\text { Services }\end{array}$ & & & & & & & & & annular \\
\hline $\begin{array}{l}\text { India/South Tapia } \\
\text { Field/STB6 }\end{array}$ & $\begin{array}{l}\text { Enron Oil \& } \\
\text { Gas India Ltd. }\end{array}$ & Apollo Services (2002) & $\begin{array}{l}\text { Apollo } \\
\text { Services }\end{array}$ & & & & & & & & & annular \\
\hline Indonesia/ Sumatra/Duri & $\begin{array}{l}\text { Caltex Pacific } \\
\text { Indonesia } \\
\end{array}$ & Bilak et al. (2002) & $\begin{array}{l}\text { Terralog } \\
\text { Technologies } \\
\end{array}$ & $\begin{array}{l}\text { Dalam and Pematang } \\
\text { formations; porous, } \\
\text { unconsolidated with } \\
\text { alternating sand and shale } \\
\text { layers }\end{array}$ & $\begin{array}{l}\text { Dalam - 1,060'- } \\
1,300^{\prime} ; \text { Pematang } \\
-1,300^{\prime}-1,700^{\prime} \\
\end{array}$ & $\begin{array}{l}\text { Dalam - 1,246'- } \\
1,276^{\prime}\end{array}$ & $\begin{array}{l}\text { Kedua and } \\
\text { Katama } \\
\text { formations } \\
\text { overlie Dalam; } \\
\text { they are similar } \\
\text { to Dalam in } \\
\text { characteristics } \\
\end{array}$ & & $\begin{array}{l}\text { pilot test conducted } \\
\text { from } 11 / 24 / 00- \\
12 / 5 / 00 ; \text { full scale } \\
\text { operations scheduled } \\
\text { to begin } 6 / 02 ; \\
\text { anticipate operations } \\
\text { up to } 20 \text { hours/day } \\
\text { and } 25 \text { days/month } \\
\end{array}$ & $12-15 \mathrm{bbl} / \mathrm{min}$ & $\begin{array}{l}1,200-1,400 \\
\text { psi BHP }\end{array}$ & \\
\hline
\end{tabular}




\begin{tabular}{|c|c|c|c|c|c|c|c|}
\hline Site Location/Name & Type of Waste Injected & $\begin{array}{l}\text { Volume of } \\
\text { Material } \\
\text { Injected } \\
\end{array}$ & $\begin{array}{l}\text { Slurry } \\
\text { Properties } \\
\text { (fluid, } \\
\text { density) } \\
\end{array}$ & $\begin{array}{l}\text { Pre-Injection } \\
\text { Processing/ } \\
\text { Treatment }\end{array}$ & Problems Experienced & Costs & Other Comments \\
\hline \begin{tabular}{|l} 
Gulf of Mexico/West \\
Cameron $174 /$ OCSG 17766
\end{tabular} & cuttings & 1,852 bbl slurry & & & & & $\begin{array}{l}\text { limited data provided } \\
\text { for this job }\end{array}$ \\
\hline $\begin{array}{l}\text { Gulf of Mexico/West } \\
\text { Cameron } 196 / \mathrm{A}-10\end{array}$ & cuttings & 5,830 bbl slurry & $8.6-10.2 \mathrm{lb} / \mathrm{gal}$ & $\begin{array}{l}\text { Prologic } \\
\text { (viscosifer) }\end{array}$ & & & $\begin{array}{l}\text { limited data provided } \\
\text { for this job }\end{array}$ \\
\hline \begin{tabular}{|l} 
Gulf of Mexico/West \\
Cameron 196/A-11
\end{tabular} & cuttings & 6,408 bbl slurry & $8.4-10.4 \mathrm{lb} / \mathrm{gal}$ & $\begin{array}{l}\text { Prologic } \\
\text { (viscosifer) }\end{array}$ & & & $\begin{array}{l}\text { limited data provided } \\
\text { for this job }\end{array}$ \\
\hline $\begin{array}{l}\text { Gulf of Mexico/West } \\
\text { Cameron 196/A-12 }\end{array}$ & cuttings & 5,992 bbl slurry & $8.8-10.0 \mathrm{lb} / \mathrm{gal}$ & $\begin{array}{l}\text { Prologic } \\
\text { (viscosifer) }\end{array}$ & & & $\begin{array}{l}\text { limited data provided } \\
\text { for this job }\end{array}$ \\
\hline $\begin{array}{l}\text { Gulf of Mexico/West } \\
\text { Cameron 196/A-9 }\end{array}$ & cuttings & 23354 bbl slurry & $8.6-11.3 \mathrm{lb} / \mathrm{gal}$ & & & & $\begin{array}{l}\text { limited data provided } \\
\text { for this job }\end{array}$ \\
\hline $\begin{array}{l}\text { Gulf of Mexico/West } \\
\text { Cameron 280/B-5 } \\
\end{array}$ & cuttings & 13,434 bbl slurry & $8.7-10.5 \mathrm{lb} / \mathrm{gal}$ & & & & $\begin{array}{l}\text { limited data provided } \\
\text { for this job }\end{array}$ \\
\hline \begin{tabular}{|l} 
Gulf of Mexico/West \\
Cameron 280/OCSG 15074
\end{tabular} & cuttings & 17,516 bbl slurry & & & & & $\begin{array}{l}\text { limited data provided } \\
\text { for this job }\end{array}$ \\
\hline $\begin{array}{l}\text { Gulf of Mexico/West } \\
\text { Cameron 53/OCSG } 4379\end{array}$ & cuttings & 11,086 bbl slurry & & & & & $\begin{array}{l}\text { limited data provided } \\
\text { for this job }\end{array}$ \\
\hline India/Panna Field/PC4 & cuttings & 3,950 bbl slurry & & & & & $\begin{array}{l}\text { limited data provided } \\
\text { for this job }\end{array}$ \\
\hline India/Panna Field/PC5 & cuttings & 4,131 bbl slurry & & & & & $\begin{array}{l}\text { limited data provided } \\
\text { for this job }\end{array}$ \\
\hline India/Panna Field/PC6 & cuttings & 7,724 bbl slurry & $8.5-9.9 \mathrm{lb} / \mathrm{gal}$ & & & & $\begin{array}{l}\text { limited data provided } \\
\text { for this job }\end{array}$ \\
\hline India/Panna Field/PC8 & cuttings & 5,653 bbl slurry & & & & & $\begin{array}{l}\text { limited data provided } \\
\text { for this job }\end{array}$ \\
\hline India/Panna Field/PF10 & cuttings & 6,385 bbl slurry & $9.9-10.8 \mathrm{lb} / \mathrm{gal}$ & & & & $\begin{array}{l}\text { limited data provided } \\
\text { for this job }\end{array}$ \\
\hline India/Panna Field/PF11 & cuttings & 14,107 bbl slurry & $\begin{array}{l}10.1-10.7 \\
\text { lb/gal }\end{array}$ & & & & $\begin{array}{l}\text { limited data provided } \\
\text { for this job }\end{array}$ \\
\hline India/Panna Field/PF12 & cuttings & 13,506 bbl slurry & $9.3-9.7 \mathrm{lb} / \mathrm{gal}$ & & & & $\begin{array}{l}\text { limited data provided } \\
\text { for this job }\end{array}$ \\
\hline India/Panna Field/PF14-H & cuttings & 20,385 bbl slurry & $8.7-10.4 \mathrm{lb} / \mathrm{gal}$ & & & & $\begin{array}{l}\text { limited data provided } \\
\text { for this job }\end{array}$ \\
\hline India/Panna Field/PF3 & cuttings & 8,141 bbl slurry & $9.6-9.7 \mathrm{lb} / \mathrm{gal}$ & & & & $\begin{array}{l}\text { limited data provided } \\
\text { for this job }\end{array}$ \\
\hline India/Panna Field/PF5 & cuttings & 3,745 bbl slurry & $9.9-11.0 \mathrm{lb} / \mathrm{gal}$ & & & & $\begin{array}{l}\text { limited data provided } \\
\text { for this job }\end{array}$ \\
\hline India/Panna Field/PF6 & cuttings & 18,858 bbl slurry & $\begin{array}{l}10.0-10.5 \\
\text { lb/gal }\end{array}$ & & & & $\begin{array}{l}\text { limited data provided } \\
\text { for this job }\end{array}$ \\
\hline India/Panna Field/PF8 & cuttings & 3,483 bbl slurry & $9.6-10.2 \mathrm{lb} / \mathrm{gal}$ & & & & $\begin{array}{l}\text { limited data provided } \\
\text { for this job }\end{array}$ \\
\hline India/Panna Field/STC2 & cuttings & 2,592 bbl slurry & $9.8-10.9 \mathrm{lb} / \mathrm{gal}$ & & & & $\begin{array}{l}\text { limited data provided } \\
\text { for this job }\end{array}$ \\
\hline India/Panna Field/STC3 & cuttings & 8,650 bbl slurry & $9.1-10.4 \mathrm{lb} / \mathrm{gal}$ & & & & $\begin{array}{l}\text { limited data provided } \\
\text { for this job }\end{array}$ \\
\hline India/Panna Field/STC4 & cuttings & 5,279 bbl slurry & $9.7-10.1 \mathrm{lb} / \mathrm{gal}$ & & & & $\begin{array}{l}\text { limited data provided } \\
\text { for this job }\end{array}$ \\
\hline $\begin{array}{l}\text { India/South Tapia } \\
\text { Field/STB5 }\end{array}$ & cuttings & 19,450 bbl slurry & & & & & $\begin{array}{l}\text { limited data provided } \\
\text { for this job }\end{array}$ \\
\hline $\begin{array}{l}\text { India/South Tapia } \\
\text { Field/STB6 } \\
\end{array}$ & cuttings & 11,784 bbl slurry & & & & & $\begin{array}{l}\text { limited data provided } \\
\text { for this job }\end{array}$ \\
\hline Indonesia/ Sumatra/Duri & $\begin{array}{l}\text { pilot test used sand/water } \\
\text { and sand/water/oily slop } \\
\text { mixtures; injection well will } \\
\text { be used for disposal of } \\
\text { produced water, produced } \\
\text { solids, tank bottoms, and } \\
\text { oily viscous fluids from the } \\
\text { Central Gathering Stations } \\
\text { site } \\
\end{array}$ & $\begin{array}{l}\text { design volumes } \\
\text { are } 3,150 \\
\text { bbl/day solids } \\
\text { mixed with } \\
; 19,000 \text { bbl/day } \\
\text { of water }\end{array}$ & $\begin{array}{l}\text { may be } \\
\text { produced } \\
\text { water, waste } \\
\text { brine, or well } \\
\text { workover fluids } \\
\end{array}$ & $\begin{array}{l}\text { settling tanks, } \\
\text { hydrocyclones, } \\
\text { screens }\end{array}$ & & & \\
\hline
\end{tabular}




\begin{tabular}{|c|c|c|c|c|c|c|c|c|c|c|c|c|}
\hline Site Location/Name & $\begin{array}{l}\text { Operator } \\
\text { Generating } \\
\text { Wastes }\end{array}$ & Source of Information & $\begin{array}{l}\text { Service } \\
\text { Company } \\
\text { Doing } \\
\text { Injection } \\
\end{array}$ & $\begin{array}{l}\text { Geology of Injection } \\
\text { Zone (type of rock, } \\
\text { porosity, permeability) }\end{array}$ & $\begin{array}{l}\text { Depth of } \\
\text { Injection Zone }\end{array}$ & $\begin{array}{l}\text { Depth of } \\
\text { Perforations/ } \\
\text { annular } \\
\text { Injection }\end{array}$ & $\begin{array}{l}\text { Geology and } \\
\text { Depth of } \\
\text { Confining } \\
\text { Layer }\end{array}$ & $\begin{array}{l}\text { Other } \\
\text { Geological } \\
\text { Information }\end{array}$ & $\begin{array}{l}\text { Dates and Duration } \\
\text { of Injection }\end{array}$ & Injection Rate & $\begin{array}{l}\text { Injection } \\
\text { Pressure }\end{array}$ & $\begin{array}{l}\text { Type of } \\
\text { Injection }\end{array}$ \\
\hline $\begin{array}{l}\text { Louisiana } \\
\text { onshore/Acadia/Raymond\#1 }\end{array}$ & 1 Hunt Oil & Apollo Services (2002) & $\begin{array}{l}\text { Apollo } \\
\text { Services }\end{array}$ & & & & & & & & & annular \\
\hline Louisiana onshore/ASI & $\mathrm{COHO}$ & Apollo Services (2002) & $\begin{array}{l}\text { Apollo } \\
\text { Services }\end{array}$ & & & & & & & & & annular \\
\hline $\begin{array}{l}\text { Louisiana onshore/Baton } \\
\text { Rouge/\#2 }\end{array}$ & Seagull & Apollo Services (2002) & $\begin{array}{l}\text { Apollo } \\
\text { Services }\end{array}$ & & & & & & & & & annular \\
\hline $\begin{array}{l}\text { Louisiana onshore/Baton } \\
\text { Rouge/Baxter \#1 }\end{array}$ & JN Exploration & Apollo Services (2002) & $\begin{array}{l}\text { Apollo } \\
\text { Services }\end{array}$ & & & & & & & & & annular \\
\hline $\begin{array}{l}\text { Louisiana } \\
\text { onshore/Cameron/Amoco } \\
\text { Fee \#1 }\end{array}$ & Hunt Oil & Apollo Services (2002) & $\begin{array}{l}\text { Apollo } \\
\text { Services }\end{array}$ & & & & & & & & & annular \\
\hline $\begin{array}{l}\text { Louisiana } \\
\text { onshore/Cameron/Cox\#1 }\end{array}$ & Hunt Oil & Apollo Services (2002) & $\begin{array}{l}\text { Apollo } \\
\text { Services }\end{array}$ & & & & & & & & & annular \\
\hline $\begin{array}{l}\text { Louisiana } \\
\text { onshore/Cameron/Sweet } \\
\text { Lake \#1 }\end{array}$ & Hunt Oil & Apollo Services (2002) & $\begin{array}{l}\text { Apollo } \\
\text { Services }\end{array}$ & & & & & & & & & annular \\
\hline $\begin{array}{l}\text { Louisiana } \\
\text { onshore/Cassinade/Nolia } \\
\text { Landry \#2 }\end{array}$ & Hunt Oil & Apollo Services (2002) & $\begin{array}{l}\text { Apollo } \\
\text { Services }\end{array}$ & & & & & & & & & annular \\
\hline $\begin{array}{l}\text { Louisiana onshore/Des } \\
\text { Almonds/SL2670/\#1 }\end{array}$ & WRT & Apollo Services (2002) & $\begin{array}{l}\text { Apollo } \\
\text { Services }\end{array}$ & & & & & & & & & annular \\
\hline $\begin{array}{l}\text { Louisiana onshore/Des } \\
\text { Almonds/SL2670/\#2 }\end{array}$ & WRT & Apollo Services (2002) & $\begin{array}{l}\text { Apollo } \\
\text { Services }\end{array}$ & & & & & & & & & annular \\
\hline $\begin{array}{l}\text { Louisiana } \\
\text { onshore/Duson/NC-1 }\end{array}$ & Unocal & Apollo Services (2002) & $\begin{array}{l}\text { Apollo } \\
\text { Services }\end{array}$ & & & $15,300^{\prime}$ & & & $5 / 28 / 01-7 / 21 / 01$ & $1.0-3.6 \mathrm{bbl} / \mathrm{min}$ & $50-658 \mathrm{psi}$ & annular \\
\hline Louisiana onshore/Etal \#1 & Great Western & Apollo Services (2002) & $\begin{array}{l}\text { Apollo } \\
\text { Services }\end{array}$ & & & & & & & & & annular \\
\hline $\begin{array}{l}\text { Louisiana onshore/Holly } \\
\text { Beach/OCS-G }\end{array}$ & Chevron & Apollo Services (2002) & $\begin{array}{l}\text { Apollo } \\
\text { Services }\end{array}$ & & & & & & & & & annular \\
\hline Louisiana onshore/Lockport & Stone & Apollo Services (2002) & $\begin{array}{l}\text { Apollo } \\
\text { Services }\end{array}$ & & & & & & & & & annular \\
\hline $\begin{array}{l}\text { Louisiana onshore/South } \\
\text { Gueydun/Cherry Ridge \#1 }\end{array}$ & PEI & Apollo Services (2002) & $\begin{array}{l}\text { Apollo } \\
\text { Services }\end{array}$ & & & & & & & & & annular \\
\hline $\begin{array}{l}\text { Louisiana } \\
\text { onshore/Terrebonne/Cox\#2 }\end{array}$ & Kelly Oil & Apollo Services (2002) & $\begin{array}{l}\text { Apollo } \\
\text { Services }\end{array}$ & & & & & & & & & annular \\
\hline $\begin{array}{l}\text { Louisiana } \\
\text { onshore/Vermillion/Nolia } \\
\text { Landry \#1 }\end{array}$ & Hunt Oil & Apollo Services (2002) & $\begin{array}{l}\text { Apollo } \\
\text { Services }\end{array}$ & & & & & & & & & annular \\
\hline $\begin{array}{l}\text { Louisiana } \\
\text { onshore/Vermillion/Sarver } \\
\# 1\end{array}$ & Hunt Oil & Apollo Services (2002) & $\begin{array}{l}\text { Apollo } \\
\text { Services }\end{array}$ & & & & & & & & & annular \\
\hline Louisiana onshore/Wilcox \#1 & 1E.P. Operating & Apollo Services (2002) & $\begin{array}{l}\text { Apollo } \\
\text { Services }\end{array}$ & & & & & & & & & annular \\
\hline $\begin{array}{l}\text { Louisiana/Port } \\
\text { Fourchon/CNO \#2 }\end{array}$ & Chevron & $\begin{array}{l}\text { Baker et al. (1999a,b); Reed } \\
\text { et al. (2001); Terralog (2001, } \\
\text { 2002b) }\end{array}$ & $\begin{array}{l}\text { Terralog } \\
\text { Technologies } \\
\text { designed the } \\
\text { operations; } \\
\text { Superior did } \\
\text { the injection }\end{array}$ & $\begin{array}{l}\text { alternating sandstone and } \\
\text { shale layers; two different } \\
\text { injection zones } \\
\text { (Completions \#1 and \#2) in } \\
\text { sandy layers; permeability } \\
200-14,000 \mathrm{md} \text { (mostly } \\
500-2,000 \mathrm{md}) ; \text { porosity } \\
0.23\end{array}$ & $3,880^{\prime}-5,000^{\prime}$ & $\begin{array}{l}\text { completion \#1 - } \\
4,960^{\prime}-5,000^{\prime} ; \\
\text { completion \#2 - } \\
4,520^{\prime}-4,560^{\prime}\end{array}$ & $\begin{array}{l}\text { shale layer from } \\
2,650^{\prime}-3,250^{\prime}\end{array}$ & & $\begin{array}{l}\text { 6/98 - 9/98; 2/99 - } \\
3 / 20 ; \text { injection for } 9- \\
11 \text { hours/day, five } \\
\text { days/week; daily } \\
\text { injection cycles } \\
\text { followed by relaxation } \\
\text { of pressure for } 13-15 \\
\text { hours }\end{array}$ & $8-16 \mathrm{bbl} / \mathrm{min}$ & $\begin{array}{l}\text { completion } \\
\# 1 \text { - } 3,580- \\
3,940 \text { psi; } \\
\text { completion } \\
\# 2-3,350- \\
3,700 \text { psi } \\
\end{array}$ & $\begin{array}{l}\text { tubing and } \\
\text { packer }\end{array}$ \\
\hline Mexico/Del Carmen & PEI-Sonat & Apollo Services (2002) & $\begin{array}{l}\text { Apollo } \\
\text { Services }\end{array}$ & & & & & & & & & annular \\
\hline
\end{tabular}




\begin{tabular}{|c|c|c|c|c|c|c|c|}
\hline Site Location/Name & Type of Waste Injected & $\begin{array}{l}\text { Volume of } \\
\text { Material } \\
\text { Injected }\end{array}$ & $\begin{array}{l}\text { Slurry } \\
\text { Properties } \\
\text { (fluid, } \\
\text { density) } \\
\end{array}$ & $\begin{array}{l}\text { Pre-Injection } \\
\text { Processing/ } \\
\text { Treatment }\end{array}$ & Problems Experienced & Costs & Other Comments \\
\hline $\begin{array}{l}\text { Louisiana } \\
\text { onshore/Acadia/Raymond\#1 }\end{array}$ & cuttings & 42,777 bbl slurry & & & & & $\begin{array}{l}\text { limited data provided } \\
\text { for this job }\end{array}$ \\
\hline Louisiana onshore/ASI & cuttings & $12,486 \mathrm{bbl}$ slurry & & & & & $\begin{array}{l}\text { limited data provided } \\
\text { for this job }\end{array}$ \\
\hline $\begin{array}{l}\text { Louisiana onshore/Baton } \\
\text { Rouge/\#2 }\end{array}$ & cuttings & 38,976 bbl slurry & & & & & $\begin{array}{l}\text { limited data provided } \\
\text { for this job }\end{array}$ \\
\hline $\begin{array}{l}\text { Louisiana onshore/Baton } \\
\text { Rouge/Baxter\#1 }\end{array}$ & cuttings & 685 bbl slurry & & & & & $\begin{array}{l}\text { limited data provided } \\
\text { for this job }\end{array}$ \\
\hline $\begin{array}{l}\text { Louisiana } \\
\text { onshore/Cameron/Amoco } \\
\text { Fee \#1 }\end{array}$ & cuttings & $56,250 \mathrm{bbl}$ slurry & & & & & $\begin{array}{l}\text { limited data provided } \\
\text { for this job }\end{array}$ \\
\hline $\begin{array}{l}\text { Louisiana } \\
\text { onshore/Cameron/Cox \#1 }\end{array}$ & cuttings & 44,129 bbl slurry & & & & & $\begin{array}{l}\text { limited data provided } \\
\text { for this job }\end{array}$ \\
\hline $\begin{array}{l}\text { Louisiana } \\
\text { onshore/Cameron/Sweet } \\
\text { Lake \#1 }\end{array}$ & cuttings & 31,258 bbl slurry & & & & & $\begin{array}{l}\text { limited data provided } \\
\text { for this job }\end{array}$ \\
\hline $\begin{array}{l}\text { Louisiana } \\
\text { onshore/Cassinade/Nolia } \\
\text { Landry \#2 }\end{array}$ & cuttings & $\begin{array}{l}154,083 \mathrm{bbl} \\
\text { slurry }\end{array}$ & & & & & $\begin{array}{l}\text { limited data provided } \\
\text { for this job }\end{array}$ \\
\hline $\begin{array}{l}\text { Louisiana onshore/Des } \\
\text { Almonds/SL2670/\#1 }\end{array}$ & cuttings & 450 bbl slurry & & & & & $\begin{array}{l}\text { limited data provided } \\
\text { for this job }\end{array}$ \\
\hline $\begin{array}{l}\text { Louisiana onshore/Des } \\
\text { Almonds/SL2670/\#2 }\end{array}$ & cuttings & 326 bbl slurry & & & & & $\begin{array}{l}\text { limited data provided } \\
\text { for this job }\end{array}$ \\
\hline \begin{tabular}{|l|} 
Louisiana \\
onshore/Duson/NC-1
\end{tabular} & cuttings & $5,120 \mathrm{bbl}$ slurry & 8.4-18.4 Ib/gal & & & & $\begin{array}{l}\text { limited data provided } \\
\text { for this job }\end{array}$ \\
\hline Louisiana onshore/Etal \#1 & cuttings & 18,476 bbl slurry & & & & & $\begin{array}{l}\text { limited data provided } \\
\text { for this job }\end{array}$ \\
\hline $\begin{array}{l}\text { Louisiana onshore/Holly } \\
\text { Beach/OCS-G }\end{array}$ & cuttings & $13,639 \mathrm{bbl}$ slurry & & & & & $\begin{array}{l}\text { limited data provided } \\
\text { for this job }\end{array}$ \\
\hline Louisiana onshore/Lockport & NORM & 5,245 bbl slurry & & & & & $\begin{array}{l}\text { limited data provided } \\
\text { for this job }\end{array}$ \\
\hline $\begin{array}{l}\text { Louisiana onshore/South } \\
\text { Gueydun/Cherry Ridge \#1 }\end{array}$ & cuttings & 18,462 bbl slurry & & & & & $\begin{array}{l}\text { limited data provided } \\
\text { for this job }\end{array}$ \\
\hline $\begin{array}{l}\text { Louisiana } \\
\text { onshore/Terrebonne/Cox \#2 }\end{array}$ & cuttings & 85,923 bbl slurry & & & & & $\begin{array}{l}\text { limited data provided } \\
\text { for this job }\end{array}$ \\
\hline $\begin{array}{l}\text { Louisiana } \\
\text { onshore/Vermillion/Nolia } \\
\text { Landry \#1 }\end{array}$ & cuttings & 67,532 bbl slurry & & & & & $\begin{array}{l}\text { limited data provided } \\
\text { for this job }\end{array}$ \\
\hline $\begin{array}{l}\text { Louisiana } \\
\text { onshore/Vermillion/Sarver } \\
\# 1\end{array}$ & cuttings & 39,843 bbl slurry & & & & & $\begin{array}{l}\text { limited data provided } \\
\text { for this job }\end{array}$ \\
\hline Louisiana onshore/Wilcox\#1 & 1 cuttings & 28,320 bbl slurry & & & & & $\begin{array}{l}\text { limited data provided } \\
\text { for this job }\end{array}$ \\
\hline \begin{tabular}{|l} 
Louisiana/Port \\
Fourchon/CNO \#2
\end{tabular} & $\begin{array}{l}\text { pit contents (contains drill } \\
\text { cuttings, drilling muds, } \\
\text { produced sand, salt water, } \\
\text { pipe scale, crude oil), } \\
\text { canal bottom sediments, } \\
\text { tank bottoms, produced } \\
\text { water; these contained } \\
\text { NORM }\end{array}$ & $\begin{array}{l}1,000,800 \text { bbl of } \\
\text { solids contained } \\
\text { in } 2,949,700 \text { bbl } \\
\text { slurry }\end{array}$ & $\begin{array}{l}\text { water from the } \\
\text { nearby canal } \\
\text { was used to } \\
\text { make a slurry } \\
\text { containing 20- } \\
70 \% \text { solids }\end{array}$ & $\begin{array}{l}\text { solids were } \\
\text { screened to } \\
\text { remove large } \\
\text { materials; } \\
\text { centrifugal pumps } \\
\text { used to reduce } \\
\text { particle size }\end{array}$ & $\begin{array}{l}\text { poor cement bonds around } \\
\text { completion \#1 allowed fluids } \\
\text { to move upward along the } \\
\text { wellbore; this resulted in } \\
\text { excessive pressure in a thin } \\
\text { sand layer at 4,614'; the } \\
\text { layer sheared and damaged } \\
\text { the casing, thereby } \\
\text { necessitating completion \#2 }\end{array}$ & $\begin{array}{l}\text { total cost was } \\
\sim \$ 19 / \text { bbl; the } \\
\text { cost attributable } \\
\text { to the injection } \\
\text { process was } \\
\sim \$ 11 / \text { bbl }\end{array}$ & $\begin{array}{l}\text { multiple injection/res } \\
\text { cycles allowed for a } \\
\text { large volume of } \\
\text { waste to be injected; } \\
722,000 \text { bbl injected } \\
\text { through completion } \\
\text { \#2 was believed to } \\
\text { have filled a waste } \\
\text { pod } 80 \text { ' thick and a } \\
\text { max. half-length of } \\
1,450 ' \text {; listed in } \\
\text { Terralog (2002b) as } \\
\text { projects TTI10 and } \\
\text { TTI11 }\end{array}$ \\
\hline Mexico/Del Carmen & cuttings & $\begin{array}{l}5 \text { jobs totaling } \\
43,000 \text { bbl slurry }\end{array}$ & & & & & $\begin{array}{l}\text { limited data provided } \\
\text { for this job }\end{array}$ \\
\hline
\end{tabular}




\begin{tabular}{|c|c|c|c|c|c|c|c|c|c|c|c|c|}
\hline Site Location/Name & $\begin{array}{l}\text { Operator } \\
\text { Generating } \\
\text { Wastes } \\
\end{array}$ & Source of Information & $\begin{array}{l}\text { Service } \\
\text { Company } \\
\text { Doing } \\
\text { Injection } \\
\end{array}$ & $\begin{array}{l}\text { Geology of Injection } \\
\text { Zone (type of rock, } \\
\text { porosity, permeability) }\end{array}$ & $\begin{array}{l}\text { Depth of } \\
\text { Injection Zone }\end{array}$ & $\begin{array}{l}\text { Depth of } \\
\text { Perforations/ } \\
\text { annular } \\
\text { Injection } \\
\end{array}$ & $\begin{array}{l}\text { Geology and } \\
\text { Depth of } \\
\text { Confining } \\
\text { Layer }\end{array}$ & $\begin{array}{l}\text { Other } \\
\text { Geological } \\
\text { Information }\end{array}$ & $\begin{array}{l}\text { Dates and Duration } \\
\text { of Injection }\end{array}$ & Injection Rate & $\begin{array}{l}\text { Injection } \\
\text { Pressure }\end{array}$ & $\begin{array}{l}\text { Type of } \\
\text { Injection }\end{array}$ \\
\hline Mexico/King Ridge/\#1 & PEI-Quintana & Apollo Services (2002) & $\begin{array}{l}\text { Apollo } \\
\text { Services }\end{array}$ & & & & & & & & & annular \\
\hline $\begin{array}{l}\text { North Carolina onshore/ } \\
2714 \mathrm{H}\end{array}$ & Amerada Hess & Apollo Services (2002) & $\begin{array}{l}\text { Apollo } \\
\text { Services }\end{array}$ & & & & & & & & & annular \\
\hline $\begin{array}{l}\text { North Sea/Norway/Asgard } \\
\text { (9 different wells) }\end{array}$ & Statoil & Saasen et al. (2001) & & $\begin{array}{l}\text { Tertiary mudstone in } \\
\text { Nordland Group }\end{array}$ & $\begin{array}{l}\text { similar to Asgard } \\
\mathrm{K}-2 \mathrm{H}\end{array}$ & $\begin{array}{l}\text { injection is into } \\
\text { the } 20 " \text { by } 13-3 / 8 " \\
\text { annulus; } 20 " \\
\text { casing shoe is } \\
\text { set at various } \\
\text { depths, not all } \\
\text { are specified } \\
\end{array}$ & not specified & & $\begin{array}{l}\text { not specified; but } \\
\text { prior to the end of } \\
2000\end{array}$ & $\begin{array}{l}\text { not specified; in } \\
\text { some later } \\
\text { wells, injection } \\
\text { was done in } \\
\text { batches not to } \\
\text { exceed } 1,570 \\
\text { bcl, followed by } \\
\text { at least } 24 \\
\text { hours without } \\
\text { pumping }\end{array}$ & $\begin{array}{l}\text { not } \\
\text { specified }\end{array}$ & annular \\
\hline North Sea/Brae Bravo & & MI/SWACO (2002) & MI/SWACO & & & & & & $1 / 93-12 / 01$ & & & annular \\
\hline North Sea/Bruce & $\mathrm{BP}$ & MI/SWACO (2002) & MI/SWACO & & & & & & $1 / 93-12 / 01$ & & & annular \\
\hline North Sea/Dunlin & Shell & MI/SWACO (2002) & MI/SWACO & & & & & & $1 / 93-12 / 01$ & & & annular \\
\hline North Sea/Harding & $\mathrm{BP}$ & MI/SWACO (2002) & MI/SWACO & & & & & & $1 / 93-12 / 01$ & & & annular \\
\hline North Sea/Judy & & MI/SWACO (2002) & MI/SWACO & & & & & & $1 / 93-12 / 01$ & & & annular \\
\hline North Sea/Magnus & BP & MI/SWACO (2002) & MI/SWACO & & & & & & $1 / 93-12 / 01$ & & & annular \\
\hline North Sea/North Comorant & Shell & MI/SWACO (2002) & MI/SWACO & & & & & & $1 / 93-12 / 01$ & & & annular \\
\hline $\begin{array}{l}\text { North Sea/Norway/ } \\
\text { Ekofisk/2/4X }\end{array}$ & Phillips & $\begin{array}{l}\text { Nagel and Strachan (1998); } \\
\text { James and Rørvik (2002) }\end{array}$ & & $\begin{array}{l}\text { Hordaland Group (shales } \\
\text { and claystones) }\end{array}$ & $6,000^{\prime}-6,800^{\prime}$ & not specified & $\begin{array}{l}\text { Nordland group } \\
\text { (sand, claystone, } \\
\text { limestone) }\end{array}$ & $\begin{array}{l}\text { injection well } \\
\text { positioned at the } \\
\text { flank of the } \\
\text { producing } \\
\text { reservoir }\end{array}$ & $\begin{array}{l}12 / 96-4 / 97 \\
\text { (continued after that } \\
\text { time) }\end{array}$ & not specified & $\begin{array}{l}2,750-3,250 \\
\text { psi }\end{array}$ & $\begin{array}{l}\text { tubing and } \\
\text { packer }\end{array}$ \\
\hline $\begin{array}{l}\text { North Sea/Norway/ Eldfisk } \\
\text { 2/7A-08 }\end{array}$ & Phillips & James and Rørvik (2002) & & $\begin{array}{l}\text { Hordaland Group (shales } \\
\text { and claystones) }\end{array}$ & $6,000^{\prime}-6,800^{\prime}$ & $\sim 6,800^{\prime}$ & $\begin{array}{l}\begin{array}{l}\text { Nordland group } \\
\text { (sand, claystone, } \\
\text { limestone) }\end{array} \\
\end{array}$ & & & & & $\begin{array}{l}\text { tubing and } \\
\text { packer }\end{array}$ \\
\hline
\end{tabular}




\begin{tabular}{|c|c|c|c|c|c|c|c|}
\hline Site Location/Name & Type of Waste Injected & $\begin{array}{l}\text { Volume of } \\
\text { Material } \\
\text { Injected } \\
\end{array}$ & $\begin{array}{l}\text { Slurry } \\
\text { Properties } \\
\text { (fluid, } \\
\text { density) } \\
\end{array}$ & $\begin{array}{l}\text { Pre-Injection } \\
\text { Processing/ } \\
\text { Treatment }\end{array}$ & Problems Experienced & Costs & Other Comments \\
\hline Mexico/King Ridge/\#1 & cuttings & 23,773 bbl slurry & & & & & $\begin{array}{l}\text { limited data provided } \\
\text { for this job }\end{array}$ \\
\hline $\begin{array}{l}\text { North Carolina onshore/ } \\
2714 \mathrm{H}\end{array}$ & cuttings & 48,452 bbl slurry & & & & & $\begin{array}{l}\text { limited data provided } \\
\text { for this job }\end{array}$ \\
\hline $\begin{array}{l}\text { North Sea/Norway/Asgard } \\
\text { (9 different wells) }\end{array}$ & oily cuttings, slop water & $\begin{array}{l}\text { total for } 9 \text { wells: } \\
55,000 \text { bbl } \\
\text { cuttings, } 18,000 \\
\text { bbl slop, } 95,000 \\
\text { total injectate } \\
\end{array}$ & $\begin{array}{l}\text { density } \sim 1.30 \\
\text { SG; seawater } \\
\text { used as fluid }\end{array}$ & crushing mill & $\begin{array}{l}\text { several wells showed } \\
\text { leakage at the sea floor; this } \\
\text { was presumed to be due to } \\
\text { poor cementing jobs; in } \\
\text { some wells, the leakage } \\
\text { stopped after letting } \\
\text { fractures heal over-- in other } \\
\text { wells, injection was } \\
\text { discontinued; other } \\
\text { problems were caused by } \\
\text { drilling into shallow gas } \\
\text { zones and having to drill } \\
\text { some side tracks }\end{array}$ & & $\begin{array}{l}\text { this points out the } \\
\text { problems of injecting } \\
\text { into formations } \\
\text { without nearby sand } \\
\text { layers to allow fluids } \\
\text { to leak off; Statoil } \\
\text { developed new } \\
\text { cementing } \\
\text { techniques and } \\
\text { batch injection to } \\
\text { overcome problems } \\
\end{array}$ \\
\hline North Sea/Brae Bravo & oil-based cuttings & $53,369 \mathrm{bbl}$ & & & & & $\begin{array}{l}\text { same as } \\
\text { Alaska/North } \\
\text { Slope/Alpine }\end{array}$ \\
\hline North Sea/Bruce & oil-based cuttings & $43,188 \mathrm{bbl}$ & & & & & $\begin{array}{l}\text { same as } \\
\text { Alaska/North } \\
\text { Slope/Alpine }\end{array}$ \\
\hline North Sea/Dunlin & oil-based cuttings & $7,076 \mathrm{bbl}$ & & & & & $\begin{array}{l}\text { same as } \\
\text { Alaska/North } \\
\text { Slope/Alpine }\end{array}$ \\
\hline North Sea/Harding & oil-based cuttings & $241,739 \mathrm{bbl}$ & & & & & $\begin{array}{l}\text { same as } \\
\text { Alaska/North } \\
\text { Slope/Alpine }\end{array}$ \\
\hline North Sea/Judy & oil-based cuttings & $9,998 \mathrm{bbl}$ & & & & & $\begin{array}{l}\text { same as } \\
\text { Alaska/North } \\
\text { Slope/Alpine }\end{array}$ \\
\hline North Sea/Magnus & oil-based cuttings & $83,031 \mathrm{bbl}$ & & & & & $\begin{array}{l}\text { same as } \\
\text { Alaska/North } \\
\text { Slope/Alpine }\end{array}$ \\
\hline North Sea/North Comorant & oil-based cuttings & $81,947 \mathrm{bbl}$ & & & & & $\begin{array}{l}\text { same as } \\
\text { Alaska/North } \\
\text { Slope/Alpine }\end{array}$ \\
\hline $\begin{array}{l}\text { North Sea/Norway/ } \\
\text { Ekofisk/2/4X }\end{array}$ & $\begin{array}{l}\text { oily cuttings from up to } 49 \\
\text { wells }\end{array}$ & $\begin{array}{l}700,000 \mathrm{bbl} \\
\text { slurry }\end{array}$ & $\begin{array}{l}\text { target density } \\
9.5-12.5 \mathrm{lb} / \mathrm{gal}\end{array}$ & $\begin{array}{l}\text { centrifugal pump } \\
\text { with hardened } \\
\text { impeller; } \\
\text { macerator for } \\
\text { grinding larger } \\
\text { solids }\end{array}$ & $\begin{array}{l}\text { well has plugged on several } \\
\text { occasions due to poor } \\
\text { transport of solids in the } \\
\text { slurry; surging of well } \\
\text { reestablished injectivity }\end{array}$ & $\begin{array}{l}\text { cost of using oil- } \\
\text { based muds and } \\
\text { reinjecting } \\
\text { cuttings - } \$ 39 \\
\text { million; cost of } \\
\text { using synthetic- } \\
\text { based muds and } \\
\text { discharging } \\
\text { cuttings - } \$ 37.7 \\
\text { million }\end{array}$ & $\begin{array}{l}\text { seawater is injected } \\
\text { before and after a } \\
\text { batch of slurry; two } \\
\text { other wells on the } \\
\text { platform are } \\
\text { completed for } \\
\text { annular injection if } \\
\text { needed }\end{array}$ \\
\hline $\begin{array}{l}\text { North Sea/Norway/ Eldfisk } \\
\text { 2/7A-08 }\end{array}$ & oily cuttings & & & $\begin{array}{l}\text { centrifugal pump } \\
\text { with hardened } \\
\text { impeller; } \\
\text { macerator for } \\
\text { grinding larger } \\
\text { solids } \\
\end{array}$ & & $\begin{array}{l}\text { injection is cost- } \\
\text { effective if well } \\
\text { receives cuttings } \\
\text { from } 3 \text { or more } \\
\text { wells }\end{array}$ & $\begin{array}{l}\text { injection well is a } \\
\text { converted production } \\
\text { well }\end{array}$ \\
\hline
\end{tabular}




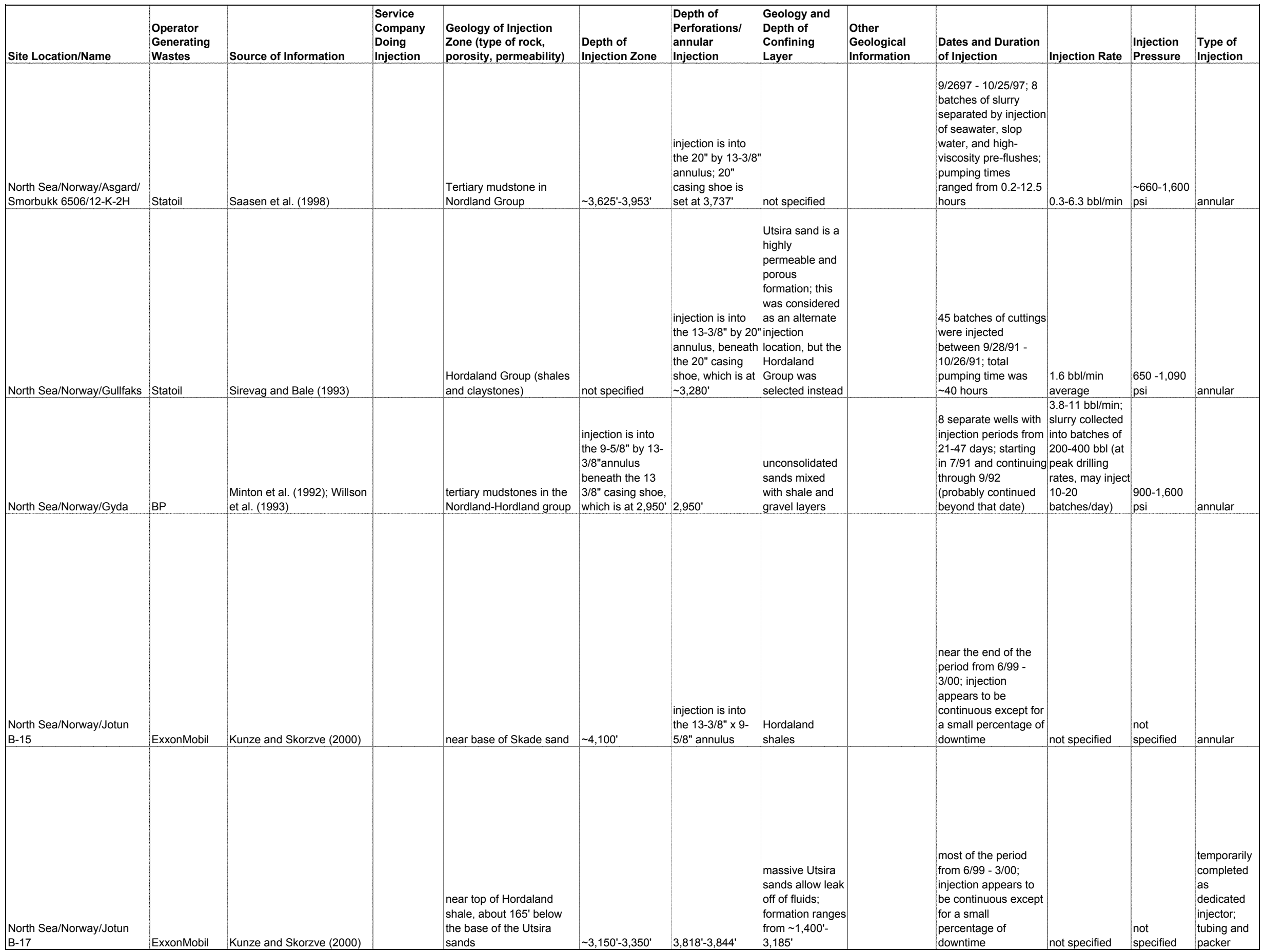




\begin{tabular}{|c|c|c|c|c|c|c|c|}
\hline Site Location/Name & Type of Waste Injected & $\begin{array}{l}\text { Volume of } \\
\text { Material } \\
\text { Injected }\end{array}$ & $\begin{array}{l}\text { Slurry } \\
\text { Properties } \\
\text { (fluid, } \\
\text { density) } \\
\end{array}$ & $\begin{array}{l}\text { Pre-Injection } \\
\text { Processing/ } \\
\text { Treatment }\end{array}$ & Problems Experienced & Costs & Other Comments \\
\hline $\begin{array}{l}\text { North Sea/Norway/Asgard/ } \\
\text { Smorbukk 6506/12-K-2H }\end{array}$ & oily cuttings, slop water & $\begin{array}{l}\sim 1,100 \mathrm{bbl} \\
\text { slurry; } 15,750 \\
\text { bbl total injectate }\end{array}$ & $\begin{array}{l}\text { density } 1.03- \\
1.4 \text { SG }\end{array}$ & crushing mill & & & $\begin{array}{l}\text { this was an } \\
\text { experimental trial to } \\
\text { test the feasibility of } \\
\text { injecting cuttings into } \\
\text { the same subsea } \\
\text { well being drilled; it } \\
\text { involved some } \\
\text { innovative } \\
\text { engineering solutions }\end{array}$ \\
\hline North Sea/Norway/Gullfaks & $\begin{array}{l}\text { oil-based cuttings, used } \\
\text { muds, and hard drilled } \\
\text { cement }\end{array}$ & $\begin{array}{l}472 \mathrm{bbl} \text { solids } \\
\text { and } 2,887 \mathrm{bbl} \\
\text { slurry }\end{array}$ & $\begin{array}{l}\text { seawater used } \\
\text { as fluid; spec. } \\
\text { grav - } 1.10- \\
1.57 \text {; solids - } 5 \text { - } \\
26 \%\end{array}$ & crushing mill & $\begin{array}{l}\text { pump bearing failed } \\
\text { (modified design and } \\
\text { lubricant); reinjection could } \\
\text { not always keep up with } \\
\text { drilling rate (provided } \\
\text { storage containers for } \\
\text { excess cuttings); }\end{array}$ & $\begin{array}{l}\text { cost savings from } \\
\text { one well were } \\
\$ 233,000 ; \\
\text { investment } \\
\text { expense was } \\
\$ 900,000 ; \text { need } \\
\text { to use system } \\
\text { several times to } \\
\text { get payback }\end{array}$ & $\begin{array}{l}\text { paper notes that } \\
\text { other Statoil projects } \\
\text { have had better cost } \\
\text { savings when using } \\
\text { reinjection }\end{array}$ \\
\hline North Sea/Norway/Gyda & $\begin{array}{l}\text { oil-based cuttings and } \\
\text { attached muds, oily water } \\
\text { from drains, centrifuge } \\
\text { discharges }\end{array}$ & $\begin{array}{l}8 \text { jobs ranging } \\
\text { from } 13,111- \\
27,000 \mathrm{bbl} \text {; total } \\
\text { through } 9 / 92 \\
\sim 140,000 \mathrm{bbl} \\
\end{array}$ & $\begin{array}{l}15 \% \text { solids and } \\
12 \% \text { oil } \\
\text { average; } \\
\text { density - } 1.17- \\
1.43 \text { SG; } \\
\text { viscosity } 68-92 \\
\text { CP }\end{array}$ & $\begin{array}{l}\text { grind solids with } \\
\text { centrifugal pump }\end{array}$ & & & $\begin{array}{l}\text { cuttings from a well } \\
\text { being drilled are } \\
\text { injected into the } \\
\text { annulus of the most } \\
\text { recently completed } \\
\text { well }\end{array}$ \\
\hline $\begin{array}{l}\text { North Sea/Norway/Jotun } \\
\text { B-15 }\end{array}$ & $\begin{array}{l}\text { oily cuttings, oil-based } \\
\text { muds, oily water, waste } \\
\text { oils, excess cement } \\
\text { mixwater, completion and } \\
\text { workover fluids }\end{array}$ & $\begin{array}{l}4,000 \text { bbl oily } \\
\text { cuttings; } 23,760 \\
\text { bbl oily water; } \\
7780 \text { bbl oil- } \\
\text { based mud }\end{array}$ & $\begin{array}{l}\text { slop water } \\
\text { used to mix } \\
\text { slurry }\end{array}$ & not specified & & $\begin{array}{l}\text { costs for } \\
\text { handling wastes } \\
\text { from } 14 \text { wells at } \\
\text { Jotun: dedicated } \\
\text { injection well } \\
\text { ( } \$ 3.5 \text { million); } \\
\text { annular injection } \\
\text { ( } \$ 3.0 \text { million); } \\
\text { land disposal } \\
\text { ( } 7.7 \text { million); } \\
\text { use of synthetic } \\
\text { muds and } \\
\text { discharge to } \\
\text { ocean }(\$ 5.9 \\
\text { million) }\end{array}$ & $\begin{array}{l}\text { several wells were } \\
\text { completed with } \\
\text { annular injection } \\
\text { zones in case the } \\
\text { primary injector } \\
\text { became clogged or } \\
\text { needed to be taken } \\
\text { out of service }\end{array}$ \\
\hline $\begin{array}{l}\text { North Sea/Norway/Jotun } \\
\text { B-17 }\end{array}$ & $\begin{array}{l}\text { oily cuttings, oil-based } \\
\text { muds, oily water, waste } \\
\text { oils, excess cement } \\
\text { mixwater, completion and } \\
\text { workover fluids }\end{array}$ & $\begin{array}{l}21,200 \text { bbl } \\
\text { cuttings; } 94,650 \\
\text { bbl oily water; } \\
1460 \text { bbl oil- } \\
\text { based mud; } 13 \\
\text { bbl waste oil }\end{array}$ & $\begin{array}{l}\text { slop water } \\
\text { used to mix } \\
\text { slurry }\end{array}$ & not specified & $\begin{array}{l}\text { when injection point was too } \\
\text { close to path of new wells } \\
\text { being drilled, this well was } \\
\text { temporarily shut in and } \\
\text { injection was switched to } \\
\text { well B-15 }\end{array}$ & see Jotun B-15 & $\begin{array}{l}\text { Injection well was } \\
\text { installed as part of a } \\
\text { new planned drilling } \\
\text { program; the injector } \\
\text { was drilled first and } \\
\text { therefore could } \\
\text { handle all oil-based } \\
\text { muds for all wells; } \\
\text { the injector could be } \\
\text { recompleted as a } \\
\text { producing well at the } \\
\text { end of the drilling } \\
\text { program } \\
\end{array}$ \\
\hline
\end{tabular}




\begin{tabular}{|c|c|c|c|c|c|c|c|c|c|c|c|c|}
\hline Site Location/Name & $\begin{array}{l}\text { Operator } \\
\text { Generating } \\
\text { Wastes } \\
\end{array}$ & Source of Information & $\begin{array}{l}\text { Service } \\
\text { Company } \\
\text { Doing } \\
\text { Injection } \\
\end{array}$ & $\begin{array}{l}\text { Geology of Injection } \\
\text { Zone (type of rock, } \\
\text { porosity, permeability) }\end{array}$ & $\begin{array}{l}\text { Depth of } \\
\text { Injection Zone }\end{array}$ & $\begin{array}{l}\text { Depth of } \\
\text { Perforations/ } \\
\text { annular } \\
\text { Injection } \\
\end{array}$ & $\begin{array}{l}\text { Geology and } \\
\text { Depth of } \\
\text { Confining } \\
\text { Layer } \\
\end{array}$ & $\begin{array}{l}\text { Other } \\
\text { Geological } \\
\text { Information }\end{array}$ & $\begin{array}{l}\text { Dates and Duration } \\
\text { of Injection }\end{array}$ & Injection Rate & $\begin{array}{l}\text { Injection } \\
\text { Pressure }\end{array}$ & $\begin{array}{l}\text { Type of } \\
\text { Injection }\end{array}$ \\
\hline North Sea/Norway/Ula & BP Norge & Minton (1996) & & & $\begin{array}{l}\text { no geological } \\
\text { data in paper; } \\
\text { injection is into } \\
\text { the } 9-5 / 8 \text { " by } 13 \text { - } \\
3 / 8 \text { "annulus } \\
\text { beneath the } 13 \\
3 / 8 \text { " casing shoe, } \\
\text { which is at } 3,570^{\prime}\end{array}$ & & & & $\begin{array}{l}\text { injection began about } \\
\text { the end of } 5 / 95 \text { and } \\
\text { included cuttings } \\
\text { from } 3 \text { wells and } \\
\text { sidetracks }\end{array}$ & $\begin{array}{l}\text { up to } 2,400 \\
\text { bbl/day; } \\
\text { generally < } \\
1,000 \text { bbl/day }\end{array}$ & $\begin{array}{l}<2,500 \text { psi } \\
\text { design max. } \\
\text { pressure }\end{array}$ & annular \\
\hline North Sea/Norway/Valhall & $\begin{array}{l}\text { Amoco and } \\
\text { later BP }\end{array}$ & $\begin{array}{l}\text { Moschovidis et al. (1993); } \\
\text { Hagan et al. (2002) }\end{array}$ & & $\begin{array}{l}\text { Eocene/Paleocene shale } \\
\text { formation; permeability: } 1 \text { - } \\
5 \mathrm{md}\end{array}$ & $\begin{array}{l}\text { not specified, but } \\
\text { believed to be } \\
>6,500^{\prime}\end{array}$ & not specified & not specified & $\begin{array}{l}\text { injection is into } \\
\text { shaly layer just } \\
\text { above the Tor } \\
\text { producing } \\
\text { formation }\end{array}$ & $\begin{array}{l}\text { well-2/8A-14A: more } \\
\text { than } 100 \text { batch } \\
\text { injections from } 1 / 90 \text { - } \\
\text { 1/91; well 2/8A-20A: } \\
\text { started in 1992, slurry } \\
\text { accumulated for } 3 \\
\text { days or } 1,000 \text { bbl } \\
\text { volume, whichever } \\
\text { came first, then } \\
\text { injected }\end{array}$ & not specified & $\begin{array}{l}\sim 3,000- \\
4,500 \mathrm{psi}\end{array}$ & $\begin{array}{l}\text { } \\
\text { tubing and } \\
\text { packer }\end{array}$ \\
\hline North Sea/Tern A & Shell & MI/SWACO (2002) & MI/SWACO & & & & & & $1 / 93-12 / 01$ & & & annular \\
\hline North Sea/UK/Brent BD-11 & Shell & $\begin{array}{l}\text { Brakel et al (1997); Van Gils } \\
\text { et al. (1995) }\end{array}$ & & $\begin{array}{l}\text { Hutton sands (interbedded } \\
\text { sand and clay) }\end{array}$ & $-2,900^{\prime}-4,000^{\prime}$ & $\begin{array}{l}\text { injection is into } \\
\text { the } 20^{\prime \prime} \text { by } 13-3 / 8 \\
\text { annulus; injection } \\
\text { point is at } 2,953^{\prime}\end{array}$ & $\begin{array}{l}\text { Hutton sands } \\
\text { (sand and clay } \\
\text { "layers); near } \\
\text { seabed to } \\
\sim 4,500^{\prime}\end{array}$ & $\begin{array}{l}\text { underlain by } \\
\text { Hutton clay, } \\
\text { Rogaland, } \\
\text { Montrose, and } \\
\text { Shetland groups }\end{array}$ & $\begin{array}{l}\text { unspecified, but prior } \\
\text { to } 1997\end{array}$ & $\begin{array}{l}\text { not specified, } \\
\text { but planned rate } \\
\text { of } 4 \mathrm{bbl} / \mathrm{min}\end{array}$ & $450-800 \mathrm{psi}$ & i annular \\
\hline $\begin{array}{l}\text { North Sea/UK/Andrew/ } \\
\text { 16-28-A06 }\end{array}$ & BP & Apollo Services (2002) & $\begin{array}{l}\text { Apollo } \\
\text { Services }\end{array}$ & & & & & & & & & annular \\
\hline $\begin{array}{l}\text { North Sea/UK/Andrew/ } \\
16-28-A 07\end{array}$ & BP & Apollo Services (2002) & $\begin{array}{l}\text { Apollo } \\
\text { Services }\end{array}$ & & & & & & $9 / 97-9 / 98$ & $2 \mathrm{bbl} / \mathrm{min}$ & $\begin{array}{l}1,200-1,600 \\
\text { psi }\end{array}$ & annular \\
\hline North Sea/UK/Block 22/25 & $\begin{array}{l}12 \text { operators } \\
\text { as part of } \\
\text { research } \\
\text { project }\end{array}$ & Ferguson et al. (1993) & $\begin{array}{l}\text { Thule } \\
\text { Rigtech }\end{array}$ & Pliocene mudstone & $\begin{array}{l}\text { injection is into } \\
\text { the } 13-3 / 8^{\prime \prime} \times 20 " \\
\text { annulus }\end{array}$ & & & & $\begin{array}{l}\text { trial began on or } \\
\text { about } 3 / 24 / 93 \text {; initially } \\
\text { injected seawater to } \\
\text { fracture formation, } \\
\text { then two 2-hour } \\
\text { injection periods with } \\
\text { a rest in between, } \\
\text { then final seawater } \\
\text { injection }\end{array}$ & $\begin{array}{l} \\
\text { slurry injected at } \\
4 \mathrm{bbl} / \mathrm{min} \\
\end{array}$ & $\begin{array}{l}\text { seawater - } \\
1,900 \mathrm{psi} \\
\text { and } 700 \mathrm{psi} ; \\
\text { slurries } 540 \\
\text { it psi and } 650 \\
\text { psi }\end{array}$ & annular \\
\hline
\end{tabular}




\begin{tabular}{|c|c|c|c|c|c|c|c|}
\hline Site Location/Name & Type of Waste Injected & $\begin{array}{l}\text { Volume of } \\
\text { Material } \\
\text { Injected } \\
\end{array}$ & $\begin{array}{l}\text { Slurry } \\
\text { Properties } \\
\text { (fluid, } \\
\text { density) } \\
\end{array}$ & $\begin{array}{l}\text { Pre-Injection } \\
\text { Processing/ } \\
\text { Treatment }\end{array}$ & Problems Experienced & Costs & Other Comments \\
\hline North Sea/Norway/Ula & $\begin{array}{l}\text { oil-based cuttings and } \\
\text { attached muds, oily water } \\
\text { from drains, centrifuge } \\
\text { discharges }\end{array}$ & $55,465 \mathrm{bbl}$ & $\begin{array}{l}\text { density (s.g.) - } \\
1.17-1.38 ; \\
\text { viscosity (secs) } \\
-42-110 ; \\
\text { solids (\%) - 12- } \\
26 \text {; oil (\%) - 4- } \\
14\end{array}$ & & $\begin{array}{l}\text { system was called upon to } \\
\text { handle larger than design } \\
\text { flow; some larger particles } \\
\text { that had not had sufficient } \\
\text { residence time to break } \\
\text { down caused pumping } \\
\text { problems (solved by adding } \\
\text { a screen to exclude large } \\
\text { particles); hydratable clays } \\
\text { swelled and blocked pipe } \\
\text { line (solved by adding } \\
\text { dispersant) }\end{array}$ & $\begin{array}{l}\text { capital and } \\
\text { installation - } \\
\$ 270,000 ; \\
\text { estimated cost } \\
\text { savings vs. } \\
\text { synthetic muds } \\
\text { ( } \$ 3 \text { million) }\end{array}$ & $\begin{array}{l}\text { space and layout } \\
\text { constraints caused } \\
\text { BP to change design } \\
\text { of system several } \\
\text { times }\end{array}$ \\
\hline North Sea/Norway/Valhall & $\begin{array}{l}\text { well-2/8A-14A: cuttings } \\
\text { wash water with } 4 \% \\
\text { solids; well } 2 / 8 \mathrm{~A}-20 \mathrm{~A} \text { : oil- } \\
\text { based cuttings }\end{array}$ & $\begin{array}{l}\text { well-2/8A-14A: } \\
120,000 \mathrm{bbl} \\
\text { slurry containing } \\
>4.4 \text { million Ib of } \\
\text { solids; well 2/8A- } \\
20 \mathrm{~A}: 42,000 \mathrm{bbl} \\
\text { slurry containing } \\
>17 \text { million Ib of } \\
\text { solids } \\
\text { (Moschovidis et } \\
\text { al. } 1993 \text { ); more } \\
\text { recent injection } \\
\text { is } 2,000-2,500 \\
\text { bbl twice per day } \\
\text { of seawater flush } \\
\text { and waste slurry } \\
\text { (Hagan et al. } \\
2002 \text { ) }\end{array}$ & $\begin{array}{l}\text { sea water use } \\
\text { as fluid; } \\
\text { density - } \\
\text { 10lb/gal }\end{array}$ & $\begin{array}{l}\text { centrifugal pump } \\
\text { used to break } \\
\text { solids into smaller } \\
\text { particles }\end{array}$ & $\begin{array}{l}\text { erosional wear and } \\
\text { injectivity served to } \\
\text { downgrade operational } \\
\text { integrity }\end{array}$ & $\begin{array}{l}\text { estimated } \\
\text { savings of } \\
\$ 550,000 / \text { well vs } \\
\text { onshore disposa }\end{array}$ & $\begin{array}{l}\text { Moschovidis et al. } \\
\text { (1993) describe the } \\
\text { early trials; cuttings } \\
\text { reinjection continued } \\
\text { after 1992, but at } \\
\text { some point the } \\
\text { injection well began } \\
\text { use as a produced } \\
\text { water injector, and } \\
\text { waste was injected } \\
\text { intermittently (Hagan } \\
\text { et al. 2002) }\end{array}$ \\
\hline North Sea/Tern A & oil-based cuttings & $153,883 \mathrm{bbl}$ & & & & & $\begin{array}{l}\text { same as } \\
\text { Alaska/North } \\
\text { Slope/Alpine }\end{array}$ \\
\hline North Sea/UK/Brent BD-11 & oil-based cuttings & 4,256 bbl slurry & $\begin{array}{l}\text { density - 1.38- } \\
1.57 \text { SG; } \\
\text { viscosity } 62-90 \\
\text { sec.; seawater } \\
\text { is the fluid }\end{array}$ & $\begin{array}{l}\text { grinding mills and } \\
\text { mixing tanks }\end{array}$ & $\begin{array}{l}\text { sometimes solids settle out } \\
\text { in the annulus or plug the } \\
\text { annulus, stopping injection; } \\
\text { transfer of slurry to injection } \\
\text { well could not always keep } \\
\text { up with drilling; problems } \\
\text { solved by shifting to } \\
\text { shallower formations }\end{array}$ & $\begin{array}{l}\text { average cost of } \\
£ 17 / \mathrm{bbl} \text { or } \\
£ 390 / \text { metric ton } \\
\text { of cuttings }\end{array}$ & \\
\hline $\begin{array}{l}\text { North Sea/UK/Andrew/ } \\
\text { 16-28-A06 }\end{array}$ & cuttings & 12,762 bbl slurry & & & & & $\begin{array}{l}\text { limited data provided } \\
\text { for this job }\end{array}$ \\
\hline \begin{tabular}{|l} 
North Sea/UK/Andrew/ \\
16-28-A07
\end{tabular} & cuttings & 13,756 bbl slurry & & & & & $\begin{array}{l}\text { limited data provided } \\
\text { for this job }\end{array}$ \\
\hline North Sea/UK/Block 22/25 & $\begin{array}{l}\text { artificial slurry because } \\
\text { timing of trial did not allow } \\
\text { actual cuttings injection }\end{array}$ & $\begin{array}{l}3,596 \mathrm{bbl} \text { total } \\
\text { fluid; } 1,284 \mathrm{bbl} \\
\text { slurry }\end{array}$ & $\begin{array}{l}\text { spec.grav - } \\
1.16 ; \text { viscosity } \\
49-51 ; \% \\
\text { solids - } 11-16 \\
\end{array}$ & & & & $\begin{array}{l}\text { this was an } \\
\text { experimental trial to } \\
\text { test the feasibility of } \\
\text { injecting from a } \\
\text { floating drilling rig; } \\
\text { the test was } \\
\text { successful and } \\
\text { involved some } \\
\text { innovative } \\
\text { engineering solutions }\end{array}$ \\
\hline
\end{tabular}




\begin{tabular}{|c|c|c|c|c|c|c|c|c|c|c|c|c|}
\hline Site Location/Name & $\begin{array}{l}\text { Operator } \\
\text { Generating } \\
\text { Wastes } \\
\end{array}$ & Source of Information & $\begin{array}{l}\text { Service } \\
\text { Company } \\
\text { Doing } \\
\text { Injection } \\
\end{array}$ & $\begin{array}{l}\text { Geology of Injection } \\
\text { Zone (type of rock, } \\
\text { porosity, permeability) }\end{array}$ & $\begin{array}{l}\text { Depth of } \\
\text { Injection Zone }\end{array}$ & \begin{tabular}{|l|} 
Depth of \\
Perforations/ \\
annular \\
Injection \\
\end{tabular} & $\begin{array}{l}\text { Geology and } \\
\text { Depth of } \\
\text { Confining } \\
\text { Layer } \\
\end{array}$ & $\begin{array}{l}\text { Other } \\
\text { Geological } \\
\text { Information }\end{array}$ & $\begin{array}{l}\text { Dates and Duration } \\
\text { of Injection }\end{array}$ & Injection Rate & $\begin{array}{l}\text { Injection } \\
\text { Pressure }\end{array}$ & $\begin{array}{l}\text { Type of } \\
\text { Injection }\end{array}$ \\
\hline $\begin{array}{l}\text { North Sea/UK/Block } \\
\text { 44/22/Murdoch }\end{array}$ & Conoco & Schuh et al. (1993) & $\begin{array}{l}\text { Thule } \\
\text { Rigtech }\end{array}$ & $\begin{array}{l}\text { Bunter sand/shale } \\
\text { sequence; sand layers } \\
\text { have } 25 \% \text { porosity, } 1 \text { darcy } \\
\text { permeability }\end{array}$ & $6,200^{\prime}-7,000^{\prime}$ & $\begin{array}{l}6,375^{\prime}-6,415^{\prime} ; \\
\text { injection is into } \\
\text { the } 9-58^{\prime \prime} \text { by } 13- \\
3 / 8^{\prime \prime} \text { annulus }\end{array}$ & $\begin{array}{l}200 \text { ' thick layer } \\
\text { of Rot halite }\end{array}$ & $\begin{array}{l}\text { 1,500' of Bunter } \\
\text { shale lies below } \\
\text { the injection layer }\end{array}$ & $\begin{array}{l}12 / 91 \text { - } 3 / 93 \text {; five } \\
\text { wells were drilled at } \\
\text { the Murdoch project; } \\
\text { the first was } \\
\text { converted to an } \\
\text { rinjection well }\end{array}$ & $\begin{array}{l}\text { injection made } \\
\text { in batches from } \\
150 \text { bbl holding } \\
\text { tank; rates } \\
\text { ranged from } 3 \\
\text { tanks/day to } \\
\text { less than } 1 \\
\text { tank/day }\end{array}$ & $\begin{array}{l}>2,000 \mathrm{psi} \\
\text { average; } \\
3,200 \mathrm{psi} \\
\text { maximum }\end{array}$ & annular \\
\hline North Sea/UK/Brent BA-17 & Shell & $\begin{array}{l}\text { Brakel et al (1997); Van Gils } \\
\text { et al. (1995) }\end{array}$ & & $\begin{array}{l}\text { Hutton sands (interbedded } \\
\text { sand and clay) }\end{array}$ & not specified & $\begin{array}{l}\text { injection is into } \\
\text { the } 20^{\prime \prime} \text { by } 13-3 / 8^{\prime \prime} \\
\text { annulus; injection } \\
\text { point is at } 4,124\end{array}$ & $\begin{array}{l}\text { Hutton sands } \\
\text { (sand and clay } \\
\text { "layers); near } \\
\text { seabed to } \\
\sim 4,500^{\prime} \\
\end{array}$ & & $\begin{array}{l}\text { unspecified, but prior } \\
\text { to } 1997\end{array}$ & $\begin{array}{l}\text { not specified, } \\
\text { but planned rate } \\
\text { of } 4 \mathrm{bbl} / \mathrm{min}\end{array}$ & $\begin{array}{l}\text { e } 1,100-1,450 \\
\text { psi }\end{array}$ & annular \\
\hline North Sea/UK/Brent BA-23 & Shell & $\begin{array}{l}\text { Brakel et al (1997); Van Gils } \\
\text { et al. (1995) }\end{array}$ & & $\begin{array}{l}\text { Shetland Group (clays, } \\
\text { marls, local sands and } \\
\text { limestones) }\end{array}$ & $\sim 5,300^{\prime}-7,000^{\prime}$ & $\begin{array}{l}\text { injection is into } \\
\text { the } 13-3 / 8^{\prime \prime} \times 9- \\
5 / 8^{\prime \prime} \text { annulus; } \\
\text { injection point is } \\
\text { at } 6,636^{\prime}\end{array}$ & $\begin{array}{l}\text { Montrose group } \\
\text { (clays) at 5,800'- } \\
6,200^{\prime} \text { ) }\end{array}$ & & $\begin{array}{l}\text { unspecified, but prior } \\
\text { to } 1997\end{array}$ & $\begin{array}{l}\text { not specified, } \\
\text { but planned rate } \\
\text { of } 4 \mathrm{bbl} / \mathrm{min}\end{array}$ & $\begin{array}{l}1,500-1,675 \\
\text { psi }\end{array}$ & annular \\
\hline North Sea/UK/Brent BA-25 & Shell & $\begin{array}{l}\text { Brakel et al (1997); Van Gils } \\
\text { et al. (1995) }\end{array}$ & & $\begin{array}{l}\text { Hutton sands (interbedded } \\
\text { sand and clay) }\end{array}$ & not specified & $\begin{array}{l}\text { injection is into } \\
\text { the } 20^{\prime \prime} \text { by } 13-3 / 8^{\prime \prime} \\
\text { annulus; injection } \\
\text { point is at } 4,501^{\prime}\end{array}$ & $\begin{array}{l}\text { Hutton sands } \\
\text { (sand and clay } \\
\text { "layers); near } \\
\text { seabed to } \\
\sim 4,500^{\prime}\end{array}$ & & $\begin{array}{l}\text { unspecified, but prior } \\
\text { to } 1997\end{array}$ & $\begin{array}{l}\text { not specified, } \\
\text { but planned rate } \\
\text { of } 4 \mathrm{bbl} / \mathrm{min}\end{array}$ & $\begin{array}{l}1,450-1,800 \\
\text { psi }\end{array}$ & annular \\
\hline $\begin{array}{l}\text { North Sea/UK/Brent } \\
\text { BB-01-S1 }\end{array}$ & Shell & Apollo Services (2002) & $\begin{array}{l}\text { Apollo } \\
\text { Services }\end{array}$ & & & & & & & & & annular \\
\hline North Sea/UK/Brent BB-11 & Shell & $\begin{array}{l}\text { Brakel et al (1997); van Gils } \\
\text { et al. (1995) }\end{array}$ & & $\begin{array}{l}\text { Hutton sands (interbedded } \\
\text { sand and clay) }\end{array}$ & not specified & $\begin{array}{l}\text { injection is into } \\
\text { the } 20^{\prime \prime} \text { by } 13-3 / 8^{\prime \prime} \\
\text { annulus; injection } \\
\text { point is at } 4,531^{\prime}\end{array}$ & $\begin{array}{l}\text { Hutton sands } \\
\text { (sand and clay } \\
\text { "layers); near } \\
\text { seabed to } \\
\sim 4,500^{\prime}\end{array}$ & & $\begin{array}{l}\text { unspecified, but prior } \\
\text { to } 1997\end{array}$ & $\begin{array}{l}\text { not specified, } \\
\text { but planned rate } \\
\text { of } 4 \mathrm{bbl} / \mathrm{min}\end{array}$ & $\begin{array}{l}1,000-1,150 \\
\text { psi }\end{array}$ & annular \\
\hline $\begin{array}{l}\text { North Sea/UK/Brent } \\
\text { BB-14-S1 }\end{array}$ & Shell & Apollo Services (2002) & $\begin{array}{l}\text { Apollo } \\
\text { Services }\end{array}$ & & & & & & & & & annular \\
\hline North Sea/UK/Brent BB-15 & Shell & $\begin{array}{l}\text { Brakel et al (1997); van Gils } \\
\text { et al. (1995) }\end{array}$ & & $\begin{array}{l}\text { multiple layers of shales } \\
\text { and claystones (Hutton } \\
\text { Clay, Montrose Group, } \\
\text { Shetland Group); }\end{array}$ & not specified & $\begin{array}{l}\text { injection is into } \\
\text { the } 20 \text { " by } 13-3 / 8^{\prime \prime} \\
\text { annulus; injection } \\
\text { point is at } 3,329^{\prime}\end{array}$ & $\begin{array}{l}\text { Hutton sands } \\
\text { (sand and clay } \\
\text { "layers); near } \\
\text { seabed to } \\
\sim 4,500^{\prime}\end{array}$ & & $\begin{array}{l}\text { unspecified, but prior } \\
\text { to } 1997\end{array}$ & $\begin{array}{l}\text { not specified, } \\
\text { but planned rate } \\
\text { of } 4 \mathrm{bbl} / \mathrm{min}\end{array}$ & $750-850 \mathrm{psi}$ & annular \\
\hline
\end{tabular}




\begin{tabular}{|c|c|c|c|c|c|c|c|}
\hline Site Location/Name & Type of Waste Injected & $\begin{array}{l}\text { Volume of } \\
\text { Material } \\
\text { Injected } \\
\end{array}$ & $\begin{array}{l}\text { Slurry } \\
\text { Properties } \\
\text { (fluid, } \\
\text { density) } \\
\end{array}$ & $\begin{array}{l}\text { Pre-Injection } \\
\text { Processing/ } \\
\text { Treatment }\end{array}$ & Problems Experienced & Costs & Other Comments \\
\hline $\begin{array}{l}\text { North Sea/UK/Block } \\
44 / 22 / \text { Murdoch }\end{array}$ & $\begin{array}{l}\text { oily cuttings, centrifuge } \\
\text { underflow }\end{array}$ & $\begin{array}{l}20,000 \text { bbl slurry } \\
\text { and } 18,000 \mathrm{bbl} \\
\text { seawater }\end{array}$ & $\begin{array}{l}\text { seawater used } \\
\text { as fluid; target } \\
\text { density } 1.5 \mathrm{sg} ; \\
\text { target viscosity } \\
-50-100 \\
\text { sec/quart; } \\
\text { target solids } \\
>25 \%\end{array}$ & $\begin{array}{l}\text { grinding mills and } \\
\text { mixing tanks }\end{array}$ & $\begin{array}{l}\text { some rig downtime was due } \\
\text { to human error (loss of air } \\
\text { supply, power supply } \\
\text { fluctuations, loss of power, } \\
\text { leaks); inappropriate } \\
\text { materials in feed clogged } \\
\text { conveyors; problems } \\
\text { occurred more frequently } \\
\text { when drilling largest } \\
\text { diameter hole and when } \\
\text { centrifuge underflow was } \\
\text { added to the injectate }\end{array}$ & $\begin{array}{l}\text { cuttings injection } \\
\text { was } 27 \% \text { more } \\
\text { expensive than } \\
\text { cuttings cleaning } \\
\text { and discharge } \\
\text { ( } £ 859,000 \text { vs. } \\
£ 630,000 \text { ); } \\
\text { authors believe } \\
\text { that costs could } \\
\text { be reduced } \\
\text { significantly }\end{array}$ & $\begin{array}{l}\text { the injection process } \\
\text { was designed as } \\
\text { part of the drilling } \\
\text { program; sufficiently } \\
\text { strong casings were } \\
\text { used in the injector } \\
\text { well }\end{array}$ \\
\hline North Sea/UK/Brent BA-17 & oil-based cuttings & 1,956 bbl slurry & $\begin{array}{l}\text { density - } 1.30 \\
\text { SG; viscosity } \\
80 \text { sec.; } \\
\text { seawater is the } \\
\text { fluid }\end{array}$ & $\begin{array}{l}\text { grinding mills and } \\
\text { mixing tanks }\end{array}$ & $\begin{array}{l}\text { sometimes solids settle out } \\
\text { in the annulus or plug the } \\
\text { annulus, stopping injection; } \\
\text { transfer of slurry to injection } \\
\text { well could not always keep } \\
\text { up with drilling; problems } \\
\text { solved by shifting to } \\
\text { shallower formations }\end{array}$ & $\begin{array}{l}\text { average cost of } \\
£ 17 / \mathrm{bbl} \text { or } \\
£ 390 / \text { metric ton } \\
\text { of cuttings }\end{array}$ & \\
\hline North Sea/UK/Brent BA-23 & oil-based cuttings & 4,678 bbl slurry & $\begin{array}{l}\text { density - 1.25- } \\
1.50 \text { SG; } \\
\text { viscosity } 85-90 \\
\text { sec.; seawater } \\
\text { is the fluid }\end{array}$ & $\begin{array}{l}\text { grinding mills and } \\
\text { mixing tanks }\end{array}$ & $\begin{array}{l}\text { sometimes solids settle out } \\
\text { in the annulus or plug the } \\
\text { annulus, stopping injection; } \\
\text { transfer of slurry to injection } \\
\text { well could not always keep } \\
\text { up with drilling; problems } \\
\text { solved by shifting to } \\
\text { shallower formations }\end{array}$ & $\begin{array}{l}\text { average cost of } \\
£ 17 / \mathrm{bbl} \text { or } \\
£ 390 / \mathrm{metric} \text { ton } \\
\text { of cuttings }\end{array}$ & \\
\hline North Sea/UK/Brent BA-25 & oil-based cuttings & 1,361 bbl slurry & $\begin{array}{l}\text { density - 1.27- } \\
1.60 \mathrm{SG} ; \\
\text { viscosity } 80 \\
\text { sec.; seawater } \\
\text { is the fluid }\end{array}$ & $\begin{array}{l}\text { grinding mills and } \\
\text { mixing tanks }\end{array}$ & $\begin{array}{l}\text { sometimes solids settle out } \\
\text { in the annulus or plug the } \\
\text { annulus, stopping injection; } \\
\text { transfer of slurry to injection } \\
\text { well could not always keep } \\
\text { up with drilling; problems } \\
\text { solved by shifting to } \\
\text { shallower formations }\end{array}$ & $\begin{array}{l}\text { average cost of } \\
£ 17 / \mathrm{bbl} \text { or } \\
£ 390 / \mathrm{metric} \text { ton } \\
\text { of cuttings }\end{array}$ & \\
\hline $\begin{array}{l}\text { North Sea/UK/Brent } \\
\text { BB-01-S1 }\end{array}$ & cuttings & 18,972 bbl slurry & & & & & $\begin{array}{l}\text { limited data provided } \\
\text { for this job }\end{array}$ \\
\hline North Sea/UK/Brent BB-11 & oil-based cuttings & 41,808 bbl slurry & $\begin{array}{l}\text { density - 1.20- } \\
1.29 \mathrm{SG} ; \\
\text { viscosity } 50-55 \\
\text { sec.; seawater } \\
\text { is the fluid }\end{array}$ & $\begin{array}{l}\text { centrifugal pump } \\
\text { used to break } \\
\text { solids into smaller } \\
\text { particles }\end{array}$ & $\begin{array}{l}\text { sometimes solids settle out } \\
\text { in the annulus or plug the } \\
\text { annulus, stopping injection; } \\
\text { transfer of slurry to injection } \\
\text { well could not always keep } \\
\text { up with drilling; problems } \\
\text { solved by shifting to } \\
\text { shallower formations }\end{array}$ & $\begin{array}{l}\text { average cost of } \\
£ 17 / \mathrm{bbl} \text { or } \\
£ 390 / \text { metric ton } \\
\text { of cuttings }\end{array}$ & \\
\hline $\begin{array}{l}\text { North Sea/UK/Brent } \\
\text { BB-14-S1 }\end{array}$ & cuttings & 9,155 bbl slurry & & & & & $\begin{array}{l}\text { limited data provided } \\
\text { for this job }\end{array}$ \\
\hline North Sea/UK/Brent BB-15 & oil-based cuttings & $7,469 \mathrm{bbl}$ slurry & $\begin{array}{l}\text { density - 1.15- } \\
1.27 \mathrm{SG} ; \\
\text { viscosity } 55-58 \\
\text { sec.; seawater } \\
\text { is the fluid }\end{array}$ & $\begin{array}{l}\text { centrifugal pump } \\
\text { used to break } \\
\text { solids into smaller } \\
\text { particles }\end{array}$ & $\begin{array}{l}\text { sometimes solids settle out } \\
\text { in the annulus or plug the } \\
\text { annulus, stopping injection; } \\
\text { transfer of slurry to injection } \\
\text { well could not always keep } \\
\text { up with drilling; problems } \\
\text { solved by shifting to } \\
\text { shallower formations }\end{array}$ & $\begin{array}{l}\text { average cost of } \\
£ 17 / \mathrm{bbl} \text { or } \\
£ 390 / \mathrm{metric} \text { ton } \\
\text { of cuttings }\end{array}$ & \\
\hline
\end{tabular}




\begin{tabular}{|c|c|c|c|c|c|c|c|c|c|c|c|c|}
\hline Site Location/Name & $\begin{array}{l}\text { Operator } \\
\text { Generating } \\
\text { Wastes }\end{array}$ & Source of Information & $\begin{array}{l}\text { Service } \\
\text { Company } \\
\text { Doing } \\
\text { Injection } \\
\end{array}$ & $\begin{array}{l}\text { Geology of Injection } \\
\text { Zone (type of rock, } \\
\text { porosity, permeability) }\end{array}$ & $\begin{array}{l}\text { Depth of } \\
\text { Injection Zone }\end{array}$ & \begin{tabular}{|l|} 
Depth of \\
Perforations/ \\
annular \\
Injection \\
\end{tabular} & $\begin{array}{l}\text { Geology and } \\
\text { Depth of } \\
\text { Confining } \\
\text { Layer } \\
\end{array}$ & $\begin{array}{l}\text { Other } \\
\text { Geological } \\
\text { Information }\end{array}$ & $\begin{array}{l}\text { Dates and Duration } \\
\text { of Injection }\end{array}$ & Injection Rate & $\begin{array}{l}\text { Injection } \\
\text { Pressure }\end{array}$ & $\begin{array}{l}\text { Type of } \\
\text { Injection }\end{array}$ \\
\hline $\begin{array}{l}\text { North Sea/UK/Brent } \\
\text { BB-19-S2 }\end{array}$ & Shell & Apollo Services (2002) & $\begin{array}{l}\text { Apollo } \\
\text { Services }\end{array}$ & & & & & & & & & annular \\
\hline $\begin{array}{l}\text { North Sea/UK/Brent } \\
\text { BB-32-S3 }\end{array}$ & Shell & Apollo Services (2002) & $\begin{array}{l}\text { Apollo } \\
\text { Services }\end{array}$ & & & & & & & & & annular \\
\hline North Sea/UK/Clyde & BP & Minton and Secoy (1992) & & tertiary mudstones & $\sim 2,500^{\prime}-5,650^{\prime}$ & $\begin{array}{l}\text { injection is into } \\
\text { the } 13-3 / 8^{\prime \prime} \times 20^{\prime \prime} \\
\text { annulus; } 20^{\prime \prime} \\
\text { casing shoe is } \\
\text { set at about } \\
2,500^{\prime}\end{array}$ & $\begin{array}{l}\begin{array}{l}\text { Pleistocene } \\
\text { shale }\end{array} \\
\end{array}$ & $\begin{array}{l}\text { injection zone } \\
\text { underlain by } \\
\text { Oligocene shales }\end{array}$ & $\begin{array}{l}\text { date not specified } \\
\text { (between } 1990 \text { and } \\
\text { 1992); } 3 \text { small } \\
\text { batches of slurry } \\
\text { injected over four- } \\
\text { hour periods } \\
\text { separated by 24-96 } \\
\text { hour resting periods } \\
\end{array}$ & 2.3-3 bbl/min & $435 \mathrm{psi}$ & annular \\
\hline $\begin{array}{l}\text { North Sea/UK/Ninian } \\
\text { Central }\end{array}$ & Kerr-McGee & Wittenbach (2002) & $\begin{array}{l}\text { Apollo } \\
\text { Services/ } \\
\text { MGA } \\
\text { Consultancy } \\
\text { Services }\end{array}$ & shale formation & $4,190^{\prime}-5,500^{\prime}$ & & $\begin{array}{l}\text { sandstone layer } \\
\text { above }\end{array}$ & & & & & $\begin{array}{l}\text { tubing and } \\
\text { packer }\end{array}$ \\
\hline North Sea/UK/Ninian South & Kerr-McGee & Wittenbach (2002) & $\begin{array}{l}\text { Apollo } \\
\text { Services/ } \\
\text { MGA } \\
\text { Consultancy } \\
\text { Services } \\
\end{array}$ & shale formation & $4,850^{\prime}-6,041^{\prime}$ & & $\begin{array}{l}\text { sandstone layer } \\
\text { above }\end{array}$ & & & & & $\begin{array}{l}\text { tubing and } \\
\text { packer }\end{array}$ \\
\hline Oklahoma/Mounds site & $\begin{array}{l}\text { research } \\
\text { consortium }\end{array}$ & $\begin{array}{l}\text { Moschovidis et al. (1999, } \\
\text { 2000); GRI (1999) }\end{array}$ & & $\begin{array}{l}\text { injection made into two } \\
\text { zones - Wilcox sand and } \\
\text { Atoka shale }\end{array}$ & $\begin{array}{l}\text { Wilcox - 2,647'- } \\
\text { 2,742'; Atoka - } \\
1,751^{\prime}-2,000^{\prime}\end{array}$ & $\begin{array}{l}\text { Wilcox - 2,712'- } \\
2,748^{\prime} ; \text { Atoka - } \\
1,940^{\prime}-1,960^{\prime}\end{array}$ & Woodford shale & $\begin{array}{l}\text { extensive } \\
\text { monitoring data } \\
\text { collected during } \\
\text { trials (tiltmeters, } \\
\text { monitoring wells, } \\
\text { tracers, } \\
\text { microseismic } \\
\text { monitoring) }\end{array}$ & $\begin{array}{l}\text { Wilcox - } 17 \text { batches } \\
\text { of slurry over } 3 \text { days; } \\
\text { Atoka }-20 \text { batches of } \\
\text { slurry over } 3 \text { days; } \\
\text { batches were about } \\
50 \text { bbl; experiments } \\
\text { done during } 1998\end{array}$ & $4-5 \mathrm{bbl} / \mathrm{min}$ & $\begin{array}{l}\text { bottom hole } \\
\text { pressures: } \\
\text { Wilcox - } \\
1,100-1,800 \\
\text { psi; Atoka } \\
1,100-1,700 \\
\text { psi }\end{array}$ & $\begin{array}{l}\text { Wilcox - } \\
\text { annular; } \\
\text { Atoka - } \\
\text { tubing and } \\
\text { packer } \\
\text { through } \\
\text { perfs }\end{array}$ \\
\hline Russia/Sakhalin/Chayvo 6 & $\begin{array}{l}\text { Exxon Neftgas } \\
\text { Ltd, Russia }\end{array}$ & Apollo Services (2002) & $\begin{array}{l}\text { Apollo } \\
\text { Services } \\
\end{array}$ & & & $2,275^{\prime}$ & & & $8 / 7 / 00-9 / 3 / 00$ & $1.5-2.2 \mathrm{bbl} / \mathrm{min}$ & $350-445 \mathrm{psi}$ & annular \\
\hline Texas onshore/\#1 & Delmar & Apollo Services (2002) & $\begin{array}{l}\text { Apollo } \\
\text { Services }\end{array}$ & & & & & & & & & annular \\
\hline Texas onshore/\#1 & Hunt Oil & Apollo Services (2002) & $\begin{array}{l}\text { Apollo } \\
\text { Services }\end{array}$ & & & & & & & & & annular \\
\hline $\begin{array}{l}\text { Texas onshore/El } \\
\text { Campo/Krejci \#1 }\end{array}$ & Oxy U.S.A. & Apollo Services (2002) & $\begin{array}{l}\text { Apollo } \\
\text { Services }\end{array}$ & & & & & & & & & annular \\
\hline $\begin{array}{l}\text { Texas onshore/Fort } \\
\text { Stockton/Tomahawk \#1 }\end{array}$ & Hunt Oil & Apollo Services (2002) & $\begin{array}{l}\text { Apollo } \\
\text { Services } \\
\end{array}$ & & & & & & & & & annular \\
\hline $\begin{array}{l}\text { Texas onshore/Jasper } \\
\text { County }\end{array}$ & ARCO & Keck and Withers (1994) & & $\begin{array}{l}\text { Lower Frio sand; } \\
\text { permeability 1-3 darcies; } \\
\text { porosity } 35 \%\end{array}$ & $\sim 4,400^{\prime}-4,600^{\prime}$ & $4,426^{\prime}-4,614^{\prime}$ & $\begin{array}{l}\text { 130' layer of } \\
\text { shale above } \\
\text { Lower Frio sand }\end{array}$ & $\begin{array}{l}\text { 1,500' of } \\
\text { shale/shaley- } \\
\text { sand sequences } \\
\text { below Lower Frio } \\
\text { sands }\end{array}$ & $\begin{array}{l}4 \text { injection cycles ( } 20- \\
28 \text { hours each) over } 5 \\
\text { days in } 10 / 93\end{array}$ & $10-15 \mathrm{bbl} / \mathrm{min}$ & $\begin{array}{l}\text { bottom hole } \\
\text { pressure: } \\
\sim 3,000- \\
3,500 \text { psi } \\
\end{array}$ & $\begin{array}{l}\text { tubing and } \\
\text { packer }\end{array}$ \\
\hline $\begin{array}{l}\text { Texas onshore/Zapata/Vela } \\
\text { Lopena \#1 }\end{array}$ & Oxy U.S.A. & Apollo Services (2002) & $\begin{array}{l}\text { Apollo } \\
\text { Services }\end{array}$ & & & & & & & & & annular \\
\hline Thailand/Satoon Bravo & Unocal & Apollo Services (2002) & $\begin{array}{l}\text { Apollo } \\
\text { Services } \\
\end{array}$ & & & & & & & & & annular \\
\hline
\end{tabular}




\begin{tabular}{|c|c|c|c|c|c|c|c|}
\hline Site Location/Name & Type of Waste Injected & $\begin{array}{l}\text { Volume of } \\
\text { Material } \\
\text { Injected } \\
\end{array}$ & $\begin{array}{l}\text { Slurry } \\
\text { Properties } \\
\text { (fluid, } \\
\text { density) } \\
\end{array}$ & $\begin{array}{l}\text { Pre-Injection } \\
\text { Processing/ } \\
\text { Treatment }\end{array}$ & Problems Experienced & Costs & Other Comments \\
\hline $\begin{array}{l}\text { North Sea/UK/Brent } \\
\text { BB-19-S2 }\end{array}$ & cuttings & 4,423 bbl slurry & & & & & $\begin{array}{l}\text { limited data provided } \\
\text { for this job }\end{array}$ \\
\hline $\begin{array}{l}\text { North Sea/UK/Brent } \\
\text { BB-32-S3 }\end{array}$ & cuttings & 10,910 bbl slurry & & & & & $\begin{array}{l}\text { limited data provided } \\
\text { for this job }\end{array}$ \\
\hline North Sea/UK/Clyde & oily cuttings & $\begin{array}{l}\text { } 950 \text { bbl } \\
\text { cuttings slurry; } \\
100 \text { bbl } \\
\text { seawater; } 450 \\
\text { bbl water-based } \\
\text { mud }\end{array}$ & $\begin{array}{l}\text { density: } 1.35- \\
1.42\end{array}$ & $\begin{array}{l}\text { cuttings ground in } \\
\text { vertical roller mill }\end{array}$ & & $\begin{array}{l}\text { this was an } \\
\text { experimental trial } \\
\text { to test the } \\
\text { feasibility of the } \\
\text { process }\end{array}$ & $\begin{array}{l}\text { cuttings from a well } \\
\text { side-track being } \\
\text { drilled are injected } \\
\text { into the annulus of a } \\
\text { nearby producing } \\
\text { well }\end{array}$ \\
\hline $\begin{array}{l}\text { North Sea/UK/Ninian } \\
\text { Central }\end{array}$ & drill cuttings & $42,327 \mathrm{bbl}$ & $\begin{array}{l}\text { seawater used } \\
\text { as fluid; } 94 \% \text { of } \\
\text { particles are } \\
<100 \text { microns }\end{array}$ & $\begin{array}{l}\text { grind slurry to } \\
>300 \text { micron } \\
\text { f average size; } \\
\text { polymer added to } \\
\text { improve viscosity }\end{array}$ & $\begin{array}{l}\text { injection did not always } \\
\text { keep up with drilling rate; } \\
\text { some inappropriate debris } \\
\text { added to waste pile; pulses } \\
\text { of solids could clog injection } \\
\text { zone }\end{array}$ & & $\begin{array}{l}\text { polymer was } \\
\text { biodegradable; then } \\
\text { needed to add } \\
\text { biocide to prevent } \\
\text { bacterial action in } \\
\text { injection zone }\end{array}$ \\
\hline North Sea/UK/Ninian South & drill cuttings & $48,383 \mathrm{bbl}$ & $\begin{array}{l}\text { seawater used } \\
\text { as fluid; } 94 \% \text { of } \\
\text { particles are } \\
<100 \text { microns }\end{array}$ & $\begin{array}{l}\text { grind slurry to } \\
>300 \text { micron } \\
\text { f average size; } \\
\text { polymer added to } \\
\text { improve viscosity }\end{array}$ & $\begin{array}{l}\text { injection did not always } \\
\text { keep up with drilling rate; } \\
\text { some inappropriate debris } \\
\text { added to waste pile; pulses } \\
\text { of solids could clog injection } \\
\text { zone }\end{array}$ & & $\begin{array}{l}\text { polymer was } \\
\text { biodegradable; then } \\
\text { needed to add } \\
\text { biocide to prevent } \\
\text { bacterial action in } \\
\text { injection zone }\end{array}$ \\
\hline Oklahoma/Mounds site & drill cuttings, used muds & $\begin{array}{l}\text { Wilcox - } 1,625 \\
\text { bbl slurry; Atoka } \\
1,790 \text { bbl slurry }\end{array}$ & $\begin{array}{l}\text { density } 1.8 \text { SG; } \\
\text { viscosity } 16 \mathrm{cp} \\
\text {-and } 72 \text { sec/qt; } \\
\text { solids } 10 \%\end{array}$ & not specified & & & $\begin{array}{l}\text { this was a planned } \\
\text { experiment by a } \\
\text { consortium of } \\
\text { operators, service } \\
\text { companies, and } \\
\text { researchers; the trial } \\
\text { was heavily } \\
\text { instrumented and } \\
\text { demonstrated that } \\
\text { intermittent injection } \\
\text { of small batches of } \\
\text { slurry would form a } \\
\text { "disposal domain" } \\
\text { rather than a single } \\
\text { large fracture } \\
\end{array}$ \\
\hline Russia/Sakhalin/Chayvo 6 & cuttings & $10,153 \mathrm{bbl}$ slurry & $9.1-10.6 \mathrm{lb} / \mathrm{gal}$ & & & & $\begin{array}{l}\text { limited data provided } \\
\text { for this job }\end{array}$ \\
\hline Texas onshore/\#1 & cuttings & 21,458 bbl slurry & & & & & $\begin{array}{l}\text { limited data provided } \\
\text { for this job }\end{array}$ \\
\hline Texas onshore/\#1 & cuttings & 12,765 bbl slurry & & & & & $\begin{array}{l}\text { limited data provided } \\
\text { for this job }\end{array}$ \\
\hline $\begin{array}{l}\text { Texas onshore/El } \\
\text { Campo/Krejci \#1 }\end{array}$ & cuttings & 9,880 bbl slurry & & & & & $\begin{array}{l}\text { limited data provided } \\
\text { for this job }\end{array}$ \\
\hline $\begin{array}{l}\text { Texas onshore/Fort } \\
\text { Stockton/Tomahawk\#1 }\end{array}$ & cuttings & $\begin{array}{l}\begin{array}{l}118,580 \mathrm{bbl} \\
\text { slurry }\end{array} \\
\end{array}$ & & & & & $\begin{array}{l}\text { limited data provided } \\
\text { for this job }\end{array}$ \\
\hline $\begin{array}{l}\text { Texas onshore/Jasper } \\
\text { County }\end{array}$ & $\begin{array}{l}\text { simulated waste slurry } \\
\text { made up of sand, } \\
\text { bentonite, and water }\end{array}$ & $\begin{array}{l}3 \text { million } \mathrm{lb} \text { sand, } \\
1 \text { million } \mathrm{lb} \\
\text { bentonite, and } \\
50,000 \text { bbl water }\end{array}$ & $\begin{array}{l}\text { bentonite slurry } \\
\text { of } 20-30 \mathrm{lb} / \mathrm{gal}\end{array}$ & & & $\begin{array}{l}\text { this was an } \\
\text { experimental trial } \\
\text { to test the } \\
\text { feasibility of the } \\
\text { process }\end{array}$ & $\begin{array}{l}\text { the trial was } \\
\text { monitored using } \\
\text { radioactive tracers, } \\
\text { temperature logs, } \\
\text { seismic monitoring, } \\
\text { and tiltmeters }\end{array}$ \\
\hline $\begin{array}{l}\text { Texas onshore/Zapata/Vela } \\
\text { Lopena\#1 }\end{array}$ & cuttings & 39,360 bbl slurry & & & & & $\begin{array}{l}\text { limited data provided } \\
\text { for this job }\end{array}$ \\
\hline Thailand/Satoon Bravo & cuttings & 4,880 bbl slurry & & & & & $\begin{array}{l}\text { limited data provided } \\
\text { for this job }\end{array}$ \\
\hline
\end{tabular}




\begin{tabular}{|c|c|c|c|c|c|c|c|c|c|c|c|c|}
\hline Site Location/Name & $\begin{array}{l}\text { Operator } \\
\text { Generating } \\
\text { Wastes }\end{array}$ & Source of Information & $\begin{array}{l}\text { Service } \\
\text { Company } \\
\text { Doing } \\
\text { Injection } \\
\end{array}$ & $\begin{array}{l}\text { Geology of Injection } \\
\text { Zone (type of rock, } \\
\text { porosity, permeability) }\end{array}$ & $\begin{array}{l}\text { Depth of } \\
\text { Injection Zone }\end{array}$ & $\begin{array}{l}\text { Depth of } \\
\text { Perforations/ } \\
\text { annular } \\
\text { Injection }\end{array}$ & $\begin{array}{l}\text { Geology and } \\
\text { Depth of } \\
\text { Confining } \\
\text { Layer } \\
\end{array}$ & $\begin{array}{l}\text { Other } \\
\text { Geological } \\
\text { Information }\end{array}$ & $\begin{array}{l}\text { Dates and Duration } \\
\text { of Injection }\end{array}$ & Injection Rate & $\begin{array}{l}\text { Injection } \\
\text { Pressure }\end{array}$ & $\begin{array}{l}\text { Type of } \\
\text { Injection }\end{array}$ \\
\hline Tunisia/Miskar/Well 1 & British Gas & Reddoch et al. $(1995,1996)$ & $\begin{array}{l}\text { Apollo } \\
\text { Services }\end{array}$ & $\begin{array}{l}\text { Salambo shale/claystone } \\
\text { formation }\end{array}$ & $\begin{array}{l}\text { not clearly } \\
\text { specified }\end{array}$ & 4,592' & not specified & & June - July 1993 & $1.5-3.0 \mathrm{bbl} / \mathrm{min}$ & $\begin{array}{l}900-2,700 \\
\text { psi }\end{array}$ & annular \\
\hline Tunisia/Miskar/Well 10 & British Gas & Apollo Services (2002) & $\begin{array}{l}\text { Apollo } \\
\text { Services }\end{array}$ & & & & & & & & & annular \\
\hline Tunisia/Miskar/Well 11 & British Gas & Apollo Services (2002) & $\begin{array}{l}\text { Apollo } \\
\text { Services }\end{array}$ & & & & & & & & & annular \\
\hline Tunisia/Miskar/Well 12 & British Gas & Apollo Services (2002) & $\begin{array}{l}\text { Apollo } \\
\text { Services }\end{array}$ & & & & & & & & & annular \\
\hline Tunisia/Miskar/Well 13 & British Gas & Apollo Services (2002) & $\begin{array}{l}\text { Apollo } \\
\text { Services }\end{array}$ & & & & & & & & & annular \\
\hline Tunisia/Miskar/Well 14 & British Gas & Apollo Services (2002) & $\begin{array}{l}\text { Apollo } \\
\text { Services }\end{array}$ & & & & & & & & & annular \\
\hline Tunisia/Miskar/Well 2 & British Gas & Reddoch et al. $(1995,1996)$ & $\begin{array}{l}\text { Apollo } \\
\text { Services }\end{array}$ & $\begin{array}{l}\text { Salambo shale/claystone } \\
\text { formation }\end{array}$ & $\begin{array}{l}\text { not clearly } \\
\text { specified }\end{array}$ & $4,887^{\prime}$ & not specified & & $7 / 93-10 / 93$ & $1.5-2.8 \mathrm{bbl} / \mathrm{min}$ & $\begin{array}{l}900-2,800 \\
\text { psi }\end{array}$ & annular \\
\hline Tunisia/Miskar/Well 3 & British Gas & Reddoch et al. $(1995,1996)$ & $\begin{array}{l}\text { Apollo } \\
\text { Services }\end{array}$ & $\begin{array}{l}\text { Salambo shale/claystone } \\
\text { formation }\end{array}$ & $\begin{array}{l}\text { not clearly } \\
\text { specified }\end{array}$ & 4,941' & not specified & & $10 / 93-9 / 94$ & $1.0-3.5 \mathrm{bbl} / \mathrm{min}$ & $\begin{array}{l}400-2,900 \\
\text { psi }\end{array}$ & annular \\
\hline Tunisia/Miskar/Well 4 & British Gas & Apollo Services (2002) & $\begin{array}{l}\text { Apollo } \\
\text { Services }\end{array}$ & & & & & & & & & annular \\
\hline Tunisia/Miskar/Well 5 & British Gas & Apollo Services (2002) & $\begin{array}{l}\text { Apollo } \\
\text { Services }\end{array}$ & & & & & & & & & annular \\
\hline Tunisia/Miskar/Well 6 & British Gas & Apollo Services (2002) & $\begin{array}{l}\text { Apollo } \\
\text { Services }\end{array}$ & & & & & & & & & annular \\
\hline Tunisia/Miskar/Well 7 & British Gas & Apollo Services (2002) & $\begin{array}{l}\text { Apollo } \\
\text { Services }\end{array}$ & & & & & & & & & annular \\
\hline Tunisia/Miskar/Well 8 & British Gas & Apollo Services (2002) & $\begin{array}{l}\text { Apollo } \\
\text { Services }\end{array}$ & & & & & & & & & annular \\
\hline Tunisia/Miskar/Well 9 & British Gas & Apollo Services (2002) & $\begin{array}{l}\text { Apollo } \\
\text { Services }\end{array}$ & & & & & & & & & annular \\
\hline $\begin{array}{l}\text { UK onshore/Wytch Farm/ } \\
\text { 2B-10 }\end{array}$ & $\mathrm{BP}$ & $\begin{array}{l}\text { Wood et al. (1995); Hagan et } \\
\text { al. (2002) }\end{array}$ & & $\begin{array}{l}\text { Sherwood sandstone } \\
\text { (producing formation) }\end{array}$ & $\sim 5,100^{\prime}-5,600^{\prime}$ & $\sim 5,300^{\prime}$ & $\begin{array}{l}\text { Mercia } \\
\text { mudstone from } \\
\sim 4,000^{\prime}-5,100^{\prime}\end{array}$ & $\begin{array}{l}\text { another } \\
\text { producing } \\
\text { reservoir is } \\
\text { located in the } \\
\text { Bridgeport sands } \\
\text { at 3,000'-3,200' }\end{array}$ & $\begin{array}{l}\text { 4/93 - 10/93; injection } \\
\text { done in batches of } \\
150-400 \text { bbl, followed } \\
\text { by a flush of } 120-150 \\
\text { bbl of water }\end{array}$ & $\begin{array}{l}4 \mathrm{bbl} / \mathrm{min} \text { for } \\
\text { slurry; } 5 \mathrm{bbl} / \mathrm{min} \\
\text { for seawater } \\
\text { flush; normal } \\
\text { produced water } \\
\text { injection } 4-9 \\
\text { bbl/min }\end{array}$ & $\begin{array}{l}2,000 \mathrm{psi} \\
\text { max. }\end{array}$ & $\begin{array}{l}\text { tubing and } \\
\text { packer } \\
\text { through } \\
\text { produced } \\
\text { water } \\
\text { injection } \\
\text { well } \\
\end{array}$ \\
\hline Venezuela/PAC 68 & $\mathrm{BP}$ & Apollo Services (2002) & $\begin{array}{l}\text { Apollo } \\
\text { Services }\end{array}$ & & & & & & & & & annular \\
\hline
\end{tabular}




\begin{tabular}{|c|c|c|c|c|c|c|c|}
\hline Site Location/Name & Type of Waste Injected & $\begin{array}{l}\text { Volume of } \\
\text { Material } \\
\text { Injected }\end{array}$ & $\begin{array}{l}\text { Slurry } \\
\text { Properties } \\
\text { (fluid, } \\
\text { density) } \\
\end{array}$ & $\begin{array}{l}\text { Pre-Injection } \\
\text { Processing/ } \\
\text { Treatment }\end{array}$ & Problems Experienced & Costs & Other Comments \\
\hline Tunisia/Miskar/Well 1 & oil cuttings & 10,409 bbl slurry & $\begin{array}{l}\text { density } 10.2- \\
12.4 \mathrm{lb} / \mathrm{gal} ; \\
\text { seawater used } \\
\text { as fluid }\end{array}$ & $\begin{array}{l}\text { centrifugal pump } \\
\text { used to break } \\
\text { solids into smaller } \\
\text { particles }\end{array}$ & $\begin{array}{l}\text { injection pressure rose high } \\
\text { on first two wells; increased } \\
\text { burst strength on casing in } \\
\text { third well }\end{array}$ & & $\begin{array}{l}\text { used continuous } \\
\text { injection and } \\
\text { discontinued water } \\
\text { sweeps }\end{array}$ \\
\hline Tunisia/Miskar/Well 10 & cuttings & $12,973 \mathrm{bbl}$ slurry & & & & & $\begin{array}{l}\text { limited data provided } \\
\text { for this job }\end{array}$ \\
\hline Tunisia/Miskar/Well 11 & cuttings & 11,752 bbl slurry & & & & & $\begin{array}{l}\text { limited data provided } \\
\text { for this job }\end{array}$ \\
\hline Tunisia/Miskar/Well 12 & cuttings & 11,936 bbl slurry & & & & & $\begin{array}{l}\text { limited data provided } \\
\text { for this job }\end{array}$ \\
\hline Tunisia/Miskar/Well 13 & cuttings & 12,279 bbl slurry & & & & & $\begin{array}{l}\text { limited data provided } \\
\text { for this job }\end{array}$ \\
\hline Tunisia/Miskar/Well 14 & cuttings & 10,422 bbl slurry & & & & & $\begin{array}{l}\text { limited data provided } \\
\text { for this job }\end{array}$ \\
\hline Tunisia/Miskar/Well 2 & oil cuttings & 8,940 bbl slurry & $\begin{array}{l}\text { density } 10.0- \\
12.6 \mathrm{lb} / \mathrm{gal} ; \\
\text { seawater used } \\
\text { as fluid }\end{array}$ & $\begin{array}{l}\text { centrifugal pump } \\
\text { used to break } \\
\text { solids into smaller } \\
\text { particles }\end{array}$ & $\begin{array}{l}\text { injection pressure rose high } \\
\text { on first two wells; increased } \\
\text { burst strength on casing in } \\
\text { third well }\end{array}$ & & $\begin{array}{l}\text { used continuous } \\
\text { injection and } \\
\text { discontinued water } \\
\text { sweeps }\end{array}$ \\
\hline Tunisia/Miskar/Well 3 & oil cuttings & $63,510 \mathrm{bbl}$ slurry & $\begin{array}{l}\text { density 10.0- } \\
13.3 \mathrm{lb} / \mathrm{gal} ; \\
\text { seawater used } \\
\text { as fluid } \\
\end{array}$ & $\begin{array}{l}\text { centrifugal pump } \\
\text { used to break } \\
\text { solids into smaller } \\
\text { particles }\end{array}$ & $\begin{array}{l}\text { injection pressure rose high } \\
\text { on first two wells; increased } \\
\text { burst strength on casing in } \\
\text { third well }\end{array}$ & & $\begin{array}{l}\text { used continuous } \\
\text { injection and } \\
\text { discontinued water } \\
\text { sweeps }\end{array}$ \\
\hline Tunisia/Miskar/Well 4 & cuttings & 9,478 bbl slurry & & & & & $\begin{array}{l}\text { limited data provided } \\
\text { for this job }\end{array}$ \\
\hline Tunisia/Miskar/Well 5 & cuttings & $18,773 \mathrm{bbl}$ slurry & & & & & $\begin{array}{l}\text { limited data provided } \\
\text { for this job }\end{array}$ \\
\hline Tunisia/Miskar/Well 6 & cuttings & 11,022 bbl slurry & & & & & $\begin{array}{l}\text { limited data provided } \\
\text { for this job }\end{array}$ \\
\hline Tunisia/Miskar/Well 7 & cuttings & 14,960 bbl slurry & & & & & $\begin{array}{l}\text { limited data provided } \\
\text { for this job }\end{array}$ \\
\hline Tunisia/Miskar/Well 8 & cuttings & 9,972 bbl slurry & & & & & $\begin{array}{l}\text { limited data provided } \\
\text { for this job }\end{array}$ \\
\hline Tunisia/Miskar/Well 9 & cuttings & 10,435 bbl slurry & & & & & $\begin{array}{l}\text { limited data provided } \\
\text { for this job }\end{array}$ \\
\hline $\begin{array}{l}\text { UK onshore/Wytch Farm/ } \\
\text { 2B-10 }\end{array}$ & $\begin{array}{l}\text { oily cuttings, mud, } \\
\text { contaminated rainwater, } \\
\text { wastewater, and seawater } \\
\text { used for completion and } \\
\text { testing of wells }\end{array}$ & $\begin{array}{l}>190,000 \mathrm{bbl} \\
\text { slurry }\end{array}$ & $\begin{array}{l}\text { density 1.3-1.5 } \\
\text { SG; target } \\
\text { viscosity } 50- \\
110 \text { sec/qt; } \\
\text { seawater used } \\
\text { as fluid }\end{array}$ & $\begin{array}{l}\text { mixed in tank then } \\
\text { passed through } \\
\text { grinding mills }\end{array}$ & $\begin{array}{l}\text { in early days of injection, } \\
\text { well got plugged by solids } \\
\text { settling in well bore; } \\
\text { corrected by controlling } \\
\text { viscosity more closely }\end{array}$ & $\begin{array}{l}\text { reduced waste } \\
\text { disposal costs } \\
\text { from, } \$ 600,000 \text { to } \\
\$ 270,000 \text { per } \\
\text { well }\end{array}$ & $\begin{array}{l}\text { the injection wells } \\
\text { are active produced } \\
\text { water injectors to the } \\
\text { producing formation; } \\
\text { in between batches } \\
\text { of slurry injection, the } \\
\text { o wells return to } \\
\text { service as water } \\
\text { injectors }\end{array}$ \\
\hline Venezuela/PAC 68 & cuttings & 65,000 bbl slurry & & & & & $\begin{array}{l}\text { limited data provided } \\
\text { for this job }\end{array}$ \\
\hline
\end{tabular}

